\title{
NTP TECHNICAL REPORT ON THE TOXICITY STUDIES OF \\ OCTAHYDRO-TETRAMETHYL- \\ NAPHTHALENYL-ETHANONE \\ (OTNE) ADMINISTERED \\ Dermally to F344/NTac Rats \\ AND B6C3Fl/N MICE
}

NTP TOX 92

JUNE 2016 


\section{NTP Technical Report on the Toxicity Studies of Octahydro-tetramethyl-naphthalenyl-ethanone (OTNE) Administered Dermally to F344/NTac Rats and B6C3F1/N Mice}

Toxicity Report 92

June 2016

National Toxicology Program

Public Health Service

U.S. Department of Health and Human Services

ISSN: 2378-8992

Research Triangle Park, North Carolina, USA 


\section{Foreword}

The National Toxicology Program (NTP) is an interagency program within the Public Health Service (PHS) of the Department of Health and Human Services (HHS) and is headquartered at the National Institute of Environmental Health Sciences of the National Institutes of Health (NIEHS/NIH). Three agencies contribute resources to the program: NIEHS/NIH, the National Institute for Occupational Safety and Health of the Centers for Disease Control and Prevention (NIOSH/CDC), and the National Center for Toxicological Research of the Food and Drug Administration (NCTR/FDA). Established in 1978, NTP is charged with coordinating toxicological testing activities, strengthening the science base in toxicology, developing and validating improved testing methods, and providing information about potentially toxic substances to health regulatory and research agencies, scientific and medical communities, and the public.

The Toxicity Study Report series began in 1991. The studies described in the Toxicity Study Report series are designed and conducted to characterize and evaluate the toxicologic potential of selected substances in laboratory animals (usually two species, rats and mice). Substances selected for NTP toxicity studies are chosen primarily on the basis of human exposure, level of production, and chemical structure. The interpretive conclusions presented in the Toxicity Study Reports are based only on the results of these NTP studies. Extrapolation of these results to other species, including characterization of hazards and risks to humans, requires analyses beyond the intent of these reports. Selection per se is not an indicator of a substance's toxic potential. NTP conducts its studies in compliance with its laboratory health and safety guidelines and FDA Good Laboratory Practice Regulations and must meet or exceed all applicable federal, state, and local health and safety regulations. Animal care and use are in accordance with the Public Health Service Policy on Humane Care and Use of Animals. Studies are subjected to retrospective quality assurance audits before being presented for public review.

NTP Toxicity Study Reports are indexed in the National Center for Biotechnology Informtion (NCBI) Bookshelf and are available free of charge electronically on the NTP website (http://ntp.niehs.nih.gov). Toxicity data are available through NTP's Chemical Effects in Biological Systems (CEBS) database: https://www.niehs.nih.gov/research/resources/databases/index.cfm. 


\section{Table of Contents}



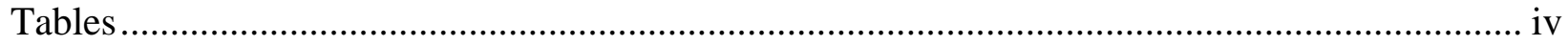

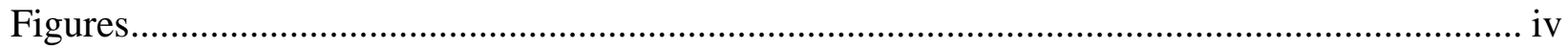

About This Report........................................................................................................... vi

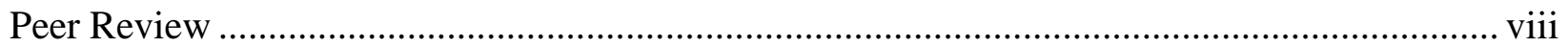

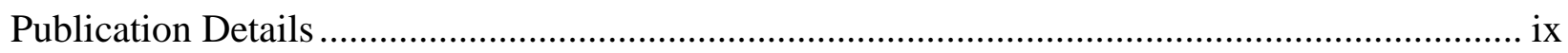

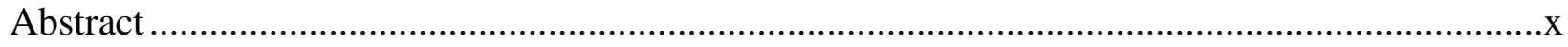

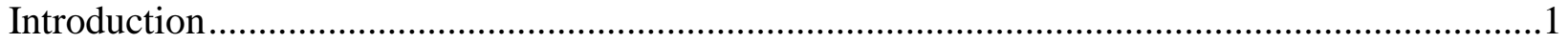

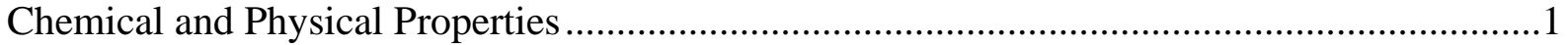

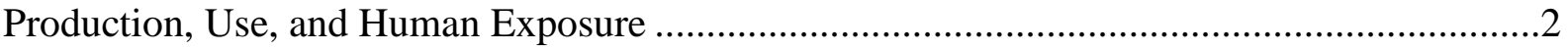

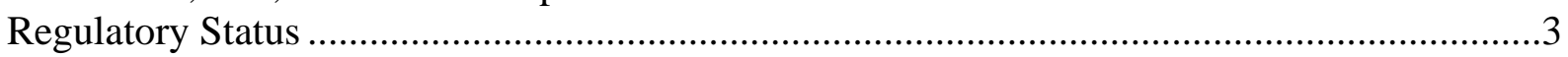

Absorption, Distribution, Metabolism, Excretion, and Toxicokinetics ......................................

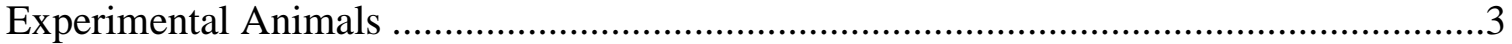

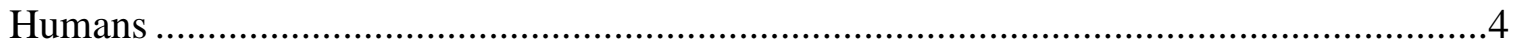

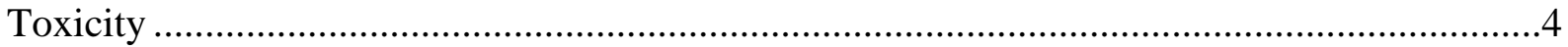

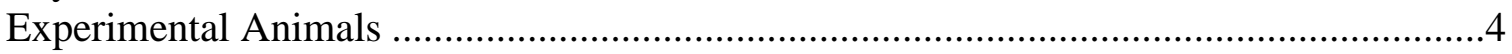



Reproductive and Developmental Toxicity .......................................................................6

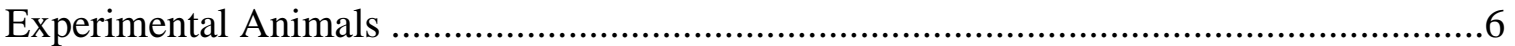

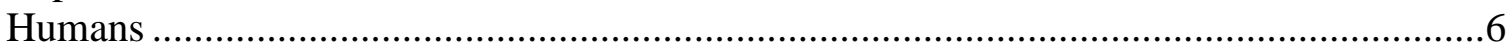

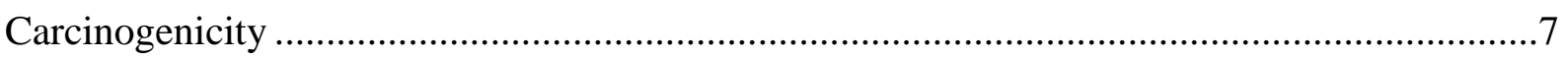

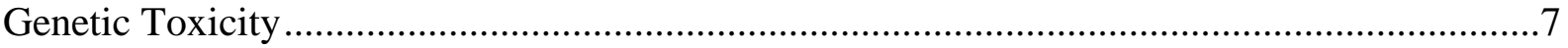

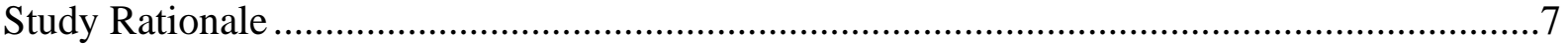

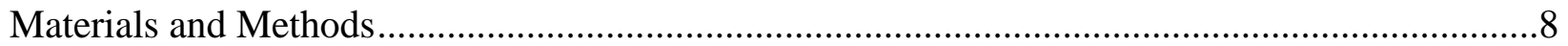

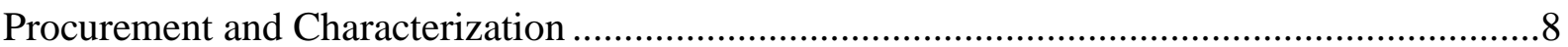

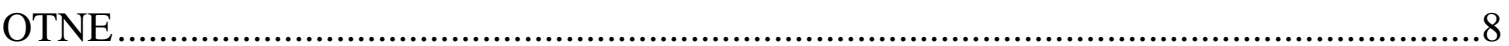

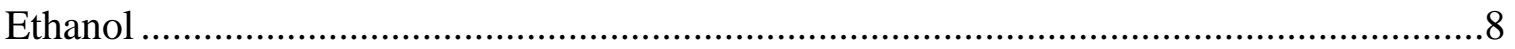

Preparation and Analysis of Dose Formulations.................................................................

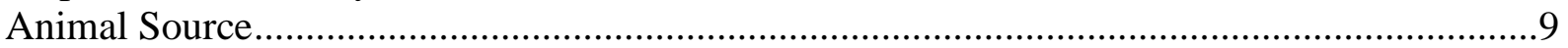



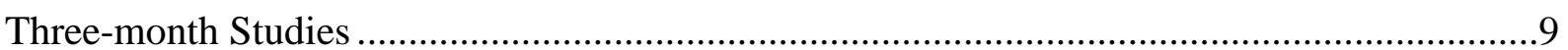

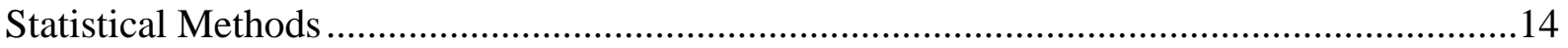

Calculation and Analysis of Lesion Incidences .........................................................14

Analysis of Continuous Variables ..............................................................................

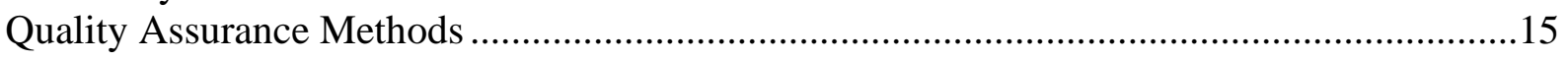

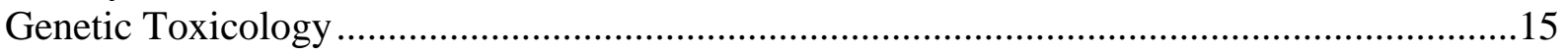

Bacterial Mutagenicity Test Protocol ...........................................................................15

In Vivo Peripheral Blood Micronucleus Test Protocol in Rats and Mice ..........................15

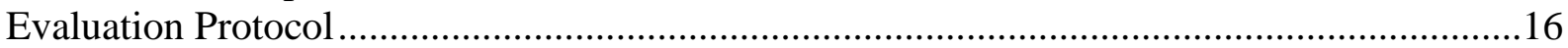




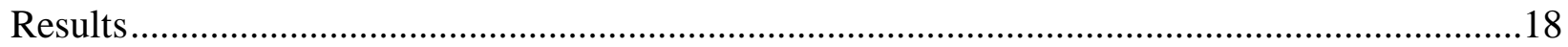

Three-month Study in Rats .....................................................................................18

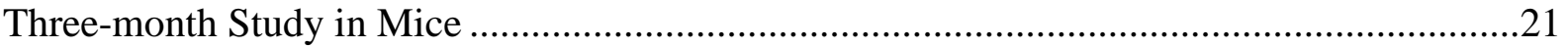

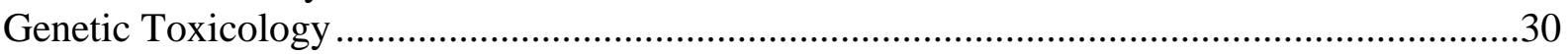

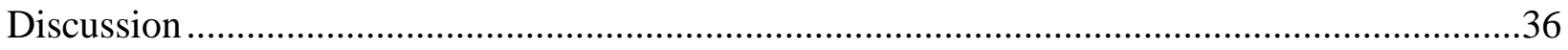

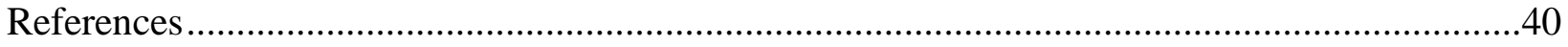

Appendix A. Summary of Lesions in Rats and Mice …….................................................. A-1

Appendix B. Clinical Pathology and Liver Toxicity Results ......................................................

Appendix C. Organ Weights and Organ Weight to Body-Weight Ratios ......................................

Appendix D. Reproductive Tissue Evaluations and Estrous Cycle Characterization ................ D-1

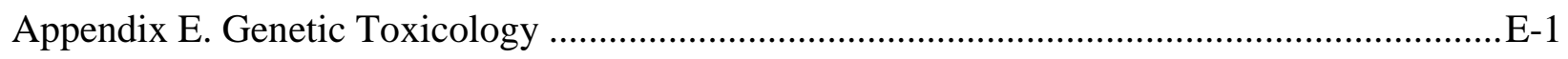

Appendix F. Chemical Characterization and Dose Formulation Studies ....................................F-1

Appendix G. Ingredients, Nutrient Composition, and Contaminant Levels in NTP-2000 Rat and Mouse Ration .................................................................................

Appendix H. Sentinel Animal Program .......................................................................... H-1

\section{Tables}

Table 1. Physical Properties of Primary OTNE Isomers ..............................................................

Table 2. Experimental Design and Materials and Methods in the Three-month Dermal

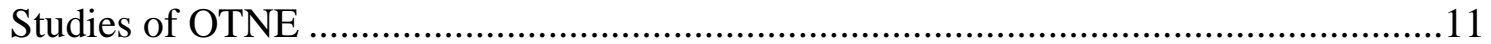

Table 3. Survival and Body Weights of Rats in the Three-month Dermal Study of OTNE .........18

Table 4. Liver Weights and Liver-Weight-to-Body-Weight Ratios for Rats in the Threemonth Dermal Study of OTNE................................................................................20

Table 5. Incidences of Nonneoplastic Lesions of the Skin (Site of Application) in Rats in the Three-month Dermal Study of OTNE ……………............................................21

Table 6. Survival and Body Weights of Mice in the Three-month Dermal Study of OTNE ........22

Table 7. Liver Weights and Liver-Weight-to-Body-Weight Ratios for Mice in the Threemonth Dermal Study of OTNE.............................................................................25

Table 8. Summary of Reproductive Tissue Evaluations for Male Mice in the Three-month Dermal Study of OTNE.

Table 9. Estrous Cycle Characterization for Female Mice in the Three-month Dermal

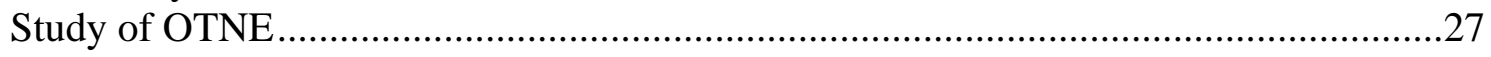

Table 10. Incidences of Selected Nonneoplastic Lesions in Mice in the Three-month Dermal Study of OTNE

\section{Figures}

Figure 1. Octahydro-tetramethyl-naphthalenyl-ethanone (OTNE) (CASRN 54464-57-2 ( $\beta$-isomer), 68155-67-9 ( $\alpha$-isomer), 68155-66-8 ( $\gamma$-isomer); Chemical Formula: $\mathrm{C}_{16} \mathrm{H}_{26} \mathrm{O}$; Molecular Weight: 234.38) 
Figure 2. Growth Curves for Rats Exposed to OTNE by Dermal Application for Three Months

Figure 3. Growth Curves for Mice Exposed to OTNE by Dermal Application for Three

Months

Figure 4. Normal Epidermis (Arrows) in the Skin (Site of Application) of a Vehicle Control Female F344/NTac Rat in the Three Month Dermal Study of OTNE (H\&E).

Figure 5. Higher Magnification of Figure 4 (H\&E)

Figure 6. Mild Hyperplasia (Long Arrows) and Hyperkeratosis (Short Arrows) in the Skin (Site of Application) of a Female F344/NTac Rat Dermally Administered $100 \%$ OTNE for Three Months (H\&E)

Figure 7. Higher Magnification of Figure 6 (H\&E)

Figure 8. Normal Epidermis (Arrows) in the Skin (Site of Application) of a Vehicle Control Female B6C3F1/N Mouse in the Three-month Dermal Study of OTNE (H\&E).

Figure 9. Higher Magnification of Figure $8(\mathrm{H} \& \mathrm{E})$

Figure 10. Moderate Hyperplasia (Long Arrows) and Mild Hyperkeratosis (Short Arrows) in the Skin (Site of Application) of a Female B6C3F1/N Mouse Dermally Administered 6.25\% OTNE for Three Months (H\&E)

Figure 11. Higher Magnification of Figure 10 (H\&E)

Figure 12. Suppurative Inflammation in the Skin (Site of Application) of a Female B6C3F1/N Mouse Dermally Administered 100\% OTNE for Three Months $(\mathrm{H} \& \mathrm{E})$

Figure 13. Higher Magnification of Figure 12 (H\&E)

This report has been reformatted to meet new NTP publishing requirements; its content has not changed. 


\section{About This Report}

National Toxicology Program ${ }^{1}$

${ }^{1}$ Division of the National Toxicology Program, National Institute of Environmental Health

Sciences, Research Triangle Park, North Carolina, USA

\section{Collaborators}

K.R. Ryan, R.A. Herbert, E.T. Adams, C.R. Blystone, M.C. Cora, P.M. Foster, D.R. Germolec, C.D. Hébert, K.R. Hobbie, M.J. Hooth, A.P. King-Herbert, G.E. Kissling, D.E. Malarkey, B.S. McIntyre, E. Mylchreest, M. Paranjpe, G.E. Simmons, S.L. Smith-Roe, M.D. Stout, G.S.

Travlos, R.W. Tyl, M.K. Vallant, S. Waidyanatha, N.J. Walker, M.L. Wenk, K.L. Witt

Division of the National Toxicology Program, National Institute of Environmental Health Sciences, Research Triangle Park, North Carolina, USA

Evaluated and interpreted results and reported findings

K.R. Ryan, Ph.D., Study Scientist

R.A. Herbert, D.V.M., Ph.D., Study Pathologist

C.R. Blystone, Ph.D.

M.C. Cora, D.V.M.

P.M. Foster, Ph.D.

D.R. Germolec, Ph.D.

M.J. Hooth, Ph.D.

A.P. King-Herbert, D.V.M.

G.E. Kissling, Ph.D.

D.E. Malarkey, D.V.M., Ph.D.

B.S. McIntyre, Ph.D.

S.L. Smith-Roe, Ph.D.

M.D. Stout, Ph.D.

G.S. Travlos, D.V.M.

M.K. Vallant, M.S., MT

S. Waidyanatha, Ph.D.

N.J. Walker, Ph.D.

K.L. Witt, M.S.

BioReliance Corporation, Rockville, Maryland, USA

Conducted studies and evaluated pathology findings

M.L. Wenk, Ph.D., Principal Investigator

M. Paranjpe, D.V.M., Ph.D.

Experimental Pathology Laboratories, Inc., Research Triangle Park, North Carolina, USA

Conducted pathology review

E.T. Adams, D.V.M., Ph.D.

ILS, Inc., Research Triangle Park, North Carolina, USA

Coordinated NTP Pathology Working Group (March 10, 2011)

K.R. Hobbie, D.V.M., Ph.D. 
RTI International, Research Triangle Park, North Carolina, USA

Provided andrology analyses

R.W. Tyl, Ph.D., Principal Investigator

Southern Research Institute, Birmingham, Alabama, USA

Provided vaginal cytology analyses

C.D. Hébert, Ph.D., Principal Investigator

E. Mylchreest, Ph.D.

\section{Contributors}

NTP Pathology Working Group, National Institute of Environmental Health Sciences, Research Triangle Park, North Carolina, USA

Participated in NTP Pathology Working Group (March 10, 2011)

G.P. Flake, M.D., National Toxicology Program

R.A. Herbert, D.V.M., Ph.D., National Toxicology Program

M.J. Hoenerhoff, D.V.M., Ph.D., National Toxicology Program

Experimental Pathology Laboratories, Inc., Research Triangle Park, North Carolina, USA

Supervised pathology review

M.H. Hamlin, II, D.V.M., Principal Investigator

Dynamac Corporation, Research Triangle Park, North Carolina, USA

Prepared quality assessment audits

S. Brecher, Ph.D., Principal Investigator

S. Iyer, B.S.

V.S. Tharakan, D.V.M.

Social \& Scientific Systems, Inc., Research Triangle Park, North Carolina, USA

Provided statistical analyses

M.V. Smith, Ph.D., Principal Investigator

L.J. Betz, M.S.

S.F. Harris, B.S.

Biotechnical Services, Inc., Little Rock, Arkansas, USA

Prepared Toxicity Study Report

S.R. Gunnels, M.A., Principal Investigator

L.M. Harper, B.S.

D.C. Serbus, Ph.D.

G.E. Simmons, M.A. 


\section{Peer Review}

The draft NTP Technical Report on the Toxicity Studies of Octahydro-tetramethyl-naphthalenylethanone (OTNE) Administered Dermally to F344/NTac Rats and B6C3F1/N Mice was evaluated by the reviewers listed below. These reviewers served as independent scientists, not as representatives of any institution, company, or governmental agency. In this capacity, reviewers determined if the design and conditions of these NTP studies were appropriate and ensured that this Toxicity Study Report presented the experimental results and conclusions fully and clearly.

\section{Peer Reviewers}

\section{Laura A. Hanson, Ph.D.}

Director, Molecular Mechanisms of Carcinogenesis Program

Creighton University School of Medicine

Omaha, Nebraska, USA

Greg Erexson, Ph.D.

Principal Occupational and Environmental Toxicologist

AbbVie

North Chicago, Illinois, USA 
OTNE, NTP TOX 92

\section{Publication Details}

Publisher: National Toxicology Program

Publishing Location: Research Triangle Park, NC

ISSN: $2378-8992$

DOI: https://doi.org/10.22427/NTP-TOX-92

Report Series: NTP Toxicity Report Series

Report Series Number: 92

Official citation: National Toxicology Program (NTP). 2016. NTP technical report on the toxicity studies of octahydro-tetramethyl-naphthalenyl-ethanone (OTNE) administered dermally to F344/NTac rats and B6C3F1/N mice. Research Triangle Park, NC: National Toxicology

Program. Toxicity Report 92. 


\section{Abstract}

Octahydro-tetramethyl-naphthalenyl-ethanone (OTNE) is a fragrance ingredient that is formed as a mixture of isomers with a basic unsaturated alkyl cyclic ketone structure. The main isomer is 1 -(1,2,3,4,5,6,7,8-octahydro-2,3,8,8-tetramethyl-2-naphthalenyl)ethanone ( $\beta$-isomer). Two other predominant isomers within the mixture are 1-(1,2,3,4,6,7,8,8a-octahydro-2,3,8,8-tetramethyl-2naphthalenyl)ethanone ( $\alpha$-isomer) and 1-(1,2,3,5,6,7,8,8a-octahydro-2,3,8,8-tetramethyl-2naphthalenyl)ethanone ( $\gamma$-isomer). OTNE is used as a perfume ingredient in soap, shampoo, cologne, liquid detergent compounds, and malodor-reducing compounds. Male and female F344/NTac rats and B6C3F1/N mice were administered OTNE (greater than 92.3\% pure with respect to the 3 prominent isomers) dermally for 3 months. Genetic toxicology studies were conducted in Salmonella typhimurium, Escherichia coli, and rat and mouse peripheral blood erythrocytes.

Groups of 10 male and 10 female core study rats and mice received no treatment (untreated control) or dermal application of OTNE in 95\% aqueous ethanol at concentrations of $0 \%$ (vehicle control), $6.25 \%, 12.5 \%, 25 \%, 50 \%$, or $100 \%$ (neat) 5 days per week for 3 months. Animals in the $100 \%$ OTNE groups were compared to untreated controls, and the remaining dosed groups were compared to the vehicle controls. Groups of 10 male and 10 female special study rats received the same doses for 22 days. Formulations were administered at a volume of $0.5 \mathrm{~mL} / \mathrm{kg}$ body weight (rats) or $2.0 \mathrm{~mL} / \mathrm{kg}$ body weight (mice), which resulted in mice receiving higher doses $(\mathrm{mg} / \mathrm{kg})$ of OTNE than rats. Dose ranges for rats and mice were estimated as 31.25 to $500 \mathrm{mg}$ OTNE/ $\mathrm{kg}$ body weight and 125 to $2,000 \mathrm{mg} / \mathrm{kg}$, respectively. All rats and mice survived to the end of the study. Final mean body weights and body weight gains of dosed male and female rats were similar to those of the respective control groups with the exception of the $100 \%$ OTNE male rats, which had a statistically significant decrease in mean body weight gain compared to the untreated controls. The final mean body weights of $6.25 \%, 25 \%$, and $50 \%$ OTNE male mice and mean body weight gains of $6.25 \%$ and $25 \%$ OTNE male mice were significantly less than those of the vehicle control group; those of $100 \%$ OTNE male mice were significantly less than those of the untreated controls. Body weights of female mice were unaffected by OTNE treatment. In rats, alanine aminotransferase activities were significantly decreased in all dosed groups of males and in 25\% to $100 \%$ OTNE females; furthermore, alkaline phosphatase activities were significantly decreased in $100 \%$ OTNE males and females. Erythrocyte counts, hemoglobin concentrations, and hematocrit values were significantly decreased in male mice administered $25 \%$ OTNE or greater and in $100 \%$ OTNE female mice. OTNE exposure via dermal application exhibited the potential to be a reproductive toxicant in male and female B6C3F1/N mice.

In rats, relative liver weights of 50\% OTNE males and the absolute and relative liver weights of $100 \%$ OTNE males and 50\% and 100\% OTNE females were significantly greater than those in the respective control groups. In male and female mice, the absolute and relative liver weights of all dosed groups were significantly greater than those of the respective control groups with the exception of the absolute liver weight in $6.25 \%$ OTNE males. In addition, the relative kidney weights of $100 \%$ OTNE male and female rats were significantly increased, and the absolute thymus weights of $100 \%$ OTNE male and female mice and relative thymus weight of $100 \%$ OTNE female mice were significantly decreased compared to their respective control groups. 
Histologically, the incidence of mild centrilobular hypertrophy was significantly increased in male mice treated with $100 \%$ OTNE compared to the untreated control group.

In male and female rats administered $12.5 \%$ to $50 \%$ OTNE, the incidences of minimal to mild hyperplasia and hyperkeratosis (except in $12.5 \%$ OTNE males) at the site of application were significantly greater than those in the vehicle control groups; the incidences of these lesions in $100 \%$ OTNE males and females were significantly greater than the untreated control incidences.

In the skin of mice at the site of application, the incidences of minimal to moderate hyperplasia and chronic active inflammation were significantly increased in all dosed groups. The incidences of minimal to mild hyperkeratosis were significantly increased in males administered $12.5 \%$ OTNE or greater and in all dosed groups of females. The incidences of fibrosis were significantly increased in all dosed groups of males except the $12.5 \%$ OTNE group, and in females administered $12.5 \%$ OTNE or greater. The incidences of epidermis suppurative inflammation were significantly increased in 100\% OTNE males and in females administered $25 \%$ OTNE or greater. The incidences of hair follicle hyperplasia were significantly increased in males administered $50 \%$ or $100 \%$ OTNE and females administered $25 \%$ OTNE or greater. Furthermore, the incidences of minimal to mild nonneoplastic lesions noted in the skin adjacent to the site of application of male and female mice were considered secondary to the spread of the test material from the site of application rather than a systemic effect. Incidences of hyperplasia, chronic active inflammation, hyperkeratosis, and fibrosis in the skin adjacent to the site of application were significantly increased in 100\% OTNE-treated male and female mice.

OTNE was not mutagenic in Salmonella typhimurium strains TA98, TA100, or TA102, or in Escherichia coli strain WP2 uvrA/pKM101, with or without exogenous metabolic activation. In vivo, increases in micronucleated reticulocytes and mature erythrocytes were observed in female $\mathrm{B} 6 \mathrm{C} 3 \mathrm{~F} 1 / \mathrm{N}$ mice and in mature erythrocytes in male $\mathrm{B} 6 \mathrm{C} 3 \mathrm{~F} 1 / \mathrm{N}$ mice following dermal application of OTNE for 3 months. In contrast, no increases in micronucleated reticulocytes were seen in male or female F344/NTac rats following dermal exposure to OTNE for 3 months. In rats, only the very young reticulocyte population is assessed in peripheral blood for micronucleus frequency due to rapid removal of damaged reticulocytes from circulation by the rat spleen.

Under the conditions of these 3-month dermal studies, the major target in F344/NTac rats and B6C3F1/N mice was the skin, site of application. Lesions were more prominent in mice than rats based upon the incidences and severities of hyperplasia, hyperkeratosis, and inflammation of the skin, site of application. Additionally, hepatic lesions were apparent in mice, but not rats. OTNE exhibited the potential to be a reproductive toxicant in male and female mice. These species differences could be attributed to dose, because mice received approximately four times the amount of OTNE on a $\mathrm{mg} / \mathrm{kg}$ body weight basis than rats. In male and female rats, the lowestobserved-effect level (LOEL) of 12.5\% OTNE was based on the increased incidences of skin lesions. In male and female mice, the LOEL was 6.25\% OTNE, based on the increased incidences of skin lesions and increased relative liver weights.

Synonyms: 1' ' $^{\prime}, 3^{\prime}, 4^{\prime}, 5^{\prime}, 6^{\prime}, 7^{\prime}, 8^{\prime}$-Octahydro-2', 3', $8^{\prime}, 8^{\prime}$-tetramethyl-2' -acetonaphthone; 1,2,3,4,5,6,7,8-octahydro-2,3,8,8-tetramethyl-2-acetonaphthone; 1-(1,2,3,4,5,6,7,8-octahydro2,3,8,8-tetramethyl-2-naphthalenyl)ethanone; 1-(1,2,3,4,6,7,8,8a-octahydro-2,3,8,8-tetramethyl2-naphthyl)ethan-1-one; 1-(1,2,3,5,6,7,8,8a-octahydro-2,3,8,8-tetramethyl-2-naphthyl)ethan-1one; 1-(1,2,3,4,5,6,7,8-octahydro-2,3,5,5-tetramethyl-2-naphthyl)ethan-1-one 
Trade Names: Amberonne, Ambralux, Boisvelone, Iso Ambois Super, Iso E Super ${ }^{\circledR}$, Isocyclemone, Isocyclemone $\mathrm{E}$, Orbitone

Findings Considered to be Toxicologically Relevant in Rats and Mice Dermally Exposed to OTNE for Three Months

\begin{tabular}{|c|c|c|c|c|}
\hline & $\begin{array}{c}\text { Male F344/NTac } \\
\text { Rats }\end{array}$ & $\begin{array}{c}\text { Female F344/NTac } \\
\text { Rats }\end{array}$ & $\begin{array}{c}\text { Male B6C3F1/N } \\
\text { Mice }\end{array}$ & $\begin{array}{c}\text { Female B6C3F1/N } \\
\text { Mice }\end{array}$ \\
\hline $\begin{array}{l}\text { Concentrations in } \\
95 \% \text { ethanol }\end{array}$ & $\begin{array}{l}\text { Untreated control, } \\
0 \%, 6.25 \%, 12.5 \% \text {, } \\
25 \%, 50 \% \text {, and } 100 \% \\
\text { OTNE }\end{array}$ & $\begin{array}{l}\text { Untreated control, } \\
0 \%, 6.25 \%, 12.5 \% \text {, } \\
25 \%, 50 \% \text {, and } 100 \% \\
\text { OTNE }\end{array}$ & $\begin{array}{l}\text { Untreated control, } \\
0 \%, 6.25 \%, 12.5 \% \text {, } \\
25 \%, 50 \% \text {, and } 100 \% \\
\text { OTNE }\end{array}$ & $\begin{array}{l}\text { Untreated control, } \\
0 \%, 6.25 \%, 12.5 \% \text {, } \\
25 \%, 50 \% \text {, and } 100 \% \\
\text { OTNE }\end{array}$ \\
\hline Survival rates & $\begin{array}{l}10 / 10,10 / 10,10 / 10 \\
10 / 10,10 / 10,10 / 10 \\
10 / 10\end{array}$ & $\begin{array}{l}10 / 10,10 / 10,10 / 10 \\
10 / 10,10 / 10,10 / 10 \\
10 / 10\end{array}$ & $\begin{array}{l}10 / 10,10 / 10,10 / 10 \\
10 / 10,10 / 10,10 / 10 \\
10 / 10\end{array}$ & $\begin{array}{l}10 / 10,10 / 10,10 / 10 \\
10 / 10,10 / 10,10 / 10 \\
10 / 10\end{array}$ \\
\hline Body weights & $\begin{array}{l}\text { Dosed groups similar } \\
\text { to the respective } \\
\text { control groups }\end{array}$ & $\begin{array}{l}\text { Dosed groups similar } \\
\text { to the respective } \\
\text { control groups }\end{array}$ & $\begin{array}{l}\downarrow 8 \%, 9 \%, 7 \% \text {, and } \\
15 \% \text { in the } 6.25 \%, \\
25 \%, 50 \%, \text { and } 100 \% \\
\text { OTNE groups, } \\
\text { respectively, } \\
\text { compared to their } \\
\text { control groups }\end{array}$ & $\begin{array}{l}\text { Dosed groups similar } \\
\text { to the respective } \\
\text { control groups }\end{array}$ \\
\hline Clinical findings & None & None & None & None \\
\hline $\begin{array}{l}\text { Reproductive } \\
\text { findings }\end{array}$ & None & None & $\begin{array}{l}\downarrow \text { Sperm counts, } \\
\text { motility }\end{array}$ & $\begin{array}{l}\uparrow \text { Cycle length, } \\
\text { extended estrus }\end{array}$ \\
\hline Organ weights & $\begin{array}{l}\uparrow \text { Absolute and } \\
\text { relative liver weights } \\
\uparrow \text { Relative kidney } \\
\text { weight }\end{array}$ & $\begin{array}{l}\uparrow \text { Absolute and } \\
\text { relative liver weights } \\
\uparrow \text { Relative kidney } \\
\text { weight }\end{array}$ & $\begin{array}{l}\uparrow \text { Absolute and } \\
\text { relative liver weights } \\
\downarrow \text { Absolute thymus } \\
\text { weight }\end{array}$ & $\begin{array}{l}\uparrow \text { Absolute and } \\
\text { relative liver weights } \\
\downarrow \text { Absolute and } \\
\text { relative thymus } \\
\text { weights }\end{array}$ \\
\hline $\begin{array}{l}\text { CYP2E1 enzyme } \\
\text { activity }\end{array}$ & None & None & None & None \\
\hline Clinical pathology & $\begin{array}{l}\downarrow \text { Alanine } \\
\text { aminotransferase and } \\
\text { alkaline phosphatase } \\
\text { activities }\end{array}$ & $\begin{array}{l}\downarrow \text { Alanine } \\
\text { aminotransferase and } \\
\text { alkaline phosphatase } \\
\text { activities }\end{array}$ & $\begin{array}{l}\downarrow \text { Erythrocyte count, } \\
\text { hemoglobin } \\
\text { concentration, and } \\
\text { hematocrit }\end{array}$ & $\begin{array}{l}\downarrow \text { Erythrocyte count, } \\
\text { hemoglobin } \\
\text { concentration, and } \\
\text { hematocrit }\end{array}$ \\
\hline
\end{tabular}


OTNE, NTP TOX 92

\begin{tabular}{|c|c|c|c|c|}
\hline & $\begin{array}{c}\text { Male F344/NTac } \\
\text { Rats }\end{array}$ & $\begin{array}{c}\text { Female F344/NTac } \\
\text { Rats }\end{array}$ & $\begin{array}{c}\text { Male B6C3F1/N } \\
\text { Mice }\end{array}$ & $\begin{array}{c}\text { Female B6C3F1/N } \\
\text { Mice }\end{array}$ \\
\hline $\begin{array}{l}\text { Nonneoplastic } \\
\text { effects }\end{array}$ & $\begin{array}{l}\frac{\text { Skin }(\text { site of }}{\text { application): }} \\
\text { hyperkeratosis }(0 / 10, \\
0 / 10,1 / 10,3 / 10 \\
4 / 10,5 / 10,8 / 10) \\
\text { hyperplasia }(0 / 10, \\
0 / 10,2 / 10,4 / 10, \\
5 / 10,8 / 10,10 / 10)\end{array}$ & $\begin{array}{l}\frac{\text { Skin (site of }}{\text { application): }} \\
\text { hyperkeratosis }(0 / 10, \\
0 / 10,0 / 10,4 / 10 \\
5 / 10,7 / 10,7 / 10) \\
\text { hyperplasia }(0 / 10, \\
0 / 10,1 / 10,5 / 10, \\
7 / 10,7 / 10,8 / 10)\end{array}$ & 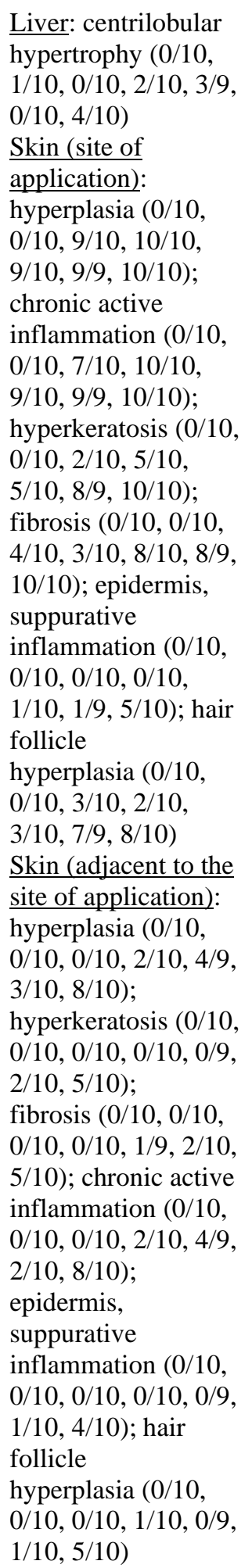 & 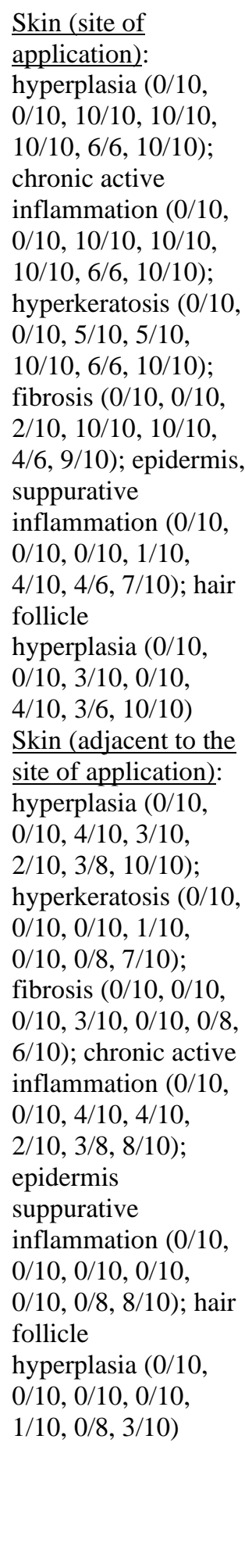 \\
\hline
\end{tabular}


OTNE, NTP TOX 92

\begin{tabular}{|c|c|c|c|}
\hline $\begin{array}{c}\text { Male F344/NTac } \\
\text { Rats }\end{array}$ & $\begin{array}{c}\text { Female F344/NTac } \\
\text { Rats }\end{array}$ & $\begin{array}{c}\text { Male B6C3F1/N } \\
\text { Mice }\end{array}$ & $\begin{array}{c}\text { Female B6C3F1/N } \\
\text { Mice }\end{array}$ \\
\hline \multicolumn{4}{|l|}{ Genetic toxicology } \\
\hline Bacterial gene mutations: & \multicolumn{3}{|c|}{$\begin{array}{l}\text { Not mutagenic in Salmonella typhimurium strains TA98, TA100, or } \\
\text { TA102 or in Escherichia coli strain WP2 uvrA pKM101, with or } \\
\text { without exogenous metabolic activation }\end{array}$} \\
\hline \multicolumn{4}{|l|}{ Micronucleated erythrocytes } \\
\hline Rat peripheral blood in vivo: & \multicolumn{3}{|l|}{ Negative } \\
\hline Mouse peripheral blood in vivo: & \multicolumn{3}{|c|}{ Equivocal in males; positive in females } \\
\hline
\end{tabular}




\section{Introduction}<smiles>CC(=O)C1(C)CC2C(=CCCC2(C)C)CC1C(F)(F)F</smiles><smiles>CC(=O)C1(C)CC2=C(CCCC2(C)C)CC1C</smiles>

$\beta-O T N E$<smiles>CC(=O)C1(C)CC2C(=CC1C)CCCC2(C)C</smiles>

$\gamma$-OTNE

Figure 1. Octahydro-tetramethyl-naphthalenyl-ethanone (OTNE) (CASRN 54464-57-2 ( $\beta$-isomer), 68155-67-9 ( $\alpha$-isomer), 68155-66-8 $\left(\gamma\right.$-isomer); Chemical Formula: $\mathrm{C}_{16} \mathrm{H}_{26} \mathrm{O}$; Molecular Weight: 234.38)

Synonyms: 1' $, 2^{\prime}, 3^{\prime}, 4^{\prime}, 5^{\prime}, 6^{\prime}, 7^{\prime}, 8^{\prime}$-Octahydro-2', $3^{\prime}, 8^{\prime}, 8^{\prime}$-tetramethyl-2'-acetonaphthone; 1,2,3,4,5,6,7,8-octahydro-2,3,8,8tetramethyl-2-acetonaphthone; 1-(1,2,3,4,5,6,7,8-octahydro-2,3,8,8-tetramethyl-2-naphthalenyl)ethanone; 1-(1,2,3,4,6,7,8,8aoctahydro-2,3,8,8-tetramethyl-2-naphthyl)ethan-1-one; 1-(1,2,3,5,6,7,8,8a-octahydro-2,3,8,8-tetramethyl-2-naphthyl)ethan-1-one; 1-(1,2,3,4,5,6,7,8-octahydro-2,3,5,5-tetramethyl-2-naphthyl)ethan-1-one.

Trade Names: Amberonne, Ambralux, Boisvelone, Iso Ambois Super, Iso E Super ${ }^{\circledR}$, Isocyclemone, Isocyclemone E, Orbitone

Octahydro-tetramethyl-naphthalenyl-ethanone (OTNE) is a fragrance ingredient with an unsaturated alkyl cyclic ketone structure that is formed as a mixture of isomers ${ }^{1}$. The main isomer is identified as 1-(1,2,3,4,5,6,7,8-octahydro-2,3,8,8-tetramethyl-2-naphthalenyl)ethanone and is referred to as the $\beta$-isomer ${ }^{2}$. Two other predominant isomers within the mixture are 1 -(1,2,3,4,6,7,8,8a-octahydro-2,3,8,8-tetramethyl-2-naphthalenyl)ethanone ( $\alpha$-isomer) and 1 -(1,2,3,5,6,7,8,8a-octahydro-2,3,8,8-tetramethyl-2-naphthalenyl)ethanone ( $\gamma$-isomer). A typical composition of the mixture consists of $30 \%$ to $65 \%$ by weight of the $\beta$-isomer (CASRN 54464-57-2), $10 \%$ to $26 \% \alpha$-isomer (CASRN 68155-67-9), and $8 \%$ to $20 \% \gamma$-isomer (CASRN 68155-66-8). Minor OTNE isomers also have been identified in mixtures ${ }^{3}$. OTNE is commonly referred to by the commercial name Iso E Super ${ }^{\circledR}$, which is the most prevalent name encountered in the literature.

\section{Chemical and Physical Properties}

The OTNE mixture is in liquid form with a pale-yellow color and an amber or woody odor. Some of the measured or calculated properties of the three primary isomers are listed in Table 1. 
OTNE, NTP TOX 92

Table 1. Physical Properties of Primary OTNE Isomers

\begin{tabular}{llll}
\hline & \multicolumn{1}{c}{$\boldsymbol{\beta}$-Isomer } & \multicolumn{1}{c}{$\boldsymbol{\alpha}$-Isomer } & \multicolumn{1}{c}{$\boldsymbol{\gamma}$-Isomer } \\
\hline Boiling Point $\left({ }^{\circ} \mathrm{C}\right)$ & $110-117 @ 1.0-1.5$ Torr & $311.4 \pm 31.0 @ 760$ Torr $^{\mathrm{a}}$ & $311.4 \pm 31.0 @ 760 \mathrm{Torr}^{\mathrm{a}}$ \\
& $124-135 @ 2.1-2.9$ Torr & & \\
& $312.2 \pm 31.0 @ 760$ Torr \\
& $5.38 \times 10^{-4 \mathrm{a}}$ & & $5.65 \times 10^{-4 \mathrm{a}}$ \\
Vapor Pressure (Torr) & $0.96-0.97 @ 20^{\circ} \mathrm{C}^{\mathrm{b}}$ & Not located & Not located \\
Specific Gravity & $1.077 \mathrm{mg} / \mathrm{L} @ 25^{\circ} \mathrm{C}^{\mathrm{b}}$ & $2.725 \mathrm{mg} / \mathrm{L} @ 25^{\circ} \mathrm{C}^{\mathrm{c}}$ & $2.725 \mathrm{mg} / \mathrm{L} @ 25^{\circ} \mathrm{C}^{\mathrm{c}}$ \\
Water Solubility & $3,720.25 @ \mathrm{pH} 1-10$, & $4,449.43 @ \mathrm{pH} 1-10$, & $4,613.20 @ \mathrm{pH} 1-10$, \\
Bioconcentration Factor & $25^{\circ} \mathrm{C}^{\mathrm{a}}$ & $25^{\circ} \mathrm{C}^{\mathrm{a}}$ & $25^{\circ} \mathrm{C}^{\mathrm{a}}$ \\
\hline
\end{tabular}

${ }^{\mathrm{a} C a l c u l a t e d ~ p r o p e r t i e s ~ u s i n g ~ A d v a n c e d ~ C h e m i s t r y ~ D e v e l o p m e n t ~(A C D / L a b s) ~ S o f t w a r e ~ V 11.02 ~(C 1994-2013 ~ A C D / L a b s) . ~}$



${ }^{\mathrm{c} B e l s i t o}$ et al. ${ }^{1}$

\section{Production, Use, and Human Exposure}

OTNE is produced commercially by Diels-Alder condensation of $\beta$-myrcene with 3-methyl-3pentene-2-one in the presence of aluminum chloride to give a monocyclic intermediate that is cyclized in the presence of $85 \%$ phosphoric acid ${ }^{5}$. OTNE is manufactured in a semicontinuous process with minimal potential for occupational exposure. The annual volumes of OTNE produced in North America for 2000, 2004, 2008, and 2011 were 700, 1,300, 2,100, and 2,800 tons/year, respectively ${ }^{3}$. The total reported production volume for each of the predominant OTNE isomers $(\alpha, \beta$, and $\gamma)$ as reported in the nonconfidential 2006 Inventory Update Rule (IUR), range from $1,000,000$ to less than $10,000,000$ pounds per year. In 2012, the production volume of the $\beta$-isomer was $1,000,000$ to $10,000,000$ pounds per year in the Chemical Data Reporting database ${ }^{6-8}$.

A search found more than 30 products containing OTNE for use as a perfume ingredient in soap, shampoo, cologne, liquid detergent compounds, and malodor-reducing compounds, such as fabric freshening compounds, antiperspirants or deodorants, and air freshening compounds. Typical OTNE concentrations are less than $1 \%$ in household products, and fine fragrance ingredients may contain up to $20 \% \mathrm{OTNE}^{3 ; 4}$.

For the general population, exposure to OTNE is via inhalation and the skin through the use of products (e.g., fragrances and perfumed personal care products) containing the ingredient. Additional exposures may result from ingestion of water or food containing the ingredient as a contaminant. In one human study, OTNE was detected in $34 \%$ of breast milk samples $(37 / 110$ samples) above the method detection limit, but the levels were below the method quantification limit of $1.5 \mathrm{ng} / \mathrm{g}$ lipid ${ }^{9}$. Human dermal systemic exposure to OTNE ( $\beta$-isomer) was calculated to be $0.4604 \mathrm{mg} / \mathrm{kg}$ per day based upon the concentrations in 10 personal care and cosmetic products, the amount of the product applied, the number of applications per day of each product, and the length of time the product was present on the skin ${ }^{4}$.

Detection of OTNE in the environment (e.g., sludge, wastewater, river water, and house dust samples) provides documentation for its use as well as exposure scenarios to humans and aquatic life. OTNE was detected in the majority of house dust samples obtained from Canadian homes. OTNE was detected in $82 \%$ of the samples collected from the vacuum systems used by the 
participants, and concentrations ranged from not detected to $5,620 \mathrm{ng} / \mathrm{g}$ with a median concentration of $212 \mathrm{ng} / \mathrm{g}$. In fresh house dust samples, the detection frequency was $94 \%$. The concentration range and median concentrations extended from not detected to $125,000 \mathrm{ng} / \mathrm{g}$ and $252 \mathrm{ng} / \mathrm{g}$, respectively ${ }^{10}$ (Note: the study references the trade name Iso E Super ${ }^{\circledR}$ and the $\beta$-isomer CASRN). OTNE was also detected in municipal wastewater and in effluents from water treatment facilities within the United States and Germany ${ }^{11 ; 12}$. In United States facilities with activated sludge or trickling filter wastewater treatment, OTNE influent concentrations were 3.470 and $3.250 \mu \mathrm{g} / \mathrm{L}$, respectively, and final effluent concentrations were 0.110 and $0.334 \mu \mathrm{g} / \mathrm{L}$, respectively. Thus, a $96.8 \%$ removal rate was achieved via activated sludge wastewater treatment versus $89.7 \%$ removal following trickling filter wastewater treatment ${ }^{13}$ (Note: studies reference, either through CASRN or structure, the $\beta$-isomer). Furthermore, studies have indicated that OTNE is degraded in environmental samples. In a river water test, degradation half-lives of 5 days or less were reported. In soil core and leachate samples, OTNE levels decreased by $60 \%$ after 3 months and were not detected within 1 year. The maximum measured bioaccumulation factor was noted to be 850 in bluegill fish. Evaluated metabolites of OTNE were more polar than the parent, suggesting that they were not likely to accumulate ${ }^{3}$.

\section{Regulatory Status}

In the United States, OTNE is listed in the Toxic Substances Control Act (TSCA) Inventory under the 9CI name ethanone, 1-(1,2,3,4,5,6,7,8-octahydro-2,3,8,8-tetramethyl-2-naphthalenyl); this is specific to the $\beta$-isomer. In 2012, the USEPA added four of the OTNE isomers (CASRNs: 54464-57-2; 54464-59-2; 68155-66-8; 68155-67-9) to the TSCA Work Plan for Chemical Assessments ${ }^{14}$. As of 2014, the isomers are still listed in the TSCA Work Plan Update for their evaluation regarding environmental persistence and occurrence ${ }^{15}$.

\section{Absorption, Distribution, Metabolism, Excretion, and Toxicokinetics}

\section{Experimental Animals}

There are limited data on the absorption, distribution, metabolism, excretion, and toxicokinetics of OTNE in experimental animals, although OTNE disposition can be inferred from data summaries submitted to the Registration, Evaluation, Authorisation, and Restriction of Chemicals (REACH) Dossiers available in the European Chemicals Agency (ECHA) database as well as in a published summary of industry studies ${ }^{4}$. In one such report, maternal transfer was assessed in pregnant Sprague Dawley rats by gavage administration of 2 or $20 \mathrm{mg}\left[{ }^{14} \mathrm{C}\right] \mathrm{OTNE} / \mathrm{kg}$ body weight in corn oil from gestation day 14 to postnatal day $7^{16}$. Milk and blood samples were collected from dams on postnatal days 3 and 7 at 4, 8, and 24 hours following dose administration. Total radioactivity levels in plasma and milk decreased with time, and unmetabolized OTNE was not detected in the milk. Low levels of radioactivity were detected by whole-body radiography in the placenta and fetus following exposure of pregnant Sprague Dawley rats from gestation days 14 to 19 to $2 \mathrm{mg}\left[{ }^{14} \mathrm{C}\right] \mathrm{OTNE} / \mathrm{kg}$ body weight, suggesting minimal maternal transfer of OTNE. Radioactivity also was present in the small intestine contents, preputial gland, stomach, liver, large intestine contents, thyroid gland, and bladder of the dams. 
The disposition of OTNE in male F344 rats after gavage or dermal exposure was studied by NTP using $\left[{ }^{14} \mathrm{C}\right] \mathrm{OTNE}$ ( $\beta$-isomer) ${ }^{17}$. $\beta$-OTNE was well absorbed following gavage administration of $20 \mathrm{mg} / \mathrm{kg}$, and the majority of the administered dose was excreted in urine $(28 \%)$ and feces (39\%) by 48 hours. Approximately $73 \%$ of the $20 \mathrm{mg} / \mathrm{kg}$ dose was eliminated in bile in 48 hours confirming that the fecal excretion was not due to poor absorption but biliary excretion. Additionally, approximately $80 \%$ of the dose in the bile was excreted within the first 4 hours, while the fecal excretion continued through 48 hours suggesting enterohepatic recirculation of OTNE. Radioactivity in tissues reached maximal levels between 4 and 8 hours, and the highest levels of radioactivity were found in the liver, kidney, pancreas, and adipose. The estimated elimination half-lives, based on the total radioactivity, were greater than or equal to 20 hours in blood and most tissues examined. Profiling of urine showed the presence of at least nine metabolites, although the identities of the metabolites were not determined.

Disposition was also examined by NTP in male F344 rats following a single dermal application of 55 or $550 \mathrm{mg} / \mathrm{kg}\left[{ }^{14} \mathrm{C}\right] \beta$-OTNE in ethanol to covered and uncovered dose sites after 24 , 48 , or 96 hours ${ }^{17}$. For comparison with the 3 -month dermal studies in rats, the corresponding formulation concentrations were $0.55 \%$ and $5.5 \%$ OTNE. There was a general trend that the percent dose absorbed increased and the percent dose at dose-site skin decreased with time in both covered and uncovered groups. When the dose site was covered, approximately $14 \%$ of the applied dose was absorbed by 96 hours in both 55 and $550 \mathrm{mg} / \mathrm{kg}$ groups. When the dose site was uncovered, the total dose absorbed 96 hours postdosing was 33\% and 72\%, for 55 and $550 \mathrm{mg} / \mathrm{kg}$, respectively, suggesting significant absorption due to oral grooming. Similar to gavage administration, the primary routes of excretion were through feces (4.0\% to $12.3 \%)$ and urine $(5.1 \%$ to $13.7 \%)$ at 96 hours in covered and uncovered animals, respectively. The highest levels of radioactivity were found in the liver, kidney, adipose, and pancreas. Blood elimination half-lives estimated for 55 and $550 \mathrm{mg} / \mathrm{kg}$ uncovered dose groups were 70 and 40 hours, respectively; half-lives for covered dose groups were not reported due to the lack of sufficient data points to define the blood concentration versus time profiles.

\section{Humans}

Human summary data regarding the absorption of OTNE have been submitted to REACH and are available in the ECHA database. In this in vitro absorption study, $1 \%\left[{ }^{14} \mathrm{C}\right] \mathrm{OTNE}(\mathrm{w} / \mathrm{v})$ in ethanol was applied to human epidermis ${ }^{18}$. Permeation was measured from 2 through 48 hours, and results indicated that approximately $29 \%$ of the applied dose was absorbed. The rate of permeation was linear with no plateau noted.

\section{Toxicity}

\section{Experimental Animals}

The reported oral and dermal acute toxicity values (LD $\mathrm{L}_{50}$ ) were greater than $5,000 \mathrm{mg} / \mathrm{kg}$ in male and female TacN(SD)fBR and Sprague Dawley rats ${ }^{4 ; 19 ; 20}$.

In a 28-day subchronic study in male and female Sprague Dawley rats, OTNE was administered orally at 50,150, or 1,000 mg/kg in corn oil. A subset of animals was kept in housing an additional 14 days to assess recovery. The study summary, available in the ECHA database and summarized by Scognamiglio et al. ${ }^{4}$, indicated that no treatment-related deaths occurred, but 
poor grooming, decreased body weights, and increased water consumption were observed during treatment in the high dose males and females. All effects were reversed during the 14-day recovery period. Treatment-related effects were reported in high dose animals (e.g., increased cholesterol levels in males and females as well as decreased glutamic pyruvic transaminase levels in males). Increased liver weights and centrilobular hepatocyte enlargement were observed in high dose males and females. Eosinophilic inclusions in the cortical tubules were noted in mid- and high-dose males; some recovery was observed in high dose males. The report summary concluded that the no-observed-adverse-effect level (NOAEL) and no-observed-effect level (NOEL) for OTNE when administered orally for at least 4 weeks are 1,000 and $15 \mathrm{mg} / \mathrm{kg}$ body weight per day, respectively ${ }^{4 ; 21}$.

Contact sensitization and irritancy following dermal exposure to OTNE in an acetone:olive oil (4:1) vehicle was evaluated in female $\mathrm{BALB} / \mathrm{c}$ mice by $\mathrm{NTP}^{22}$. To reduce the number of animals needed for the studies, the local lymph node assay (LLNA) and irritancy assay were combined. All mice treated with OTNE $(0.5 \%, 1 \%, 2.5 \%, 5 \%, 25 \%$, or $50 \%$ applied to the dorsum of the ear) demonstrated significant irritation at the site of application, as measured by swelling of the ear pinna 24 hours after the last exposure. In the LLNA, significant increases in lymph node cell proliferation were observed in the $25 \%$ and $50 \%$ groups only (172\% and $467 \%$, respectively, as compared to vehicle controls). The maximum stimulation index (SI) for these studies was 5.68 in the 50\% OTNE group. The SI is the ratio of lymph node cell proliferation in the OTNE test group to that of the matched vehicle control group. A substance is considered a dermal sensitizer if at least one concentration of the test article results in a mean SI of 3 or more, although statistically significant changes in disintegrations per minute below the SI $=3$ threshold are also considered. To further investigate the sensitization potential of OTNE, the Mouse Ear Swelling Test was performed. In the sensitization phase, three concentrations of OTNE $(0.5 \%, 5 \%$, and $50 \%$ ) were used, and 50\% OTNE was applied during the challenge phase. OTNE did not significantly increase mouse ear thickness at either 24 or 48 hours postchallenge at any of the concentrations evaluated. These results suggest that, under the experimental conditions utilized in this study in female BALB/c mice, the positive response in the LLNA was likely due to the irritant effects of OTNE.

OTNE-induced skin hypersensitivity was examined in multiple LLNA studies with female $\mathrm{CBA} / \mathrm{J}$ mice. The results are reported by the European Chemicals Agency and classify OTNE as a skin sensitizer following application of $2.5 \%, 5 \%, 10 \%, 25 \%$, or $50 \%$ OTNE (v/v) in 3:1 diethyl phthalate:ethanol ${ }^{23-25}$. The SI values for these studies ranged from 11.3 to 34.2 when $50 \%$ OTNE was applied. The full study reports for these investigations were not available (Robust Summary Data from REACH Dossiers in the ECHA database) so it is not clear whether the doses used in these LLNA studies were nonirritating or whether the differences in the results were due to the animal strains or vehicles used.

\section{Humans}

The majority of OTNE-related toxicity studies in humans have been to examine whether its dermal application can cause skin irritation or sensitization. When OTNE was applied in a patch test, two cases (out of 1,069 patients) of an allergic reaction were observed on day 3 or 4 of application $^{26}$. More recently, $0.2 \%$ of tested individuals (1,855 patients) were identified as sensitive to $\mathrm{OTNE}^{27}$ (Note: the study references the trade name Iso E Super ${ }^{\circledR}$ and 
CASRN 54464-57-2). In another evaluation, OTNE sensitization was reported in $1.7 \%$ of fragrance-sensitive individuals (178 volunteer patients) subjected to a patch test ${ }^{28}$.

The European Chemicals Agency has reported the results of several human patch test studies, which are also summarized by Scognamiglio et al. ${ }^{4}$ and Belsito et al. ${ }^{1}$. In one study, OTNE irritation potential was examined with $20 \%, 40 \%, 60 \%$, or $75 \%$ test article applied two times over a 96-hour period in 23 subjects $^{29}$. At $20 \%$ OTNE, minimal erythema was reported in select individuals, however, dermal irritation was negligible in $40 \%$ to $75 \%$ OTNE-treated subjects. In a different repeated patch test study conducted on 101 individuals, the potential for OTNE to induce contact sensitization was examined ${ }^{30}$. OTNE was applied via an occluded patch, and applications were repeated three times per week for 3 weeks. Ten to 17 days after the last application, a challenge patch was applied and the response was evaluated 24, 48, and 72 hours later. Slight to mild transient erythema was observed in 17 individuals during the 3-week induction phase. During the challenge phase, four individuals experienced slight or mild erythema at the later time points.

In vitro studies using reconstructed human epidermis classified OTNE as an irritant to the skin ${ }^{31}$.

\section{Reproductive and Developmental Toxicity}

\section{Experimental Animals}

There are no data on the reproductive toxicity of OTNE in the literature and limited data on developmental toxicity of OTNE in experimental animals ${ }^{2 ; 32}$. In a preliminary study, pregnant Sprague Dawley rats were orally gavaged with $240,480,960$, or $1,920 \mathrm{mg} / \mathrm{kg}$ OTNE (neat material) or water (control) from gestation days 7 to 17 . Rats were euthanized on gestation day 21, and one rat was euthanized moribund on gestation day 16. Clinical signs in all treated animals included chromorhinorrhea, excessive salivation, and the presence of a red perioral substance. Urine stained abdominal fur was noted in the two highest dose groups, and amber colored urine was observed in the highest dose group. No statistically significant effects were noted in litter parameters.

Following the preliminary study, pregnant Sprague Dawley rats were orally gavaged with 96, 240 , or $480 \mathrm{mg} / \mathrm{kg}$ body weight per day from gestation days 7 to $17^{2}$. Rats were euthanized on gestation day 21. No treatment-related deaths were reported. Clinical signs attributed to treatment included increased salivation at all doses and an increased incidence of urine-stained abdominal fur in high dose animals. Body weight gain was lower at all dose levels from gestation days 7 to 10 . Additionally, high dose dams exhibited lower body weight gain from gestation days 11 to 21 . Feed consumption was lower in all dosed groups. No treatment-related effects were observed on uterine parameters (e.g., implantations); gross external, soft tissue, or skeletal malformations; or number of ossification sites/fetus per litter. The maternal and developmental NOAEL was reported as $240 \mathrm{mg} / \mathrm{kg}$ per day.

\section{Humans}

No studies were found in the literature on the reproductive or developmental toxicity of OTNE in humans. 


\section{Carcinogenicity}

No carcinogenicity studies of OTNE in experimental animals or epidemiology studies in humans have been reported in the literature.

\section{Genetic Toxicity}

No studies were found in the open literature on the genotoxicity of OTNE. However, little genotoxic potential for OTNE can be inferred from data submitted to REACH and available in the ECHA database. In these industry-sponsored studies, OTNE (dissolved in DMSO) was reported to be negative in bacterial mutagenicity tests that employed Salmonella typhimurium strains TA98, TA100, TA1535, TA1537, or TA1538 or Escherichia coli strain WP2 uvrA. OTNE concentrations ranged from 312.5 to $5,000 \mu \mathrm{g} / \mathrm{plate}$, with or without induced rat liver S9 activation enzymes ${ }^{33}$, and no cytotoxicity was reported at any of the tested concentrations. In mammalian cells, no mutagenicity was observed in mouse lymphoma L5178Y $\mathrm{tk}^{+/-}$cells treated with OTNE (dissolved in ethanol) at concentrations up to $90 \mu \mathrm{g} / \mathrm{mL}$ in the presence of $\mathrm{S} 9$ and at concentrations up to $40 \mu \mathrm{g} / \mathrm{mL}$ without $\mathrm{S}^{34}$. The effect of OTNE (dissolved in DMSO) on chromosomal aberrations was assessed in human lymphocytes with standard and extended incubation times ${ }^{35}$. OTNE was considered to be negative for inducing chromosomal aberrations when tested at concentrations up to $125 \mu \mathrm{g} / \mathrm{mL}$ in the presence of $\mathrm{S} 9$ and at concentrations up to $50 \mu \mathrm{g} / \mathrm{mL}$ without $\mathrm{S}^{34}$. Although these test results are freely available in the ECHA database and are summarized in Scognamiglio et al. ${ }^{4}$, lack of access to the original studies precludes independent assessment of the data or the protocols under which they were generated.

\section{Study Rationale}

The fragrance ingredient OTNE was nominated by a private individual for toxicology testing based on its widespread use as a constituent of a fragrance mixture and the lack of toxicity data via a relevant route of exposure. In response, NTP conducted 3-month toxicity studies of OTNE administered by dermal application to male and female F344/NTac rats and B6C3F1/N mice. 


\section{Materials and Methods}

\section{Procurement and Characterization}

\section{OTNE}

OTNE (octahydro-tetramethyl-naphthalenyl-ethanone) was obtained as Iso-E Super ${ }^{\circledR}$ from International Flavors and Fragrances, Inc. (Ringwood, NJ), in one lot (RAV0276433) that was used in the 3-month dermal studies. Identity and purity analyses were conducted by the analytical chemistry laboratory at Research Triangle Institute (Research Triangle Park, NC), and purity analyses were conducted by the study laboratory at BioReliance Corporation (Rockville, MD) (Appendix F). Reports on analyses performed in support of the OTNE studies are on file at the National Institute of Environmental Health Sciences.

The chemical, a colorless to pale-yellow liquid, was identified as OTNE using infrared and proton nuclear magnetic resonance spectrometry and gas chromatography (GC) with mass spectrometry (MS) detection. All spectra were consistent with the structure of OTNE isomers. The purity of the test chemical was determined using GC with flame ionization detection (FID) and GC/MS. GC/FID analysis indicated four major peaks and nine minor peaks; each of the minor peaks was less than $1 \%$ of the total peak area. GC/MS analysis indicated mass spectra for the major peaks that were very similar, showing the same fragments with slight variations in relative abundance: These were tentatively identified as $\beta$-isomer, $\alpha$-isomer, $\gamma$-isomer, and 1 (1,2,3,4,5,6,7,8-octahydro-2,3,5,5-tetramethyl-2-naphthalenyl)-ethanone based on the spectra and comparison to the literature ${ }^{36}$. The overall purity of lot RAV0276433 was estimated to be greater than $96 \%$ relative to the four OTNE isomers: $\beta$-isomer $(56.6 \%), \alpha$-isomer $(18.0 \%), \gamma$ isomer (17.7\%), and 1-(1,2,3,4,5,6,7,8-octahydro-2,3,5,5-tetramethyl-2-naphthalenyl)-ethanone (3.9\%). To ensure stability, the test chemical was stored in sealed amber glass vials at room temperature under a desiccant. Reanalysis of the test chemical was performed at the end of the study by the study laboratory using GC/FID; no degradation of the test chemical was detected.

\section{Ethanol}

USP-grade 95\% ethanol was obtained from Pharmco Products, Inc. (Brookfield, CT), in one lot (M0000) that was used as the vehicle in the 3-month dermal studies.

\section{Preparation and Analysis of Dose Formulations}

Except for the $100 \%$ dose formulations, which were used neat, the dose formulations were prepared by mixing OTNE with $95 \%$ ethanol to give the required concentrations and stirring with a magnetic stir bar for at least 15 minutes. The dose formulations were stored in a flammable chemical storage cabinet in amber glass bottles sealed with Teflon ${ }^{\circledR}$ silicone septa and an aluminum crimp seal under a nitrogen headspace at room temperature $\left(\sim 25^{\circ} \mathrm{C}\right)$. The dose formulations were prepared three times during the 3-month studies and analyzed for percent of target concentration (Table F-2). All 30 dose formulations analyzed for rats and mice were within $10 \%$ of the target concentrations. Animal room samples of these dose formulations were also analyzed; 28 of 30 for rats and 26 of 30 for mice were within $10 \%$ of the target concentrations. 


\section{Animal Source}

Male and female F344/NTac rats were obtained from the commercial colony at Taconic Farms, Inc. (Germantown, NY), and B6C3F1/N mice were obtained from the NTP colony at Taconic Farms, Inc. The rationale for change of rat strain from F344/N to F344/NTac was a programmatic decision. For many years, NTP used the inbred F344/N rat for its toxicity and carcinogenicity studies. Over a period of time, the F344/N rat exhibited sporadic seizures, idiopathic chylothorax, and consistently high rates of mononuclear cell leukemia and testicular neoplasia. Because of these issues in the F344/N rat and NTP's desire to find a more fecund rat model that could be used in both reproductive and carcinogenesis studies for comparative purposes, a change in the rat model was explored. Following a workshop in 2005, the F344 rat from the Taconic commercial colony (F344/NTac) was used for a few NTP studies to allow NTP to evaluate different rat models ${ }^{37}$. The F344/NTac rat was used in four subchronic and two chronic studies between 2005 and 2006.

\section{Animal Welfare}

Animal care and use are in accordance with the Public Health Service policy on Humane Care and Use of Animals. All animal studies were conducted in an animal facility accredited by the Association for the Assessment and Accreditation of Laboratory Animal Care International. Studies were approved by the BioReliance Corporation Animal Care and Use Committee and conducted in accordance with all relevant NIH and NTP animal care and use policies and applicable federal, state, and local regulations and guidelines.

\section{Three-month Studies}

On receipt, rats were 3 to 4 weeks old and mice were 4 to 5 weeks old. Animals were quarantined for 12 or 13 days (rats) or 14 or 15 days (mice); rats were 5 to 6 weeks old and mice were 6 to 7 weeks old on the first day of the studies. Before the studies began, five male and five female rats and mice were randomly selected for parasite evaluation and gross observation for evidence of disease. The health of the animals was monitored during the studies according to the protocols of the NTP Sentinel Animal Program (Appendix H). All test results were negative.

Groups of 10 male and 10 female rats and mice received no treatment (untreated control) or dermal application of OTNE in $95 \%$ aqueous ethanol at concentrations of $0 \%$ (vehicle control), $6.25 \%, 12.5 \%, 25 \%, 50 \%$, or $100 \%$ (neat) 5 days per week for 3 months (13 weeks). Groups of 10 male and 10 female special study rats received the same doses for 22 days. The study design included a second control group (untreated control) to allow for the appropriate comparison of the high dose group (100\% OTNE) to a control group without aqueous ethanol. Formulations were administered at a volume of $0.5 \mathrm{~mL} / \mathrm{kg}$ body weight (rats) or $2.0 \mathrm{~mL} / \mathrm{kg}$ (mice). Thus, applied concentrations corresponded to 31.25 to $500 \mathrm{mg}$ OTNE/ $\mathrm{kg}$ body weight in rats and 125 to $2,000 \mathrm{mg} / \mathrm{kg}$ in mice. Doses were applied using a repeating pipette with a disposable tip to a consistent area that was shaved weekly. The shaved area was on the dorsal surface just posterior to the scapulae to the base of the tail and larger than the application site. The untreated control rats and mice were shaved similarly but received no liquid application, much like a sham control. Feed and water were available ad libitum. Rats and mice were housed individually. All animals were weighed, and clinical findings were recorded initially, weekly, and at the end of the studies. 
Details of the study design and animal maintenance are summarized in Table 2. Information on feed composition and contaminants is provided in Appendix G.

On days 3 and 23, blood was collected from the retroorbital plexus of special study rats for hematology and clinical chemistry analyses only (no additional evaluations in mice). Blood was collected from the retroorbital plexus and sinus of core study rats and mice, respectively, at the end of the 3-month studies for hematology and clinical chemistry (rats) analyses. Blood for hematology analyses was placed in tubes containing EDTA as the anticoagulant. Hematology parameters were determined using an ABX Pentra $60 \mathrm{C}$ + analyzer (HORIBA Instruments, Inc., Irvine, CA). For clinical chemistry analyses, blood samples were placed in serum separator tubes and centrifuged, and the serum was analyzed using a Hitachi 717 chemistry analyzer (Boehringer Mannheim, Indianapolis, IN) and commercially available reagents. The parameters measured are listed in Table 2.

The vehicle, ethanol, is metabolized by cytochrome P4502E1 (Cyp2e1) to form reactive products that are associated with hepatic injury ${ }^{38}$. In order to distinguish potential OTNE-related effects on the liver from ethanol-induced liver changes, Cyp2el activity was also measured in control and dosed groups. At the scheduled euthanasia of special study rats on day 23 , consistent portions of the median and left lateral liver lobes not scheduled for histologic evaluation were excised from the first five male and female rats per dose group encountered during the random order for bleeds. Comparable sections of the livers were excised from the first five male and female core study rats scheduled for necropsy at the end of the study. For mice, the entire portion of the liver not used for histologic evaluation was excised from the first five male and female mice per dose group necropsied at the end of the study. The liver portions were immediately flash frozen at $-60^{\circ} \mathrm{C}$ or less. The rat and mouse liver samples were shipped on dry ice to In Vitro Technologies (IVT, Baltimore, MD). Upon arrival, liver samples were stored at $-70^{\circ} \pm 10^{\circ} \mathrm{C}$ until processed into microsomes. IVT prepared microsomes from the livers by differential centrifugation and analyzed the liver samples for total protein by the bicinchoninic acid (BCA) method using the BCA Protein Assay Kit (Pierce Chemical Co., Rockford, Il). Cyp2el activity was measured by monitoring lauric acid 11-hydroxylase activity. Microsomes were incubated with $\left[{ }^{14} \mathrm{C}\right]$ lauric acid and a NADPH-regenerating system, and the rate of formation of 11-hydroxylauric acid was analyzed using a radiometric high performance liquid chromatography (HPLC) method. Two replicates of each liver sample were analyzed for all dosed and control groups.

At the end of the 3-month studies, samples were collected for sperm motility and vaginal cytology evaluations on core study rats and mice in the untreated control, vehicle control, 25\%, $50 \%$, and $100 \%$ OTNE groups. The parameters evaluated are listed in Table 2. For 16 consecutive days prior to scheduled terminal euthanasia, the vaginal vaults of the females were moistened with saline, if necessary, and samples of vaginal fluid and cells were stained. Relative numbers of leukocytes, nucleated epithelial cells, and large squamous epithelial cells were determined and used to ascertain estrous cycle stage (i.e., diestrus, proestrus, estrus, and metestrus). Male animals were evaluated for sperm count and motility. The left testis and left epididymis were isolated and weighed. The tail of the epididymis (cauda epididymis) was then removed from the epididymal body (corpus epididymis) and weighed. Test yolk (rats) or modified Tyrode's buffer (mice) was applied to slides and a small incision was made at the distal border of the cauda epididymis. The sperm effluxing from the incision were dispersed in the buffer on the slides, and the numbers of motile and nonmotile spermatozoa were counted for 
five fields per slide by two observers. Following completion of sperm motility estimates, each left cauda epididymis was placed in buffered saline solution. Caudae were finely minced, and the tissue was incubated in the saline solution and then heat fixed at $65^{\circ} \mathrm{C}$. Sperm density was then determined microscopically with the aid of a hemacytometer. To quantify spermatogenesis, the testicular spermatid head count was determined by removing the tunica albuginea and homogenizing the left testis in phosphate-buffered saline containing $10 \%$ dimethyl sulfoxide. Homogenization-resistant spermatid nuclei were counted with a hemacytometer.

Necropsies were performed on all core study rats and mice. The heart, right kidney, liver, lung, right testis, and thymus were weighed. Tissues for microscopic examination were fixed and preserved in 10\% neutral buffered formalin (eyes were first fixed in Davidson's solution), processed and trimmed, embedded in paraffin, sectioned to a thickness of 4 to $6 \mu \mathrm{m}$, and stained with hematoxylin and eosin. Complete histopathologic examinations were performed by the study laboratory pathologist on rats and mice in the untreated control, vehicle control, and $100 \%$ OTNE groups. The skin at the site of application, skin adjacent to the site of application, and control skin were examined in all groups of rats and mice, and the liver was examined in all groups of rats and mice. Table 2 lists the tissues and organs routinely examined.

After a review of the laboratory reports and selected histopathology slides by a quality assessment (QA) pathologist, the findings and reviewed slides were submitted to a NTP Pathology Working Group (PWG) coordinator for a second independent review. Any inconsistencies in the diagnoses made by the study laboratory and QA pathologists were resolved by the NTP pathology peer review process. Final diagnoses for reviewed lesions represent a consensus of the PWG or a consensus between the study laboratory pathologist, NTP pathologist, QA pathologist(s), and the PWG coordinator. Details of these review procedures have been described, in part, by Maronpot and Boorman ${ }^{39}$ and Boorman et al. ${ }^{40}$.

Table 2. Experimental Design and Materials and Methods in the Three-month Dermal Studies of OTNE

Three-month Study

\section{Study Laboratory}

BioReliance Corporation (Rockville, MD)

\section{Strain and Species}

F344/NTac rats

B6C3F1/N mice

\section{Animal Source}

Taconic Farms, Inc. (Germantown, NY)

\section{Time Held Before Studies}

Rats: 12 (males) or 13 (females) days Mice: 14 (males) or 15 (females) days

\section{Average Age When Studies Began}

Rats: 5 to 6 weeks

Mice: 6 to 7 weeks 
OTNE, NTP TOX 92

\section{Three-month Study}

\section{Date of First Dose}

Rats: December 12 (males) or December 13 (females), 2006

Mice: December 14 (males) or December 15 (females), 2006

Duration of Dosing

3 months (13 weeks)

Date of Last Dose

Rats: March 12 (males) or March 13 (females), 2007

Mice: March 14 (males) or March 15 (females), 2007

Necropsy Dates

Rats: March 13 (males) or March 14 (females), 2007

Mice: March 15 (males) or March 16 (females), 2007

\section{Average Age at Necropsy}

Rats: 18 or 19 weeks

Mice: 19 or 20 weeks

\section{Size of Study Groups}

10 males and 10 females

\section{Method of Distribution}

Animals were distributed randomly into groups of approximately equal initial mean body weights.

\section{Animals per Cage}

\section{Method of Animal Identification}

Tail tattoo

\section{Diet}

Irradiated NTP-2000 pelleted diet (Zeigler Brothers, Inc., Gardners, PA), available ad libitum, changed weekly

\section{Water}

Tap water (Washington Suburban Sanitary Commission, Potomac Plant) via automatic watering system (Edstrom Industries, Inc., Waterford, WI), available ad libitum

\section{Cages}

Polycarbonate (Lab Products, Inc., Seaford, DE), changed weekly

\section{Bedding}

Irradiated heat-treated, Sani-Chip hardwood bedding (P.J. Murphy Forest Products, Montville, NJ); changed weekly

\section{Cage Filters}

Omnishield paper, Remay 2024 (DuPont); changed every 2 weeks

\section{Racks}

Stainless steel (LabProducts, Inc., Seaford, DE); changed every 2 weeks 


\section{Three-month Study}

\section{Animal Room Environment}

Temperature: $72^{\circ} \pm 3^{\circ} \mathrm{F}$

Relative humidity: $50 \% \pm 15 \%$

Room fluorescent light: 12 hours/day

Room air changes: $\geq 10 /$ hour

\section{Doses}

Untreated control, $0 \%$ (vehicle control), $6.25 \%, 12.5 \%, 25 \%, 50 \%$, or $100 \%$ (neat) OTNE

\section{Type and Frequency of Observation}

Observed twice daily; core study animals were weighed and clinical findings were recorded initially, on day 8 , weekly thereafter, and at the end of the studies.

\section{Method of Euthanasia}

Carbon dioxide asphyxiation

\section{Necropsy}

Necropsies were performed on all core study rats and mice. Organs weighed were heart, right kidney, liver, lung, right testis, and thymus.

\section{Clinical Pathology}

Blood was collected from the retroorbital plexus of special study rats on days 3 and 23 and from core study rats at the end of the study for hematology and clinical chemistry. Blood was collected from the retroorbital sinus of core study mice at the end of the study for hematology.

Hematology: hematocrit (automated and manual); hemoglobin; erythrocyte, reticulocyte, and platelet counts; erythrocyte distribution of width; mean platelet volume; mean cell volume; mean cell hemoglobin; mean cell hemoglobin concentration; and leukocyte count and differentials Clinical Chemistry: urea nitrogen, creatinine, total protein, albumin, alanine aminotransferase, alkaline phosphatase, creatine kinase, sorbitol dehydrogenase, and bile acids

\section{Histopathology}

Complete histopathology was performed on core study rats and mice in the untreated control, vehicle control, and $100 \%$ OTNE groups. In addition to gross lesions and tissue masses, the following tissues were examined: adrenal gland, bone (femur) with marrow, brain, clitoral gland, esophagus, eye, gallbladder (mice), Harderian gland, heart and aorta, large intestine (cecum, colon, rectum), small intestine (duodenum, jejunum, ileum), kidney, liver, lung (with mainstem bronchus), lymph nodes (mandibular and mesenteric), mammary gland, nose, oral cavity and larynx, ovary, pancreas, parathyroid gland, pituitary gland, preputial gland, prostate gland, salivary gland, seminal vesicle, skin (site of application and control sites), spleen, stomach (forestomach and glandular), testis with epididymis, thymus, thyroid gland, tongue, trachea, urinary bladder, and uterus.

\section{Sperm Motility and Vaginal Cytology}

At the end of the studies, sperm samples were collected from male rats and mice in the untreated control, vehicle control, $25 \%, 50 \%$, and $100 \%$ OTNE groups for sperm motility evaluations. The following parameters were evaluated: spermatid heads per gram testis and per testis, and epididymal spermatozoal motility and concentration. The left cauda, left epididymis, and left testis were weighed. Vaginal samples were collected for up to 16 consecutive days prior to the end of the studies from female rats and mice in the untreated control, vehicle control, $25 \%, 50 \%$, and $100 \%$ OTNE groups for vaginal cytology evaluations.

\section{Liver Cytochrome P450 Activity}

Liver samples were collected from five male and five female special study rats per dose group on day 23 and from five male and five female core study rats and mice per dose group at the end of the studies. Livers were analyzed for total microsomal protein content and Cyp2el activity. 


\section{Statistical Methods}

For all statistical comparisons, the data from the $100 \%$ OTNE groups were compared to the untreated control groups. Data from OTNE-treated groups (6.25\% to 50\%) were compared to the vehicle controls. With the exception of micronucleus data presented in Appendix E, statistical comparisons between the vehicle control and untreated control groups are not presented in this Toxicity Study Report. In general, there were no statistically significant differences between control groups except in two instances. First, Cyp2e1 activity was decreased $36 \%$ in female rats from the vehicle control group compared to the untreated control group. Second, the mean final body weights of male mice were $7 \%$ lower in the vehicle controls compared to the untreated controls. The biological significance of these two discrepancies was considered negligible.

\section{Calculation and Analysis of Lesion Incidences}

The incidences of lesions are presented in Appendix A as numbers of animals bearing such lesions at a specific anatomic site and the numbers of animals with that site examined microscopically. The Fisher exact test ${ }^{41}$, a procedure based on the overall proportion of affected animals, was used to determine significance between dosed and vehicle control groups and between the $100 \%$ OTNE and untreated control groups.

\section{Analysis of Continuous Variables}

For dosed groups compared to the vehicle control groups, two approaches were employed to assess the significance of pairwise comparisons in the analysis of continuous variables. Organ and body weight data, which historically have approximately normal distributions, were analyzed with the parametric multiple comparison procedures of Dunnett ${ }^{42}$ and Williams ${ }^{43 ; 4}$. Hematology, clinical chemistry, total microsomal protein, cytochrome P450 activity, spermatid, and epididymal spermatozoal data, which have typically skewed distributions, were analyzed using the nonparametric multiple comparison methods of Shirley ${ }^{45}$ (as modified by Williams ${ }^{46}$ ) and Dunn ${ }^{47}$. Jonckheere's test ${ }^{48}$ was used to assess the significance of the dose-related trends and to determine whether a trend-sensitive test (Williams' or Shirley's test) was more appropriate for pairwise comparisons than a test that does not assume a monotonic dose-related trend (Dunnett's or Dunn's test). Prior to statistical analysis, extreme values identified by the outlier test of Dixon and Massey ${ }^{49}$ were examined by NTP personnel, and implausible values were eliminated from the analysis. Proportions of regular cycling females in each dosed group were compared to the vehicle control group using the Fisher exact test ${ }^{41}$. Tests for extended periods of estrus, diestrus, metestrus, and proestrus, as well as skipped estrus and skipped diestrus, were constructed based on a Markov chain model proposed by Girard and Sager ${ }^{50}$. For each dose group, a transition probability matrix was estimated for transitions among the proestrus, estrus, metestrus, and diestrus stages, with provision for extended stays within each stage as well as for skipping estrus or diestrus within a cycle. Equality of transition matrices among dose groups and between the control group and each dosed group was tested using chi-square statistics.

For comparison of the $100 \%$ (neat) group to the untreated control group, a $t$-test was used to determine significant differences in organ and body weight data, and Wilcoxon's ${ }^{51}$ rank sum test was used for hematology, clinical chemistry, total microsomal protein, cytochrome P450 activity, spermatid, and epidymal spermatozoal data. Female reproductive parameters were analyzed as described for the comparison of the dosed groups to the vehicle control groups. 


\section{Quality Assurance Methods}

The 3-month studies were conducted in compliance with Food and Drug Administration Good Laboratory Practice Regulations ${ }^{52}$. In addition, as records from the 3-month studies were submitted to the NTP Archives, these studies were audited retrospectively by an independent QA contractor. Separate audits covered completeness and accuracy of the pathology data, pathology specimens, and final pathology tables. Audit procedures and findings are presented in the reports and are on file at NIEHS. The audit findings were reviewed and assessed by NTP staff, and all comments were resolved or otherwise addressed during the preparation of this Toxicity Study Report.

\section{Genetic Toxicology}

\section{Bacterial Mutagenicity Test Protocol}

Testing was performed as reported by Zeiger et al. ${ }^{53}$ in the first study, and in the second study, a slightly modified protocol was used, as described below. Both studies used the same lot (RAV0276433) of OTNE that was used in the 3-month studies. OTNE was sent to the testing laboratory as a coded sample. In the first study, it was incubated with the Salmonella typhimurium tester strains (TA98, TA100, or TA102) either in buffer or S9 mix (metabolic activation enzymes and cofactors from Aroclor 1254-induced male Sprague Dawley rats) for 20 minutes at $37^{\circ} \mathrm{C}$. Top agar supplemented with L-histidine and d-biotin was added, and the contents of the tubes were mixed and poured onto the surfaces of minimal glucose agar plates. Histidine-independent mutant colonies arising on these plates were counted following incubation for 2 days at $37^{\circ} \mathrm{C}$.

In the second study, following incubation of the bacteria with OTNE for 20 minutes at $37^{\circ} \mathrm{C}$, top agar supplemented with either L-histidine (for the Salmonella strains) or L-tryptophan (for the $E$. coli strain) and $d$-biotin was added, and the contents of the tubes were mixed and poured onto the surfaces of minimal glucose agar plates. Histidine- or tryptophan-independent mutant colonies arising on these plates were counted following incubation for 2 days at $37^{\circ} \mathrm{C}$.

In both studies, each trial consisted of triplicate plates of concurrent positive and negative controls and of at least five doses of OTNE. In the absence of toxicity, the high dose was limited by experimental design in the first study to $10,000 \mu \mathrm{g} /$ plate and in the second to $6,000 \mu \mathrm{g} / \mathrm{plate}$.

In this assay, a positive response is defined as a reproducible, dose-related increase in histidineindependent (revertant) colonies in any one strain/activation combination. An equivocal response is defined as an increase in revertants that is not dose-related, is not reproducible, or is not of sufficient magnitude to support a determination of mutagenicity. A negative response is obtained when no increase in revertant colonies is observed following chemical treatment. There is no minimum percentage or fold-increase required for a chemical to be judged positive or weakly positive.

\section{In Vivo Peripheral Blood Micronucleus Test Protocol in Rats and Mice}

The procedures used for the mouse and rat peripheral blood micronucleus assay have been described in detail ${ }^{54-56}$. Briefly, at the termination of the 3-month toxicity studies with OTNE, one to two drops of blood from male and female F344/NTac rats and male and female 
B6C3F1/N mice were collected in microtubes with EDTA and shipped on cool packs to the genetic toxicity testing laboratory for processing and fixation in ultracold methanol, as per procedures described in the MicroFlow ${ }^{\mathrm{BASIC}}$ Kit for rat blood samples or mouse blood samples (Litron Laboratories, Rochester, NY). A FACSCalibur flow cytometer (Becton Dickinson, San Jose, CA) was used to carry out the analyses of the samples. Reticulocytes were identified by the presence of an active transferrin receptor $\left(\mathrm{CD} 71^{+}\right)$on the cell surface and mature erythrocytes were CD71-negative. For the rat samples, only reticulocytes with the highest CD71 activity were evaluated due to the speed and efficiency with which the rat spleen removes damaged reticulocytes from circulation. Thus, although micronucleus frequency was evaluated in both reticulocytes and erythrocytes, the appropriate cell population for this assessment in rats is the young reticulocyte population. Micronuclei were detected using propidium iodide (a DNA stain) in conjunction with RNase treatment. Approximately $1 \times 10^{6}$ erythrocytes $\left(\mathrm{CD}^{-} 1^{-}\right)$, and 20,000 reticulocytes $\left(\mathrm{CD} 71^{+}\right)$were evaluated per animal for presence of micronuclei (propidium iodide-associated fluorescence). In addition, for each blood sample, the percentage of reticulocytes in $1 \times 10^{6}$ erythrocytes was determined as a measure of OTNE-associated bone marrow toxicity.

Approximately $1 \times 10^{6}$ erythrocytes and 20,000 reticulocytes were scored per mouse for presence of micronuclei. Based on prior experience with the large number of cells scored using flow cytometric scoring techniques ${ }^{57}$, it is reasonable to assume that the proportion of micronucleated reticulocytes is approximately normally distributed. The statistical tests selected for trend and for pairwise comparisons with the control group depend on whether the variances among the groups are equal. Levene's test at $\alpha=0.05$ is used to test for equal variances. In the case of equal variances, linear regression is used to test for a linear trend with dose and Williams' test is used to test for pairwise differences between each treatment group and the control group. In the case of unequal variances, Jonckheere's test is used to test for linear trend and Dunn's test is used for pairwise comparisons of each treatment group with the control group. To correct for multiple pairwise comparisons, the $\mathrm{P}$ value for each comparison with the control group is multiplied by the number of comparisons made. In the event that this product is greater than 1.00, it is replaced with 1.00. Trend tests and pairwise comparisons with the controls are considered statistically significant at $\mathrm{P}=0.025$. In the micronucleus assay, a positive response is preferably based on the observation of both a significant trend as well as an observation of at least one dose group significantly elevated over the concurrent control group. If only one statistical test (trend or pairwise) is significant, the micronucleus assay is judged to be equivocal. The absence of both a significant trend and a significant dose results in a negative call for the assay. Ultimately, the scientific staff determines the final call after considering the results of statistical analyses, reproducibility of any effects observed, and the magnitudes of those effects.

\section{Evaluation Protocol}

These are the basic guidelines for arriving at an overall assay result for assays performed by the National Toxicology Program. Statistical as well as biological factors are considered. For an individual assay, the statistical procedures for data analysis have been described in the preceding protocols. There have been instances, however, in which multiple samples of a chemical were tested in the same assay, and different results were obtained among these samples and/or among laboratories. Results from more than one aliquot or from more than one laboratory are not simply combined into an overall result. Rather, all the data are critically evaluated, particularly with 
regard to pertinent protocol variations, in determining the weight of evidence for an overall conclusion of chemical activity in an assay. In addition to multiple aliquots, the in vitro assays have another variable that must be considered in arriving at an overall test result. In vitro assays are conducted with and without exogenous metabolic activation. Results obtained in the absence of activation are not combined with results obtained in the presence of activation; each testing condition is evaluated separately. The Abstract of this Toxicity Study Report presents a result that represents a scientific judgment of the overall evidence for activity of the chemical in an assay. 


\section{Results}

\section{Three-month Study in Rats}

All rats survived to the end of the study (Table 3). Mean body weights and body weight gains of dosed (except $100 \%$ OTNE) males and females were similar to those of the respective control groups. The mean body weight gain of $100 \%$ OTNE males was significantly less than that of the untreated control group (Table 3 and Figure 2). There were no biologically significant clinical findings related to OTNE administration.

Table 3. Survival and Body Weights of Rats in the Three-month Dermal Study of OTNE

\begin{tabular}{|c|c|c|c|c|c|}
\hline Dose (\%) & Survival $^{\text {b }}$ & $\begin{array}{c}\text { Initial Body } \\
\text { Weight (g) }\end{array}$ & $\begin{array}{l}\text { Final Body } \\
\text { Weight (g) }\end{array}$ & $\begin{array}{l}\text { Change in Body } \\
\text { Weight (g) }\end{array}$ & $\begin{array}{l}\text { Final Weight } \\
\text { Relative to } \\
\text { Controls }(\%)\end{array}$ \\
\hline \multicolumn{6}{|l|}{ Male } \\
\hline Untreated control & $10 / 10$ & $86 \pm 2$ & $324 \pm 6$ & $239 \pm 6$ & \\
\hline Vehicle control & $10 / 10$ & $85 \pm 2$ & $318 \pm 6$ & $233 \pm 5$ & \\
\hline 6.25 & $10 / 10$ & $83 \pm 2$ & $308 \pm 9$ & $225 \pm 9$ & 97 \\
\hline 12.5 & $10 / 10$ & $83 \pm 2$ & $293 \pm 5$ & $210 \pm 5$ & 92 \\
\hline 25 & $10 / 10$ & $84 \pm 2$ & $307 \pm 8$ & $223 \pm 7$ & 97 \\
\hline 50 & $10 / 10$ & $83 \pm 2$ & $302 \pm 7$ & $219 \pm 7$ & 95 \\
\hline 100 & $10 / 10$ & $86 \pm 2$ & $306 \pm 7$ & $219 \pm 7^{\dagger}$ & 94 \\
\hline \multicolumn{6}{|l|}{ Female } \\
\hline Untreated control & $10 / 10$ & $82 \pm 2$ & $184 \pm 4$ & $102 \pm 3$ & \\
\hline Vehicle control & $10 / 10$ & $83 \pm 1$ & $187 \pm 3$ & $104 \pm 2$ & \\
\hline 6.25 & $10 / 10$ & $82 \pm 2$ & $188 \pm 2$ & $106 \pm 2$ & 101 \\
\hline 12.5 & $10 / 10$ & $83 \pm 2$ & $184 \pm 4$ & $102 \pm 4$ & 99 \\
\hline 25 & $10 / 10$ & $84 \pm 1$ & $187 \pm 4$ & $103 \pm 3$ & 100 \\
\hline 50 & $10 / 10$ & $83 \pm 1$ & $184 \pm 3$ & $101 \pm 2$ & 99 \\
\hline 100 & $10 / 10$ & $82 \pm 2$ & $180 \pm 3$ & $98 \pm 2$ & 98 \\
\hline
\end{tabular}

${ }^{\dagger}$ Significantly different $(\mathrm{P} \leq 0.05)$ from the untreated control group by a t-test.

${ }^{a}$ Weights and weight changes are given as mean \pm standard error. Differences between the $6.25 \%, 12.5 \%, 25 \%$, and $50 \%$ OTNE groups and the vehicle control groups are not significant by Dunnett's test. Statistical comparisons between the two control groups are not presented.

${ }^{b}$ Number of animals surviving to the end of the study/number initially in group.

'Dosed groups are compared to the vehicle control groups, except 100\% OTNE groups are compared to the untreated control groups. 



Figure 2. Growth Curves for Rats Exposed to OTNE by Dermal Application for Three Months

There were no changes in the hematology parameters attributable to the dermal administration of OTNE (Table B-1). Serum alkaline phosphatase activities were decreased in various male and female dosed groups at all time points (days 3 and 23 and week 13). While this change was not always observed in the lower dosed groups, decreases were consistently observed in $100 \%$ OTNE males and females at all time points compared to the untreated control groups. At the end of the study (week 13), alanine aminotransferase activities were decreased in $25 \%$ OTNE or greater females and in all dosed groups of males compared to their respective control groups. 
The significance of these decreases is not known but may be related to an alteration in liver metabolism. Other changes in clinical chemistry results were not considered toxicologically or biologically relevant.

Mean microsomal protein yields and cytochrome P4502E1 (Cyp2e1) activities were measured on day 23 and at the end of the study (week 13) to distinguish between ethanol-related liver effects and the treatment-related effects of OTNE (Table B-2). Microsomal protein was significantly increased (up to $44 \%$ ) at the end of the study in females from the $12.5 \%$ to $100 \%$ OTNE groups when compared to their respective controls. Microsomal protein (males) at week 13 and Cyp2el activities in the males and females were not statistically different from controls.

Absolute and relative liver weights were significantly greater (up to 30\%) in the males and females of the 50\% and 100\% OTNE groups (except for the absolute liver weight of 50\% males) with respect to their controls (Table 4 and Table C-1). Relative kidney weights were significantly increased by approximately $9 \%$ in the male and female rats of the 100\% OTNE groups compared to untreated controls (Table C-1). Treatment-related histopathologic changes were not observed in the liver or kidney of males or females (Table A-1 and Table A-2).

Male rats did not display any OTNE-related changes in testis and epididymis weights or sperm parameters (Table D-1). Female rats administered OTNE did not display any toxicologically significant effects on cycle length, or estrous cyclicity (Table D-2).

Table 4. Liver Weights and Liver-Weight-to-Body-Weight Ratios for Rats in the Three-month Dermal Study of OTNE ${ }^{a}$

\begin{tabular}{|c|c|c|c|c|c|c|c|}
\hline & $\begin{array}{c}\text { Untreated } \\
\text { Control }\end{array}$ & $\begin{array}{l}\text { Vehicle } \\
\text { Control }\end{array}$ & $6.25 \%$ & $12.5 \%$ & $25 \%$ & $50 \%$ & $100 \%$ \\
\hline n & 10 & 10 & 10 & 10 & 10 & 10 & 10 \\
\hline \multicolumn{8}{|l|}{ Male } \\
\hline $\begin{array}{l}\text { Necropsy } \\
\text { body wt }\end{array}$ & $324 \pm 6$ & $318 \pm 6$ & $308 \pm 9$ & $293 \pm 5$ & $307 \pm 8$ & $302 \pm 7$ & $306 \pm 7$ \\
\hline \multicolumn{8}{|l|}{ Liver } \\
\hline Absolute & $13.62 \pm 0.54$ & $13.60 \pm 0.48$ & $12.81 \pm 0.44$ & $12.73 \pm 0.50$ & $13.33 \pm 0.46$ & $14.57 \pm 0.74$ & $15.93 \pm 0.65^{\dagger}$ \\
\hline Relative & $41.95 \pm 1.17$ & $42.77 \pm 1.16$ & $41.62 \pm 0.95$ & $43.55 \pm 1.84$ & $43.48 \pm 1.38$ & $48.04 \pm 1.64^{*}$ & $52.12 \pm 1.83^{\dagger \dagger}$ \\
\hline \multicolumn{8}{|l|}{ Female } \\
\hline $\begin{array}{l}\text { Necropsy } \\
\text { body wt }\end{array}$ & $184 \pm 4$ & $187 \pm 3$ & $188 \pm 2$ & $184 \pm 4$ & $187 \pm 4$ & $184 \pm 3$ & $180 \pm 3$ \\
\hline \multicolumn{8}{|l|}{ Liver } \\
\hline Absolute & $6.50 \pm 0.33$ & $6.99 \pm 0.21$ & $6.89 \pm 0.19$ & $7.09 \pm 0.27$ & $7.51 \pm 0.20$ & $7.78 \pm 0.27 * b$ & $8.24 \pm 0.18^{\dagger \dagger}$ \\
\hline Relative & $35.29 \pm 1.42$ & $37.44 \pm 0.67$ & $36.60 \pm 0.92$ & $38.52 \pm 1.40$ & $40.09 \pm 0.65$ & $41.93 \pm 1.35^{* * \mathrm{~b}}$ & $46.29 \pm 1.02^{\dagger \dagger}$ \\
\hline
\end{tabular}

*Significantly different $(\mathrm{P} \leq 0.05)$ from the vehicle control group by Dunnett's or Williams' test.

$* * \mathrm{P} \leq 0.01$.

${ }^{\dagger}$ Significantly different $(\mathrm{P} \leq 0.05)$ from the untreated control group by a $t$-test.

${ }^{\dagger} \mathrm{P} \leq 0.01$.

${ }^{a}$ Liver weights (absolute weights) and body weights are given in grams; liver-weight-to-body-weight ratios (relative weights) are given as $\mathrm{mg}$ liver weight/g body weight (mean \pm standard error). Statistical comparisons between the two control groups are not presented.

${ }^{b} n=9$. 
In males and females administered $12.5 \%$ to $50 \%$ OTNE, the incidences of minimal to mild hyperplasia and hyperkeratosis (except $12.5 \%$ OTNE males) in the skin (site of application) were significantly greater than those of the vehicle control groups; the incidences of these lesions in $100 \%$ OTNE males and females were significantly greater than the untreated control incidences (Table 5, Table A-1, and Table A-2). Hyperplasia was characterized by variably thickened epidermis compared to that of the controls (Figure 4 and Figure 5) due to increased numbers of basal, squamous, and/or granular epidermal cells (Figure 6 and Figure 7). Hyperplasia was graded by the following criteria: minimal ( 2 to 3 cell layers thick); mild ( 3 to 4 cell layers thick); moderate ( $>5$ cell layers thick without rete pegs); and marked ( $>5$ cell layers thick with rete pegs). Hyperkeratosis was characterized by the presence of subtle to minimal compressed keratin overlying the stratum granulosum (Figure 6 and Figure 7).

Table 5. Incidences of Nonneoplastic Lesions of the Skin (Site of Application) in Rats in the Threemonth Dermal Study of OTNE ${ }^{\text {a }}$

\begin{tabular}{|c|c|c|c|c|c|c|c|}
\hline & $\begin{array}{c}\text { Untreated } \\
\text { Control }\end{array}$ & $\begin{array}{l}\text { Vehicle } \\
\text { Control }\end{array}$ & $6.25 \%$ & $12.5 \%$ & $25 \%$ & $50 \%$ & $100 \%$ \\
\hline \multicolumn{8}{|l|}{ Male } \\
\hline $\begin{array}{l}\text { Number Examined } \\
\text { Microscopically }\end{array}$ & 10 & 10 & 10 & 10 & 10 & 10 & 10 \\
\hline Hyperkeratosis ${ }^{\mathrm{b}}$ & 0 & 0 & $1(1.0)^{\mathrm{c}}$ & $3(1.0)$ & $4 *(1.0)$ & $5^{*}(1.0)$ & $8^{\dagger \dagger}(1.1)$ \\
\hline Hyperplasia & 0 & 0 & $2(1.0)$ & $4 *(1.0)$ & $5^{*}(1.0)$ & $8 * *(1.5)$ & $10^{\dagger \dagger}(1.3)$ \\
\hline \multicolumn{8}{|l|}{ Female } \\
\hline $\begin{array}{l}\text { Number Examined } \\
\text { Microscopically }\end{array}$ & 10 & 10 & 10 & 10 & 10 & 10 & 10 \\
\hline Hyperkeratosis & 0 & 0 & 0 & $4 *(1.0)$ & $5^{*}(1.4)$ & $7 * *(1.3)$ & $7^{\dagger \dagger}(1.9)$ \\
\hline Hyperplasia & 0 & 0 & $1(1.0)$ & $5 *(1.0)$ & $7 * *(1.3)$ & $7 * *(1.4)$ & $8^{\dagger \dagger}(1.9)$ \\
\hline
\end{tabular}

*Significantly different $(\mathrm{P} \leq 0.05)$ from the vehicle control group by the Fisher exact test.

$* * \mathrm{P} \leq 0.01$.

${ }^{\dagger}$ Significantly different $(\mathrm{P} \leq 0.01)$ from the untreated control group by the Fisher exact test.

${ }^{a}$ Statistical comparisons between the two control groups are not presented.

${ }^{b}$ Number of animals with lesion.

${ }^{\mathrm{c}}$ Average severity grade of lesions in affected animals: $1=$ minimal, $2=$ mild, $3=$ moderate, $4=$ marked .

\section{Three-month Study in Mice}

All mice survived to the end of the study (Table 6). The final mean body weights of $6.25 \%, 25 \%$, and 50\% OTNE males and mean body weight gains of $6.25 \%$ and $25 \%$ OTNE males were significantly less than those of the vehicle control group; those of $100 \%$ OTNE males were significantly less than those of the untreated controls (Table 6 and Figure 3). Clinically, irritation was observed in the skin (site of application) of four males and two females administered $50 \%$ OTNE and in all males and females administered 100\% OTNE. In addition, lesions considered to be ulcers were observed at the site of application in five males and two females administered 100\% OTNE; these lesions were observed between day 43 in males and day 57 in females until the end of the study. 
OTNE, NTP TOX 92

Table 6. Survival and Body Weights of Mice in the Three-month Dermal Study of OTNE

\begin{tabular}{|c|c|c|c|c|c|}
\hline Dose $(\%)$ & Survival $^{b}$ & $\begin{array}{l}\text { Initial Body } \\
\text { Weight (g) }\end{array}$ & $\begin{array}{l}\text { Final Body } \\
\text { Weight (g) }\end{array}$ & $\begin{array}{l}\text { Change in Body } \\
\text { Weight }(\mathrm{g})\end{array}$ & $\begin{array}{l}\text { Final Weight } \\
\text { Relative to } \\
\text { Controls }(\%)\end{array}$ \\
\hline \multicolumn{6}{|l|}{ Male } \\
\hline Untreated control & $10 / 10$ & $23.1 \pm 0.6$ & $37.7 \pm 1.2$ & $14.6 \pm 1.1$ & \\
\hline Vehicle control & $10 / 10$ & $23.7 \pm 0.2$ & $35.0 \pm 0.6$ & $11.3 \pm 0.6$ & \\
\hline 6.25 & $10 / 10$ & $22.9 \pm 0.3$ & $32.2 \pm 0.4 * *$ & $9.3 \pm 0.3^{*}$ & 92 \\
\hline 12.5 & $10 / 10$ & $23.4 \pm 0.3$ & $33.7 \pm 1.0$ & $10.3 \pm 0.8$ & 96 \\
\hline 25 & $10 / 10$ & $22.6 \pm 0.3$ & $32.0 \pm 0.4 * *$ & $9.4 \pm 0.3^{*}$ & 92 \\
\hline 50 & $10 / 10$ & $22.8 \pm 0.5$ & $32.5 \pm 0.5^{*}$ & $9.6 \pm 0.4$ & 93 \\
\hline 100 & $10 / 10$ & $23.1 \pm 0.2$ & $32.2 \pm 0.4^{\dagger \dagger}$ & $9.1 \pm 0.4 \dagger$ & 86 \\
\hline \multicolumn{6}{|l|}{ Female } \\
\hline Untreated control & $10 / 10$ & $18.6 \pm 0.3$ & $28.5 \pm 0.7$ & $9.9 \pm 0.5$ & \\
\hline Vehicle control & $10 / 10$ & $19.1 \pm 0.6$ & $29.5 \pm 0.7$ & $10.4 \pm 0.5$ & \\
\hline 6.25 & $10 / 10$ & $18.8 \pm 0.3$ & $30.1 \pm 0.7$ & $11.3 \pm 0.7$ & 102 \\
\hline 12.5 & $10 / 10$ & $18.8 \pm 0.2$ & $29.2 \pm 0.6$ & $10.4 \pm 0.5$ & 99 \\
\hline 25 & $10 / 10$ & $18.5 \pm 0.2$ & $28.9 \pm 0.3$ & $10.4 \pm 0.3$ & 98 \\
\hline 50 & $10 / 10$ & $18.4 \pm 0.3$ & $29.2 \pm 0.4$ & $10.8 \pm 0.4$ & 99 \\
\hline 100 & $10 / 10$ & $18.4 \pm 0.2$ & $29.4 \pm 0.3$ & $11.1 \pm 0.3$ & 103 \\
\hline
\end{tabular}

*Significantly different $(\mathrm{P} \leq 0.05)$ from the vehicle control group by Dunnett's test.

$* * \mathrm{P} \leq 0.01$.

${ }^{\dagger}$ Significantly different $(\mathrm{P} \leq 0.01)$ from the untreated control group by a t-test.

${ }^{a}$ Weights and weight changes are given as mean \pm standard error. Statistical comparisons between the two control groups are not presented.

${ }^{b}$ Number of animals surviving at the end of the study/number initially in group.

${ }^{\mathrm{c}}$ Dosed groups are compared to the vehicle control groups, except 100\% OTNE groups are compared to the untreated control groups. 

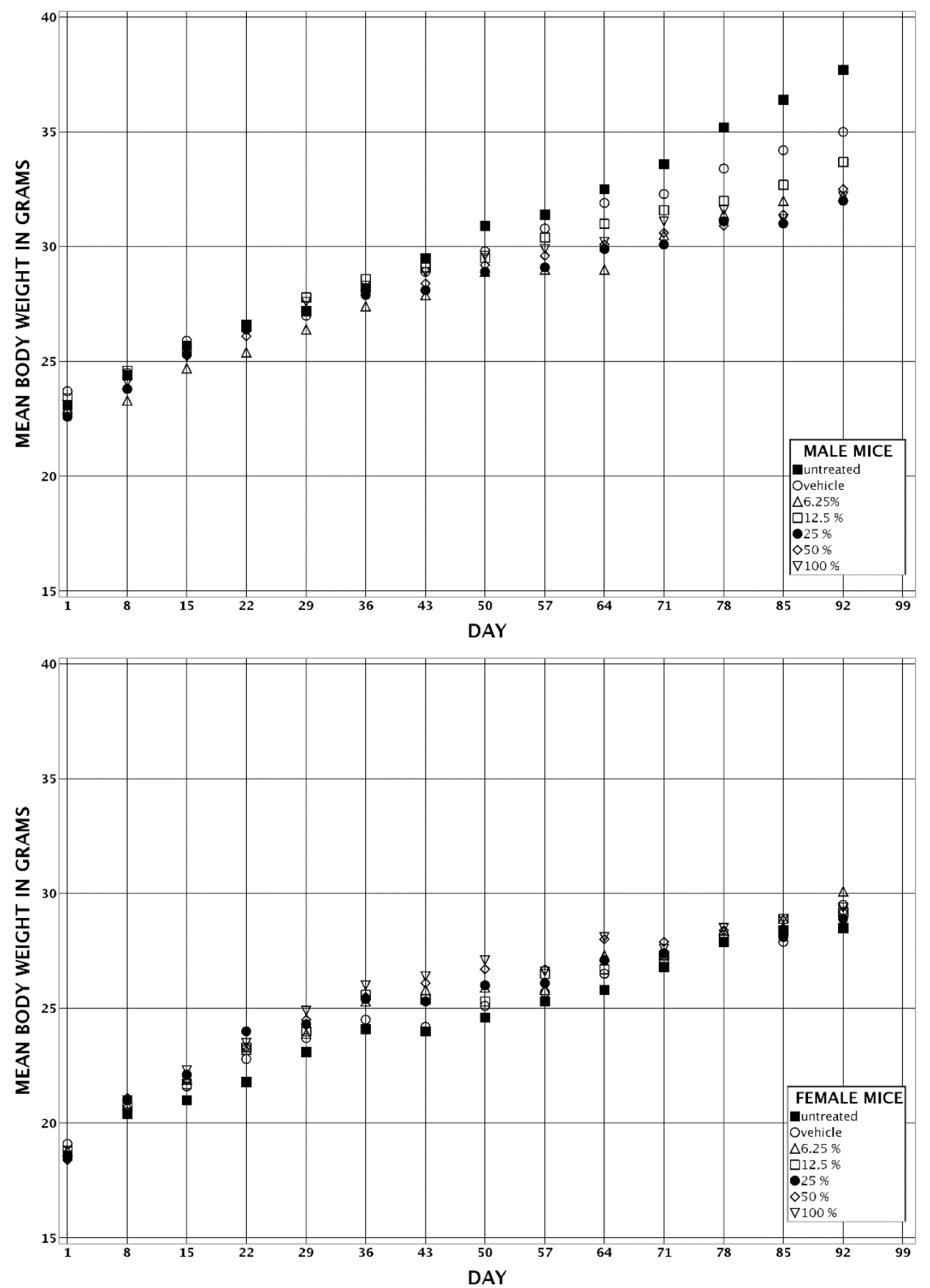

Figure 3. Growth Curves for Mice Exposed to OTNE by Dermal Application for Three Months

When compared to the vehicle (dosed groups) or untreated (100\% OTNE groups) controls, significant decreases $(\leq 14 \%)$ in the erythrocyte counts, hemoglobin concentrations, and hematocrit values occurred in the 25\% OTNE or greater males and 100\% OTNE females (Table B-3). Erythrocyte distribution widths, coefficients of variation of erythrocyte volumes (i.e., increased values indicate increased variation in sizes), were significantly increased in the $25 \%$ OTNE or greater males and in all dosed groups of females compared to their respective 
control groups. The parameters of erythrocyte count, hemoglobin concentration, and hematocrit value are quantitative estimates of the circulating erythroid mass. The changes in these parameters, paired with the changes in the red cell distribution width, were consistent with an alteration in erythropoiesis. Other changes in the erythron were not considered toxicologically or biologically relevant.

In male and female vehicle control mice at the end of the study, there was no effect on CYP2E1 activity relative to the untreated controls (Table B-4). This suggests that the vehicle itself did not affect liver function. However, male and female mice did exhibit dose-dependent increases in CYP2E1 activity. Male mice treated with $25 \%, 50 \%$, or $100 \%$ OTNE had significantly increased CYP2E1 activities (ranging from 35\% to 80\%) when compared to their respective control groups. CYP2E1 activity was also significantly increased (ranging from $26 \%$ to $65 \%$ ) in all female groups administered OTNE compared to their respective control groups. These increases in CYP2E1 activity were less than twofold and not considered biologically relevant.

Absolute and relative organ weights were significantly changed in male and female mice. Absolute liver weights of all female and all male dosed groups (except 6.25\% OTNE males) were increased (up to 92\%) compared to their respective controls (Table 7 and Table C-2). Similarly, the relative liver weights of all male and female dosed groups were increased (up to 89\%) compared to their respective controls. Absolute and relative heart weights were increased approximately $14 \%$ in the $50 \%$ and $100 \%$ OTNE females; the relative heart weights of $25 \%$ and $100 \%$ OTNE males were also increased, but this may be due to the decreased body weights noted in the males (Table 6 and Table C-2). The absolute thymus weights of males and females as well as the relative thymus weight of females were decreased by approximately $22 \%$ in the $100 \%$ OTNE groups compared to untreated controls (Table C-2). In males, the absolute testis weight was decreased by $10 \%$ in the $50 \%$ OTNE group. In females, the relative lung weight of the $100 \%$ OTNE group was decreased by $21 \%$ compared to untreated controls. Histopathologic changes were not associated with alterations in organ weights, with the exception of centrilobular hypertrophy noted in 100\% OTNE males (Table A-3, Table A-4, and Table C-2).

Male mice administered 100\% OTNE displayed fewer caudal sperm and caudal sperm/mg; these findings were not associated with any histopathologic changes in the testes or epididymides (Table 8, Table A-3, and Table D-3). Male mice in the 100\% OTNE group also exhibited lower sperm motility $(\sim 11 \%)$ (Table 8 and Table D-3).

Female mice administered 100\% OTNE exhibited an increase in cycle length of approximately 1 day and displayed an increased probability of extended estrus as compared to the untreated controls (Table 9 and Table D-4). The increased probability of extended estrus was also observed in the $25 \%$ and $50 \%$ OTNE groups as compared to the vehicle controls. When displayed as days in any given stage and presented as a percentage, the 25\%, 50\%, and 100\% OTNE groups exhibited more time in estrus than the respective control groups. 
OTNE, NTP TOX 92

Table 7. Liver Weights and Liver-Weight-to-Body-Weight Ratios for Mice in the Three-month Dermal Study of OTNE

\begin{tabular}{|c|c|c|c|c|c|c|c|}
\hline & $\begin{array}{c}\text { Untreated } \\
\text { Control }\end{array}$ & Vehicle Control & $6.25 \%$ & $12.5 \%$ & $25 \%$ & $50 \%$ & $100 \%$ \\
\hline $\mathbf{n}$ & 10 & 10 & 10 & 10 & 10 & 10 & 10 \\
\hline \multicolumn{8}{|l|}{ Male } \\
\hline Necropsy body wt & $37.7 \pm 1.2$ & $35.0 \pm 0.6$ & $32.2 \pm 0.4 * *$ & $33.7 \pm 1.0$ & $32.0 \pm 0.4^{* *}$ & $32.5 \pm 0.5 *$ & $32.2 \pm 0.4^{\dagger \dagger}$ \\
\hline \multicolumn{8}{|l|}{ Liver } \\
\hline Absolute & $1.64 \pm 0.05$ & $1.60 \pm 0.05$ & $1.68 \pm 0.07$ & $1.82 \pm 0.09 *$ & $1.99 \pm 0.09 * *$ & $2.12 \pm 0.03^{* *}$ & $2.66 \pm 0.07^{\dagger \dagger}$ \\
\hline Relative & $43.79 \pm 1.34$ & $45.72 \pm 1.29$ & $51.98 \pm 1.96^{*}$ & $54.09 \pm 2.20^{* *}$ & $62.10 \pm 2.99 * *$ & $65.35 \pm 1.52 * *$ & $82.51 \pm 1.92^{\dagger \dagger}$ \\
\hline \multicolumn{8}{|l|}{ Female } \\
\hline Necropsy body wt & $28.5 \pm 0.7$ & $29.5 \pm 0.7$ & $30.1 \pm 0.7$ & $29.2 \pm 0.6$ & $28.9 \pm 0.3$ & $29.2 \pm 0.4$ & $29.4 \pm 0.3$ \\
\hline \multicolumn{8}{|l|}{ Liver } \\
\hline Absolute & $1.28 \pm 0.04$ & $1.37 \pm 0.05$ & $1.52 \pm 0.04 *$ & $1.65 \pm 0.04 * *$ & $1.69 \pm 0.03 * *$ & $2.04 \pm 0.05 * *$ & $2.46 \pm 0.07^{\dagger \dagger}$ \\
\hline Relative & $45.04 \pm 1.03$ & $46.48 \pm 1.46$ & $50.45 \pm 0.76^{*}$ & $56.53 \pm 1.22 * *$ & $58.35 \pm 0.61 * *$ & $69.96 \pm 1.26 * *$ & $83.54 \pm 2.31^{\dagger \dagger}$ \\
\hline
\end{tabular}

*Significantly different $(\mathrm{P} \leq 0.05)$ from the vehicle control group by Dunnett's or Williams' test.

$* * \mathrm{P} \leq 0.01$.

${ }^{\dagger}$ Significantly different $(\mathrm{P} \leq 0.01)$ from the untreated control group by a t-test.

${ }^{a}$ Liver weights (absolute weights) and body weights are given in grams; liver-weight-to-body-weight ratios (relative weights) are given as mg liver weight/g body weight

(mean \pm standard error). Statistical comparisons between the two control groups are not presented. 
OTNE, NTP TOX 92

Table 8. Summary of Reproductive Tissue Evaluations for Male Mice in the Three-month Dermal Study of OTNE

\begin{tabular}{|c|c|c|c|c|c|}
\hline & Untreated Control & Vehicle Control & $25 \%$ & $50 \%$ & $100 \%$ \\
\hline $\mathbf{n}$ & 9 & 10 & 7 & 7 & 10 \\
\hline \multicolumn{6}{|l|}{ Weights (g) } \\
\hline Necropsy body wt & $37.8 \pm 1.3$ & $35.0 \pm 0.6$ & $32.2 \pm 0.5 * *$ & $32.9 \pm 0.5^{*}$ & $32.2 \pm 0.4^{\dagger \dagger}$ \\
\hline L. Cauda epididymis & $0.0210 \pm 0.0015$ & $0.0196 \pm 0.0011$ & $0.0218 \pm 0.0017$ & $0.0252 \pm 0.0041$ & $0.0170 \pm 0.0012^{\dagger}$ \\
\hline L. Epididymis & $0.0515 \pm 0.0040$ & $0.0480 \pm 0.0023$ & $0.0615 \pm 0.0068$ & $0.0549 \pm 0.0040$ & $0.0435 \pm 0.0021$ \\
\hline L. Testis & $0.1119 \pm 0.0022$ & $0.1119 \pm 0.0016$ & $0.1114 \pm 0.0041$ & $0.1085 \pm 0.0038$ & $0.1052 \pm 0.0025$ \\
\hline \multicolumn{6}{|l|}{ Spermatid measurements } \\
\hline Spermatid heads $\left(10^{6} / \mathrm{g}\right.$ testis) & $214.10 \pm 17.77$ & $233.47 \pm 16.49$ & $252.91 \pm 18.67$ & $254.21 \pm 16.20$ & $234.12 \pm 21.35$ \\
\hline Spermatid heads $\left(10^{6} /\right.$ testis $)$ & $23.93 \pm 1.97$ & $26.21 \pm 2.10$ & $27.93 \pm 1.79$ & $27.57 \pm 2.00$ & $24.80 \pm 2.40$ \\
\hline \multicolumn{6}{|c|}{ Epididymal spermatozoal measurements } \\
\hline Sperm motility (\%) & $90.8 \pm 2.2$ & $94.7 \pm 0.8$ & $91.0 \pm 3.6$ & $92.4 \pm 1.9$ & $80.6 \pm 7.4$ \\
\hline $\begin{array}{l}\text { Sperm }\left(10^{6} / g \text { cauda }\right. \\
\text { epididymis })\end{array}$ & $169.9 \pm 21.6$ & $151.1 \pm 11.2$ & $144.3 \pm 8.9$ & $153.9 \pm 29.2$ & $112.2 \pm 22.4$ \\
\hline Sperm (10\% cauda epididymis) & $3.4 \pm 0.3$ & $2.9 \pm 0.2$ & $3.2 \pm 0.4$ & $3.5 \pm 0.7$ & $1.8 \pm 0.3^{\dagger \dagger}$ \\
\hline \multicolumn{6}{|c|}{ 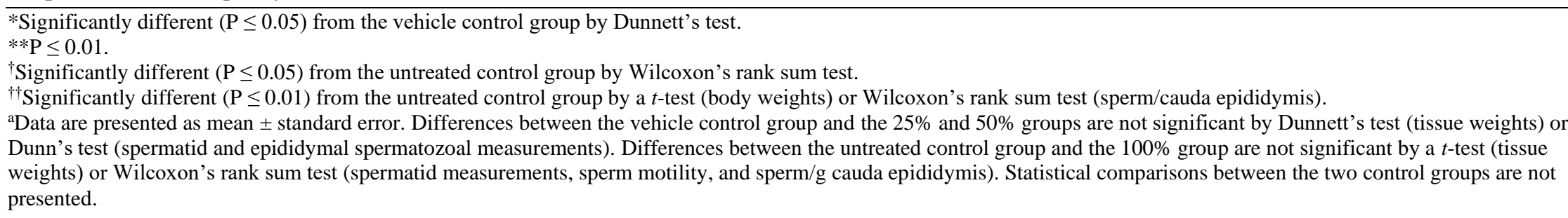 } \\
\hline
\end{tabular}


OTNE, NTP TOX 92

Table 9. Estrous Cycle Characterization for Female Mice in the Three-month Dermal Study of OTNE

\begin{tabular}{|c|c|c|c|c|c|}
\hline & Untreated Control & Vehicle Control & $25 \%$ & $\mathbf{5 0 \%}$ & $100 \%$ \\
\hline Number weighed at necropsy & 10 & 10 & 10 & 10 & 10 \\
\hline Necropsy body wt (g) & $28.5 \pm 0.7$ & $29.5 \pm 0.7$ & $28.9 \pm 0.3$ & $29.2 \pm 0.4$ & $29.4 \pm 0.3$ \\
\hline Proportion of regular cycling females ${ }^{b}$ & $9 / 10$ & $10 / 10$ & $10 / 10$ & $10 / 10$ & $9 / 10$ \\
\hline Estrous cycle length (days) & $4.0 \pm 0.2$ & $4.5 \pm 0.2$ & $4.6 \pm 0.2$ & $4.5 \pm 0.2$ & $5.2 \pm 0.3^{\dagger+}$ \\
\hline \multicolumn{6}{|l|}{ Estrous stages (\% of cycle) } \\
\hline Diestrus & 38.8 & 38.8 & 31.3 & 33.8 & 37.5 \\
\hline Proestrus & 0.0 & 0.0 & 1.3 & 0.6 & 0.0 \\
\hline Estrus & 38.1 & 43.1 & 51.3 & 56.3 & 53.1 \\
\hline Metestrus & 15.0 & 11.9 & 10.0 & 6.3 & 6.9 \\
\hline Uncertain diagnosis & 8.1 & 6.3 & 6.3 & 3.1 & 2.5 \\
\hline
\end{tabular}

$\pitchfork$ Significantly different $(\mathrm{P} \leq 0.01)$ from the untreated control group by Dunn's test.

${ }^{a}$ Necropsy body weights and estrous cycle length data are presented as mean \pm standard error. Differences between the vehicle control group and the $25 \%$ and $50 \%$ groups are not significant by Dunnett's test (body weights) or Dunn's test (estrous cycle length). Differences between the untreated control group and the $100 \%$ group are not significant by a $t$ test (body weights). By multivariate analysis of variance, dosed females do not differ significantly from the vehicle control females in the relative length of time spent in the estrous stages. Tests for equality of transition probability matrices among all groups and between the respective control group and each dosed group indicated the probability of extended estrus was significantly higher in the dose groups than the respective control groups. Statistical comparisons between the two control groups are not presented. ${ }^{b}$ Number of females with a regular cycle/number of females cycling. 
Compared to occurrences in the respective control groups, the incidences of several nonneoplastic lesions of the skin were significantly increased in dosed groups of males and females (Table 10, Table A-3, and Table A-4). At the site of application, the incidences of minimal to moderate hyperplasia and chronic active inflammation were significantly increased in all dosed groups of males and females. The incidences of minimal to mild hyperkeratosis were significantly increased in males administered $12.5 \%$ OTNE or greater and in all dosed groups of females. The incidences of fibrosis were significantly increased in all dosed groups of males except the $12.5 \%$ OTNE group, and in females administered $12.5 \%$ OTNE or greater. The incidences of epidermis suppurative inflammation were significantly increased in 100\% OTNE males and in females administered 25\% OTNE or greater. The incidences of hair follicle hyperplasia were significantly increased in 50\% and 100\% OTNE males and females administered $25 \%$ OTNE or greater.

In the skin adjacent to the site of application, the incidences of hyperplasia, hyperkeratosis, chronic active inflammation, fibrosis, and epidermis suppurative inflammation were significantly increased in 100\% OTNE males and females, and the incidence of hair follicle hyperplasia was significantly increased in 100\% OTNE males (Table 10, Table A-3, and Table A-4). The incidences of these lesions were also increased in most of the lower dosed groups of both sexes, sometimes significantly; these lesions were considered secondary to the spread of the test material from the site of application rather than a systemic effect. Lesions were not observed in examined control skin of male or female mice.

Compared to the vehicle controls (Figure 8 and Figure 9), hyperplasia and hyperkeratosis (Figure 10, Figure 11, and Figure 12) in the skin (site of application) were histologically similar to these lesions described in the rat; the same grading criteria were applied. Chronic active inflammation was characterized by increased numbers of scattered neutrophils, lymphocytes, and macrophages in the superficial dermis; increased numbers of mast cells and/or melanocytes were noted (Figure 11 and Figure 13). Fibrosis was characterized by replacement of the normally present dermal collagen fibers by discrete bands of pale basophilic fibrous connective tissue and/or increased numbers of fibroblasts (Figure 12 and Figure 13). Suppurative inflammation of the epidermis was characterized by discrete aggregates of degenerate neutrophils (pustules) within the stratum corneum and less frequently, hair follicles (Figure 12 and Figure 13). Hair follicle hyperplasia was characterized by increased numbers of follicle profiles and often the associated adnexal structures (e.g., sebaceous glands) within the dermis (Figure 10 to Figure 13).

In the liver, the incidence of centrilobular hypertrophy in 100\% OTNE males was significantly greater than that in the untreated controls (Table 10 and Table A-3). There were no hepatic lesions in female mice. Centrilobular hypertrophy was of mild severity; affected hepatocytes were larger than the surrounding hepatocytes and had increased amounts of lightly eosinophilic to granular cytoplasm and loss of cytoplasmic glycogen. 
OTNE, NTP TOX 92

Table 10. Incidences of Selected Nonneoplastic Lesions in Mice in the Three-month Dermal Study of OTNE

\begin{tabular}{|c|c|c|c|c|c|c|c|}
\hline & $\begin{array}{c}\text { Untreated } \\
\text { Control } \\
\end{array}$ & $\begin{array}{l}\text { Vehicle } \\
\text { Control } \\
\end{array}$ & $6.25 \%$ & $12.5 \%$ & $25 \%$ & $\mathbf{5 0 \%}$ & $100 \%$ \\
\hline \multicolumn{8}{|l|}{ Male } \\
\hline Skin, Site of Application ${ }^{\mathrm{b}}$ & 10 & 10 & 10 & 10 & 10 & 9 & 10 \\
\hline Fibrosis $^{\mathrm{c}}$ & 0 & 0 & $4^{*}(1.5)^{\mathrm{d}}$ & $3(2.0)$ & $8 * *(1.8)$ & $8 * *(1.6)$ & $10^{\dagger \dagger}(2.0)$ \\
\hline Hyperkeratosis & 0 & 0 & $2(1.0)$ & $5 *(1.4)$ & $5^{*}(1.4)$ & $8 * *(1.4)$ & $10^{\dagger \dagger}(1.7)$ \\
\hline Hyperplasia & 0 & 0 & $9 * *(1.7)$ & $10 * *(1.9)$ & $9 * *(1.8)$ & $9 * *(2.3)$ & $10^{\dagger \dagger}(2.8)$ \\
\hline $\begin{array}{l}\text { Inflammation, } \\
\text { Chronic Active }\end{array}$ & 0 & 0 & $7 * *(1.4)$ & $10^{* *}(1.7)$ & $9 * *(1.7)$ & $9 * *(1.7)$ & $10^{\dagger \dagger}(2.0)$ \\
\hline $\begin{array}{l}\text { Epidermis, Inflammation, } \\
\text { Suppurative }\end{array}$ & 0 & 0 & 0 & 0 & $1(1.0)$ & $1(2.0)$ & $5^{\dagger}(1.0)$ \\
\hline Hair Follicle, Hyperplasia & 0 & 0 & $3(1.0)$ & $2(1.5)$ & $3(2.3)$ & $7 * *(1.1)$ & $8^{\dagger \dagger}(1.8)$ \\
\hline $\begin{array}{l}\text { Skin Adjacent to the } \\
\text { Site of Application }\end{array}$ & 10 & 10 & 10 & 10 & 9 & 10 & 10 \\
\hline Fibrosis & 0 & 0 & 0 & 0 & $1(1.0)$ & $2(1.5)$ & $5^{\dagger}(1.4)$ \\
\hline Hyperkeratosis & 0 & 0 & 0 & 0 & 0 & $2(2.0)$ & $5^{\dagger}(1.6)$ \\
\hline Hyperplasia & 0 & 0 & 0 & $2(1.5)$ & $4^{*}(1.0)$ & $3(2.0)$ & $8^{\dagger \dagger}(2.3)$ \\
\hline $\begin{array}{l}\text { Inflammation, } \\
\text { Chronic Active }\end{array}$ & 0 & 0 & 0 & $2(1.5)$ & $4 *(1.3)$ & $2(2.0)$ & $8^{\dagger \dagger}(1.8)$ \\
\hline $\begin{array}{l}\text { Epidermis, Inflammation, } \\
\text { Suppurative }\end{array}$ & 0 & 0 & 0 & 0 & 0 & $1(2.0)$ & $4^{\dagger}(1.0)$ \\
\hline Hair Follicle, Hyperplasia & 0 & 0 & 0 & $1(2.0)$ & 0 & $1(2.0)$ & $5^{\dagger}(1.6)$ \\
\hline Liver & 10 & 10 & 10 & 10 & 9 & 10 & 10 \\
\hline Centrilobular, Hypertrophy & 0 & $1(3.0)$ & 0 & $2(1.0)$ & $3(1.3)$ & 0 & $4^{\dagger}(2.0)$ \\
\hline \multicolumn{8}{|l|}{ Female } \\
\hline Skin, Site of Application & 10 & 10 & 10 & 10 & 10 & 6 & 10 \\
\hline Fibrosis & 0 & 0 & $2(1.5)$ & $10^{* *}(1.6)$ & $10 * *(1.7)$ & $4 * *(1.3)$ & $9^{\dagger \dagger}(2.0)$ \\
\hline Hyperkeratosis & 0 & 0 & $5 *(1.2)$ & $5 *(1.2)$ & $10 * *(1.7)$ & $6^{* *}(1.8)$ & $10^{\dagger \dagger}(2.1)$ \\
\hline Hyperplasia & 0 & 0 & $10 * *(2.1)$ & $10 * *(1.8)$ & $10 * *(2.0)$ & $6^{* *}(2.3)$ & $10^{\dagger \dagger}(2.8)$ \\
\hline $\begin{array}{l}\text { Inflammation, } \\
\text { Chronic Active }\end{array}$ & 0 & 0 & $10 * *(1.8)$ & $10 * *(1.7)$ & $10 * *(2.0)$ & $6^{* *}(2.0)$ & $10^{\dagger \dagger}(2.0)$ \\
\hline $\begin{array}{l}\text { Epidermis, Inflammation, } \\
\text { Suppurative }\end{array}$ & 0 & 0 & 0 & $1(1.0)$ & $4 *(1.3)$ & $4 * *(1.3)$ & $7^{\dagger \dagger}(1.3)$ \\
\hline Hair Follicle, Hyperplasia & 0 & 0 & $3(1.3)$ & 0 & $4 *(2.8)$ & $3 *(2.0)$ & $10^{\dagger \dagger}(2.0)$ \\
\hline $\begin{array}{l}\text { Skin Adjacent to the } \\
\text { Site of Application }\end{array}$ & 10 & 10 & 10 & 10 & 10 & 8 & 10 \\
\hline Fibrosis & 0 & 0 & 0 & $3(1.3)$ & 0 & 0 & $6^{\dagger \dagger}(1.5)$ \\
\hline Hyperkeratosis & 0 & 0 & 0 & $1(1.0)$ & 0 & 0 & $7^{\dagger \dagger}(2.0)$ \\
\hline
\end{tabular}


OTNE, NTP TOX 92

\begin{tabular}{|c|c|c|c|c|c|c|c|}
\hline & $\begin{array}{l}\text { Untreated } \\
\text { Control }\end{array}$ & $\begin{array}{l}\text { Vehicle } \\
\text { Control }\end{array}$ & $6.25 \%$ & $12.5 \%$ & $25 \%$ & $50 \%$ & $100 \%$ \\
\hline Hyperplasia & 0 & 0 & $4 *(1.0)$ & $3(1.7)$ & $2(1.0)$ & $3(1.0)$ & $10^{\dagger \dagger}(2.1)$ \\
\hline $\begin{array}{l}\text { Inflammation, } \\
\text { Chronic Active }\end{array}$ & 0 & 0 & $4 *(1.3)$ & $4 *(1.5)$ & $2(1.5)$ & $3(1.3)$ & $8^{\dagger \dagger}(1.9)$ \\
\hline $\begin{array}{l}\text { Epidermis, Inflammation, } \\
\text { Suppurative }\end{array}$ & 0 & 0 & 0 & 0 & 0 & 0 & $8^{\dagger \dagger}(1.6)$ \\
\hline Hair Follicle, Hyperplasia & 0 & 0 & 0 & 0 & $1(1.0)$ & 0 & $3(2.0)$ \\
\hline \multicolumn{8}{|c|}{$\begin{array}{l}\text { TSignificantly different }(\mathrm{P} \leq 0.05) \text { from the untreated control group by the Fisher exact test. } \\
\text { a } \leq \leq 0.01 \text {. }\end{array}$} \\
\hline
\end{tabular}

\section{Genetic Toxicology}

OTNE (Lot RAV0276433, the same lot used in the 3-month toxicity study with a concentration range of 100 to $10,000 \mu \mathrm{g} /$ plate) was not mutagenic in Salmonella typhimurium strains TA98, TA100, or TA102, with or without exogenous metabolic activation (Table E-1). A second sample of OTNE (Lot RAV0276433 with a concentration range of 100 to 6,000 $\mu \mathrm{g} / \mathrm{plate}$ ) was also shown to be nonmutagenic in S. typhimurium strains TA98 or TA100, as well as in Escherichia coli strain WP2 uvrA/pKM101, with and without S9 activation (Table E-2).

The effect of 3 months of dermal exposure to OTNE on micronucleus frequency and erythropoiesis in $\mathrm{F} 344 / \mathrm{NTac}$ rats and $\mathrm{B} 6 \mathrm{C} 3 \mathrm{~F} 1 / \mathrm{N}$ mice was examined in two experiments, a multidose experiment and a single-dose experiment. Four doses ranging from $6.25 \%$ to $50 \%$ OTNE were compared to a $95 \%$ ethanol vehicle control, whereas $100 \%$ (neat) OTNE was compared to an untreated control. No significant increases in micronucleated reticulocytes or erythrocytes were seen in male or female F344/NTac rats following exposure to OTNE, and no changes in the percentage of reticulocytes was observed in either sex of rat (Table E-3). In the multidose test in male rats, the mean frequency of micronucleated reticulocytes was significantly $(\mathrm{P}<0.025)$ elevated over the control in the two highest dose groups, but the magnitudes of the increases were very small, the trend test was not significant, and the response measured in the group that received 100\% OTNE was lower than either of these two values; therefore, the response in male rat reticulocytes in the multidose test was judged to be negative. In male mice, OTNE did not increase the frequency of micronucleated reticulocytes in the multi- or single-dose experiments (Table E-4). OTNE also did not increase the frequency of micronucleated mature erythrocytes in the multidose experiment. However, an increase in the frequency of micronucleated mature erythrocytes was detected in male mice exposed to 100\% OTNE. Although this increase was statistically significant $(\mathrm{P}=0.001)$, the magnitude of the increase was very small ( $1.45 \pm 0.02$ in the control versus $1.59 \pm 0.03$ in the treated group) and therefore, the result was judged to be equivocal. In female mice, OTNE did not increase the frequency of micronucleated reticulocytes in the multidose experiment. However, micronucleated reticulocytes were significantly increased $(\mathrm{P}=0.005)$ in female mice exposed to $100 \%$ OTNE. Furthermore, micronucleated mature erythrocytes were significantly increased in a dose- 
dependent manner $(\mathrm{P}<0.001)$ and also in the single-dose experiment $(\mathrm{P}<0.001)$. Therefore, the results of these tests in female mice were judged to be positive. The percentage of reticulocytes was significantly increased in female mice exposed to $100 \%$ OTNE $(1.08 \pm 0.15$ in the control versus $1.89 \pm 0.25$ in the treated group); however, the absolute percentage of reticulocytes in the $100 \%$ OTNE group was equal to or less than the percentages seen in the $12.5 \%$ to $50 \%$ OTNEtreated female mice, and other measures of reticulocyte numbers did not indicate that OTNE stimulated erythropoiesis. Considering all the data, the increase in the percentage of reticulocytes in the $100 \%$ OTNE group was not considered to be biologically significant.



Figure 4. Normal Epidermis (Arrows) in the Skin (Site of Application) of a Vehicle Control Female F344/NTac Rat in the Three Month Dermal Study of OTNE (H\&E)

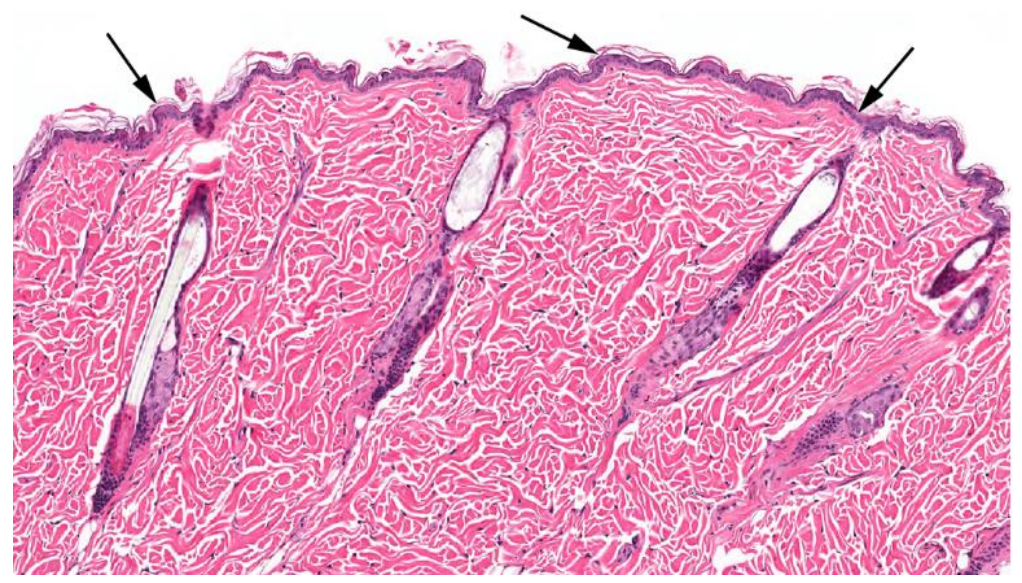

Figure 5. Higher Magnification of Figure 4 (H\&E)

Normal epidermis (arrows) consists of a single layer of squamous epithelium that is slightly keratinized. 


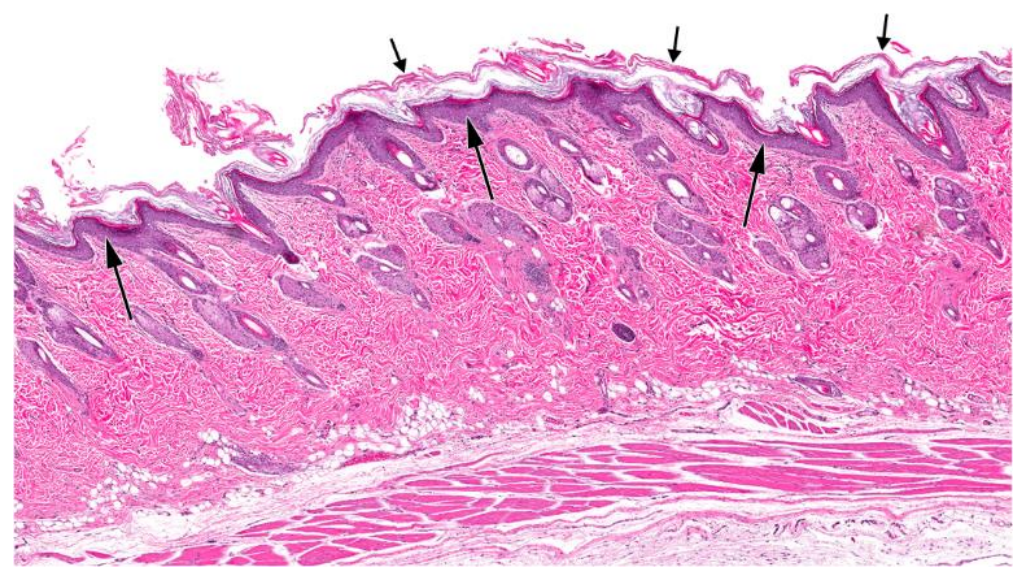

Figure 6. Mild Hyperplasia (Long Arrows) and Hyperkeratosis (Short Arrows) in the Skin (Site of Application) of a Female F344/NTac Rat Dermally Administered 100\% OTNE for Three Months (H\&E)

Compared to Figure 4, the epidermis and keratin layers appear thickened.

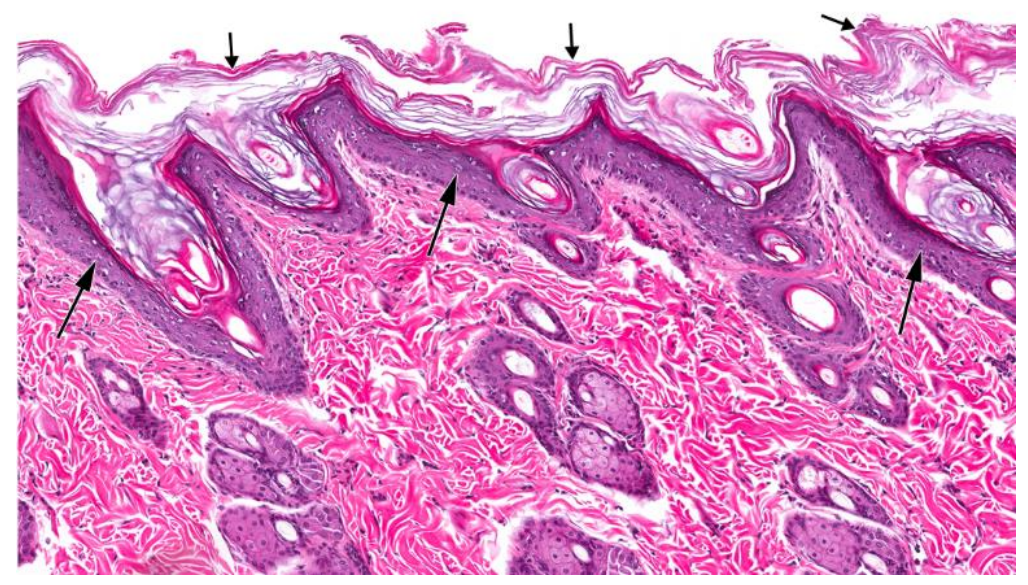

Figure 7. Higher Magnification of Figure $6(H \& E)$

Compared to Figure 5, the granular cell layer (stratum granulosum) of the epidermis is thickened (hyperplasia) due to an increased number of cell layers (long arrows). Epidermal hyperplasia is accompanied by hyperkeratosis (short arrows) that consists of mild thickening of the keratin layer (stratum corneum). 


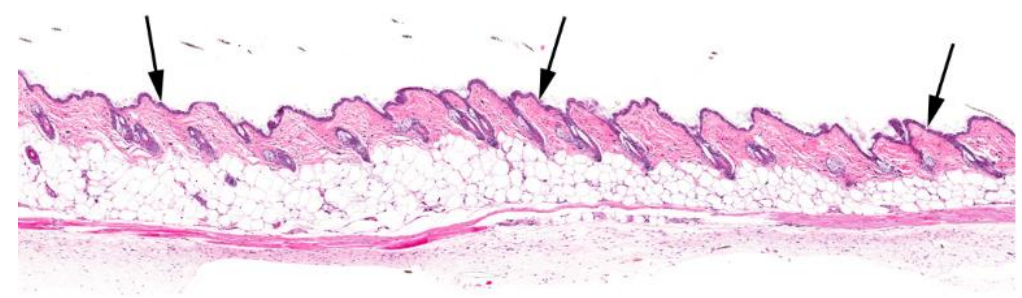

Figure 8. Normal Epidermis (Arrows) in the Skin (Site of Application) of a Vehicle Control Female B6C3F1/N Mouse in the Three-month Dermal Study of OTNE (H\&E)

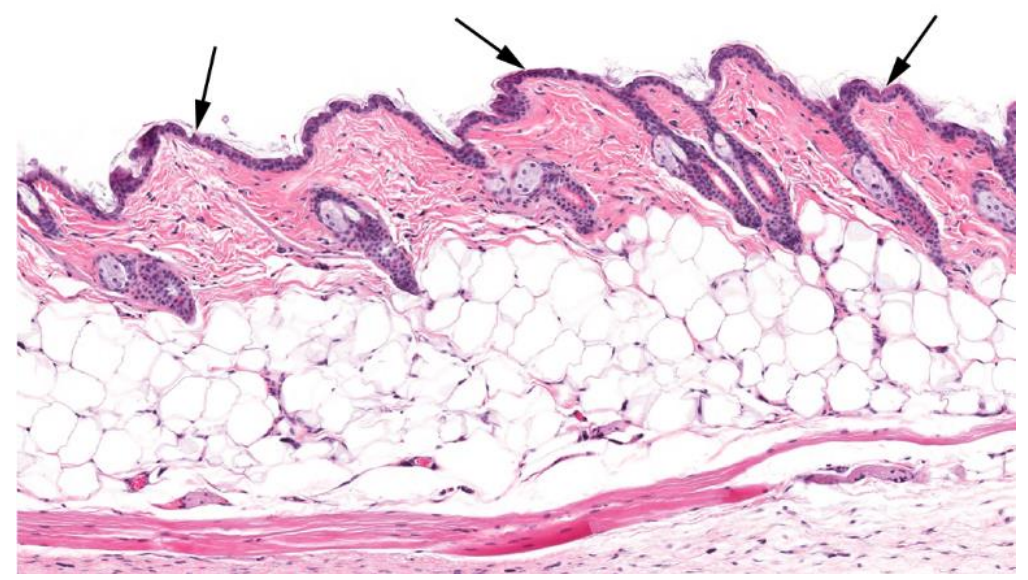

Figure 9. Higher Magnification of Figure $8(\mathrm{H} \& \mathrm{E})$

Normal epidermis (arrows) consists of squamous epithelium (one to two layers thick) that is slightly keratinized. 


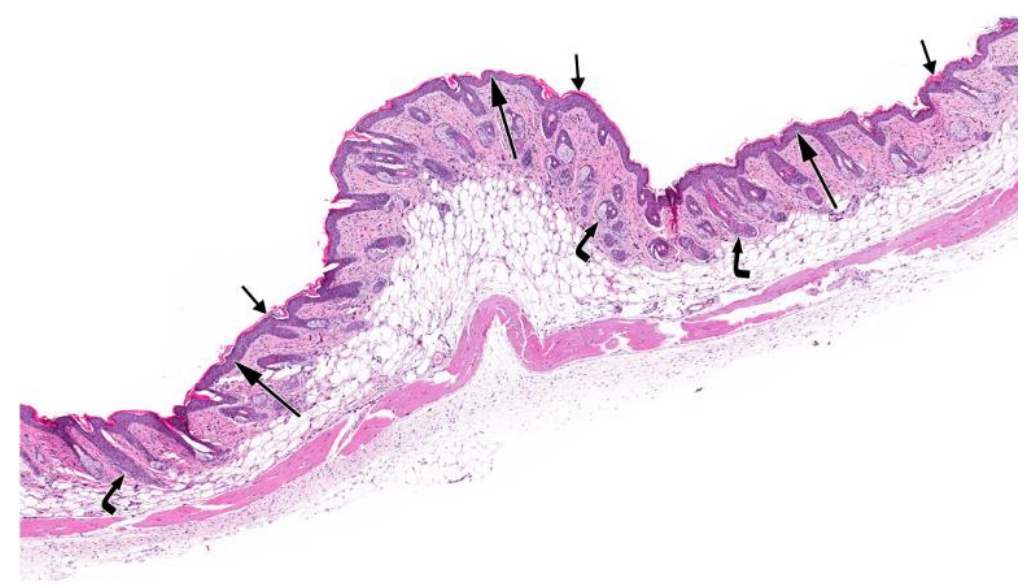

Figure 10. Moderate Hyperplasia (Long Arrows) and Mild Hyperkeratosis (Short Arrows) in the Skin (Site of Application) of a Female B6C3F1/N Mouse Dermally Administered 6.25\% OTNE for Three Months (H\&E)

Compared to Figure 8, the epidermis and keratin layers are thickened. There are increased numbers of hair follicle profiles (hair follicle hyperplasia) within the dermis (curved arrows).

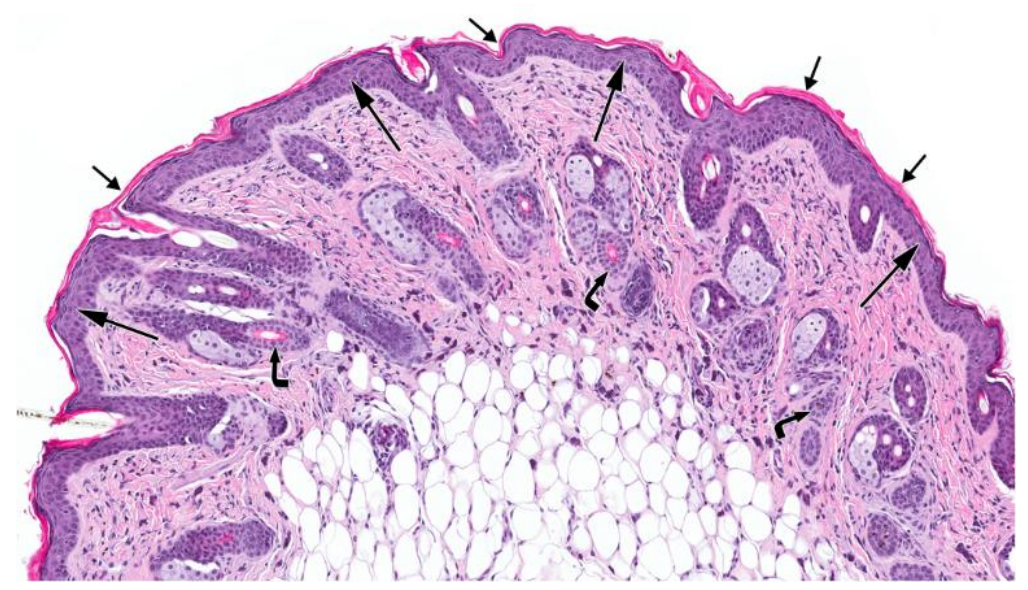

Figure 11. Higher Magnification of Figure $10(H \& E)$

Compared to Figure 9, there is moderate thickening of the epidermal stratum granulosum (long arrows) and mild hyperkeratotic thickening of the keratin layer (short arrows). Note increased numbers of hair follicle profiles (hair follicle hyperplasia) and thickening of the follicular epithelium that is similar to that in the epidermis. There are increased infiltrates of inflammatory cells (chronic active inflammation) within the dermis. Note also that there is hyperplasia and hypertrophy of the sebaceous glands associated with the hyperplastic hair follicles (curved arrows). 




\section{Figure 12. Suppurative Inflammation in the Skin (Site of Application) of a Female B6C3F1/N Mouse Dermally Administered 100\% OTNE for Three Months (H\&E)}

Suppurative inflammation (long arrows) consists of multifocal aggregates of neutrophils (pustules) within the stratum corneum. Compared to Figure 8, the dermis appears diffusely pale (short arrows) due to replacement of normally present dermal collagen fibers by connective tissue (fibrosis). Note also that there is epidermal hyperplasia and hyperkeratosis, and hair follicle hyperplasia.

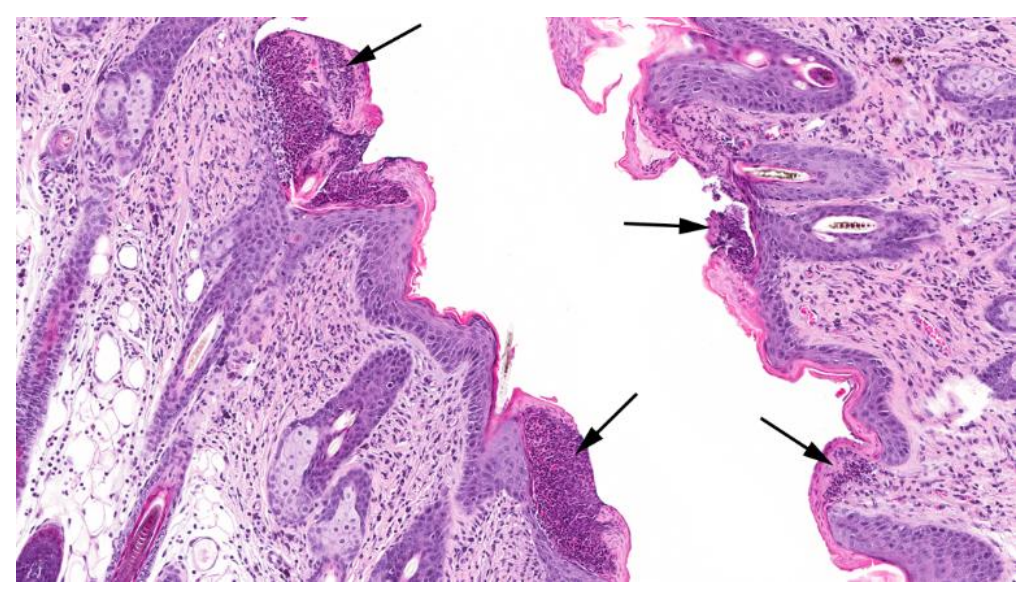

Figure 13. Higher Magnification of Figure $12(\mathrm{H} \& \mathrm{E})$

Note multifocal aggregates of neutrophils (suppurative inflammation) within the stratum corneum and connective tissue (fibrosis) within the dermis (arrows). Note also epidermal hyperplasia and hyperkeratosis, hair follicle hyperplasia, and infiltrates of mononuclear inflammatory cells and neutrophils (chronic active inflammation) in the dermis extending into the subcutis. 


\section{Discussion}

OTNE is classified as an unsaturated alkyl cyclic ketone fragrance ingredient commonly referred to by the commercial name Iso-E Super ${ }^{\circledR}$. Similar to other fragrance materials, OTNE is used as a perfume ingredient in soaps, shampoos, colognes, liquid detergent compounds, and malodorreducing compounds including fabric freshening compounds, antiperspirants or deodorants, and air freshening compounds. Exposure to OTNE by the general public is primarily through dermal absorption and inhalation from products that contain the ingredient. It is estimated that OTNE is typically less than $1 \%$ in individual consumer household products with the exception of fine fragrances that may have up to $20 \% \mathrm{OTNE}^{3 ; 4}$. The predicted human dermal exposure is calculated to be $0.4604 \mathrm{mg} / \mathrm{kg}$ body weight per day ${ }^{4}$.

OTNE toxicity data is summarized in REACH Dossiers in the European Chemicals Agency (ECHA) database and in a review by the Research Institute for Fragrance Materials ${ }^{4}$; however, the full reports of these toxicity studies are not publicly available. In these summaries, there is no mention of any subchronic or chronic toxicity studies of OTNE in rodents. The current Toxicity Study Report describes the 3-month toxicity studies of OTNE administered to F344/NTac rats and $\mathrm{B} 6 \mathrm{C} 3 \mathrm{~F} 1 / \mathrm{N}$ mice by dermal absorption which is the primary route of human exposure. OTNE is considered to have minimal acute toxicity in rats (dermal and oral $\mathrm{LD}_{50}>5 \mathrm{~g} / \mathrm{kg}$ ) ${ }^{4}$. For sufficient hazard characterization in these studies, neat OTNE (100\%) was applied dermally as the highest achievable concentration to rats and mice and corresponds to approximately $500 \mathrm{mg}$ OTNE/ $\mathrm{kg}$ body weight per day and $2,000 \mathrm{mg} / \mathrm{kg}$ per day, respectively. OTNE was dissolved in $95 \%$ aqueous ethanol to achieve lower concentrations of $6.25 \%, 12.5 \%, 25 \%$, and $50 \%$ OTNE. Because the $100 \%$ OTNE animals did not receive ethanol, two control groups were included in the study design. For the untreated controls, animals were handled similarly but did not receive any treatment at the site of application, whereas the vehicle control animals received $95 \%$ ethanol at the site of application. The untreated controls served as a comparison for the $100 \%$ OTNE group, and the vehicle controls were used for comparing data from the $6.25 \%$ to $50 \%$ OTNE groups. Statistical comparisons between control groups were conducted, and no biologically relevant differences were observed (data not shown) suggesting that dermal exposure of ethanol over this time did not interfere with our assessment of OTNE toxicity.

Results of the current 3-month studies demonstrated that the skin at the site of application was considered the primary target of OTNE toxicity across both sexes and species. Mortality was not observed in either sex or species. Small but significant decreases in body weights were observed in male mice. Organ weight changes (absolute and relative) were observed at the end of the studies; some of the organ weight changes were accompanied by histopathologic lesions.

The majority of nonneoplastic lesions following the 3-month dermal exposure of OTNE occurred in the skin at the site of application of rats and mice. In general, hyperplasia and hyperkeratosis were observed in both sexes and both species. However, the incidences and the severities of these lesions were greater in male and female mice than in rats. Incidences of minimal to mild hyperplasia and hyperkeratosis were significantly increased in rats administered $12.5 \%$ OTNE or greater, whereas minimal to moderate hyperplasia and hyperkeratosis were observed in nearly all dosed groups of male and female mice. Furthermore, hyperplasia and hyperkeratosis in mice were accompanied by increased incidences of minimal to mild chronic active inflammation, fibrosis, epidermis suppurative inflammation, and hair follicle hyperplasia. These lesions also 
extended to the skin adjacent to the site of application in male and female mice and were considered secondary to the spread of the test material from the site of application rather than the result of a systemic OTNE effect. One likely explanation for the species differences in skin lesion incidences and severities is the applied dose. On a $\mathrm{mg} / \mathrm{kg}$ body weight basis, as noted above, mice received doses of OTNE approximately four times higher than rats in this study. Another possibility is that mice on a C57BL/6 background have an increased susceptibility to idiopathic, spontaneous ulcerative dermatitis ${ }^{58}$, and this increased susceptibility may have made the mice more sensitive to the irritating effects of OTNE and consequently exacerbated the severity of the skin lesions.

The skin lesions observed in the current studies have not previously been reported in the OTNE literature. However, these skin lesions were consistent with reports from a 3-month dermal study with a similar fragrance chemical, acetyl cedrene. The study summary available in Belsito et al. ${ }^{1}$ highlights that dosed rats administered acetyl cedrene [0 (water), 50, 150, or $300 \mathrm{mg} / \mathrm{kg}$ body weight per day] had evidence of skin irritation, mild chronic inflammation, and hyperkeratosis. Although the full study report is not publicly available for a side-by-side comparison with the current subchronic dermal studies, this information suggests that long-term use of fragrance compounds with an alkyl cyclic ketone structure has the potential for chronic toxicity to the skin.

The skin lesions observed in the current studies in rats and mice after dermal exposure for 3 months are consistent with evidence from human and animal irritation and sensitization studies. Previously, NTP concluded that OTNE was an irritant and had the potential to induce skin sensitization in female BALB/c mice examined in a combined local lymph node (LLNA) and irritancy assay ${ }^{22}$. In this study, all mice treated with OTNE (0.5\% to 50\%) demonstrated significant irritation at the site of application. In the LLNA study, significant increases in lymph node cell proliferation were observed at concentrations of $25 \%$ and $50 \%$ only, suggesting that the positive response in this assay is a nonspecific response due to the irritant effect of the chemical. Variable results have been reported with regard to the ability of OTNE to act as a sensitizer and/or an irritant, as summarized in a review from the Research Institute for Fragrance Materials ${ }^{4}$ and also in the ECHA database. For example, OTNE was classified as a skin sensitizer in CBA/J mice following application of $2.5 \%$ to $50 \% \mathrm{OTNE}^{23-25}$. Conversely, in guinea pig and rabbit primary irritation studies, OTNE did not produce irritation in multiple acute tests at applied doses of less than $5 \%{ }^{4}$. In repeated application studies, $2.5 \%$ OTNE in ethanol caused skin irritation in guinea pigs ${ }^{1}$. While the majority of human repeated insult patch tests indicated that OTNE is not a skin irritant, irritancy was observed in human volunteers administered OTNE at concentrations greater than $12.5 \%$ in two cases ${ }^{1}$. It is difficult to determine the reason for the variable responses in these studies; however, it appears that both dose and frequency of exposure may play a role.

In male and female rats, treatment-related increases in absolute and relative liver weights were observed. Increases were significant in the 50\% and 100\% OTNE groups. This finding was consistent with a previous summary report demonstrating increased liver weights in rats administered 1,000 mg OTNE/kg body weight by gavage for 4 weeks ${ }^{21}$. In that same report, increased liver weights were associated with centrilobular hepatocyte enlargement. However, histologic changes were not observed in the livers of rats following dermal application of OTNE for 3 months in the current study. The lack of histologic findings in the rat liver may be due to the route of administration (oral versus dermal) as well as dose; the highest dose administered in the current study was approximately $500 \mathrm{mg} / \mathrm{kg}$. 
In the current studies, dose-related increases in the absolute and relative liver weights of male and female mice were also observed, and the increases (ranging from $62 \%$ to $92 \%$ above controls) were significant in males treated with $12.5 \%$ OTNE or greater and all dosed female groups. Unlike rats treated with OTNE, increased liver weights in dosed mice were accompanied by minimal induction of cytochrome P4502E1 (Cyp2e1) activities and an increased incidence of centrilobular hypertrophy in males administered 100\% OTNE. These species differences may be attributed to the fact that mice were treated with four times more OTNE on a $\mathrm{mg} / \mathrm{kg}$ per day basis. Although statistically significant, the magnitudes of the Cyp2el activity increases were less than twofold in both male and female mice and may have marginally contributed to the increased liver weights or the increased incidence of centrilobular hypertrophy. Collectively, increased liver weights accompanied by increased Cyp $2 e 1$ activities and mild histopathologic changes indicate that dermal exposure to OTNE has the potential to cause some systemic toxicity. Although OTNE was administered dermally in the current studies, some oral exposure was anticipated based on animal grooming ${ }^{17}$ and could have contributed to the observed systemic toxicity in the liver. In a review of industry studies with several alkyl cyclic ketone fragrance compounds, the liver has been a common target (increased organ weights and some evidence of minimal hepatocyte hypertrophy) in several animal studies where compounds were administered dermally or by the oral route ${ }^{1}$. These changes were reported to occur at high doses and were considered adaptive by the authors.

Other organ weight changes were observed in the current studies in the high dose groups (100\% OTNE) of rats and mice. In rats, a small but significant increase in relative kidney weights was observed in the $100 \%$ OTNE male and female dose groups. Kidney lesions were not observed by histopathology in this study. However, eosinophilic inclusions in kidney cortical tubules of male rats, treated for 4 weeks with 150 or $1,000 \mathrm{mg} / \mathrm{kg}$ OTNE by gavage, were reported elsewhere ${ }^{21}$. Likewise, the kidney has been reported as a target for toxicity in subacute and subchronic rat studies following exposure to various other alkyl cyclic ketone fragrance compounds ${ }^{1}$. In mice, $100 \%$ OTNE elicited small but significant decreases in male and female thymus weights, although histopathologic changes were not observed and the toxicologic relevance of these weight changes is not known.

OTNE exposure via dermal application exhibited the potential to be a reproductive toxicant in male and female B6C3F1/N mice, but not in F344/NTac rats, as evidenced by fewer sperm, lower sperm motility, and alterations in estrous cyclicity. Recent reviews summarizing the toxicology information on OTNE (and other similar fragrance compounds) have not reported any toxicologic effects in rat reproductive tissues. Toxicity studies in mice that have included these endpoints are limited ${ }^{1 ; 4}$. Nevertheless, the differential response observed between species reported here may be the result of mice receiving a higher dose compared to rats.

In studies performed by NTP, OTNE was not mutagenic in vitro. This finding is consistent with industry studies demonstrating that OTNE was negative in bacterial mutagenicity tests and in mouse lymphoma L5178Y tk+/- cells treated with OTNE ${ }^{33 ; 34}$. Additionally, many other structurally related, unsaturated ketone fragrances have been found to be nonmutagenic in vitro ${ }^{1}$. OTNE was considered negative for chromosomal aberrations when tested in human lymphocytes ${ }^{34}$. However, in the NTP 3-month in vivo studies, OTNE was equivocal in male mice and positive in female mice in the micronucleus assay, which detects clastogenic and aneugenic events. These findings were based on statistically significant increases in the frequency of micronucleated mature erythrocytes in 100\% OTNE male mice and, in female 
mice, dose-dependent increases in micronucleated mature erythrocytes and an increase in mature erythrocytes in a single-dose experiment with 100\% OTNE, all of which reached statistical significance. It should be noted, however, that the statistically significant effects detected in dosed male and female mice were very small increases compared to the vehicle controls or untreated controls, which calls into question their biological significance. OTNE was negative for the micronucleus assay in male and female F344/NTac rats. Overall, this is the first study to suggest that repeated dermal application of OTNE may have genotoxic effects.

Under the conditions of these 3-month dermal studies, the major target in F344/NTac rats and B6C3F1/N mice was the skin, site of application. Lesions were more prominent in mice than rats based upon the incidences and severities of hyperplasia, hyperkeratosis, and inflammation of the skin, site of application. Additionally, hepatic lesions were apparent in mice, but not rats. OTNE exhibited the potential to be a reproductive toxicant in male and female mice. These species differences could be attributed to dose, because mice received approximately four times the amount of OTNE on a $\mathrm{mg} / \mathrm{kg}$ body weight basis than rats. In male and female rats, the lowestobserved-effect level (LOEL) of 12.5\% OTNE was based on the increased incidences of skin lesions. In male and female mice, the LOEL was $6.25 \%$ OTNE, based on the increased incidences of skin lesions and increased relative liver weights. 


\section{OTNE, NTP TOX 92}

\section{References}

1. Belsito D, Bickers D, Bruze M, Calow P, Dagli M, Fryer A, Greim H, Miyachi Y, Saurat J, Sipes I. A toxicological and dermatological assessment of alkyl cyclic ketones when used as fragrance ingredients. Food Chem Toxicol. 2013; 62:S1-S44.

http://dx.doi.org/10.1016/j.fct.2013.09.033

2. Politano VT, Letizia CS, Christian MS, Diener RM, Api AM. Evaluation of the developmental toxicity of 1-(1,2,3,4,5,6,7,8-Octahydro-2,3,8,8-tetramethyl-2-naphthalenyl) ethanone (OTNE) in rats. Int J Toxicol. 2009; 28(3):213-218. http://dx.doi.org/10.1177/1091581809335862

3. Wishneff J. Letter from Director, Government Affairs and Counsel, of International Fragrance Association North America to Dr. Maria Doa, regarding the response to EPA's 2012 TSCA work plan chemicals: CASRN: 54464-57-2; 54464-59-4; 68155-66-8; 68155-67-9 dated August 31, 2012. http://www.regulations.gov/\#!documentDetail;D=EPA-HQ-OPPT-2011-0516-0020 (click on comment) [Accessed: September 11, 2013]

4. Scognamiglio J, Letizia C, Politano V, Api A. Fragrance material review on 1-(1,2,3,4,5,6,7,8octahydro-2,3,8,8-tetramethyl-2-naphthalenyl) ethanone (OTNE). Food Chem Toxicol. 2013; 62:S120-S132. http://dx.doi.org/10.1016/j.fct.2013.08.056

5. Fahlbusch K, Hammerschmidt F, Panten J, Pickenhagen W, Schatkowski D, Bauer K, Garbe D, Surburg H. Flavors and fragrances In: Ullmann's Encyclopedia of Industrial Chemistry, 7th ed, Sections 1.5.1-1.5.2. Wiley-VCH Verlag GmbH \& Co., KgaA; 2003. http://dx.doi.org/10.1002/14356007.a11_141

6. United States Environmental Protection Agency (USEPA). Non-confidential 2006 IUR records by chemical, including manufacturing, processing and use information. CAS: 54464-572. 2010. https://www.epa.gov/chemical-data-reporting/downloadable-2006-iur-public-database [Accessed: September 11, 2013]

7. United States Environmental Protection Agency (USEPA). Non-confidential 2006 IUR records by chemical, including manufacturing, processing and use information. CAS: 68155-679. 2010. https://www.epa.gov/chemical-data-reporting/downloadable-2006-iur-public-database [Accessed: September 11, 2013]

8. United States Environmental Protection Agency (USEPA). Non-confidential 2006 IUR records by chemical, including manufacturing, processing and use information. CAS: 68155-668. 2010. https://www.epa.gov/chemical-data-reporting/downloadable-2006-iur-public-database [Accessed: September 11, 2013]

9. Yin J, Wang H, Zhang J, Zhou N, Gao F, Wu Y, Xiang J, Shao B. The occurrence of synthetic musks in human breast milk in Sichuan, China. Chemosphere. 2012; 87(9):1018-1023. http://dx.doi.org/10.1016/j.chemosphere.2011.11.068

10. Kubwabo C, Fan X, Rasmussen PE, Wu F. Determination of synthetic musk compounds in indoor house dust by gas chromatography-ion trap mass spectrometry. Anal Bioanal Chem. 2012; 404(2):467-477. http://dx.doi.org/10.1007/s00216-012-6124-2 
OTNE, NTP TOX 92

11. Bester K, Klasmeier J, Kupper T. Emissions of OTNE (Iso-E-super)-Mass flows in sewage treatment plants. Chemosphere. 2008; 71(11):2003-2010.

http://dx.doi.org/10.1016/j.chemosphere.2008.02.004

12. Klaschka U, von der Ohe PC, Bschorer A, Krezmer S, Sengl M, Letzel M. Occurrences and potential risks of 16 fragrances in five German sewage treatment plants and their receiving waters. Environ Sci Pollut Res. 2013; 20(4):2456-2471. http://dx.doi.org/10.1007/s11356-012$\underline{1120-9}$

13. Simonich SL, Begley WM, Debaere G, Eckhoff WS. Trace analysis of fragrance materials in wastewater and treated wastewater. Environ Sci Technol. 2000; 34(6):959-965.

http://dx.doi.org/10.1021/es991018g

14. United States Environmental Protection Agency (USEPA). TSCA work plan for chemical assessments: 2012. Washington, DC: US Environmental Protection Agency, Office of Pollution Prevention and Toxics; 2012.

https://web.archive.org/web/20120316163830/http://www.epa.gov/oppt/existingchemicals/pubs/ Work_Plan_Chemicals_Web_Final.pdf [Accessed: March 11, 2015]

15. United States Environmental Protection Agency (USEPA). TSCA work plan for chemical assessments: 2014 update. Washington, DC: US Environmental Protection Agency, Office of Pollution Prevention and Toxics; 2014.

https://web.archive.org/web/20150419054002/http://www.epa.gov/oppt/existingchemicals/pubs/ TSCA_Work_Plan_Chemicals_2014_Update-final.pdf [Accessed: March 11, 2015]

16. European Chemicals Agency (ECHA). Registered substances database: REACH (Registration, Evaluation, Authorisation and Restriction of Chemicals): Reaction mass of 1 (1,2,3,4,5,6,7,8-octahydro-2,3,8,8-tetramethyl-2-naphthyl)ethan-1-one and 1-(1,2,3,4,6,7,8,8aoctahydro-2,3,8,8 tetramethyl-2-naphthyl) ethan-1-one and 1 (1,2,3,5,6,7,8,8a-octahydro-2,3,8,8tetramethyl-2-naphthyl)ethan-1-one: Exp key basic toxicokinetics.001. Study report, 2001-10-01. 2013. http://apps.echa.europa.eu/registered/data/dossiers/DISS-a001d05a-8c59-0cab-e04400144f67d031/AGGR-ad2f646c-2f3d-4148-bdd1-077723ea48d3 DISS-a001d05a-8c59-0cabe04400144f67d031.html\#AGGR-ad2f646c-2f3d-4148-bdd1-077723ea48d3 [Accessed:

September 12, 2013]

17. Waidyanatha S, Ryan K. Disposition of fragrance ingredient [14C] 1-(1,2,3,4,5,6,7,8octahydro-2,3,8,8-tetramethyl-2-naphthalenyl) ethanone in male Fisher rats following oral administration and dermal application. Xenobiotica. 2014; 44(8):749-756.

http://dx.doi.org/10.3109/00498254.2014.888489

18. European Chemicals Agency (ECHA). Registered substances database: REACH (Registration, Evaluation, Authorisation and Restriction of Chemicals): Reaction mass of 1(1,2,3,4,5,6,7,8-octahydro-2,3,8,8-tetramethyl-2-naphthyl)ethan-1-one and 1-(1,2,3,4,6,7,8,8aoctahydro-2,3,8,8-tetramethyl-2-naphthyl)ethan-1-one and 1 (1,2,3,5,6,7,8,8a-octahydro-2,3,8,8tetramethyl-2-naphthyl)ethan-1-one: Exp key dermal absorption.001. Study report, 2001-01-04. 2013. http://apps.echa.europa.eu/registered/data/dossiers/DISS-a001d05a-8c59-0cab-e04400144f67d031/AGGR-70883983-bb18-4318-a52d-f5fed32b1e10_DISS-a001d05a-8c59-0cabe044-00144f67d031.html\#AGGR-70883983-bb18-4318-a52d-f5fed32b1e10 [Accessed:

September 12, 2013] 
19. European Chemicals Agency (ECHA). Registered substances database: REACH (Registration, Evaluation, Authorisation and Restriction of Chemicals): Reaction mass of 1(1,2,3,4,5,6,7,8-octahydro-2,3,8,8-tetramethyl-2-naphthyl)ethan-1-one and 1-(1,2,3,4,6,7,8,8aoctahydro-2,3,8,8-tetramethyl-2-naphthyl)ethan-1-one and 1 (1,2,3,5,6,7,8,8a-octahydro-2,3,8,8tetramethyl-2-naphthyl)ethan-1-one: Exp key acute toxicity: oral.001. Study report, 1980-08-29. 2013. http://apps.echa.europa.eu/registered/data/dossiers/DISS-a001d05a-8c59-0cab-e04400144f67d031/AGGR-cbb53c2a-6567-4566-ac7c-120d3f7c8f63 DISS-a001d05a-8c59-0cabe044-00144f67d031.html\#AGGR-cbb53c2a-6567-4566-ac7c-120d3f7c8f63 [Accessed:

September 12, 2013]

20. European Chemicals Agency (ECHA). Registered substances database: REACH (Registration, Evaluation, Authorisation and Restriction of Chemicals): Reaction mass of 1(1,2,3,4,5,6,7,8-octahydro-2,3,8,8-tetramethyl-2-naphthyl)ethan-1-one and 1-(1,2,3,4,6,7,8,8aoctahydro-2,3,8,8-tetramethyl-2-naphthyl)ethan-1-one and 1 (1,2,3,5,6,7,8,8a-octahydro-2,3,8,8tetramethyl-2-naphthyl)ethan-1-one: Exp key acute toxicity: dermal.001. Study report, 1980-0829. 2013. http://apps.echa.europa.eu/registered/data/dossiers/DISS-a001d05a-8c59-0cab-e044 00144f67d031/AGGR-fd7ec48a-ec1d-4378-9fa0-87f99335e98f_DISS-a001d05a-8c59-0cabe0440144f67d031.html\#AGGR-fd7ec48a-ec1d-4378-9fa0-87f99335e98f [Accessed: September 12, 2013]

21. European Chemicals Agency (ECHA). Registered substances database: REACH (Registration, Evaluation, Authorisation and Restriction of Chemicals): Reaction mass of 1(1,2,3,4,5,6,7,8-octahydro-2,3,8,8-tetramethyl-2-naphthyl)ethan-1-one and 1-(1,2,3,4,6,7,8,8aoctahydro-2,3,8,8-tetramethyl-2-naphthyl)ethan-1-one and 1 (1,2,3,5,6,7,8,8a-octahydro-2,3,8,8tetramethyl-2-naphthyl)ethan-1-one: Exp key repeated dose toxicity: oral.001. Study report, 1997-10-12. 2013. http://apps.echa.europa.eu/registered/data/dossiers/DISS-a001d05a-8c590cab-e044-00144f67d031/AGGR-8c7e47a4-b969-4bd1-8606-02eb2f6d1f72_DISS-a001d05a8c59-0cab-e04400144f67d031.html\#AGGR-8c7e47a4-b969-4bd1-8606-02eb2f6d1f72 [Accessed: September 12, 2013]

22. National Toxicology Program (NTP). NTP report on the assessment of contact hypersensitivity to iso-E super in female BALB/c mice (CASRN: 54464-57-2). Research Triangle Park, NC: National Institute of Environmental Health Science; 2010. Report Number: IMM20702.

23. European Chemicals Agency (ECHA). Registered substances database: REACH (Registration, Evaluation, Authorisation and Restriction of Chemicals): Reaction mass of 1(1,2,3,4,5,6,7,8-octahydro-2,3,8,8-tetramethyl-2-naphthyl)ethan-1-one and 1-(1,2,3,4,6,7,8,8aoctahydro-2,3,8,8-tetramethyl-2-naphthyl)ethan-1-one and 1 (1,2,3,5,6,7,8,8a-octahydro-2,3,8,8tetramethyl-2-naphthyl)ethan-1-one: Exp key skin sensitisation.001. Study report, 2008-07-30. 2013. http://apps.echa.europa.eu/registered/data/dossiers/DISS-a001d05a-8c59-0cab-e04400144f67d031/AGGR-93d75f77-896b-43cb-9336-227c780478fb_DISS-a001d05a-8c59-0cabe044-00144f67d031.html\#AGGR-93d75f77-896b-43cb-9336-227c780478fb [Accessed:

September 12, 2013]

24. European Chemicals Agency (ECHA). Registered substances database: REACH (Registration, Evaluation, Authorisation and Restriction of Chemicals): Reaction mass of 1(1,2,3,4,5,6,7,8-octahydro-2,3,8,8-tetramethyl-2-naphthyl)ethan-1-one and 1-(1,2,3,4,6,7,8,8a- 


\section{OTNE, NTP TOX 92}

octahydro-2,3,8,8-tetramethyl-2-naphthyl)ethan-1-one and 1 (1,2,3,5,6,7,8,8a-octahydro-2,3,8,8tetramethyl-2-naphthyl)ethan-1-one: Exp NS skin sensitisation.003. Study report, 2008-07-30. 2013. http://apps.echa.europa.eu/registered/data/dossiers/DISS-a001d05a-8c59-0cab-e04400144f67d031/AGGR-ef39d1f0-064d-49c3-9e56-f9583df0b585_DISS-a001d05a-8c59-0cabe044-00144f67d031.html\#AGGR-ef39d1f0-064d-49c3-9e56-f9583df0b585 [Accessed:

September 12, 2013]

25. European Chemicals Agency (ECHA). Registered substances database: REACH (Registration, Evaluation, Authorisation and Restriction of Chemicals): Reaction mass of 1(1,2,3,4,5,6,7,8-octahydro-2,3,8,8-tetramethyl-2-naphthyl)ethan-1-one and 1-(1,2,3,4,6,7,8,8aoctahydro-2,3,8,8-tetramethyl-2-naphthyl)ethan-1-one and 1 (1,2,3,5,6,7,8,8a-octahydro-2,3,8,8tetramethyl-2-naphthyl)ethan-1-one: Exp NS skin sensitisation.004. Study report, 2005-11-09. 2013. http://apps.echa.europa.eu/registered/data/dossiers/DISS-a001d05a-8c59-0cab-e04400144f67d031/AGGR-413b6384-5dce-40a2-a590-c6f8a066cc43 DISS-a001d05a-8c59-0cabe044-00144f67d031.html\#AGGR-413b6384-5dce-40a2-a590-c6f8a066cc43 [Accessed: September 12, 2013]

26. Frosch P, Pilz B, Andersen KE, Burrows D, Camarasa J, Dooms-Goossens A, Ducombs G, Fuchs T, Hannusksela M, Lachapelle J et al. Patch testing with fragrances: Results of a multicenter study of the European Environmental and Contact Dermatitis Research Group with 48 frequently used constituents of perfumes. Contact Dermatitis. 1995; 33(5):333-342. http://dx.doi.org/10.1111/j.1600-0536.1995.tb02048.x

27. Frosch P, Johansen J, Menné T, Pirker C, Rastogi S, Andersen K, Bruze M, Goossens A, Lepoittevin J, White I. Further important sensitizers in patients sensitive to fragrances. Contact Dermatitis. 2002; 47(78-85).

28. Larsen W, Nakayama H, Fischer T, Elsner P, Frosch P, Burrows D, Jordan W, Shaw S, Wilkinson J, Marks J et al. Fragrance contact dermatitis: A worldwide multicenter investigation (Part II). Contact Dermatitis. 2001; 44(6):344-346. http://dx.doi.org/10.1034/j.1600$\underline{0536.2001 .044006344 . x}$

29. European Chemicals Agency (ECHA). Registered substances database: REACH (Registration, Evaluation, Authorisation and Restriction of Chemicals): Reaction mass of 1(1,2,3,4,5,6,7,8-octahydro-2,3,8,8-tetramethyl-2-naphthyl)ethan-1-one and 1-(1,2,3,4,6,7,8,8aoctahydro-2,3,8,8-tetramethyl-2-naphthyl)ethan-1-one and 1 (1,2,3,5,6,7,8,8a-octahydro-2,3,8,8tetramethyl-2-naphthyl)ethan-1-one: Exp NS skin irritation/corrosion.002. Study report, 200410-03. 2013. http://apps.echa.europa.eu/registered/data/dossiers/DISS-a001d05a-8c59-0cabe044-00144f67d031/AGGR-8053966f-162e-4bc6-8f4b-79b43a4cef90_DISS-a001d05a-8c590cab-e044-00144f67d031.html\#AGGR-8053966f-162e-4bc6-8f4b-79b43a4cef90 [Accessed: September 12, 2013]

30. European Chemicals Agency (ECHA). Registered substances database: REACH (Registration, Evaluation, Authorisation and Restriction of Chemicals): Reaction mass of 1(1,2,3,4,5,6,7,8-octahydro-2,3,8,8-tetramethyl-2-naphthyl)ethan-1-one and 1-(1,2,3,4,6,7,8,8aoctahydro-2,3,8,8-tetramethyl-2-naphthyl)ethan-1-one and 1 (1,2,3,5,6,7,8,8a-octahydro-2,3,8,8tetramethyl-2-naphthyl)ethan-1-one: Exp NS skin sensitisation.002.Study report, 2004-06-24. 2013. http://apps.echa.europa.eu/registered/data/dossiers/DISS-a001d05a-8c59-0cab-e04400144f67d031/AGGR-e895e29d-7a39-418d-a142-7f05e7f435fa_DISS-a001d05a-8c59-0cab- 
e044-00144f67d031.html\#AGGR-e895e29d-7a39-418d-a142-7f05e7f435fa [Accessed:

September 12, 2013]

31. European Chemicals Agency (ECHA). Registered substances database: REACH (Registration, Evaluation, Authorisation and Restriction of Chemicals): Reaction mass of 1(1,2,3,4,5,6,7,8-octahydro-2,3,8,8-tetramethyl-2-naphthyl)ethan-1-one and 1-(1,2,3,4,6,7,8,8aoctahydro-2,3,8,8-tetramethyl-2-naphthyl)ethan-1-one and 1 (1,2,3,5,6,7,8,8a-octahydro-2,3,8,8tetramethyl-2-naphthyl)ethan-1-one: Exp key skin irritation/corrosion.001. Study report, 201009-16. 2013. http://apps.echa.europa.eu/registered/data/dossiers/DISS-a001d05a-8c59-0cabe044-00144f67d031/AGGR-0c30a54f-3d41-4673-b1b7-4336690b0ea8_DISS-a001d05a-8c590cab-e044-00144f67d031.html\#AGGR-0c30a54f-3d41-4673-b1b7-4336690b0ea8 [Accessed: May 28, 2013]

32. European Chemicals Agency (ECHA). Registered substances database: REACH (Registration, Evaluation, Authorisation and Restriction of Chemicals): Reaction mass of 1(1,2,3,4,5,6,7,8-octahydro-2,3,8,8-tetramethyl-2-naphthyl)ethan-1-one and 1-(1,2,3,4,6,7,8,8aoctahydro-2,3,8,8-tetramethyl-2-naphthyl)ethan-1-one and 1 (1,2,3,5,6,7,8,8a-octahydro-2,3,8,8tetramethyl-2-naphthyl)ethan-1-one: Exp supporting toxicity to reproduction: other studies.001. Study report, 2002-11-20. 2013. http://apps.echa.europa.eu/registered/data/dossiers/DISSa001d05a-8c59-0cab-e044-00144f67d031/AGGR-57d3ac43-af43-49f9-9738ff58b21765c3_DISS-a001d05a-8c59-0cab-e044-00144f67d031.html\#AGGR-57d3ac43-af4349f9-9738-ff58b21765c3 [Accessed: September 12, 2013]

33. European Chemicals Agency (ECHA). Registered substances database: REACH (Registration, Evaluation, Authorisation and Restriction of Chemicals): Reaction mass of 1(1,2,3,4,5,6,7,8-octahydro-2,3,8,8-tetramethyl-2-naphthyl)ethan-1-one and 1-(1,2,3,4,6,7,8,8aoctahydro-2,3,8,8-tetramethyl-2-naphthyl)ethan-1-one and 1-(1,2,3,5,6,7,8,8a-octahydro-2,3,8,8tetramethyl-2-naphthyl)ethan-1-one: Exp key genetic toxicity in vitro.003. Study report, 199710-07. 2013. http://apps.echa.europa.eu/registered/data/dossiers/DISS-a001d05a-8c59-0cabe044-00144f67d031/AGGR-d71efec5-1810-4f2b-b765-48fa0c31e7e7_DISS-a001d05a-8c590cab-e044-00144f67d031.html\#AGGR-d71efec5-1810-4f2b-b765-48fa0c31e7e7 [Accessed: September 12, 2013]

34. European Chemicals Agency (ECHA). Registered substances database: REACH (Registration, Evaluation, Authorisation and Restriction of Chemicals): Reaction mass of 1(1,2,3,4,5,6,7,8-octahydro-2,3,8,8-tetramethyl-2-naphthyl)ethan-1-one and 1-(1,2,3,4,6,7,8,8aoctahydro-2,3,8,8-tetramethyl-2-naphthyl)ethan-1-one and 1 (1,2,3,5,6,7,8,8a-octahydro-2,3,8,8tetramethyl-2-naphthyl)ethan-1-one: Exp key genetic toxicity in vitro.001. Study report, 199708-11. 2013. http://apps.echa.europa.eu/registered/data/dossiers/DISS-a001d05a-8c59-0cabe044-00144f67d031/AGGR-7df5870e-c2d8-46d7-8d79-08c5db840c1c_DISS-a001d05a-8c590cab-e044-00144f67d031.html\#AGGR-7df5870e-c2d8-46d7-8d79-08c5db840c1c [Accessed: September 12, 2013]

35. European Chemicals Agency (ECHA). Registered substances database: REACH (Registration, Evaluation, Authorisation and Restriction of Chemicals): Reaction mass of 1(1,2,3,4,5,6,7,8-octahydro-2,3,8,8-tetramethyl-2-naphthyl)ethan-1-one and 1-(1,2,3,4,6,7,8,8aoctahydro-2,3,8,8-tetramethyl-2-naphthyl)ethan-1-one and 1 (1,2,3,5,6,7,8,8a-octahydro-2,3,8,8tetramethyl-2-naphthyl)ethan-1-one: Exp key genetic toxicity in vitro.002. Study report, 2010 
[date not provided]. 2013. http://apps.echa.europa.eu/registered/data/dossiers/DISS-a001d05a8c59-0cab-e044-00144f67d031/AGGR-eca5ba36-e259-4635-9223-c7d2b48cfaf7_DISSa001d05a-8c59-0cab-e044-00144f67d031.html\#AGGR-eca5ba36-e259-4635-9223c7d2b48cfaf7 [Accessed: September 12, 2013]

36. Erman M, Williams M, Whelan P, Cardenas C, Antipin M. The composition of Iso E Super. Perfum Flavor. 2001; 26(2):16-21.

37. King-Herbert A, Thayer K. NTP workshop: Animal models for the NTP rodent cancer bioassay: Stocks and strains_-should we switch? Toxicol Pathol. 2006; 34(6):802-805. http://dx.doi.org/10.1080/01926230600935938

38. Cederbaum AI. Role of CYP2E1 in ethanol-induced oxidant stress, fatty liver and hepatotoxicity. Dig Dis. 2010; 28(6):802-811. http://dx.doi.org/10.1159/000324289

39. Maronpot R, Boorman G. Interpretation of rodent hepatocellular proliferative alterations and hepatocellular tumors in chemical safety assessment. Toxicol Pathol. 1982; 10(2):71-78. http://dx.doi.org/10.1177/019262338201000210

40. Boorman GA, Montgomery CA, Jr., Eustis SL, Wolfe MJ, McConnell EE, Hardisty JF. Quality assurance in pathology for rodent carcinogenicity studies. In: Milman HA, Weisburger EK, editors. Handbook of Carcinogen Testing. Park Ridge, NJ: Noyes Publications; 1985. p. 345-357.

41. Gart JJ, Chu KC, Tarone RE. Statistical issues in interpretation of chronic bioassay tests for carcinogenicity. J Natl Cancer Inst. 1979; 62(4):957-974.

42. Dunnett CW. A multiple comparison procedure for comparing several treatments with a control. J Am Stat Assoc. 1955; 50(272):1096-1121. http://dx.doi.org/10.1080/01621459.1955.10501294

43. Williams D. The comparison of several dose levels with a zero dose control. Biometrics. 1972; 28(2):519-531. http://dx.doi.org/10.2307/2556164

44. Williams D. A test for differences between treatment means when several dose levels are compared with a zero dose control. Biometrics. 1971; 27(1):103-117.

http://dx.doi.org/10.2307/2528930

45. Shirley E. A non-parametric equivalent of Williams' test for contrasting increasing dose levels of a treatment. Biometrics. 1977; 33(2):386-389. http://dx.doi.org/10.2307/2529789

46. Williams D. A note on Shirley's nonparametric test for comparing several dose levels with a zero-dose control. Biometrics. 1986; 42(1):183-186. http://dx.doi.org/10.2307/2531254

47. Dunn OJ. Multiple comparisons using rank sums. Technometrics. 1964; 6(3):241-252. http://dx.doi.org/10.1080/00401706.1964.10490181

48. Jonckheere A. A distribution-free k-sample test against ordered alternatives. Biometrika. 1954; 41:133-145. http://dx.doi.org/10.1093/biomet/41.1-2.133 
OTNE, NTP TOX 92

49. Dixon W, Massey F. Introduction to statistical analysis. New York, NY: McGraw Hill Book Company Inc; 1957. http://dx.doi.org/10.2307/2332898

50. Girard D, Sager D. The use of Markov chains to detect subtle variation in reproductive cycling. Biometrics. 1987; 43(1):225-234. http://dx.doi.org/10.2307/2531963

51. Wilcoxon F. Individual comparisons by ranking methods. Biometrics Bull. 1945; 1(6):80-83. http://dx.doi.org/10.2307/3001968

52. Code of Federal Regulations (CFR). 21:Part 58.

53. Zeiger E, Anderson B, Haworth S, Lawlor T, Mortelmans K. Salmonella mutagenicity tests. V. Results from the testing of 311 chemicals. Environ Mol Mutagen. 1992; 19(S21):2-141. http://dx.doi.org/10.1002/em.2850190603

54. Dertinger SD, Camphausen K, MacGregor JT, Bishop ME, Torous DK, Avlasevich S, Cairns S, Tometsko CR, Menard C, Muanza T et al. Three-color labeling method for flow cytometric measurement of cytogenetic damage in rodent and human blood. Environ Mol Mutagen. 2004; 44(5):427-435. http://dx.doi.org/10.1002/em.20075

55. MacGregor JT, Bishop ME, McNamee JP, Hayashi M, Asano N, Wakata A, Nakajima M, Saito J, Aidoo A, Moore MM et al. Flow cytometric analysis of micronuclei in peripheral blood reticulocytes: II. An efficient method of monitoring chromosomal damage in the rat. Toxicol Sci. 2006; 94(1):92-107. http://dx.doi.org/10.1093/toxsci/kfl076

56. Witt KL, Livanos E, Kissling GE, Torous DK, Caspary W, Tice RR, Recio L. Comparison of flow cytometry-and microscopy-based methods for measuring micronucleated reticulocyte frequencies in rodents treated with nongenotoxic and genotoxic chemicals. Mutat Res. 2008; 649(1-2):101-113. http://dx.doi.org/10.1016/j.mrgentox.2007.08.004

57. Kissling GE, Dertinger SD, Hayashi M, MacGregor JT. Sensitivity of the erythrocyte micronucleus assay: Dependence on number of cells scored and inter-animal variability. Mutat Res. 2007; 634(1-2):235-240. http://dx.doi.org/10.1016/j.mrgentox.2007.07.010

58. Hampton AL, Hish GA, Aslam MN, Rothman ED, Bergin IL, Patterson KA, Naik M, Paruchuri T, Varani J, Rush HG. Progression of ulcerative dermatitis lesions in C57BL/6Crl mice and the development of a scoring system for dermatitis lesions. J Am Assoc Lab Anim Sci. 2012; 51(5):586-593. 


\section{Appendix A. Summary of Lesions in Rats and Mice}

\section{Tables}

Table A-1. Summary of the Incidence of Nonneoplastic Lesions in Male Rats in the Three-month Dermal Study of OTNE

Table A-2. Summary of the Incidence of Nonneoplastic Lesions in Female Rats in the Three-month Dermal Study of OTNE.

Table A-3. Summary of the Incidence of Neoplasms and Nonneoplastic Lesions in Male Mice in the Three-month Dermal Study of OTNE.

Table A-4. Summary of the Incidence of Nonneoplastic Lesions in Female Mice in the Three-month Dermal Study of OTNE 
OTNE, NTP TOX 92

Table A-1. Summary of the Incidence of Nonneoplastic Lesions in Male Rats in the Three-month Dermal Study of OTNE

\begin{tabular}{|c|c|c|c|c|c|c|c|}
\hline & $\begin{array}{c}\text { Untreated } \\
\text { Control }\end{array}$ & $\begin{array}{l}\text { Vehicle } \\
\text { Control }\end{array}$ & $6.25 \%$ & $12.5 \%$ & $25 \%$ & $\mathbf{5 0 \%}$ & $100 \%$ \\
\hline \multicolumn{8}{|l|}{ Disposition Summary } \\
\hline Animals initially in study & 10 & 10 & 10 & 10 & 10 & 10 & 10 \\
\hline \multicolumn{8}{|l|}{ Survivors } \\
\hline Terminal euthanasia & 10 & 10 & 10 & 10 & 10 & 10 & 10 \\
\hline $\begin{array}{l}\text { Animals examined } \\
\text { microscopically }\end{array}$ & 10 & 10 & 10 & 10 & 10 & 10 & 10 \\
\hline \multicolumn{8}{|l|}{ Alimentary System } \\
\hline Esophagus & (10) & (10) & (0) & (0) & $(0)$ & (0) & $(10)$ \\
\hline Intestine large, cecum & $(10)$ & (10) & (0) & $(0)$ & $(0)$ & $(0)$ & (10) \\
\hline Intestine large, colon & $(10)$ & (10) & (0) & $(0)$ & $(0)$ & $(0)$ & (10) \\
\hline Intestine large, rectum & (10) & (10) & (0) & (0) & (0) & (0) & (10) \\
\hline Intestine small, duodenum & (10) & (10) & (0) & $(0)$ & $(0)$ & (0) & (10) \\
\hline Intestine small, ileum & $(10)$ & (10) & (0) & $(0)$ & $(0)$ & (0) & (10) \\
\hline Intestine small, jejunum & (10) & (10) & (0) & (0) & $(0)$ & $(0)$ & $(10)$ \\
\hline Liver & $(10)$ & (10) & (10) & $(10)$ & $(10)$ & $(10)$ & (10) \\
\hline Inflammation, chronic & $1(10 \%)$ & - & - & - & - & - & - \\
\hline Oral mucosa & (10) & (10) & (0) & (0) & $(0)$ & (0) & (10) \\
\hline Pancreas & (10) & $(10)$ & (0) & (0) & (0) & (0) & $(10)$ \\
\hline Acinus, atrophy & - & $1(10 \%)$ & - & - & - & - & - \\
\hline Salivary glands & (10) & (10) & (0) & (0) & (0) & (0) & (10) \\
\hline Stomach, forestomach & (10) & (10) & (0) & (0) & (0) & (0) & (10) \\
\hline Stomach, glandular & (10) & (10) & (0) & (0) & $(0)$ & (0) & (10) \\
\hline Tongue & $(10)$ & (10) & $(0)$ & $(0)$ & $(0)$ & $(0)$ & (10) \\
\hline \multicolumn{8}{|l|}{ Cardiovascular System } \\
\hline Blood vessel & $(10)$ & (10) & (0) & (0) & $(0)$ & (0) & (9) \\
\hline Heart & (10) & (10) & (0) & (0) & (0) & (0) & (10) \\
\hline Cardiomyopathy & $1(10 \%)$ & $1(10 \%)$ & - & - & - & - & $1(10 \%)$ \\
\hline $\begin{array}{l}\text { Infiltration cellular, } \\
\text { histiocyte, focal }\end{array}$ & - & - & - & - & - & - & $1(10 \%)$ \\
\hline Inflammation, chronic & $1(10 \%)$ & - & - & - & - & - & - \\
\hline \multicolumn{8}{|l|}{ Endocrine System } \\
\hline Adrenal cortex & (10) & (10) & (0) & (0) & $(0)$ & $(0)$ & (10) \\
\hline Adrenal medulla & (10) & (10) & (0) & (0) & $(0)$ & (0) & (10) \\
\hline Parathyroid gland & (10) & (10) & (0) & $(0)$ & (0) & (0) & (10) \\
\hline
\end{tabular}


OTNE, NTP TOX 92

\begin{tabular}{|c|c|c|c|c|c|c|c|}
\hline & $\begin{array}{l}\text { Untreated } \\
\text { Control }\end{array}$ & $\begin{array}{l}\text { Vehicle } \\
\text { Control }\end{array}$ & $6.25 \%$ & $12.5 \%$ & $25 \%$ & $50 \%$ & $100 \%$ \\
\hline Pituitary gland & (9) & (8) & (0) & $(0)$ & $(0)$ & (0) & (9) \\
\hline Thyroid gland & $(10)$ & (10) & (0) & (0) & $(0)$ & (0) & (10) \\
\hline \multicolumn{8}{|l|}{ General Body System } \\
\hline None & - & - & - & - & - & - & - \\
\hline \multicolumn{8}{|l|}{ Genital System } \\
\hline Epididymis & $(10)$ & (10) & (0) & $(0)$ & $(0)$ & $(0)$ & (10) \\
\hline Preputial gland & (9) & (8) & (0) & $(0)$ & $(0)$ & (0) & (9) \\
\hline Inflammation, chronic & $2(22 \%)$ & - & - & - & - & - & $1(11 \%)$ \\
\hline Prostate & $(10)$ & (10) & (0) & $(0)$ & $(0)$ & (0) & (10) \\
\hline Seminal vesicle & (10) & (10) & (0) & $(0)$ & $(0)$ & (0) & (10) \\
\hline Testes & $(10)$ & (10) & $(0)$ & (0) & $(0)$ & $(0)$ & (10) \\
\hline \multicolumn{8}{|l|}{ Hematopoietic System } \\
\hline Bone marrow & $(10)$ & (10) & (0) & $(0)$ & $(0)$ & (0) & (10) \\
\hline Lymph node & $(0)$ & (0) & (0) & $(0)$ & $(0)$ & $(0)$ & (1) \\
\hline $\begin{array}{l}\text { Mediastinal, hyperplasia, } \\
\text { lymphoid, diffuse }\end{array}$ & - & - & - & - & - & - & $1(100 \%)$ \\
\hline Lymph node, mandibular & $(10)$ & (10) & (0) & $(0)$ & $(0)$ & $(0)$ & (10) \\
\hline Lymph node, mesenteric & $(10)$ & (10) & (0) & $(0)$ & $(0)$ & (0) & (10) \\
\hline $\begin{array}{l}\text { Infiltration cellular, } \\
\text { histiocyte }\end{array}$ & $1(10 \%)$ & $1(10 \%)$ & - & - & - & - & - \\
\hline Spleen & $(10)$ & (10) & (0) & $(0)$ & $(0)$ & $(0)$ & (10) \\
\hline Thymus & (10) & (10) & (0) & $(0)$ & $(0)$ & (0) & (10) \\
\hline \multicolumn{8}{|l|}{ Integumentary System } \\
\hline Mammary gland & $(10)$ & (10) & $(0)$ & (0) & $(0)$ & $(0)$ & (10) \\
\hline Skin & (10) & (10) & (10) & $(10)$ & (10) & (10) & (10) \\
\hline Hyperplasia & - & - & $1(10 \%)$ & - & - & - & - \\
\hline Inflammation & - & - & $1(10 \%)$ & - & - & - & - \\
\hline Skin, site of application & (10) & (10) & $(10)$ & (10) & (10) & (10) & (10) \\
\hline Hyperkeratosis & - & - & $1(10 \%)$ & $3(30 \%)$ & $4(40 \%)$ & $5(50 \%)$ & $8(80 \%)$ \\
\hline Hyperplasia & - & - & $2(20 \%)$ & $4(40 \%)$ & $5(50 \%)$ & $8(80 \%)$ & $10(100 \%)$ \\
\hline Inflammation & - & - & - & - & - & - & $1(10 \%)$ \\
\hline \multicolumn{8}{|l|}{ Musculoskeletal System } \\
\hline Bone & $(10)$ & (10) & (0) & $(0)$ & $(0)$ & (0) & (10) \\
\hline \multicolumn{8}{|l|}{ Nervous System } \\
\hline Brain & $(10)$ & (10) & $(0)$ & $(0)$ & $(0)$ & $(0)$ & (10) \\
\hline
\end{tabular}


OTNE, NTP TOX 92

\begin{tabular}{|c|c|c|c|c|c|c|c|}
\hline & $\begin{array}{l}\text { Untreated } \\
\text { Control }\end{array}$ & $\begin{array}{l}\text { Vehicle } \\
\text { Control }\end{array}$ & $6.25 \%$ & $12.5 \%$ & $25 \%$ & $50 \%$ & $100 \%$ \\
\hline \multicolumn{8}{|l|}{ Respiratory System } \\
\hline Larynx & $(10)$ & (10) & (0) & $(0)$ & (0) & (0) & (10) \\
\hline Inflammation, neutrophil & $1(10 \%)$ & - & - & - & - & - & - \\
\hline Lung & $(10)$ & (10) & (0) & $(0)$ & (0) & (0) & (10) \\
\hline Hemorrhage & $1(10 \%)$ & - & - & - & - & - & - \\
\hline $\begin{array}{l}\text { Infiltration cellular, } \\
\text { histiocyte }\end{array}$ & - & - & - & - & - & - & $1(10 \%)$ \\
\hline Inflammation, chronic & $4(40 \%)$ & $5(50 \%)$ & - & - & - & - & $5(50 \%)$ \\
\hline $\begin{array}{l}\text { Interstitium, inflammation, } \\
\text { focal }\end{array}$ & $2(20 \%)$ & $1(10 \%)$ & - & - & - & - & - \\
\hline Nose & $(10)$ & (10) & (0) & $(0)$ & $(0)$ & $(0)$ & (10) \\
\hline Trachea & (10) & $(10)$ & $(0)$ & $(0)$ & $(0)$ & $(0)$ & $(10)$ \\
\hline \multicolumn{8}{|l|}{ Special Senses System } \\
\hline Eye & (10) & (10) & (0) & (0) & (0) & (0) & (10) \\
\hline Harderian gland & (10) & (10) & $(0)$ & $(0)$ & $(0)$ & $(0)$ & (10) \\
\hline \multicolumn{8}{|l|}{ Urinary System } \\
\hline Kidney & (10) & (10) & (10) & (10) & (10) & (10) & (10) \\
\hline Nephropathy & $10(100 \%)$ & $8(80 \%)$ & $9(90 \%)$ & $10(100 \%)$ & $10(100 \%)$ & $10(100 \%)$ & $10(100 \%)$ \\
\hline Renal tubule, casts & $3(30 \%)$ & - & $1(10 \%)$ & $1(10 \%)$ & - & $1(10 \%)$ & - \\
\hline Urinary bladder & (10) & (10) & (0) & $(0)$ & $(0)$ & (0) & (10) \\
\hline
\end{tabular}

${ }^{a}$ Number of animals examined microscopically at the site and the number of animals with lesion. 
OTNE, NTP TOX 92

Table A-2. Summary of the Incidence of Nonneoplastic Lesions in Female Rats in the Three-month Dermal Study of OTNE

\begin{tabular}{|c|c|c|c|c|c|c|c|}
\hline & $\begin{array}{c}\text { Untreated } \\
\text { Control }\end{array}$ & $\begin{array}{l}\text { Vehicle } \\
\text { Control }\end{array}$ & $6.25 \%$ & $12.5 \%$ & $25 \%$ & $50 \%$ & $100 \%$ \\
\hline \multicolumn{8}{|l|}{ Disposition Summary } \\
\hline Animals initially in study & 10 & 10 & 10 & 10 & 10 & 10 & 10 \\
\hline \multicolumn{8}{|l|}{ Survivors } \\
\hline Terminal euthanasia & 10 & 10 & 10 & 10 & 10 & 10 & 10 \\
\hline $\begin{array}{l}\text { Animals examined } \\
\text { microscopically }\end{array}$ & 10 & 10 & 10 & 10 & 10 & 10 & 10 \\
\hline \multicolumn{8}{|l|}{ Alimentary System } \\
\hline Esophagus & (10) & (10) & (0) & (0) & $(0)$ & (0) & $(10)$ \\
\hline Intestine large, cecum & $(10)$ & (10) & (0) & $(0)$ & $(0)$ & (0) & (10) \\
\hline Intestine large, colon & $(10)$ & (10) & (0) & $(0)$ & $(0)$ & (0) & (10) \\
\hline Intestine large, rectum & (10) & (10) & (0) & (0) & $(0)$ & (0) & (10) \\
\hline Intestine small, duodenum & (10) & (10) & (0) & $(0)$ & $(0)$ & (0) & (10) \\
\hline Intestine small, ileum & $(10)$ & (10) & (0) & $(0)$ & $(0)$ & (0) & (10) \\
\hline Intestine small, jejunum & (10) & (10) & (0) & (0) & $(0)$ & (0) & $(10)$ \\
\hline Liver & $(10)$ & (10) & $(10)$ & $(10)$ & (10) & $(10)$ & (10) \\
\hline Inflammation, chronic & $6(60 \%)$ & $5(50 \%)$ & $7(70 \%)$ & $9(90 \%)$ & $5(50 \%)$ & $5(50 \%)$ & $5(50 \%)$ \\
\hline Oral mucosa & (10) & (10) & (0) & (0) & $(0)$ & (0) & (10) \\
\hline Pancreas & (10) & (10) & (0) & (0) & (0) & (0) & (10) \\
\hline Salivary glands & (10) & (10) & (0) & (0) & $(0)$ & (0) & (10) \\
\hline Stomach, forestomach & (10) & (10) & (0) & $(0)$ & $(0)$ & (0) & (10) \\
\hline Stomach, glandular & $(10)$ & (10) & (0) & $(0)$ & $(0)$ & (0) & (10) \\
\hline Tongue & $(10)$ & $(10)$ & $(0)$ & $(0)$ & $(0)$ & $(0)$ & (10) \\
\hline \multicolumn{8}{|l|}{ Cardiovascular System } \\
\hline Blood vessel & (9) & (10) & (0) & $(0)$ & $(0)$ & (0) & (10) \\
\hline Heart & (10) & (10) & (0) & (0) & $(0)$ & (0) & (10) \\
\hline Cardiomyopathy & - & $1(10 \%)$ & - & - & - & - & - \\
\hline \multicolumn{8}{|l|}{ Endocrine System } \\
\hline Adrenal cortex & (10) & (10) & (0) & (0) & (0) & (0) & (10) \\
\hline Adrenal medulla & (10) & (10) & (0) & (0) & $(0)$ & (0) & (10) \\
\hline Parathyroid gland & (9) & (10) & (0) & (0) & (0) & (0) & (10) \\
\hline Pituitary gland & (7) & (4) & (0) & (0) & $(0)$ & (0) & $(10)$ \\
\hline $\begin{array}{l}\text { Pars distalis, cyst, } \\
\text { multiple, focal }\end{array}$ & $1(14 \%)$ & - & - & - & - & - & - \\
\hline Thyroid gland & (10) & (10) & (0) & (0) & $(0)$ & (0) & (10) \\
\hline
\end{tabular}


OTNE, NTP TOX 92

\begin{tabular}{|c|c|c|c|c|c|c|c|}
\hline & $\begin{array}{l}\text { Untreated } \\
\text { Control }\end{array}$ & $\begin{array}{l}\text { Vehicle } \\
\text { Control }\end{array}$ & $6.25 \%$ & $12.5 \%$ & $25 \%$ & $50 \%$ & $100 \%$ \\
\hline \multicolumn{8}{|l|}{ General Body System } \\
\hline None & - & - & - & - & - & - & - \\
\hline \multicolumn{8}{|l|}{ Genital System } \\
\hline Clitoral gland & (9) & $(10)$ & (0) & $(0)$ & $(0)$ & (0) & (10) \\
\hline Inflammation, chronic & - & $1(10 \%)$ & - & - & - & - & - \\
\hline Ovary & (10) & (10) & (0) & $(0)$ & $(0)$ & (0) & (10) \\
\hline Uterus & (10) & (10) & (0) & $(0)$ & $(0)$ & (0) & (10) \\
\hline \multicolumn{8}{|l|}{ Hematopoietic System } \\
\hline Bone marrow & (10) & (10) & (0) & (0) & $(0)$ & (0) & (10) \\
\hline Lymph node & (0) & (1) & (0) & (0) & $(0)$ & (0) & (0) \\
\hline Iliac, hyperplasia, diffuse & - & $1(100 \%)$ & - & - & - & - & - \\
\hline Lymph node, mandibular & (10) & $(10)$ & (0) & (0) & $(0)$ & (0) & (10) \\
\hline Lymph node, mesenteric & (9) & (10) & (0) & (0) & $(0)$ & (0) & (10) \\
\hline $\begin{array}{l}\text { Infiltration cellular, } \\
\text { histiocyte }\end{array}$ & $4(44 \%)$ & $6(60 \%)$ & - & - & - & - & $5(50 \%)$ \\
\hline Spleen & (10) & (10) & (0) & (0) & $(0)$ & (0) & (10) \\
\hline Thymus & $(10)$ & (10) & $(0)$ & $(0)$ & $(0)$ & $(0)$ & (10) \\
\hline \multicolumn{8}{|l|}{ Integumentary System } \\
\hline Mammary gland & (8) & (10) & $(0)$ & (0) & $(0)$ & $(0)$ & (10) \\
\hline Skin & (10) & (10) & (10) & (10) & $(10)$ & (10) & (10) \\
\hline Skin, site of application & (10) & $(10)$ & $(10)$ & (10) & (10) & $(10)$ & (10) \\
\hline Hyperkeratosis & - & - & - & $4(40 \%)$ & $5(50 \%)$ & $7(70 \%)$ & $7(70 \%)$ \\
\hline Hyperplasia & - & - & $1(10 \%)$ & $5(50 \%)$ & $7(70 \%)$ & $7(70 \%)$ & $8(80 \%)$ \\
\hline $\begin{array}{l}\text { Dermis, inflammation, } \\
\text { suppurative }\end{array}$ & - & - & - & - & - & - & $1(10 \%)$ \\
\hline Hair follicle, necrosis & - & - & - & - & - & - & $1(10 \%)$ \\
\hline \multicolumn{8}{|l|}{ Musculoskeletal System } \\
\hline Bone & $(10)$ & (10) & (0) & $(0)$ & $(0)$ & $(0)$ & (10) \\
\hline \multicolumn{8}{|l|}{ Nervous System } \\
\hline Brain & (10) & (10) & (0) & (0) & (0) & (0) & (10) \\
\hline \multicolumn{8}{|l|}{ Respiratory System } \\
\hline Larynx & (10) & (10) & $(0)$ & (0) & $(0)$ & (0) & (10) \\
\hline Lung & (10) & (10) & $(0)$ & (0) & (0) & $(0)$ & (10) \\
\hline $\begin{array}{l}\text { Infiltration cellular, } \\
\text { histiocyte }\end{array}$ & - & - & - & - & - & - & $1(10 \%)$ \\
\hline Inflammation, chronic & $2(20 \%)$ & $3(30 \%)$ & - & - & - & - & $1(10 \%)$ \\
\hline
\end{tabular}


OTNE, NTP TOX 92

\begin{tabular}{|c|c|c|c|c|c|c|c|}
\hline & $\begin{array}{c}\text { Untreated } \\
\text { Control }\end{array}$ & $\begin{array}{l}\text { Vehicle } \\
\text { Control }\end{array}$ & $6.25 \%$ & $12.5 \%$ & $25 \%$ & $50 \%$ & $100 \%$ \\
\hline Mineralization & - & $1(10 \%)$ & - & - & - & - & - \\
\hline $\begin{array}{l}\text { Interstitium, inflammation, } \\
\text { focal }\end{array}$ & $3(30 \%)$ & $1(10 \%)$ & - & - & - & - & $1(10 \%)$ \\
\hline Nose & (10) & (10) & (0) & (0) & (0) & (0) & (10) \\
\hline Trachea & $(10)$ & (10) & (0) & (0) & (0) & (0) & (10) \\
\hline \multicolumn{8}{|l|}{ Special Senses System } \\
\hline Ear & (1) & (0) & (0) & (0) & (0) & (0) & (1) \\
\hline Eye & (10) & (10) & (0) & (0) & (0) & (0) & (10) \\
\hline Harderian gland & (10) & (10) & (0) & (0) & (0) & (0) & (10) \\
\hline Inflammation, chronic & $3(30 \%)$ & $1(10 \%)$ & - & - & - & - & $3(30 \%)$ \\
\hline \multicolumn{8}{|l|}{ Urinary System } \\
\hline Kidney & (10) & (10) & (10) & (10) & $(10)$ & (10) & (10) \\
\hline Inflammation, chronic & - & $2(20 \%)$ & - & - & $1(10 \%)$ & - & - \\
\hline Mineralization & - & $1(10 \%)$ & - & - & $2(20 \%)$ & - & $1(10 \%)$ \\
\hline Nephropathy & $2(20 \%)$ & $1(10 \%)$ & - & - & - & - & - \\
\hline $\begin{array}{l}\text { Pelvis, inflammation, } \\
\text { chronic }\end{array}$ & - & - & - & - & - & $1(10 \%)$ & - \\
\hline Urinary bladder & (9) & (9) & (0) & (0) & $(0)$ & (0) & (10) \\
\hline
\end{tabular}


OTNE, NTP TOX 92

Table A-3. Summary of the Incidence of Neoplasms and Nonneoplastic Lesions in Male Mice in the Three-month Dermal Study of OTNE ${ }^{a}$

\begin{tabular}{|c|c|c|c|c|c|c|c|}
\hline & $\begin{array}{c}\text { Untreated } \\
\text { Control }\end{array}$ & $\begin{array}{l}\text { Vehicle } \\
\text { Control }\end{array}$ & $6.25 \%$ & $12.5 \%$ & $25 \%$ & $50 \%$ & $100 \%$ \\
\hline \multicolumn{8}{|l|}{ Disposition Summary } \\
\hline Animals initially in study & 10 & 10 & 10 & 10 & 10 & 10 & 10 \\
\hline \multicolumn{8}{|l|}{ Survivors } \\
\hline Terminal euthanasia & 10 & 10 & 10 & 10 & 10 & 10 & 10 \\
\hline $\begin{array}{l}\text { Animals examined } \\
\text { microscopically }\end{array}$ & 10 & 10 & 10 & 10 & 10 & 10 & 10 \\
\hline \multicolumn{8}{|l|}{ Alimentary System } \\
\hline Esophagus & (9) & (10) & (0) & (0) & $(0)$ & $(0)$ & (9) \\
\hline Gallbladder & $(10)$ & (10) & (0) & (0) & $(0)$ & $(0)$ & (10) \\
\hline Intestine large, cecum & (10) & (10) & (0) & (0) & $(0)$ & $(0)$ & (10) \\
\hline Intestine large, colon & (10) & (10) & (0) & (0) & $(0)$ & (0) & $(10)$ \\
\hline Intestine large, rectum & $(10)$ & (10) & (0) & (0) & $(0)$ & (0) & $(10)$ \\
\hline Intestine small, duodenum & $(10)$ & (10) & (0) & (0) & $(0)$ & (0) & (10) \\
\hline Intestine small, ileum & (10) & (10) & $(0)$ & (0) & $(0)$ & $(0)$ & (10) \\
\hline Intestine small, jejunum & $(10)$ & (10) & $(0)$ & (0) & $(0)$ & (0) & $(10)$ \\
\hline Liver & $(10)$ & (10) & $(10)$ & $(10)$ & (9) & $(10)$ & $(10)$ \\
\hline Centrilobular, hypertrophy & - & $1(10 \%)$ & - & $2(20 \%)$ & $3(33 \%)$ & - & $4(40 \%)$ \\
\hline Oral mucosa & $(10)$ & (10) & (0) & (0) & $(0)$ & $(0)$ & $(10)$ \\
\hline Pancreas & (10) & (10) & (0) & (0) & $(0)$ & (0) & (10) \\
\hline Salivary glands & (10) & (10) & (0) & (0) & $(0)$ & (0) & (10) \\
\hline Stomach, forestomach & (10) & (10) & (0) & (0) & $(0)$ & (0) & (10) \\
\hline Stomach, glandular & (10) & (10) & (0) & (0) & $(0)$ & $(0)$ & (10) \\
\hline Tongue & $(10)$ & (10) & $(0)$ & $(0)$ & $(0)$ & $(0)$ & (10) \\
\hline \multicolumn{8}{|l|}{ Cardiovascular System } \\
\hline Blood vessel & (10) & (10) & (0) & (0) & $(0)$ & (0) & (10) \\
\hline Heart & $(10)$ & $(10)$ & $(0)$ & $(0)$ & $(0)$ & (0) & (10) \\
\hline \multicolumn{8}{|l|}{ Endocrine System } \\
\hline Adrenal cortex & $(10)$ & (10) & (0) & (0) & $(0)$ & $(0)$ & (10) \\
\hline Adrenal medulla & $(10)$ & (10) & (0) & (0) & $(0)$ & $(0)$ & $(10)$ \\
\hline Parathyroid gland & (9) & (10) & $(0)$ & $(0)$ & $(0)$ & $(0)$ & (10) \\
\hline Cyst & $1(11 \%)$ & $2(20 \%)$ & - & - & - & - & - \\
\hline Pituitary gland & (10) & (9) & (0) & (0) & $(0)$ & (0) & (10) \\
\hline Thyroid gland & $(10)$ & (10) & $(0)$ & (0) & $(0)$ & $(0)$ & $(10)$ \\
\hline Follicle, degeneration & $1(10 \%)$ & - & - & - & - & - & - \\
\hline
\end{tabular}


OTNE, NTP TOX 92

\begin{tabular}{|c|c|c|c|c|c|c|c|}
\hline & $\begin{array}{l}\text { Untreated } \\
\text { Control }\end{array}$ & $\begin{array}{l}\text { Vehicle } \\
\text { Control }\end{array}$ & $6.25 \%$ & $12.5 \%$ & $25 \%$ & $50 \%$ & $100 \%$ \\
\hline \multicolumn{8}{|l|}{ General Body System } \\
\hline None & - & - & - & - & - & - & - \\
\hline \multicolumn{8}{|l|}{ Genital System } \\
\hline Epididymis & $(10)$ & (10) & (0) & $(0)$ & $(0)$ & (0) & (10) \\
\hline Preputial gland & $(10)$ & (10) & (0) & (0) & $(0)$ & (0) & $(10)$ \\
\hline Prostate gland & $(10)$ & (10) & $(0)$ & $(0)$ & $(0)$ & (0) & (10) \\
\hline Seminal vesicle & $(10)$ & (10) & (0) & (0) & $(0)$ & (0) & (10) \\
\hline Testes & $(10)$ & (10) & (0) & $(0)$ & $(0)$ & (0) & $(10)$ \\
\hline \multicolumn{8}{|l|}{ Hematopoietic System } \\
\hline Bone marrow & (10) & (10) & (10) & (10) & (10) & (10) & (10) \\
\hline Lymph node, mandibular & (9) & (10) & $(0)$ & $(0)$ & $(0)$ & $(0)$ & (9) \\
\hline Lymph node, mesenteric & $(10)$ & (10) & $(0)$ & (0) & $(0)$ & $(0)$ & (10) \\
\hline Spleen & (10) & (10) & (10) & (10) & (9) & (10) & (10) \\
\hline Thymus & $(10)$ & (10) & $(0)$ & $(0)$ & $(0)$ & $(0)$ & (10) \\
\hline \multicolumn{8}{|l|}{ Integumentary System } \\
\hline Mammary gland & (4) & (4) & (0) & $(0)$ & $(0)$ & (0) & (4) \\
\hline Skin & (10) & (10) & (10) & (10) & (9) & (10) & (10) \\
\hline Fibrosis & - & - & - & - & $1(11 \%)$ & $2(20 \%)$ & $5(50 \%)$ \\
\hline Hyperkeratosis & - & - & - & - & - & $2(20 \%)$ & $5(50 \%)$ \\
\hline Hyperplasia & - & - & - & $2(20 \%)$ & $4(44 \%)$ & $3(30 \%)$ & $8(80 \%)$ \\
\hline Inflammation, neutrophil & - & - & - & - & - & - & $1(10 \%)$ \\
\hline $\begin{array}{l}\text { Inflammation, } \\
\text { chronic active }\end{array}$ & - & - & - & $2(20 \%)$ & $4(44 \%)$ & $2(20 \%)$ & $8(80 \%)$ \\
\hline $\begin{array}{l}\text { Epidermis, inflammation, } \\
\text { suppurative }\end{array}$ & - & - & - & - & - & $1(10 \%)$ & $4(40 \%)$ \\
\hline Hair follicle, hyperplasia & - & - & - & $1(10 \%)$ & - & $1(10 \%)$ & $5(50 \%)$ \\
\hline Skin, site of application & $(10)$ & $(10)$ & $(10)$ & $(10)$ & (10) & (9) & (10) \\
\hline Fibrosis & - & - & $4(40 \%)$ & $3(30 \%)$ & $8(80 \%)$ & $8(89 \%)$ & $10(100 \%)$ \\
\hline Hyperkeratosis & - & - & $2(20 \%)$ & $5(50 \%)$ & $5(50 \%)$ & $8(89 \%)$ & $10(100 \%)$ \\
\hline Hyperplasia & - & - & $9(90 \%)$ & $10(100 \%)$ & $9(90 \%)$ & $9(100 \%)$ & $10(100 \%)$ \\
\hline $\begin{array}{l}\text { Inflammation, } \\
\text { chronic active }\end{array}$ & - & - & $7(70 \%)$ & $10(100 \%)$ & $9(90 \%)$ & $9(100 \%)$ & $10(100 \%)$ \\
\hline $\begin{array}{l}\text { Epidermis, inflammation, } \\
\text { suppurative }\end{array}$ & - & - & - & - & $1(10 \%)$ & $1(11 \%)$ & $5(50 \%)$ \\
\hline Hair follicle, hyperplasia & - & - & $3(30 \%)$ & $2(20 \%)$ & $3(30 \%)$ & $7(78 \%)$ & $8(80 \%)$ \\
\hline
\end{tabular}


OTNE, NTP TOX 92

\begin{tabular}{|c|c|c|c|c|c|c|c|}
\hline & $\begin{array}{l}\text { Untreated } \\
\text { Control }\end{array}$ & $\begin{array}{l}\text { Vehicle } \\
\text { Control }\end{array}$ & $6.25 \%$ & $12.5 \%$ & $25 \%$ & $50 \%$ & $100 \%$ \\
\hline \multicolumn{8}{|l|}{ Musculoskeletal System } \\
\hline Bone & $(10)$ & (10) & (0) & (0) & (0) & $(0)$ & (10) \\
\hline Skeletal muscle & (0) & (1) & (0) & (0) & (0) & (0) & (0) \\
\hline \multicolumn{8}{|l|}{ Nervous System } \\
\hline Brain & (10) & (10) & (0) & (0) & (0) & $(0)$ & (10) \\
\hline $\begin{array}{l}\text { Granular cell tumor } \\
\text { malignant }\end{array}$ & - & $1(10 \%)$ & - & - & - & - & - \\
\hline \multicolumn{8}{|l|}{ Respiratory System } \\
\hline Larynx & (10) & (10) & (0) & (0) & (0) & (0) & (10) \\
\hline Lung & (10) & (10) & (0) & (0) & (0) & $(0)$ & (10) \\
\hline Nose & (10) & (10) & (0) & (0) & (0) & $(0)$ & (10) \\
\hline Trachea & (10) & (10) & (0) & $(0)$ & $(0)$ & $(0)$ & (10) \\
\hline \multicolumn{8}{|l|}{ Special Senses System } \\
\hline Eye & (10) & (10) & (0) & $(0)$ & (0) & $(0)$ & (10) \\
\hline Retina, dysplasia & - & $1(10 \%)$ & - & - & - & - & - \\
\hline $\begin{array}{l}\text { Retrobulbar, } \\
\text { inflammation, neutrophil }\end{array}$ & $1(10 \%)$ & - & - & - & - & - & - \\
\hline Harderian gland & (10) & (10) & (0) & (0) & (0) & $(0)$ & (10) \\
\hline Inflammation, neutrophil & - & $2(20 \%)$ & - & - & - & - & $1(10 \%)$ \\
\hline Inflammation, chronic & - & - & - & - & - & - & $1(10 \%)$ \\
\hline \multicolumn{8}{|l|}{ Urinary System } \\
\hline Kidney & (10) & (10) & (0) & $(0)$ & (0) & $(0)$ & (10) \\
\hline Inflammation, chronic & - & $1(10 \%)$ & - & - & - & - & - \\
\hline Urinary bladder & (10) & (10) & (0) & (0) & (0) & $(0)$ & (10) \\
\hline \multicolumn{8}{|l|}{ Neoplasm Summary } \\
\hline \multicolumn{2}{|c|}{ Animals with primary neoplasms ${ }^{\mathrm{b}}$} & 1 & - & - & - & - & - \\
\hline \multicolumn{2}{|l|}{ Total primary neoplasms } & 1 & - & - & - & - & - \\
\hline \multicolumn{2}{|c|}{ Total animals with malignant neoplasms } & 1 & - & - & - & - & - \\
\hline \multicolumn{2}{|l|}{ Total malignant neoplasms } & 1 & - & - & - & - & - \\
\hline
\end{tabular}

${ }^{a}$ Number of animals examined microscopically at the site and the number of animals with lesion.

bPrimary neoplasms: all neoplasms except metastatic neoplasms. 
OTNE, NTP TOX 92

Table A-4. Summary of the Incidence of Nonneoplastic Lesions in Female Mice in the Three-month Dermal Study of OTNE

\begin{tabular}{|c|c|c|c|c|c|c|c|}
\hline & $\begin{array}{l}\text { Untreated } \\
\text { Control }\end{array}$ & $\begin{array}{l}\text { Vehicle } \\
\text { Control }\end{array}$ & $6.25 \%$ & $12.5 \%$ & $25 \%$ & $50 \%$ & $100 \%$ \\
\hline \multicolumn{8}{|l|}{ Disposition Summary } \\
\hline Animals initially in study & 10 & 10 & 10 & 10 & 10 & 10 & 10 \\
\hline \multicolumn{8}{|l|}{ Survivors } \\
\hline Terminal euthanasia & 10 & 10 & 10 & 10 & 10 & 10 & 10 \\
\hline $\begin{array}{l}\text { Animals examined } \\
\text { microscopically }\end{array}$ & 10 & 10 & 10 & 10 & 10 & 10 & 10 \\
\hline \multicolumn{8}{|l|}{ Alimentary System } \\
\hline Esophagus & $(10)$ & (10) & (0) & $(0)$ & $(0)$ & $(0)$ & $(10)$ \\
\hline Gallbladder & $(10)$ & (9) & (0) & $(0)$ & $(0)$ & $(0)$ & (10) \\
\hline Intestine large, cecum & $(10)$ & (10) & (0) & (0) & $(0)$ & $(0)$ & (10) \\
\hline Intestine large, colon & (10) & (10) & (0) & $(0)$ & $(0)$ & $(0)$ & (10) \\
\hline Intestine large, rectum & $(10)$ & (10) & (0) & $(0)$ & $(0)$ & $(0)$ & (10) \\
\hline Intestine small, duodenum & $(10)$ & (10) & (0) & $(0)$ & (0) & $(0)$ & (10) \\
\hline Intestine small, ileum & (10) & (10) & (0) & $(0)$ & $(0)$ & $(0)$ & (10) \\
\hline Intestine small, jejunum & (10) & (10) & $(0)$ & $(0)$ & $(0)$ & (0) & (10) \\
\hline Liver & $(10)$ & (10) & (10) & $(10)$ & $(10)$ & (10) & (10) \\
\hline Oral mucosa & $(10)$ & (10) & (0) & $(0)$ & $(0)$ & $(0)$ & (10) \\
\hline Pancreas & (10) & (10) & (0) & $(0)$ & (0) & $(0)$ & (10) \\
\hline Salivary glands & (10) & (10) & (0) & (0) & $(0)$ & (0) & (10) \\
\hline Stomach, forestomach & $(10)$ & (10) & (0) & (0) & $(0)$ & $(0)$ & (10) \\
\hline Stomach, glandular & $(10)$ & (10) & (0) & $(0)$ & (0) & $(0)$ & (10) \\
\hline Tongue & $(10)$ & $(10)$ & $(0)$ & $(0)$ & (0) & $(0)$ & (10) \\
\hline \multicolumn{8}{|l|}{ Cardiovascular System } \\
\hline Blood vessel & (10) & (10) & (0) & $(0)$ & (0) & $(0)$ & (10) \\
\hline Heart & $(10)$ & (10) & (10) & $(10)$ & $(10)$ & (9) & (10) \\
\hline \multicolumn{8}{|l|}{ Endocrine System } \\
\hline Adrenal cortex & $(10)$ & (10) & (0) & $(0)$ & $(0)$ & (0) & $(10)$ \\
\hline Adrenal medulla & $(10)$ & (10) & (0) & (0) & $(0)$ & (0) & (10) \\
\hline Parathyroid gland & (9) & (7) & (0) & (0) & $(0)$ & (0) & (8) \\
\hline Cyst & - & - & - & - & - & - & $1(13 \%)$ \\
\hline Pituitary gland & (10) & (10) & (0) & $(0)$ & $(0)$ & $(0)$ & (9) \\
\hline Thyroid gland & $(10)$ & $(10)$ & $(0)$ & $(0)$ & $(0)$ & $(0)$ & $(10)$ \\
\hline \multicolumn{8}{|l|}{ General Body System } \\
\hline None & - & - & - & - & - & - & - \\
\hline
\end{tabular}


OTNE, NTP TOX 92

\begin{tabular}{|c|c|c|c|c|c|c|c|}
\hline & $\begin{array}{l}\text { Untreated } \\
\text { Control }\end{array}$ & $\begin{array}{l}\text { Vehicle } \\
\text { Control }\end{array}$ & $6.25 \%$ & $12.5 \%$ & $25 \%$ & $50 \%$ & $100 \%$ \\
\hline \multicolumn{8}{|l|}{ Genital System } \\
\hline Clitoral gland & (9) & (6) & (0) & $(0)$ & (0) & (0) & (10) \\
\hline Ovary & $(10)$ & (10) & (0) & (0) & (0) & (0) & (10) \\
\hline Uterus & $(10)$ & (10) & (0) & $(0)$ & (0) & (0) & (10) \\
\hline Vagina & (10) & (10) & $(0)$ & $(0)$ & $(0)$ & $(0)$ & (10) \\
\hline \multicolumn{8}{|l|}{ Hematopoietic System } \\
\hline Bone marrow & $(10)$ & (10) & $(10)$ & $(10)$ & $(10)$ & (10) & (10) \\
\hline Lymph node & (0) & (0) & (0) & (0) & (0) & (0) & (1) \\
\hline Lymph node, mandibular & (10) & (10) & (0) & $(0)$ & (0) & (0) & $(10)$ \\
\hline Lymph node, mesenteric & (10) & (10) & (0) & $(0)$ & (0) & (0) & (10) \\
\hline Spleen & (10) & (10) & $(10)$ & (10) & $(10)$ & (8) & (10) \\
\hline Thymus & (10) & (10) & $(10)$ & (10) & $(10)$ & (8) & (10) \\
\hline Atrophy & - & - & - & - & - & - & $2(20 \%)$ \\
\hline \multicolumn{8}{|l|}{ Integumentary System } \\
\hline Mammary gland & (10) & (10) & (0) & (0) & (0) & (0) & (10) \\
\hline Skin & $(10)$ & (10) & $(10)$ & (10) & $(10)$ & (8) & (10) \\
\hline Fibrosis & - & - & - & $3(30 \%)$ & - & - & $6(60 \%)$ \\
\hline Hyperkeratosis & - & - & - & $1(10 \%)$ & - & - & $7(70 \%)$ \\
\hline Hyperplasia & - & - & $4(40 \%)$ & $3(30 \%)$ & $2(20 \%)$ & $3(38 \%)$ & $10(100 \%)$ \\
\hline $\begin{array}{l}\text { Inflammation, } \\
\text { chronic active }\end{array}$ & - & - & $4(40 \%)$ & $4(40 \%)$ & $2(20 \%)$ & $3(38 \%)$ & $8(80 \%)$ \\
\hline Ulcer & - & - & - & - & - & - & $1(10 \%)$ \\
\hline $\begin{array}{l}\text { Epidermis, inflammation, } \\
\text { suppurative }\end{array}$ & - & - & - & - & - & - & $8(80 \%)$ \\
\hline Hair follicle, hyperplasia & - & - & - & - & $1(10 \%)$ & - & $3(30 \%)$ \\
\hline Skin, site of application & (10) & (10) & (10) & $(10)$ & (10) & (6) & (10) \\
\hline Fibrosis & - & - & $2(20 \%)$ & $10(100 \%)$ & $10(100 \%)$ & $4(67 \%)$ & $9(90 \%)$ \\
\hline Hyperkeratosis & - & - & $5(50 \%)$ & $5(50 \%)$ & $10(100 \%)$ & $6(100 \%)$ & $10(100 \%)$ \\
\hline Hyperplasia & - & - & $10(100 \%)$ & $10(100 \%)$ & $10(100 \%)$ & $6(100 \%)$ & $10(100 \%)$ \\
\hline $\begin{array}{l}\text { Inflammation, } \\
\text { chronic active }\end{array}$ & - & - & $10(100 \%)$ & $10(100 \%)$ & $10(100 \%)$ & $6(100 \%)$ & $10(100 \%)$ \\
\hline Ulcer & - & $1(10 \%)$ & - & - & - & $1(17 \%)$ & - \\
\hline $\begin{array}{l}\text { Epidermis, inflammation, } \\
\text { suppurative }\end{array}$ & - & - & - & $1(10 \%)$ & $4(40 \%)$ & $4(67 \%)$ & $7(70 \%)$ \\
\hline Hair follicle, hyperplasia & - & - & $3(30 \%)$ & - & $4(40 \%)$ & $3(50 \%)$ & $10(100 \%)$ \\
\hline
\end{tabular}


OTNE, NTP TOX 92

\begin{tabular}{|c|c|c|c|c|c|c|c|}
\hline & $\begin{array}{l}\text { Untreated } \\
\text { Control }\end{array}$ & $\begin{array}{l}\text { Vehicle } \\
\text { Control }\end{array}$ & $6.25 \%$ & $12.5 \%$ & $25 \%$ & $\mathbf{5 0 \%}$ & $100 \%$ \\
\hline \multicolumn{8}{|l|}{ Musculoskeletal System } \\
\hline Bone & (10) & (10) & (0) & (0) & (0) & (0) & (10) \\
\hline \multicolumn{8}{|l|}{ Nervous System } \\
\hline Brain & (10) & (10) & (0) & $(0)$ & $(0)$ & $(0)$ & (10) \\
\hline \multicolumn{8}{|l|}{ Respiratory System } \\
\hline Larynx & (10) & (10) & (0) & (0) & (0) & (0) & (10) \\
\hline Lung & (10) & (10) & (0) & $(0)$ & $(0)$ & (0) & (10) \\
\hline Nose & (10) & (10) & (0) & (0) & (0) & (0) & (10) \\
\hline Trachea & $(10)$ & (10) & (0) & (0) & $(0)$ & (0) & (10) \\
\hline \multicolumn{8}{|l|}{ Special Senses System } \\
\hline Eye & (10) & (10) & (0) & (0) & (0) & (0) & (10) \\
\hline $\begin{array}{l}\text { Retrobulbar, } \\
\text { inflammation, neutrophil }\end{array}$ & - & - & - & - & - & - & $1(10 \%)$ \\
\hline Harderian gland & (10) & (10) & (0) & $(0)$ & (0) & (0) & (10) \\
\hline \multicolumn{8}{|l|}{ Urinary System } \\
\hline Kidney & (10) & (10) & (0) & (0) & $(0)$ & (0) & (10) \\
\hline Nephropathy & - & $1(10 \%)$ & - & - & - & - & - \\
\hline Urinary bladder & (9) & (10) & (0) & (0) & (0) & (0) & (10) \\
\hline
\end{tabular}


OTNE, NTP TOX 92

\section{Appendix B. Clinical Pathology and Liver Toxicity Results}

\section{Tables}

Table B-1. Hematology and Clinical Chemistry Data for Rats in the Three-month Dermal Study of OTNE

Table B-2. Protein Yield and CYP2E1 Activity in the Liver of Rats in the Three-month Dermal Study of OTNE

Table B-3. Hematology Data for Mice in the Three-month Dermal Study of OTNE.....

Table B-4. CYP2E1 Activity in the Liver of Mice in the Three-month Dermal Study of OTNE 
OTNE, NTP TOX 92

Table B-1. Hematology and Clinical Chemistry Data for Rats in the Three-month Dermal Study of OTNE $^{\mathrm{a}}$

\begin{tabular}{|c|c|c|c|c|c|c|c|}
\hline & $\begin{array}{c}\text { Untreated } \\
\text { Control }\end{array}$ & $\begin{array}{l}\text { Vehicle } \\
\text { Control }\end{array}$ & $6.25 \%$ & $12.5 \%$ & $25 \%$ & $\mathbf{5 0 \%}$ & $100 \%$ \\
\hline \multicolumn{8}{|l|}{ Male } \\
\hline \multicolumn{8}{|l|}{ Hematology } \\
\hline \multicolumn{8}{|l|}{$\mathbf{n}$} \\
\hline Day 3 & 9 & 10 & 9 & 10 & 9 & 10 & 10 \\
\hline Day 23 & 10 & 10 & 9 & 10 & 10 & 9 & 10 \\
\hline Week 13 & 10 & 10 & 10 & 10 & 10 & 10 & 9 \\
\hline \multicolumn{8}{|c|}{ Hematocrit (auto) (\%) } \\
\hline Day 3 & $41.9 \pm 0.6$ & $41.5 \pm 0.6$ & $40.5 \pm 1.5$ & $41.7 \pm 0.5$ & $40.4 \pm 1.2$ & $40.5 \pm 1.3$ & $42.0 \pm 0.3$ \\
\hline Day 23 & $42.4 \pm 0.6$ & $42.1 \pm 0.5$ & $43.5 \pm 0.4$ & $42.5 \pm 0.8$ & $41.8 \pm 0.7$ & $43.2 \pm 0.3$ & $43.7 \pm 0.3$ \\
\hline Week 13 & $48.3 \pm 0.4$ & $48.1 \pm 1.2$ & $47.8 \pm 0.4$ & $48.0 \pm 0.5$ & $48.5 \pm 0.7$ & $47.6 \pm 0.7$ & $47.2 \pm 0.5$ \\
\hline \multicolumn{8}{|c|}{ Hematocrit (spun) (\%) } \\
\hline Day 3 & $48.3 \pm 0.5$ & $48.1 \pm 0.5$ & $49.2 \pm 1.0$ & $49.0 \pm 0.6$ & $48.3 \pm 0.8$ & $48.5 \pm 0.8$ & $49.2 \pm 0.4$ \\
\hline Day 23 & $50.7 \pm 0.5$ & $49.4 \pm 0.5$ & $51.4 \pm 0.5^{*}$ & $50.4 \pm 0.7$ & $50.1 \pm 0.7$ & $51.1 \pm 0.4$ & $51.3 \pm 0.5$ \\
\hline Week 13 & $50.5 \pm 0.6$ & $51.2 \pm 0.4$ & $50.4 \pm 0.4$ & $50.8 \pm 0.4$ & $51.0 \pm 0.4$ & $50.7 \pm 0.4$ & $50.2 \pm 0.5$ \\
\hline \multicolumn{8}{|c|}{ Hemoglobin $(\mathrm{g} / \mathrm{dL})$} \\
\hline Day 3 & $13.7 \pm 0.2$ & $13.5 \pm 0.2$ & $13.3 \pm 0.5$ & $13.7 \pm 0.1$ & $13.3 \pm 0.4$ & $13.3 \pm 0.4$ & $13.8 \pm 0.1$ \\
\hline Day 23 & $14.2 \pm 0.2$ & $14.1 \pm 0.2$ & $14.6 \pm 0.1$ & $14.2 \pm 0.3$ & $14.1 \pm 0.2$ & $14.5 \pm 0.1$ & $14.5 \pm 0.1$ \\
\hline Week 13 & $16.1 \pm 0.1$ & $15.9 \pm 0.4$ & $16.0 \pm 0.1$ & $16.0 \pm 0.2$ & $16.2 \pm 0.2$ & $15.9 \pm 0.2$ & $15.8 \pm 0.2$ \\
\hline \multicolumn{8}{|c|}{ Erythrocytes $\left(10^{6} / \mu \mathrm{L}\right)$} \\
\hline Day 3 & $7.23 \pm 0.09$ & $7.08 \pm 0.10$ & $6.97 \pm 0.23$ & $7.14 \pm 0.09$ & $6.94 \pm 0.19$ & $6.95 \pm 0.20$ & $7.19 \pm 0.05$ \\
\hline Day 23 & $7.66 \pm 0.10$ & $7.62 \pm 0.08$ & $7.79 \pm 0.08$ & $7.51 \pm 0.17$ & $7.53 \pm 0.11$ & $7.74 \pm 0.08$ & $7.83 \pm 0.07$ \\
\hline Week 13 & $9.64 \pm 0.08$ & $9.66 \pm 0.26$ & $9.47 \pm 0.10$ & $9.55 \pm 0.09$ & $9.69 \pm 0.13$ & $9.49 \pm 0.14$ & $9.51 \pm 0.11$ \\
\hline \multicolumn{8}{|c|}{ Erythrocyte distribution width (\%) } \\
\hline Day 3 & $15.50 \pm 0.38$ & $15.19 \pm 0.26$ & $16.19 \pm 0.32$ & $15.49 \pm 0.36$ & $16.73 \pm 0.31 *$ & $16.01 \pm 0.39$ & $15.91 \pm 0.47$ \\
\hline Day 23 & $13.29 \pm 0.13$ & $13.25 \pm 0.19$ & $13.03 \pm 0.10$ & $13.52 \pm 0.37$ & $13.33 \pm 0.13$ & $12.87 \pm 0.08$ & $13.50 \pm 0.08$ \\
\hline Week 13 & $12.83 \pm 0.13$ & $13.14 \pm 0.11$ & $12.78 \pm 0.11$ & $12.77 \pm 0.14$ & $12.99 \pm 0.08$ & $13.08 \pm 0.18$ & $13.01 \pm 0.08$ \\
\hline \multicolumn{8}{|c|}{ Reticulocytes (\%) } \\
\hline Day 3 & $3.99 \pm 0.26$ & $4.19 \pm 0.24$ & $4.02 \pm 0.17$ & $4.42 \pm 0.16$ & $4.19 \pm 0.12$ & $4.15 \pm 0.40$ & $4.58 \pm 0.29$ \\
\hline Day 23 & $3.48 \pm 0.21$ & $3.81 \pm 0.25$ & $2.94 \pm 0.15^{*}$ & $3.48 \pm 0.22$ & $3.16 \pm 0.11$ & $3.47 \pm 0.16$ & $3.46 \pm 0.15$ \\
\hline Week 13 & $2.86 \pm 0.23$ & $2.92 \pm 0.21$ & $3.07 \pm 0.18$ & $3.02 \pm 0.13$ & $3.18 \pm 0.12$ & $3.00 \pm 0.17$ & $2.92 \pm 0.10$ \\
\hline \multicolumn{8}{|c|}{ Reticulocytes $\left(10^{3} / \mu \mathrm{L}\right)$} \\
\hline Day 3 & $288 \pm 18$ & $296 \pm 16$ & $279 \pm 13$ & $316 \pm 14$ & $291 \pm 12$ & $286 \pm 26$ & $329 \pm 20$ \\
\hline Day 23 & $265 \pm 14$ & $292 \pm 21$ & $230 \pm 13$ & $258 \pm 11$ & $238 \pm 11$ & $268 \pm 12$ & $271 \pm 13$ \\
\hline Week 13 & $276 \pm 22$ & $282 \pm 21$ & $291 \pm 16$ & $288 \pm 12$ & $308 \pm 12$ & $284 \pm 15$ & $278 \pm 11$ \\
\hline \multicolumn{8}{|c|}{ Nucleated erythrocytes (/100 leukocytes) } \\
\hline Day 3 & $0.00 \pm 0.00$ & $0.00 \pm 0.00$ & $0.00 \pm 0.00$ & $0.00 \pm 0.00$ & $0.00 \pm 0.00$ & $0.00 \pm 0.00$ & $0.00 \pm 0.00$ \\
\hline Day 23 & $0.00 \pm 0.00$ & $0.00 \pm 0.00$ & $0.00 \pm 0.00$ & $0.00 \pm 0.00$ & $0.00 \pm 0.00$ & $0.00 \pm 0.00$ & $0.00 \pm 0.00$ \\
\hline Week 13 & $0.00 \pm 0.00$ & $0.00 \pm 0.00$ & $0.00 \pm 0.00$ & $0.00 \pm 0.00$ & $0.00 \pm 0.00$ & $0.00 \pm 0.00$ & $0.00 \pm 0.00$ \\
\hline
\end{tabular}


OTNE, NTP TOX 92

\begin{tabular}{|c|c|c|c|c|c|c|c|}
\hline & $\begin{array}{c}\text { Untreated } \\
\text { Control }\end{array}$ & $\begin{array}{l}\text { Vehicle } \\
\text { Control }\end{array}$ & $6.25 \%$ & $12.5 \%$ & $25 \%$ & $50 \%$ & $100 \%$ \\
\hline \multicolumn{8}{|c|}{ Mean cell volume (fL) } \\
\hline Day 3 & $58.0 \pm 0.3$ & $58.5 \pm 0.2$ & $58.0 \pm 0.4$ & $58.4 \pm 0.3$ & $58.3 \pm 0.2$ & $58.2 \pm 0.3$ & $58.3 \pm 0.3$ \\
\hline Day 23 & $55.3 \pm 0.2$ & $55.2 \pm 0.2$ & $55.7 \pm 0.2$ & $56.6 \pm 0.6$ & $55.6 \pm 0.3$ & $55.7 \pm 0.2$ & $55.9 \pm 0.4$ \\
\hline Week 13 & $50.1 \pm 0.2$ & $49.8 \pm 0.1$ & $50.5 \pm 0.2$ & $50.1 \pm 0.2$ & $50.1 \pm 0.2$ & $50.1 \pm 0.3$ & $49.7 \pm 0.2$ \\
\hline \multicolumn{8}{|c|}{ Mean cell hemoglobin (pg) } \\
\hline Day 3 & $18.9 \pm 0.1$ & $19.1 \pm 0.1$ & $19.1 \pm 0.1$ & $19.2 \pm 0.1$ & $19.1 \pm 0.1$ & $19.1 \pm 0.1$ & $19.2 \pm 0.1$ \\
\hline Day 23 & $18.5 \pm 0.1$ & $18.5 \pm 0.1$ & $18.7 \pm 0.1$ & $18.8 \pm 0.1$ & $18.7 \pm 0.1$ & $18.7 \pm 0.1$ & $18.5 \pm 0.1$ \\
\hline Week 13 & $16.7 \pm 0.1$ & $16.5 \pm 0.1$ & $16.9 \pm 0.1 * *$ & $16.8 \pm 0.1^{*}$ & $16.7 \pm 0.1$ & $16.7 \pm 0.1$ & $16.6 \pm 0.1$ \\
\hline \multicolumn{8}{|c|}{ Mean cell hemoglobin concentration (g/dL) } \\
\hline Day 3 & $32.6 \pm 0.1$ & $32.6 \pm 0.1$ & $32.9 \pm 0.2$ & $32.7 \pm 0.1$ & $32.9 \pm 0.2$ & $32.9 \pm 0.1$ & $32.9 \pm 0.1$ \\
\hline Day 23 & $33.5 \pm 0.1$ & $33.6 \pm 0.1$ & $33.5 \pm 0.1$ & $33.3 \pm 0.1$ & $33.6 \pm 0.1$ & $33.6 \pm 0.1$ & $33.2 \pm 0.1^{\dagger}$ \\
\hline Week 13 & $33.3 \pm 0.1$ & $33.1 \pm 0.1$ & $33.5 \pm 0.1^{*}$ & $33.4 \pm 0.1$ & $33.4 \pm 0.1$ & $33.5 \pm 0.1^{*}$ & $33.4 \pm 0.0$ \\
\hline \multicolumn{8}{|c|}{ Platelets $\left(10^{3} / \mu \mathrm{L}\right)$} \\
\hline Day 3 & $828 \pm 23$ & $806 \pm 17$ & $849 \pm 46$ & $830 \pm 12$ & $843 \pm 28$ & $831 \pm 15$ & $813 \pm 25$ \\
\hline Day 23 & $748 \pm 14$ & $764 \pm 15$ & $756 \pm 12$ & $782 \pm 39$ & $786 \pm 46$ & $773 \pm 20$ & $791 \pm 15^{\dagger}$ \\
\hline Week 13 & $632 \pm 17$ & $632 \pm 25$ & $602 \pm 13$ & $610 \pm 21$ & $664 \pm 12$ & $659 \pm 14$ & $715 \pm 18^{\dagger \dagger}$ \\
\hline \multicolumn{8}{|c|}{ Mean platelet volume (fL) } \\
\hline Day 3 & $6.811 \pm 0.070$ & $6.710 \pm 0.098$ & $7.267 \pm 0.365$ & $6.850 \pm 0.105$ & $7.111 \pm 0.063^{*}$ & $6.920 \pm 0.107$ & $7.040 \pm 0.120$ \\
\hline Day 23 & $6.290 \pm 0.081$ & $6.240 \pm 0.070$ & $6.244 \pm 0.112$ & $6.250 \pm 0.090$ & $6.420 \pm 0.073$ & $6.622 \pm 0.213$ & $6.440 \pm 0.088$ \\
\hline Week 13 & $6.310 \pm 0.050$ & $6.440 \pm 0.065$ & $6.290 \pm 0.043$ & $6.520 \pm 0.077$ & $6.460 \pm 0.064$ & $6.460 \pm 0.052$ & $6.589 \pm 0.101^{\dagger}$ \\
\hline \multicolumn{8}{|c|}{ Leukocytes $\left(10^{3} / \mu \mathrm{L}\right)$} \\
\hline Day 3 & $9.16 \pm 0.60$ & $8.88 \pm 0.40$ & $8.81 \pm 0.43$ & $10.29 \pm 0.36^{*}$ & $8.28 \pm 0.68$ & $8.88 \pm 0.40$ & $8.98 \pm 0.31$ \\
\hline Day 23 & $10.49 \pm 0.47$ & $10.39 \pm 0.41$ & $10.81 \pm 0.41$ & $11.64 \pm 1.12$ & $10.35 \pm 0.34$ & $10.00 \pm 0.32$ & $10.89 \pm 0.35$ \\
\hline Week 13 & $9.55 \pm 0.46$ & $10.13 \pm 0.45$ & $9.26 \pm 0.71$ & $9.80 \pm 0.48$ & $9.38 \pm 0.37$ & $9.96 \pm 0.33$ & $10.98 \pm 0.38^{\dagger}$ \\
\hline \multicolumn{8}{|c|}{ Segmented neutrophils $\left(10^{3} / \mu \mathrm{L}\right)$} \\
\hline Day 3 & $1.71 \pm 0.15$ & $1.80 \pm 0.09$ & $1.46 \pm 0.12$ & $2.02 \pm 0.11$ & $1.57 \pm 0.17$ & $1.69 \pm 0.12$ & $1.66 \pm 0.11$ \\
\hline Day 23 & $2.57 \pm 0.12$ & $2.47 \pm 0.17$ & $2.46 \pm 0.15$ & $3.08 \pm 0.64$ & $2.42 \pm 0.13$ & $2.12 \pm 0.15$ & $2.73 \pm 0.14$ \\
\hline Week 13 & $2.44 \pm 0.20$ & $2.57 \pm 0.19$ & $2.42 \pm 0.18$ & $2.60 \pm 0.12$ & $2.42 \pm 0.15$ & $2.84 \pm 0.15$ & $2.95 \pm 0.16$ \\
\hline \multicolumn{8}{|c|}{ Bands $\left(10^{3} / \mu \mathrm{L}\right)$} \\
\hline Day 3 & $0.00 \pm 0.00$ & $0.00 \pm 0.00$ & $0.00 \pm 0.00$ & $0.00 \pm 0.00$ & $0.00 \pm 0.00$ & $0.00 \pm 0.00$ & $0.00 \pm 0.00$ \\
\hline Day 23 & $0.00 \pm 0.00$ & $0.00 \pm 0.00$ & $0.00 \pm 0.00$ & $0.00 \pm 0.00$ & $0.00 \pm 0.00$ & $0.00 \pm 0.00$ & $0.00 \pm 0.00$ \\
\hline Week 13 & $0.00 \pm 0.00$ & $0.00 \pm 0.00$ & $0.00 \pm 0.00$ & $0.00 \pm 0.00$ & $0.00 \pm 0.00$ & $0.00 \pm 0.00$ & $0.00 \pm 0.00$ \\
\hline
\end{tabular}

Metamyelocytes $\left(10^{3} / \mu \mathrm{L}\right)$

$\begin{array}{llllllll}\text { Day } 3 & 0.000 \pm 0.000 & 0.000 \pm 0.000 & 0.000 \pm 0.000 & 0.000 \pm 0.000 & 0.000 \pm 0.000 & 0.000 \pm 0.000 & 0.000 \pm 0.000\end{array}$

$\begin{array}{llllllll}\text { Day } 23 & 0.000 \pm 0.000 & 0.000 \pm 0.000 & 0.000 \pm 0.000 & 0.000 \pm 0.000 & 0.000 \pm 0.000 & 0.000 \pm 0.000 & 0.000 \pm 0.000\end{array}$

$\begin{array}{llllllll}\text { Week } 13 & 0.000 \pm 0.000 & 0.000 \pm 0.000 & 0.000 \pm 0.000 & 0.000 \pm 0.000 & 0.000 \pm 0.000 & 0.000 \pm 0.000 & 0.000 \pm 0.000\end{array}$

Myelocytes $\left(10^{3} / \mu \mathrm{L}\right)$

$\begin{array}{llllllll}\text { Day } 3 & 0.000 \pm 0.000 & 0.000 \pm 0.000 & 0.000 \pm 0.000 & 0.000 \pm 0.000 & 0.000 \pm 0.000 & 0.000 \pm 0.000 & 0.000 \pm 0.000\end{array}$

$\begin{array}{llllllll}\text { Day } 23 & 0.000 \pm 0.000 & 0.000 \pm 0.000 & 0.000 \pm 0.000 & 0.000 \pm 0.000 & 0.000 \pm 0.000 & 0.000 \pm 0.000 & 0.000 \pm 0.000\end{array}$

$\begin{array}{llllllll}\text { Week } 13 & 0.000 \pm 0.000 & 0.000 \pm 0.000 & 0.000 \pm 0.000 & 0.000 \pm 0.000 & 0.000 \pm 0.000 & 0.000 \pm 0.000 & 0.000 \pm 0.000\end{array}$ 
OTNE, NTP TOX 92

\begin{tabular}{|c|c|c|c|c|c|c|c|}
\hline & $\begin{array}{c}\text { Untreated } \\
\text { Control }\end{array}$ & $\begin{array}{c}\text { Vehicle } \\
\text { Control } \\
\end{array}$ & $6.25 \%$ & $12.5 \%$ & $25 \%$ & $\mathbf{5 0 \%}$ & $100 \%$ \\
\hline \multicolumn{8}{|c|}{ Lymphocytes $\left(10^{3} / \mu \mathrm{L}\right)$} \\
\hline Day 3 & $7.03 \pm 0.42$ & $6.69 \pm 0.34$ & $7.00 \pm 0.40$ & $7.78 \pm 0.24$ & $6.35 \pm 0.52$ & $6.75 \pm 0.29$ & $6.96 \pm 0.22$ \\
\hline Day 23 & $7.43 \pm 0.35$ & $7.47 \pm 0.23$ & $7.85 \pm 0.24$ & $8.00 \pm 0.52$ & $7.41 \pm 0.43$ & $7.46 \pm 0.18$ & $7.60 \pm 0.25$ \\
\hline Week 13 & $6.61 \pm 0.30$ & $7.05 \pm 0.36$ & $6.37 \pm 0.54$ & $6.73 \pm 0.42$ & $6.48 \pm 0.26$ & $6.61 \pm 0.37$ & $7.37 \pm 0.29$ \\
\hline \multicolumn{8}{|c|}{ Atypical lymphocytes $\left(10^{3} / \mu \mathrm{L}\right)$} \\
\hline Day 3 & $0.00 \pm 0.00$ & $0.00 \pm 0.00$ & $0.00 \pm 0.00$ & $0.00 \pm 0.00$ & $0.00 \pm 0.00$ & $0.00 \pm 0.00$ & $0.00 \pm 0.00$ \\
\hline Day 23 & $0.00 \pm 0.00$ & $0.00 \pm 0.00$ & $0.00 \pm 0.00$ & $0.00 \pm 0.00$ & $0.00 \pm 0.00$ & $0.00 \pm 0.00$ & $0.00 \pm 0.00$ \\
\hline Week 13 & $0.00 \pm 0.00$ & $0.00 \pm 0.00$ & $0.00 \pm 0.00$ & $0.00 \pm 0.00$ & $0.00 \pm 0.00$ & $0.00 \pm 0.00$ & $0.00 \pm 0.00$ \\
\hline \multicolumn{8}{|c|}{ Monocytes $\left(10^{3} / \mu \mathrm{L}\right)$} \\
\hline Day 3 & $0.22 \pm 0.03$ & $0.21 \pm 0.01$ & $0.19 \pm 0.03$ & $0.27 \pm 0.02$ & $0.20 \pm 0.03$ & $0.20 \pm 0.02$ & $0.20 \pm 0.01$ \\
\hline Day 23 & $0.23 \pm 0.02$ & $0.20 \pm 0.02$ & $0.24 \pm 0.02$ & $0.28 \pm 0.06$ & $0.27 \pm 0.05$ & $0.17 \pm 0.01$ & $0.26 \pm 0.02$ \\
\hline Week 13 & $0.24 \pm 0.04$ & $0.25 \pm 0.03$ & $0.22 \pm 0.02$ & $0.23 \pm 0.02$ & $0.24 \pm 0.03$ & $0.26 \pm 0.02$ & $0.32 \pm 0.04$ \\
\hline \multicolumn{8}{|c|}{ Basophils $\left(10^{3} / \mu \mathrm{L}\right)$} \\
\hline Day 3 & $0.153 \pm 0.021$ & $0.144 \pm 0.014$ & $0.132 \pm 0.013$ & $0.179 \pm 0.015$ & $0.122 \pm 0.017$ & $0.194 \pm 0.022$ & $0.137 \pm 0.013$ \\
\hline Day 23 & $0.187 \pm 0.014$ & $0.175 \pm 0.012$ & $0.201 \pm 0.016$ & $0.212 \pm 0.030$ & $0.178 \pm 0.014$ & $0.173 \pm 0.016$ & $0.215 \pm 0.012$ \\
\hline Week 13 & $0.162 \pm 0.018$ & $0.190 \pm 0.018$ & $0.169 \pm 0.025$ & $0.169 \pm 0.017$ & $0.170 \pm 0.012$ & $0.175 \pm 0.018$ & $0.240 \pm 0.021^{\dagger}$ \\
\hline \multicolumn{8}{|c|}{ Eosinophils $\left(10^{3} / \mu \mathrm{L}\right)$} \\
\hline Day 3 & $0.04 \pm 0.01$ & $0.04 \pm 0.01$ & $0.02 \pm 0.00$ & $0.05 \pm 0.01$ & $0.03 \pm 0.00$ & $0.05 \pm 0.01$ & $0.03 \pm 0.01$ \\
\hline Day 23 & $0.07 \pm 0.01$ & $0.08 \pm 0.01$ & $0.07 \pm 0.01$ & $0.07 \pm 0.01$ & $0.07 \pm 0.01$ & $0.07 \pm 0.00$ & $0.08 \pm 0.01$ \\
\hline Week 13 & $0.09 \pm 0.01$ & $0.08 \pm 0.01$ & $0.08 \pm 0.01$ & $0.08 \pm 0.01$ & $0.08 \pm 0.01$ & $0.08 \pm 0.01$ & $0.10 \pm 0.01$ \\
\hline \multicolumn{8}{|c|}{ Clinical Chemistry } \\
\hline $\mathbf{n}$ & 10 & 10 & 10 & 10 & 10 & 10 & 10 \\
\hline \multicolumn{8}{|c|}{ Urea nitrogen $(\mathrm{mg} / \mathrm{dL})$} \\
\hline Day 3 & $13.6 \pm 1.1$ & $12.9 \pm 0.4$ & $14.2 \pm 0.7$ & $13.8 \pm 0.7$ & $12.9 \pm 0.7$ & $12.7 \pm 0.4$ & $12.0 \pm 0.4$ \\
\hline Day 23 & $14.3 \pm 0.7$ & $15.2 \pm 0.7$ & $14.0 \pm 0.8$ & $14.8 \pm 0.6$ & $13.9 \pm 0.7$ & $14.8 \pm 0.5$ & $14.7 \pm 0.4$ \\
\hline Week 13 & $18.9 \pm 0.6$ & $18.9 \pm 0.4$ & $18.0 \pm 0.5$ & $19.9 \pm 0.6$ & $19.4 \pm 0.6$ & $19.0 \pm 0.6$ & $19.2 \pm 0.4$ \\
\hline \multicolumn{8}{|c|}{ Creatinine (mg/dL) } \\
\hline Day 3 & $0.58 \pm 0.01$ & $0.59 \pm 0.01$ & $0.60 \pm 0.00$ & $0.60 \pm 0.01$ & $0.57 \pm 0.02$ & $0.60 \pm 0.00$ & $0.60 \pm 0.00$ \\
\hline Day 23 & $0.62 \pm 0.01$ & $0.62 \pm 0.01$ & $0.61 \pm 0.01$ & $0.60 \pm 0.01$ & $0.62 \pm 0.01$ & $0.65 \pm 0.02$ & $0.66 \pm 0.02$ \\
\hline Week 13 & $0.71 \pm 0.01$ & $0.72 \pm 0.01$ & $0.74 \pm 0.02$ & $0.74 \pm 0.02$ & $0.78 \pm 0.01 * *$ & $0.79 \pm 0.02 * *$ & $0.82 \pm 0.01^{\dagger \dagger}$ \\
\hline \multicolumn{8}{|c|}{ Total protein $(\mathrm{g} / \mathrm{dL})$} \\
\hline Day 3 & $5.8 \pm 0.1$ & $5.6 \pm 0.1$ & $5.8 \pm 0.1$ & $5.7 \pm 0.1$ & $5.7 \pm 0.1$ & $5.6 \pm 0.1$ & $5.6 \pm 0.1^{\dagger}$ \\
\hline Day 23 & $6.1 \pm 0.1$ & $6.2 \pm 0.1$ & $6.2 \pm 0.1$ & $6.2 \pm 0.1$ & $6.1 \pm 0.1$ & $6.2 \pm 0.1$ & $6.3 \pm 0.1$ \\
\hline Week 13 & $7.7 \pm 0.1$ & $7.7 \pm 0.1$ & $7.6 \pm 0.1$ & $7.6 \pm 0.1$ & $7.8 \pm 0.1$ & $7.7 \pm 0.1$ & $7.8 \pm 0.1$ \\
\hline \multicolumn{8}{|c|}{ Albumin (g/dL) } \\
\hline Day 3 & $3.6 \pm 0.0$ & $3.5 \pm 0.0$ & $3.6 \pm 0.0$ & $3.6 \pm 0.0$ & $3.5 \pm 0.0$ & $3.5 \pm 0.0$ & $3.5 \pm 0.0^{\dagger}$ \\
\hline Day 23 & $3.7 \pm 0.0$ & $3.7 \pm 0.0$ & $3.7 \pm 0.0$ & $3.6 \pm 0.1$ & $3.7 \pm 0.0$ & $3.7 \pm 0.0$ & $3.7 \pm 0.0$ \\
\hline Week 13 & $4.1 \pm 0.0$ & $4.1 \pm 0.0$ & $4.0 \pm 0.0$ & $4.1 \pm 0.0$ & $4.1 \pm 0.0$ & $4.1 \pm 0.1$ & $4.1 \pm 0.0$ \\
\hline \multicolumn{8}{|c|}{ Alanine aminotransferase (IU/L) } \\
\hline Day 3 & $81 \pm 2$ & $80 \pm 3$ & $78 \pm 3$ & $79 \pm 2$ & $77 \pm 2$ & $80 \pm 2$ & $81 \pm 2$ \\
\hline Day 23 & $54 \pm 1$ & $62 \pm 4$ & $56 \pm 2$ & $54 \pm 1$ & $123 \pm 71^{*}$ & $51 \pm 1 * *$ & $52 \pm 2$ \\
\hline Week 13 & $88 \pm 4$ & $91 \pm 8$ & $69 \pm 2 * *$ & $80 \pm 4^{*}$ & $67 \pm 2 * *$ & $61 \pm 2 * *$ & $54 \pm 1^{\dagger \dagger}$ \\
\hline
\end{tabular}


OTNE, NTP TOX 92

\begin{tabular}{|c|c|c|c|c|c|c|c|}
\hline & $\begin{array}{c}\text { Untreated } \\
\text { Control }\end{array}$ & $\begin{array}{l}\text { Vehicle } \\
\text { Control }\end{array}$ & $6.25 \%$ & $12.5 \%$ & $25 \%$ & $50 \%$ & $100 \%$ \\
\hline \multicolumn{8}{|c|}{ Alkaline phosphatase (IU/L) } \\
\hline Day 3 & $710 \pm 7$ & $695 \pm 12$ & $694 \pm 13$ & $697 \pm 16$ & $675 \pm 11$ & $700 \pm 13$ & $663 \pm 9^{\dagger \dagger}$ \\
\hline Day 23 & $564 \pm 13$ & $525 \pm 11$ & $529 \pm 11$ & $515 \pm 19$ & $475 \pm 23$ & $475 \pm 11^{*}$ & $477 \pm 9^{\dagger \dagger}$ \\
\hline Week 13 & $349 \pm 9$ & $373 \pm 10$ & $326 \pm 11^{*}$ & $346 \pm 11^{*}$ & $322 \pm 7 * *$ & $270 \pm 19 * *$ & $268 \pm 5^{\dagger \dagger}$ \\
\hline \multicolumn{8}{|c|}{ Creatine kinase (IU/L) } \\
\hline Day 3 & $953 \pm 88$ & $916 \pm 83$ & $905 \pm 95$ & $907 \pm 70$ & $992 \pm 114$ & $733 \pm 44$ & $748 \pm 68$ \\
\hline Day 23 & $772 \pm 123$ & $526 \pm 89^{b}$ & $964 \pm 372$ & $587 \pm 78$ & $597 \pm 80$ & $825 \pm 137$ & $650 \pm 87$ \\
\hline Week 13 & $224 \pm 26$ & $261 \pm 34$ & $346 \pm 48$ & $228 \pm 18$ & $282 \pm 43$ & $281 \pm 48$ & $336 \pm 56$ \\
\hline \multicolumn{8}{|c|}{ Sorbitol dehydrogenase (IU/L) } \\
\hline Day 3 & $28 \pm 2$ & $34 \pm 4$ & $37 \pm 3$ & $36 \pm 4$ & $29 \pm 4$ & $34 \pm 4$ & $32 \pm 5$ \\
\hline Day 23 & $32 \pm 4$ & $35 \pm 4$ & $37 \pm 4$ & $31 \pm 4$ & $57 \pm 20$ & $29 \pm 4$ & $33 \pm 5$ \\
\hline Week 13 & $56 \pm 3$ & $52 \pm 3$ & $44 \pm 2$ & $53 \pm 2$ & $52 \pm 2$ & $50 \pm 3$ & $45 \pm 4^{\dagger}$ \\
\hline \multicolumn{8}{|c|}{ Bile acids $(\mu \mathrm{mol} / \mathrm{L})$} \\
\hline Day 3 & $57.0 \pm 5.8$ & $51.2 \pm 6.7$ & $39.9 \pm 5.3$ & $50.2 \pm 6.8$ & $51.3 \pm 6.8$ & $48.4 \pm 6.8$ & $48.6 \pm 7.5$ \\
\hline Day 23 & $51.6 \pm 5.1$ & $55.6 \pm 4.5$ & $56.2 \pm 3.3$ & $53.2 \pm 3.9$ & $43.6 \pm 3.2^{*}$ & $44.0 \pm 3.7^{*}$ & $47.1 \pm 4.1$ \\
\hline Week 13 & $8.2 \pm 0.9$ & $10.5 \pm 1.9$ & $8.0 \pm 0.8$ & $8.5 \pm 1.7$ & $5.8 \pm 0.9 * *$ & $5.7 \pm 0.7 * *$ & $8.2 \pm 1.1$ \\
\hline
\end{tabular}

Female

Hematology

n

$\begin{array}{lccccccc}\text { Day } 3 & 10 & 10 & 10 & 10 & 10 & 10 & 10 \\ \text { Day } 23 & 9 & 9 & 9 & 9 & 9 & 10 & 9 \\ \text { Week } 13 & 10 & 10 & 10 & 10 & 10 & 10 & 10\end{array}$

Hematocrit (auto) (\%)

$\begin{array}{llllllll}\text { Day 3 } & 42.7 \pm 0.4 & 42.6 \pm 0.8 & 42.3 \pm 0.9 & 42.0 \pm 0.6 & 42.0 \pm 0.5 & 42.3 \pm 0.6 & 41.2 \pm 0.6 \\ \text { Day 23 } & 43.9 \pm 0.9 & 43.0 \pm 0.6 & 43.4 \pm 0.4 & 44.7 \pm 0.5 & 44.1 \pm 0.6 & 43.4 \pm 0.4 & 44.0 \pm 0.6 \\ \text { Week 13 } & 44.3 \pm 0.6 & 45.4 \pm 0.5 & 46.3 \pm 1.4 & 45.0 \pm 0.6 & 43.8 \pm 0.4 & 43.9 \pm 0.5 & 42.5 \pm 0.4^{\dagger}\end{array}$

Hematocrit (spun) (\%)

\begin{tabular}{|c|c|c|c|c|c|c|c|}
\hline Day 3 & $49.4 \pm 0.4$ & $49.1 \pm 0.8$ & $49.3 \pm 0.9$ & $48.9 \pm 0.6$ & $49.0 \pm 0.6$ & $49.6 \pm 0.8$ & $48.4 \pm 0.6$ \\
\hline Day 23 & $53.3 \pm 1.2$ & $52.4 \pm 0.8$ & $53.4 \pm 1.2$ & $53.7 \pm 0.8$ & $54.2 \pm 1.2$ & $52.5 \pm 0.9$ & $54.9 \pm 1.3$ \\
\hline Week 13 & $48.4 \pm 10.6$ & $49.4 \pm 0.3$ & $48.2 \pm 0.4$ & $49.1 \pm 0.5$ & $48.5 \pm 0.3$ & $48.0 \pm 0.5$ & $46.7 \pm 10.5^{\dagger}$ \\
\hline \multicolumn{8}{|c|}{ Hemoglobin (g/dL) } \\
\hline Day 3 & $14.6 \pm 0.1$ & $14.5 \pm 0.3$ & $14.6 \pm 0.3$ & $14.5 \pm 0.2$ & $14.5 \pm 0.2$ & $14.7 \pm 0.2$ & $14.3 \pm 0.2$ \\
\hline Day 23 & $15.4 \pm 0.3$ & $15.2 \pm 0.2$ & $15.3 \pm 0.1$ & $15.6 \pm 0.2$ & $15.5 \pm 0.2$ & $15.2 \pm 0.2$ & $15.4 \pm 0.2$ \\
\hline Week 13 & $15.3 \pm 0.2$ & $15.6 \pm 0.2$ & $15.9 \pm 0.4$ & $15.4 \pm 0.2$ & $15.1 \pm 0.1$ & $15.2 \pm 0.1$ & $14.7 \pm 0.1^{\dagger}$ \\
\hline \multicolumn{8}{|c|}{ Erythrocytes $\left(10^{6} / \mu \mathrm{L}\right)$} \\
\hline Day 3 & $7.69 \pm 0.08$ & $7.63 \pm 0.14$ & $7.68 \pm 0.16$ & $7.59 \pm 0.10$ & $7.53 \pm 0.09$ & $7.62 \pm 0.12$ & $7.40 \pm 0.11$ \\
\hline Day 23 & $8.13 \pm 0.18$ & $8.01 \pm 0.12$ & $8.03 \pm 0.08$ & $8.20 \pm 0.09$ & $8.14 \pm 0.10$ & $8.02 \pm 0.08$ & $8.06 \pm 0.11$ \\
\hline Week 13 & $8.38 \pm 0.12$ & $8.59 \pm 0.12$ & $8.73 \pm 0.23$ & $8.53 \pm 0.11$ & $8.35 \pm 0.09$ & $8.33 \pm 0.09$ & $8.01 \pm 0.08^{\dagger}$ \\
\hline \multicolumn{8}{|c|}{ Erythrocyte distribution width (\%) } \\
\hline Day 3 & $14.35 \pm 0.34$ & $14.26 \pm 0.19$ & $14.25 \pm 0.26$ & $14.45 \pm 0.26$ & $14.23 \pm 0.28$ & $14.30 \pm 0.37$ & $13.96 \pm 0.24$ \\
\hline Day 23 & $12.08 \pm 0.22$ & $12.08 \pm 0.11$ & $12.36 \pm 0.14$ & $12.26 \pm 0.12$ & $12.00 \pm 0.11$ & $12.14 \pm 0.08$ & $12.22 \pm 0.12$ \\
\hline Week 13 & $11.16 \pm 0.10$ & $11.17 \pm 0.06$ & $11.40 \pm 0.19$ & $11.21 \pm 0.08$ & $11.28 \pm 0.11$ & $11.11 \pm 0.13$ & $11.10 \pm 0.10$ \\
\hline
\end{tabular}


OTNE, NTP TOX 92

\begin{tabular}{|c|c|c|c|c|c|c|c|}
\hline & $\begin{array}{c}\text { Untreated } \\
\text { Control }\end{array}$ & $\begin{array}{l}\text { Vehicle } \\
\text { Control }\end{array}$ & $6.25 \%$ & $12.5 \%$ & $25 \%$ & $50 \%$ & $100 \%$ \\
\hline \multicolumn{8}{|c|}{ Reticulocytes (\%) } \\
\hline Day 3 & $3.86 \pm 0.31$ & $3.86 \pm 0.21$ & $3.77 \pm 0.22$ & $3.71 \pm 0.20$ & $3.97 \pm 0.19$ & $4.08 \pm 0.33$ & $3.66 \pm 0.17$ \\
\hline Day 23 & $2.87 \pm 0.17$ & $3.11 \pm 0.10$ & $2.82 \pm 0.11$ & $2.52 \pm 0.09^{* *}$ & $2.90 \pm 0.13$ & $3.03 \pm 0.19$ & $3.12 \pm 0.22$ \\
\hline Week 13 & $2.98 \pm 0.12$ & $2.89 \pm 0.10$ & $2.63 \pm 0.19$ & $3.22 \pm 0.14$ & $3.14 \pm 0.14$ & $3.04 \pm 0.18$ & $3.23 \pm 0.18$ \\
\hline \multicolumn{8}{|c|}{ Reticulocytes $\left(10^{3} / \mu \mathrm{L}\right)$} \\
\hline Day 3 & $295 \pm 21$ & $295 \pm 18$ & $290 \pm 20$ & $281 \pm 14$ & $299 \pm 15$ & $312 \pm 27$ & $271 \pm 13$ \\
\hline Day 23 & $233 \pm 15$ & $249 \pm 9$ & $226 \pm 10$ & $207 \pm 8^{*}$ & $235 \pm 11$ & $242 \pm 14$ & $252 \pm 20$ \\
\hline Week 13 & $250 \pm 10$ & $249 \pm 10$ & $230 \pm 19$ & $274 \pm 10$ & $262 \pm 12$ & $253 \pm 15$ & $259 \pm 14$ \\
\hline \multicolumn{8}{|c|}{ Nucleated erythrocytes (/100 leukocytes) } \\
\hline Day 3 & $0.0 \pm 0.0$ & $0.0 \pm 0.0$ & $0.0 \pm 0.0$ & $0.0 \pm 0.0$ & $0.0 \pm 0.0$ & $0.0 \pm 0.0$ & $0.0 \pm 0.0$ \\
\hline Day 23 & $0.0 \pm 0.0$ & $0.0 \pm 0.0$ & $0.0 \pm 0.0$ & $0.0 \pm 0.0$ & $0.0 \pm 0.0$ & $0.0 \pm 0.0$ & $0.0 \pm 0.0$ \\
\hline Week 13 & $0.0 \pm 0.0$ & $0.0 \pm 0.0$ & $0.0 \pm 0.0$ & $0.0 \pm 0.0$ & $0.0 \pm 0.0$ & $0.0 \pm 0.0$ & $0.0 \pm 0.0$ \\
\hline \multicolumn{8}{|c|}{ Mean cell volume (fL) } \\
\hline Day 3 & $55.4 \pm 0.2$ & $55.8 \pm 0.1$ & $55.2 \pm 0.2$ & $55.4 \pm 0.2$ & $55.8 \pm 0.2$ & $55.6 \pm 0.3$ & $55.6 \pm 0.3$ \\
\hline Day 23 & $54.1 \pm 0.2$ & $53.7 \pm 0.2$ & $53.9 \pm 0.2$ & $54.4 \pm 0.3$ & $54.2 \pm 0.2$ & $54.2 \pm 0.2$ & $54.4 \pm 0.3$ \\
\hline Week 13 & $52.8 \pm 0.1$ & $52.9 \pm 0.2$ & $53.1 \pm 0.3$ & $52.7 \pm 0.2$ & $52.4 \pm 0.2$ & $52.9 \pm 0.2$ & $53.0 \pm 0.2$ \\
\hline \multicolumn{8}{|c|}{ Mean cell hemoglobin (pg) } \\
\hline Day 3 & $19.0 \pm 0.1$ & $19.0 \pm 0.1$ & $19.0 \pm 0.1$ & $19.1 \pm 0.1$ & $19.3 \pm 0.1^{* *}$ & $19.3 \pm 0.1 *$ & $19.3 \pm 0.1^{\dagger}$ \\
\hline Day 23 & $19.0 \pm 0.1$ & $19.0 \pm 0.1$ & $19.1 \pm 0.1$ & $19.0 \pm 0.1$ & $19.0 \pm 0.1$ & $19.0 \pm 0.1$ & $19.1 \pm 0.2$ \\
\hline Week 13 & $18.2 \pm 0.1$ & $18.1 \pm 0.1$ & $18.2 \pm 0.1$ & $18.1 \pm 0.1$ & $18.1 \pm 0.1$ & $18.2 \pm 0.1$ & $18.3 \pm 0.1$ \\
\hline \multicolumn{8}{|c|}{ Mean cell hemoglobin concentration (g/dL) } \\
\hline Day 3 & $34.3 \pm 0.2$ & $34.0 \pm 0.1$ & $34.5 \pm 0.1 * *$ & $34.4 \pm 0.1^{*}$ & $34.5 \pm 0.1^{*}$ & $34.7 \pm 0.1^{* *}$ & $34.7 \pm 0.2$ \\
\hline Day 23 & $35.2 \pm 0.1$ & $35.2 \pm 0.1$ & $35.3 \pm 0.1$ & $34.9 \pm 0.1$ & $35.1 \pm 0.1$ & $35.0 \pm 0.1$ & $35.1 \pm 0.2$ \\
\hline Week 13 & $34.4 \pm 0.1$ & $34.3 \pm 0.1$ & $34.3 \pm 0.2$ & $34.3 \pm 0.1$ & $34.4 \pm 0.1$ & $34.5 \pm 0.1$ & $34.6 \pm 0.1$ \\
\hline \multicolumn{8}{|c|}{ Platelets $\left(10^{3} / \mu \mathrm{L}\right)$} \\
\hline Day 3 & $767 \pm 21$ & $759 \pm 22$ & $784 \pm 17$ & $726 \pm 21$ & $723 \pm 15$ & $745 \pm 19$ & $733 \pm 19$ \\
\hline Day 23 & $694 \pm 12$ & $682 \pm 23$ & $699 \pm 15$ & $688 \pm 20$ & $684 \pm 16$ & $688 \pm 20$ & $708 \pm 22$ \\
\hline Week 13 & $678 \pm 58$ & $612 \pm 17$ & $602 \pm 18$ & $621 \pm 9$ & $620 \pm 8$ & $669 \pm 21$ & $664 \pm 15$ \\
\hline
\end{tabular}

Mean platelet volume (fL)

\begin{tabular}{|c|c|c|c|c|c|c|c|}
\hline Day 3 & $6.500 \pm 0.065$ & $6.490 \pm 0.059$ & $6.470 \pm 0.073$ & $6.420 \pm 0.025$ & $6.350 \pm 0.031$ & $6.450 \pm 0.064$ & $6.490 \pm 0.098$ \\
\hline Day 23 & $6.389 \pm 0.123$ & $6.256 \pm 0.091$ & $6.378 \pm 0.080$ & $6.233 \pm 0.053$ & $6.333 \pm 0.075$ & $6.330 \pm 0.062$ & $6.467 \pm 0.188$ \\
\hline Week 13 & $6.290 \pm 0.064$ & $6.290 \pm 0.038$ & $6.350 \pm 0.081$ & $6.420 \pm 0.065$ & $6.400 \pm 0.077$ & $6.380 \pm 0.089$ & $6.290 \pm 0.086$ \\
\hline \multicolumn{8}{|c|}{ Leukocytes $\left(10^{3} / \mu \mathrm{L}\right)$} \\
\hline Day 3 & $10.14 \pm 0.30$ & $9.59 \pm 0.33$ & $9.53 \pm 0.57$ & $9.41 \pm 0.33$ & $9.85 \pm 0.51$ & $10.27 \pm 0.44$ & $9.59 \pm 0.51$ \\
\hline Day 23 & $10.64 \pm 0.92$ & $10.59 \pm 0.41$ & $10.74 \pm 0.26$ & $10.79 \pm 0.43$ & $10.52 \pm 0.70$ & $10.19 \pm 0.39$ & $9.82 \pm 0.47$ \\
\hline Week 13 & $9.18 \pm 0.72$ & $9.13 \pm 0.61$ & $7.92 \pm 0.47$ & $8.46 \pm 0.43$ & $8.89 \pm 0.30$ & $8.51 \pm 0.43$ & $8.93 \pm 0.63$ \\
\hline \multicolumn{8}{|c|}{ Segmented neutrophils $\left(10^{3} / \mu \mathrm{L}\right)$} \\
\hline Day 3 & $2.05 \pm 0.05$ & $2.02 \pm 0.10$ & $2.00 \pm 0.22$ & $2.02 \pm 0.07$ & $2.09 \pm 0.16$ & $2.15 \pm 0.1$ & $2.07 \pm 0.17$ \\
\hline Day 23 & $2.42 \pm 0.20$ & $2.30 \pm 0.08$ & $2.53 \pm 0.10$ & $2.48 \pm 0.07$ & $2.42 \pm 0.11$ & $2.42 \pm 0.11$ & $2.38 \pm 0.16$ \\
\hline Week 13 & $2.38 \pm 0.21$ & $2.49 \pm 0.25$ & $2.36 \pm 0.27$ & $2.30 \pm 0.19$ & $2.50 \pm 0.25$ & $2.34 \pm 0.09$ & $2.63 \pm 0.25$ \\
\hline
\end{tabular}


OTNE, NTP TOX 92

\begin{tabular}{lccccccc}
\hline & $\begin{array}{c}\text { Untreated } \\
\text { Control }\end{array}$ & $\begin{array}{c}\text { Vehicle } \\
\text { Control }\end{array}$ & $\mathbf{6 . 2 5 \%}$ & $\mathbf{1 2 . 5 \%}$ & $\mathbf{2 5 \%}$ & $\mathbf{5 0 \%}$ & $\mathbf{1 0 0 \%}$ \\
\hline Bands $\left(10^{3} / \mu \mathrm{L}\right)$ & & & & & & & \\
Day 3 & $0.00 \pm 0.00$ & $0.00 \pm 0.00$ & $0.00 \pm 0.00$ & $0.00 \pm 0.00$ & $0.00 \pm 0.00$ & $0.00 \pm 0.00$ & $0.00 \pm 0.00$ \\
Day 23 & $0.00 \pm 0.00$ & $0.00 \pm 0.00$ & $0.00 \pm 0.00$ & $0.00 \pm 0.00$ & $0.00 \pm 0.00$ & $0.00 \pm 0.00$ & $0.00 \pm 0.00$ \\
Week 13 & $0.00 \pm 0.00$ & $0.00 \pm 0.00$ & $0.00 \pm 0.00$ & $0.00 \pm 0.00$ & $0.00 \pm 0.00$ & $0.00 \pm 0.00$ & $0.00 \pm 0.00$
\end{tabular}

Metamyelocytes $\left(10^{3} / \mu \mathrm{L}\right)$

Day $3 \quad 0.000 \pm 0.000$

Day $23 \quad 0.000 \pm 0.000$

Week $13 \quad 0.000 \pm 0.000$

Myelocytes $\left(10^{3} / \mu \mathrm{L}\right)$

Day 3

$0.000 \pm 0.000$

Day 23

$0.000 \pm 0.000$

$0.000 \pm 0.000$

Week 13

$0.000 \pm 0.000$

Lymphocytes $\left(10^{3} / \mu \mathrm{L}\right)$

Day 3

$7.55 \pm 0.27$

Day 23

$7.68 \pm 0.68$

Week 13

$6.39 \pm 0.51$

$0.000 \pm 0.000$

$0.000 \pm 0.000$

$0.000 \pm 0.000 \quad 0.000 \pm 0.000$

$0.000 \pm 0.000 \quad 0.000 \pm 0.000$

0.000

000

$0.000 \pm 0.000 \quad 0.000 \pm 0.000$

Atypical lymphocytes $\left(10^{3} / \mu \mathrm{L}\right)$

Day 3

$0.00 \pm 0.00$

Day 23

$0.00 \pm 0.00$

$0.00 \pm 0.00$

$0.00 \pm 0.00$

$0.00 \pm 0.00$

$0.00 \pm 0.00$

$0.00 \pm 0.00$

$0.00 \pm 0.00$

$0.00 \pm 0.00$

$0.00 \pm 0.00$

Week 13

$0.00 \pm 0.00$

$0.00 \pm 0.00$

$0.00 \pm 0.00$

$0.00 \pm 0.00$

$0.00+0.00$

$.00 \pm 0.00$

$0.00 \pm 0.00$

Monocytes $\left(10^{3} / \mu \mathrm{L}\right)$

Day 3

$0.26 \pm 0.01$

$0.26 \pm 0.02$

$0.19 \pm 0.02$

$0.22 \pm 0.02$

$0.24 \pm 0.03$

$0.21 \pm 0.02$

$0.19 \pm 0.01$

$0.22 \pm 0.03$

$0.22 \pm 0.02$

$0.24 \pm 0.03$

$0.20 \pm 0.03^{\dagger}$

Day 23

$0.20 \pm 0.03$

$0.22 \pm 0.04$

$0.17 \pm 0.02$

$0.19 \pm 0.02$

$0.19 \pm 0.02$

$0.21 \pm 0.01$

$0.21 \pm 0.02$

Basophils $\left(10^{3} / \mu \mathrm{L}\right)$

Day 3

Day 23

$0.229 \pm 0.011$

$0.202 \pm 0.012$

$0.186 \pm 0.018 \quad 0.215 \pm 0.020$

$0.220+0.014$

$0.18 \pm 0.02$

$0.22 \pm 0.04$

$0.183 \pm 0.028$ $0.145 \pm 0.022 \quad 0.153 \pm 0.015 \quad 0.166 \pm 0.023 \quad 0.149 \pm 0.016 \quad 0.170 \pm 0.024$

Eosinophils $\left(10^{3} / \mu \mathrm{L}\right)$

\begin{tabular}{llllllll} 
Day 3 & $0.05 \pm 0.01$ & $0.04 \pm 0.00$ & $0.06 \pm 0.01$ & $0.05 \pm 0.01$ & $0.06 \pm 0.01$ & $0.07 \pm 0.01$ & $0.06 \pm 0.01$ \\
Day 23 & $0.09 \pm 0.01$ & $0.08 \pm 0.01$ & $0.09 \pm 0.01$ & $0.08 \pm 0.01$ & $0.09 \pm 0.01$ & $0.08 \pm 0.01$ & $0.08 \pm 0.01$ \\
Week 13 & $0.07 \pm 0.01$ & $0.08 \pm 0.01$ & $0.07 \pm 0.01$ & $0.06 \pm 0.01$ & $0.07 \pm 0.01$ & $0.06 \pm 0.01$ & $0.07 \pm 0.01$ \\
\hline
\end{tabular}

\section{Clinical Chemistry}

\begin{tabular}{|c|c|c|c|c|c|c|c|}
\hline $\mathbf{n}$ & 10 & 10 & 10 & 10 & 10 & 10 & 10 \\
\hline \multicolumn{8}{|c|}{ Urea nitrogen (mg/dL) } \\
\hline Day 3 & $14.1 \pm 0.6$ & $13.6 \pm 0.8$ & $15.2 \pm 0.9$ & $15.2 \pm 0.7$ & $13.6 \pm 0.5$ & $14.0 \pm 0.6$ & $13.8 \pm 0.7$ \\
\hline Day 23 & $17.8 \pm 0.9$ & $17.8 \pm 1.1$ & $18.4 \pm 0.9$ & $18.3 \pm 0.8$ & $18.3 \pm 0.6$ & $18.4 \pm 0.7$ & $17.3 \pm 0.5$ \\
\hline Week 13 & $20.4 \pm 0.6$ & $21.1 \pm 0.6$ & $22.0 \pm 0.6$ & $22.7 \pm 0.7$ & $21.1 \pm 1.0$ & $21.2 \pm 1.1$ & $20.6 \pm 1.0$ \\
\hline \multicolumn{8}{|c|}{ Creatinine (mg/dL) } \\
\hline Day 3 & $0.60 \pm 0.00$ & $0.59 \pm 0.01$ & $0.61 \pm 0.02$ & $0.59 \pm 0.01$ & $0.60 \pm 0.00$ & $0.61 \pm 0.01$ & $0.61 \pm 0.01$ \\
\hline Day 23 & $0.64 \pm 0.02$ & $0.63 \pm 0.02$ & $0.62 \pm 0.01$ & $0.65 \pm 0.02$ & $0.64 \pm 0.02$ & $0.65 \pm 0.02$ & $0.66 \pm 0.02$ \\
\hline Week 13 & $0.72 \pm 0.01$ & $0.66 \pm 0.02$ & $0.69 \pm 0.02$ & $0.68 \pm 0.06$ & $0.68 \pm 0.01$ & $0.68 \pm 0.01$ & $0.71 \pm 0.02$ \\
\hline
\end{tabular}


OTNE, NTP TOX 92

\begin{tabular}{|c|c|c|c|c|c|c|c|}
\hline & $\begin{array}{c}\text { Untreated } \\
\text { Control }\end{array}$ & $\begin{array}{l}\text { Vehicle } \\
\text { Control }\end{array}$ & $6.25 \%$ & $12.5 \%$ & $25 \%$ & $50 \%$ & $100 \%$ \\
\hline \multicolumn{8}{|c|}{ Total protein $(\mathrm{g} / \mathrm{dL})$} \\
\hline Day 3 & $5.6 \pm 0.1$ & $5.5 \pm 0.2$ & $5.6 \pm 0.2$ & $5.4 \pm 0.1$ & $5.5 \pm 0.0$ & $5.6 \pm 0.1$ & $5.4 \pm 0.1^{\dagger}$ \\
\hline Day 23 & $6.3 \pm 0.1$ & $6.3 \pm 0.1$ & $6.2 \pm 0.1$ & $6.3 \pm 0.1$ & $6.4 \pm 0.1$ & $6.3 \pm 0.1$ & $6.4 \pm 0.1$ \\
\hline Week 13 & $7.2 \pm 0.1$ & $7.1 \pm 0.1$ & $7.2 \pm 0.1$ & $7.6 \pm 0.1^{*}$ & $7.3 \pm 0.1$ & $7.3 \pm 0.1$ & $7.4 \pm 0.1$ \\
\hline \multicolumn{8}{|c|}{ Albumin (g/dL) } \\
\hline Day 3 & $3.6 \pm 0.0$ & $3.6 \pm 0.1$ & $3.6 \pm 0.1$ & $3.6 \pm 0.0$ & $3.6 \pm 0.0$ & $3.6 \pm 0.1$ & $3.5 \pm 0.1$ \\
\hline Day 23 & $3.9 \pm 0.1$ & $3.8 \pm 0.0$ & $3.8 \pm 0.0$ & $3.9 \pm 0.1$ & $3.9 \pm 0.1$ & $3.8 \pm 0.1$ & $3.8 \pm 0.0$ \\
\hline Week 13 & $4.0 \pm 0.1$ & $4.0 \pm 0.1$ & $4.1 \pm 0.1$ & $4.0 \pm 0.2$ & $4.0 \pm 0.1$ & $4.0 \pm 0.1$ & $4.0 \pm 0.1$ \\
\hline \multicolumn{8}{|c|}{ Alanine aminotransferase (IU/L) } \\
\hline Day 3 & $69 \pm 2$ & $62 \pm 2$ & $62 \pm 3$ & $65 \pm 2$ & $67 \pm 1$ & $67 \pm 1$ & $68 \pm 2$ \\
\hline Day 23 & $52 \pm 1$ & $49 \pm 1$ & $49 \pm 1$ & $50 \pm 2$ & $50 \pm 2$ & $52 \pm 2$ & $50 \pm 2$ \\
\hline Week 13 & $70 \pm 2$ & $74 \pm 4$ & $71 \pm 3$ & $65 \pm 2$ & $58 \pm 2 * *$ & $55 \pm 3 * *$ & $50 \pm 1^{\dagger \dagger}$ \\
\hline \multicolumn{8}{|c|}{ Alkaline phosphatase (IU/L) } \\
\hline Day 3 & $679 \pm 17$ & $626 \pm 17$ & $628 \pm 12$ & $650 \pm 11$ & $640 \pm 14$ & $642 \pm 13$ & $576 \pm 16^{\dagger \dagger}$ \\
\hline Day 23 & $471 \pm 9$ & $462 \pm 11$ & $479 \pm 12$ & $471 \pm 9$ & $446 \pm 15$ & $438 \pm 11$ & $395 \pm 7^{\dagger \dagger}$ \\
\hline Week 13 & $350 \pm 13$ & $360 \pm 13$ & $334 \pm 28$ & $367 \pm 13$ & $344 \pm 13$ & $282 \pm 7 * *$ & $259 \pm 10^{\dagger \dagger}$ \\
\hline \multicolumn{8}{|c|}{ Creatine kinase (IU/L) } \\
\hline Day 3 & $661 \pm 43$ & $633 \pm 65$ & $876 \pm 56^{*}$ & $676 \pm 53$ & $541 \pm 45$ & $729 \pm 46$ & $666 \pm 80$ \\
\hline Day 23 & $723 \pm 181$ & $733 \pm 75$ & $984 \pm 148$ & $556 \pm 114$ & $862 \pm 110$ & $928 \pm 141$ & $806 \pm 163$ \\
\hline Week 13 & $326 \pm 63$ & $325 \pm 29$ & $257 \pm 38$ & $250 \pm 30$ & $326 \pm 58$ & $277 \pm 32$ & $244 \pm 41$ \\
\hline \multicolumn{8}{|c|}{ Sorbitol dehydrogenase (IU/L) } \\
\hline Day 3 & $41 \pm 3$ & $40 \pm 3$ & $33 \pm 4$ & $40 \pm 4$ & $46 \pm 3$ & $42 \pm 3$ & $40 \pm 4$ \\
\hline Day 23 & $41 \pm 4$ & $38 \pm 3$ & $31 \pm 4$ & $49 \pm 6$ & $36 \pm 5$ & $36 \pm 6$ & $39 \pm 5$ \\
\hline Week 13 & $56 \pm 5$ & $49 \pm 5$ & $52 \pm 5$ & $58 \pm 3$ & $47 \pm 3$ & $49 \pm 5$ & $46 \pm 4$ \\
\hline \multicolumn{8}{|c|}{ Bile acids $(\mu \mathrm{mol} / \mathrm{L})$} \\
\hline Day 3 & $24.6 \pm 1.9$ & $33.4 \pm 4.4$ & $30.3 \pm 2.9$ & $28.0 \pm 4.7$ & $27.4 \pm 3.9$ & $26.7 \pm 3.9$ & $23.3 \pm 5.2$ \\
\hline Day 23 & $34.8 \pm 4.4$ & $31.3 \pm 5.2$ & $38.1 \pm 4.9$ & $33.8 \pm 4.1$ & $29.8 \pm 3.2$ & $34.0 \pm 1.9$ & $30.1 \pm 1.6$ \\
\hline Week 13 & $24.8 \pm 4.2$ & $21.7 \pm 3.0$ & $26.7 \pm 4.6$ & $19.0 \pm 2.0$ & $18.3 \pm 1.5$ & $14.5 \pm 1.0$ & $14.7 \pm 0.8^{\dagger}$ \\
\hline
\end{tabular}

*Significantly different $(\mathrm{P} \leq 0.05)$ from the vehicle control group by Dunn's or Shirley's test.

$* * \mathrm{P} \leq 0.01$.

$\dagger$ Significantly different $(\mathrm{P} \leq 0.05)$ from the untreated control group by Wilcoxon's rank sum test.

$\dagger+\mathrm{P} \leq 0.01$.

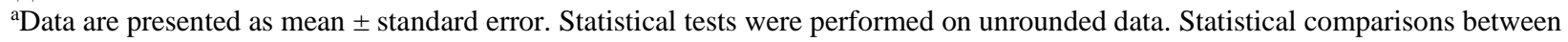
the two control groups are not presented.

$\mathrm{b}_{\mathrm{n}}=9$. 
OTNE, NTP TOX 92

Table B-2. Protein Yield and CYP2E1 Activity in the Liver of Rats in the Three-month Dermal Study of OTNE

\begin{tabular}{|c|c|c|c|c|c|c|c|}
\hline & $\begin{array}{c}\text { Untreated } \\
\text { Control }\end{array}$ & $\begin{array}{l}\text { Vehicle } \\
\text { Control }\end{array}$ & $6.25 \%$ & $12.5 \%$ & $25 \%$ & $50 \%$ & $100 \%$ \\
\hline $\mathbf{n}$ & 5 & 5 & 5 & 5 & 5 & 5 & 5 \\
\hline \multicolumn{8}{|l|}{ Male } \\
\hline \multicolumn{8}{|c|}{ Total microsomal protein ( $\mathrm{mg} / \mathrm{kg}$ liver) } \\
\hline Day 23 & $13.28 \pm 1.62$ & $10.81 \pm 0.76$ & $13.69 \pm 1.72$ & $11.74 \pm 1.09$ & $15.08 \pm 1.11^{*}$ & $18.10 \pm 0.93 * *$ & $18.82 \pm 2.32$ \\
\hline Week 13 & $10.004 \pm 0.370$ & $13.51 \pm 1.818$ & $14.200 \pm 1.243$ & $13.414 \pm 1.138$ & $12.300 \pm 0.628$ & $10.938 \pm 1.044^{\mathrm{b}}$ & $11.338 \pm 0.819$ \\
\hline \multicolumn{8}{|c|}{ CYP2E1 liver activity (nmol/minute per mg protein) } \\
\hline Day 23 & $0.443 \pm 0.035$ & $0.403 \pm 0.058$ & $0.437 \pm 0.024$ & $0.446 \pm 0.047$ & $0.454 \pm 0.026$ & $0.432 \pm 0.029$ & $0.414 \pm 0.017$ \\
\hline Week 13 & $0.472 \pm 0.022$ & $0.419 \pm 0.030$ & $0.497 \pm 0.032$ & $0.452 \pm 0.011$ & $0.414 \pm 0.026$ & $0.527 \pm 0.086$ & $0.555 \pm 0.819$ \\
\hline
\end{tabular}

\section{Female}

Total microsomal protein $(\mathrm{mg} / \mathrm{kg}$ liver)

$\begin{array}{lccccccc}\text { Day 23 } & 13.20 \pm 1.54 & 15.70 \pm 0.74 & 11.64 \pm 0.47 * & 14.96 \pm 1.15 & 15.46 \pm 1.28 & 15.56 \pm 0.54 & 16.42 \pm 1.34 \\ \text { Week 13 } & 7.686 \pm 0.657 & 7.412 \pm 0.610 & 8.342 \pm 0.509 & 9.344 \pm 0.169 * & 10.496 \pm 0.849 * * & 13.280 \pm 0.684 * * & 12.100 \pm 0.5366^{\dagger \dagger}\end{array}$

CYP2E1 liver activity (nmol/minute per $\mathrm{mg}$ protein)

$\begin{array}{llllllll}\text { Day 23 } & 0.227 \pm 0.020 & 0.216 \pm 0.034 & 0.232 \pm 0.018 & 0.270 \pm 0.032 & 0.247 \pm 0.053 & 0.225 \pm 0.026 & 0.286 \pm 0.027 \\ \text { Week 13 } & 0.528 \pm 0.097 & 0.336 \pm 0.022 & 0.336 \pm 0.021 & 0.365 \pm 0.018 & 0.362 \pm 0.020 & 0.370 \pm 0.030 & 0.470 \pm 0.050\end{array}$

*Significantly different $(\mathrm{P} \leq 0.05)$ from the vehicle control group by Dunn's or Shirley's test.

$* * \mathrm{P} \leq 0.01$.

${ }^{\dagger}$ Significantly different $(\mathrm{P} \leq 0.01)$ from the untreated control group by Wilcoxon's rank sum test.

${ }^{a}$ Data are presented as mean \pm standard error. Statistical comparisons between the two control groups are not presented.

${ }^{b} \mathrm{n}=4$. 
OTNE, NTP TOX 92

Table B-3. Hematology Data for Mice in the Three-month Dermal Study of OTNE

\begin{tabular}{|c|c|c|c|c|c|c|}
\hline $\begin{array}{c}\text { Untreated } \\
\text { Control }\end{array}$ & $\begin{array}{l}\text { Vehicle } \\
\text { Control }\end{array}$ & $6.25 \%$ & $12.5 \%$ & $25 \%$ & $50 \%$ & $100 \%$ \\
\hline \multicolumn{7}{|l|}{ Male } \\
\hline 10 & 10 & 10 & 10 & 10 & 10 & 10 \\
\hline \multicolumn{7}{|l|}{ Hematocrit (auto) (\%) } \\
\hline $52.3 \pm 0.9$ & $53.3 \pm 0.7$ & $52.0 \pm 1.3$ & $51.2 \pm 0.9$ & $48.7 \pm 0.8 * *$ & $49.1 \pm 0.8 * *$ & $45.7 \pm 0.8^{\dagger \dagger}$ \\
\hline \multicolumn{7}{|l|}{ Hematocrit (spun) (\%) } \\
\hline $52.9 \pm 1.0$ & $54.5 \pm 0.7$ & $53.7 \pm 1.4$ & $51.8 \pm 0.7^{*}$ & $49.7 \pm 1.1 * *$ & $51.3 \pm 0.9 * *$ & $47.6 \pm 1.1^{\dagger \dagger}$ \\
\hline \multicolumn{7}{|l|}{ Hemoglobin (g/dL) } \\
\hline $16.7 \pm 0.4$ & $17.0 \pm 0.2$ & $16.7 \pm 0.4$ & $16.5 \pm 0.3$ & $15.7 \pm 0.3 * *$ & $16.0 \pm 0.2 * *$ & $15.0 \pm 0.3^{\dagger \dagger}$ \\
\hline \multicolumn{7}{|l|}{ Erythrocytes $\left(10^{6} / \mu \mathrm{L}\right)$} \\
\hline $10.76 \pm 0.22$ & $10.84 \pm 0.13$ & $10.56 \pm 0.24$ & $10.45 \pm 0.17$ & $9.94 \pm 0.16^{* *}$ & $9.98 \pm 0.16^{* *}$ & $9.26 \pm 0.13^{\dagger \dagger}$ \\
\hline \multicolumn{7}{|l|}{ Erythrocyte distribution width (\%) } \\
\hline $12.63 \pm 0.18$ & $12.17 \pm 0.07$ & $12.53 \pm 0.11$ & $12.34 \pm 0.11$ & $12.67 \pm 0.13^{* *}$ & $12.92 \pm 0.15^{* *}$ & $13.42 \pm 0.12^{\dagger \dagger}$ \\
\hline \multicolumn{7}{|l|}{ Reticulocytes (\%) } \\
\hline $3.030 \pm 0.141$ & $3.37 \pm 0.12$ & $3.27 \pm 0.16$ & $2.90 \pm 0.18$ & $3.10 \pm 0.25$ & $3.06 \pm 0.14$ & $3.100 \pm 0.190$ \\
\hline \multicolumn{7}{|l|}{ Reticulocytes $\left(10^{3} / \mu \mathrm{L}\right)$} \\
\hline $325 \pm 15$ & $366 \pm 16$ & $346 \pm 19$ & $305 \pm 23$ & $308 \pm 26$ & $304 \pm 11$ & $287 \pm 19$ \\
\hline \multicolumn{7}{|c|}{ Nucleated erythrocytes (/100 leukocytes) } \\
\hline $0.0 \pm 0.0$ & $0.00 \pm 0.00$ & $0.00 \pm 0.00$ & $0.00 \pm 0.00$ & $0.00 \pm 0.00$ & $0.00 \pm 0.00$ & $0.0 \pm 0.0$ \\
\hline \multicolumn{7}{|l|}{ Mean cell volume (fL) } \\
\hline $48.6 \pm 0.3$ & $49.2 \pm 0.2$ & $49.2 \pm 0.2$ & $48.9 \pm 0.2$ & $48.9 \pm 0.1$ & $49.2 \pm 0.2$ & $49.3 \pm 0.3$ \\
\hline \multicolumn{7}{|l|}{ Mean cell hemoglobin (pg) } \\
\hline $15.5 \pm 0.1$ & $15.7 \pm 0.0$ & $15.8 \pm 0.1$ & $15.8 \pm 0.1$ & $15.8 \pm 0.0$ & $16.0 \pm 0.0 * *$ & $16.2 \pm 0.1^{\dagger \dagger}$ \\
\hline \multicolumn{7}{|c|}{ Mean cell hemoglobin concentration (g/dL) } \\
\hline $31.9 \pm 0.2$ & $31.9 \pm 0.1$ & $32.1 \pm 0.1$ & $32.2 \pm 0.2$ & $32.2 \pm 0.1 *$ & $32.5 \pm 0.1^{* *}$ & $32.7 \pm 0.1^{\dagger \dagger}$ \\
\hline \multicolumn{7}{|l|}{ Platelets $\left(10^{3} / \mu \mathrm{L}\right)$} \\
\hline $688 \pm 21$ & $666 \pm 23$ & $620 \pm 31$ & $663 \pm 26$ & $716 \pm 31$ & $747 \pm 16^{*}$ & $843 \pm 37^{\dagger \dagger}$ \\
\hline \multicolumn{7}{|l|}{ Mean platelet volume (fL) } \\
\hline $5.490 \pm 0.120$ & $5.490 \pm 0.041$ & $5.360 \pm 0.108$ & $5.460 \pm 0.064$ & $5.570 \pm 0.122$ & $5.540 \pm 0.070$ & $5.410 \pm 0.043$ \\
\hline \multicolumn{7}{|l|}{ Leukocytes $\left(10^{3} / \mu \mathrm{L}\right)$} \\
\hline $5.48 \pm 0.59$ & $6.22 \pm 0.43$ & $5.47 \pm 0.50$ & $5.96 \pm 0.66$ & $5.30 \pm 0.59$ & $6.51 \pm 0.54$ & $5.78 \pm 0.62$ \\
\hline \multicolumn{7}{|l|}{ Segmented neutrophils $\left(10^{3} / \mu \mathrm{L}\right)$} \\
\hline $1.23 \pm 0.14$ & $1.45 \pm 0.10$ & $1.29 \pm 0.14$ & $1.47 \pm 0.17$ & $1.22 \pm 0.13$ & $1.71 \pm 0.21$ & $1.87 \pm 0.33$ \\
\hline \multicolumn{7}{|l|}{ Bands $\left(10^{3} / \mu \mathrm{L}\right)$} \\
\hline $0.00 \pm 0.00$ & $0.00 \pm 0.00$ & $0.00 \pm 0.00$ & $0.00 \pm 0.00$ & $0.00 \pm 0.00$ & $0.00 \pm 0.00$ & $0.00 \pm 0.00$ \\
\hline \multicolumn{7}{|l|}{ Metamyelocytes $\left(10^{3} / \mu \mathrm{L}\right)$} \\
\hline $0.000 \pm 0.000$ & $0.000 \pm 0.000$ & $0.000 \pm 0.000$ & $0.000 \pm 0.000$ & $0.000 \pm 0.000$ & $0.000 \pm 0.000$ & $0.000 \pm 0.000$ \\
\hline \multicolumn{7}{|l|}{ Myelocytes $\left(10^{3} / \mu \mathrm{L}\right)$} \\
\hline $0.000 \pm 0.000$ & $0.000 \pm 0.000$ & $0.000 \pm 0.000$ & $0.000 \pm 0.000$ & $0.000 \pm 0.000$ & $0.000 \pm 0.000$ & $0.000 \pm 0.000$ \\
\hline \multicolumn{7}{|l|}{ Lymphocytes $\left(10^{3} / \mu \mathrm{L}\right)$} \\
\hline $4.19 \pm 0.47$ & $4.71 \pm 0.33$ & $4.13 \pm 0.36$ & $4.43 \pm 0.49$ & $4.01 \pm 0.47$ & $4.72 \pm 0.42$ & $3.83 \pm 0.36$ \\
\hline
\end{tabular}


OTNE, NTP TOX 92

\begin{tabular}{|c|c|c|c|c|c|c|}
\hline $\begin{array}{c}\text { Untreated } \\
\text { Control }\end{array}$ & $\begin{array}{l}\text { Vehicle } \\
\text { Control }\end{array}$ & $6.25 \%$ & $12.5 \%$ & $25 \%$ & $\mathbf{5 0 \%}$ & $100 \%$ \\
\hline \multicolumn{7}{|l|}{ Atypical lymphocytes $\left(10^{3} / \mu \mathrm{L}\right)$} \\
\hline $0.00 \pm 0.00$ & $0.00 \pm 0.00$ & $0.00 \pm 0.00$ & $0.00 \pm 0.00$ & $0.00 \pm 0.00$ & $0.00 \pm 0.00$ & $0.00 \pm 0.00$ \\
\hline \multicolumn{7}{|l|}{ Monocytes $\left(10^{3} / \mu \mathrm{L}\right)$} \\
\hline $0.04 \pm 0.01$ & $0.04 \pm 0.00$ & $0.04 \pm 0.01$ & $0.05 \pm 0.01$ & $0.05 \pm 0.01$ & $0.06 \pm 0.01 *$ & $0.06 \pm 0.01$ \\
\hline \multicolumn{7}{|l|}{ Basophils $\left(10^{3} / \mu \mathrm{L}\right)$} \\
\hline $0.007 \pm 0.002$ & $0.008 \pm 0.001$ & $0.003 \pm 0.002$ & $0.004 \pm 0.002$ & $0.004 \pm 0.002$ & $0.005 \pm 0.002$ & $0.008 \pm 0.001$ \\
\hline \multicolumn{7}{|l|}{ Eosinophils $\left(10^{3} / \mu \mathrm{L}\right)$} \\
\hline $0.01 \pm 0.00$ & $0.02 \pm 0.00$ & $0.01 \pm 0.00$ & $0.02 \pm 0.01$ & $0.02 \pm 0.00$ & $0.02 \pm 0.01$ & $0.01 \pm 0.00$ \\
\hline \multicolumn{7}{|l|}{ Female } \\
\hline 10 & 10 & 10 & 10 & 10 & 10 & 10 \\
\hline \multicolumn{7}{|l|}{ Hematocrit (auto) (\%) } \\
\hline $50.4 \pm 2.2$ & $48.7 \pm 1.9$ & $48.0 \pm 1.5$ & $49.7 \pm 1.2$ & $49.3 \pm 0.4$ & $46.4 \pm 0.7$ & $43.6 \pm 1.1^{\dagger}$ \\
\hline \multicolumn{7}{|l|}{ Hematocrit (spun) (\%) } \\
\hline $54.9 \pm 1.3$ & $52.2 \pm 1.0$ & $51.3 \pm 0.4$ & $51.5 \pm 1.2$ & $51.0 \pm 0.6$ & $48.1 \pm 0.5 * *$ & $46.9 \pm 0.7^{\dagger \dagger}$ \\
\hline \multicolumn{7}{|l|}{ Hemoglobin (g/dL) } \\
\hline $16.5 \pm 0.7$ & $15.9 \pm 0.6$ & $15.9 \pm 0.5$ & $16.3 \pm 0.4$ & $16.3 \pm 0.2$ & $15.4 \pm 0.2$ & $14.6 \pm 0.4^{\dagger}$ \\
\hline \multicolumn{7}{|l|}{ Erythrocytes $\left(10^{6} / \mu \mathrm{L}\right)$} \\
\hline $10.42 \pm 0.45$ & $10.04 \pm 0.36$ & $9.93 \pm 0.29$ & $10.13 \pm 0.22$ & $10.16 \pm 0.11$ & $9.48 \pm 0.10$ & $8.93 \pm 0.22^{\dagger \dagger}$ \\
\hline \multicolumn{7}{|l|}{ Erythrocyte distribution width (\%) } \\
\hline $12.21 \pm 0.14$ & $12.24 \pm 0.08$ & $12.61 \pm 0.09 *$ & $12.65 \pm 0.11^{* *}$ & $13.03 \pm 0.08 * *$ & $13.35 \pm 0.15^{* *}$ & $13.35 \pm 0.12^{\dagger \dagger}$ \\
\hline \multicolumn{7}{|l|}{ Reticulocytes (\%) } \\
\hline $2.810 \pm 0.104$ & $3.03 \pm 0.19$ & $3.30 \pm 0.16$ & $3.50 \pm 0.12$ & $3.10 \pm 0.16$ & $3.51 \pm 0.30$ & $3.01 \pm 0.16$ \\
\hline \multicolumn{7}{|l|}{ Reticulocytes $\left(10^{3} / \mu \mathrm{L}\right)$} \\
\hline $295 \pm 20$ & $303 \pm 19$ & $326 \pm 15$ & $354 \pm 11$ & $315 \pm 18$ & $332 \pm 28$ & $270 \pm 17$ \\
\hline \multicolumn{7}{|c|}{ Nucleated erythrocytes (/100 leukocytes) } \\
\hline $0.0 \pm 0.0$ & $0.0 \pm 0.0$ & $0.0 \pm 0.0$ & $0.0 \pm 0.0$ & $0.0 \pm 0.0$ & $0.0 \pm 0.0$ & $0.0 \pm 0.0$ \\
\hline \multicolumn{7}{|l|}{ Mean cell volume (fL) } \\
\hline $48.6 \pm 0.2$ & $48.5 \pm 0.3$ & $48.2 \pm 0.3$ & $49.0 \pm 0.3$ & $48.6 \pm 0.3$ & $48.9 \pm 0.4$ & $48.9 \pm 0.2$ \\
\hline \multicolumn{7}{|l|}{ Mean cell hemoglobin (pg) } \\
\hline $15.9 \pm 0.0$ & $15.9 \pm 0.1$ & $16.0 \pm 0.1$ & $16.1 \pm 0.1$ & $16.0 \pm 0.0$ & $16.2 \pm 0.1$ & $16.4 \pm 0.1^{\dagger \dagger}$ \\
\hline \multicolumn{7}{|c|}{ Mean cell hemoglobin concentration (g/dL) } \\
\hline $32.9 \pm 0.1$ & $32.7 \pm 0.2$ & $33.1 \pm 0.1$ & $32.8 \pm 0.1$ & $33.0 \pm 0.1$ & $33.2 \pm 0.2 *$ & $33.5 \pm 0.1^{\dagger \dagger}$ \\
\hline \multicolumn{7}{|l|}{ Platelets $\left(10^{3} / \mu \mathrm{L}\right)$} \\
\hline $528 \pm 37$ & $577 \pm 39$ & $595 \pm 26$ & $608 \pm 29$ & $641 \pm 28$ & $699 \pm 34^{*}$ & $818 \pm 30^{\dagger \dagger}$ \\
\hline \multicolumn{7}{|l|}{ Mean platelet volume (fL) } \\
\hline $5.910 \pm 0.095$ & $5.860 \pm 0.180$ & $5.740 \pm 0.079$ & $5.870 \pm 0.116$ & $5.680 \pm 0.053$ & $5.620 \pm 0.051$ & $5.840 \pm 0.078$ \\
\hline \multicolumn{7}{|l|}{ Leukocytes $\left(10^{3} / \mu \mathrm{L}\right)$} \\
\hline $5.79 \pm 0.46$ & $6.17 \pm 0.29$ & $6.83 \pm 0.26$ & $6.25 \pm 0.40$ & $6.97 \pm 0.61$ & $6.98 \pm 0.63$ & $6.61 \pm 0.50$ \\
\hline \multicolumn{7}{|l|}{ Segmented neutrophils $\left(10^{3} / \mu \mathrm{L}\right)$} \\
\hline $1.28 \pm 0.11$ & $1.41 \pm 0.09$ & $1.64 \pm 0.06$ & $1.44 \pm 0.13$ & $1.54 \pm 0.16$ & $1.63 \pm 0.13$ & $1.68 \pm 0.17$ \\
\hline \multicolumn{7}{|l|}{ Bands $\left(10^{3} / \mu \mathrm{L}\right)$} \\
\hline $0.00 \pm 0.00$ & $0.00 \pm 0.00$ & $0.00 \pm 0.00$ & $0.00 \pm 0.00$ & $0.00 \pm 0.00$ & $0.00 \pm 0.00$ & $0.00 \pm 0.00$ \\
\hline
\end{tabular}


OTNE, NTP TOX 92

\begin{tabular}{|c|c|c|c|c|c|c|}
\hline $\begin{array}{c}\text { Untreated } \\
\text { Control }\end{array}$ & $\begin{array}{l}\text { Vehicle } \\
\text { Control }\end{array}$ & $6.25 \%$ & $12.5 \%$ & $25 \%$ & $50 \%$ & $100 \%$ \\
\hline \multicolumn{7}{|l|}{ Metamyelocytes $\left(10^{3} / \mu \mathrm{L}\right)$} \\
\hline $0.000 \pm 0.000$ & $0.000 \pm 0.000$ & $0.000 \pm 0.000$ & $0.000 \pm 0.000$ & $0.000 \pm 0.000$ & $0.000 \pm 0.000$ & $0.000 \pm 0.000$ \\
\hline \multicolumn{7}{|l|}{ Myelocytes $\left(10^{3} / \mu \mathrm{L}\right)$} \\
\hline $0.000 \pm 0.000$ & $0.000 \pm 0.000$ & $0.000 \pm 0.000$ & $0.000 \pm 0.000$ & $0.000 \pm 0.000$ & $0.000 \pm 0.000$ & $0.000 \pm 0.000$ \\
\hline \multicolumn{7}{|l|}{ Lymphocytes $\left(10^{3} / \mu \mathrm{L}\right)$} \\
\hline $4.44 \pm 0.36$ & $4.68 \pm 0.20$ & $5.11 \pm 0.22$ & $4.71 \pm 0.28$ & $5.34 \pm 0.45$ & $5.25 \pm 0.50$ & $4.80 \pm 0.37$ \\
\hline \multicolumn{7}{|l|}{ Atypical lymphocytes $\left(10^{3} / \mu \mathrm{L}\right)$} \\
\hline $0.00 \pm 0.00$ & $0.00 \pm 0.00$ & $0.00 \pm 0.00$ & $0.00 \pm 0.00$ & $0.00 \pm 0.00$ & $0.00 \pm 0.00$ & $0.00 \pm 0.00$ \\
\hline \multicolumn{7}{|l|}{ Monocytes $\left(10^{3} / \mu \mathrm{L}\right)$} \\
\hline $0.04 \pm 0.00$ & $0.04 \pm 0.01$ & $0.06 \pm 0.00$ & $0.06 \pm 0.01$ & $0.06 \pm 0.01$ & $0.07 \pm 0.01 * *$ & $0.09 \pm 0.01^{\dagger \dagger}$ \\
\hline \multicolumn{7}{|l|}{ Basophils $\left(10^{3} / \mu \mathrm{L}\right)$} \\
\hline $0.006 \pm 0.002$ & $0.011 \pm 0.003$ & $0.006 \pm 0.002$ & $0.014 \pm 0.005$ & $0.006 \pm 0.002$ & $0.009 \pm 0.002$ & $0.008 \pm 0.001$ \\
\hline
\end{tabular}

Eosinophils $\left(10^{3} / \mu \mathrm{L}\right)$

\begin{tabular}{lllllll}
$0.02 \pm 0.00$ & $0.03 \pm 0.01$ & $0.02 \pm 0.00$ & $0.03 \pm 0.01$ & $0.02 \pm 0.00$ & $0.02 \pm 0.01$ & $0.03 \pm 0.00$ \\
\hline
\end{tabular}

*Significantly different $(\mathrm{P} \leq 0.05)$ from the vehicle control group by Dunn's or Shirley's test.

$* * \mathrm{P} \leq 0.01$.

†Significantly different $(\mathrm{P} \leq 0.05)$ from the untreated control group by Wilcoxon’s rank sum test.

${ }^{\dagger} \mathrm{P} \leq 0.01$.

${ }^{\text {aData }}$ are presented as mean \pm standard error. Statistical tests were performed on unrounded data. Statistical comparisons between the two control groups are not presented.

Table B-4. CYP2E1 Activity in the Liver of Mice in the Three-month Dermal Study of OTNE ${ }^{\mathrm{a}}$

\begin{tabular}{|c|c|c|c|c|c|c|c|}
\hline & $\begin{array}{c}\text { Untreated } \\
\text { Control }\end{array}$ & $\begin{array}{l}\text { Vehicle } \\
\text { Control }\end{array}$ & $6.25 \%$ & $12.5 \%$ & $25 \%$ & $\mathbf{5 0 \%}$ & $100 \%$ \\
\hline $\mathbf{n}$ & 4 & 5 & 5 & 3 & 5 & 5 & 5 \\
\hline \multicolumn{8}{|c|}{ Male } \\
\hline \multicolumn{8}{|c|}{ CYP2E1 liver activity (nmol/minute per mg protein) } \\
\hline & $1.940 \pm 0.131$ & $1.883 \pm 0.185^{\mathrm{b}}$ & $2.193 \pm 0.098^{c}$ & $2.063 \pm 0.182$ & $2.542 \pm 0.177 *$ & $2.940 \pm 0.100 * *$ & $3.482 \pm 0.084^{\dagger \dagger}$ \\
\hline
\end{tabular}

\section{Female}

CYP2E1 liver activity (nmol/minute per mg protein)

$$
1.855 \pm 0.146 \quad 1.782 \pm 0.127 \quad 2.250 \pm 0.086 * 2.677 \pm 0.090 * * 2.742 \pm 0.068 * * 2.940 \pm 0.149 * * b \quad 2.780 \pm 0.177^{\dagger \dagger}
$$

*Significantly different $(\mathrm{P} \leq 0.05)$ from the vehicle control group by Shirley’s test.

$* * \mathrm{P} \leq 0.01$.

${ }^{\dagger}$ Significantly different $(\mathrm{P} \leq 0.01)$ from the untreated control group by Wilcoxon's rank sum test.

${ }^{\text {a } D a t a}$ are presented as mean \pm standard error. Statistical comparisons between the two control groups are not presented.

${ }^{b} \mathrm{n}=4$.

$c_{n}=3$. 


\section{Appendix C. Organ Weights and Organ-Weight-to-Body- Weight Ratios}

\section{Tables}

Table C-1. Organ Weights and Organ-Weight-to-Body-Weight Ratios for Rats in the Three-month Dermal Study of OTNE.

Table C-2. Organ Weights and Organ-Weight-to-Body-Weight Ratios for Mice in the Three-month Dermal Study of OTNE. 
OTNE, NTP TOX 92

Table C-1. Organ Weights and Organ-Weight-to-Body-Weight Ratios for Rats in the Three-month Dermal Study of OTNE

\begin{tabular}{|c|c|c|c|c|c|c|c|}
\hline & $\begin{array}{c}\text { Untreated } \\
\text { Control }\end{array}$ & $\begin{array}{l}\text { Vehicle } \\
\text { Control }\end{array}$ & $6.25 \%$ & $12.5 \%$ & $25 \%$ & $50 \%$ & $100 \%$ \\
\hline n & 10 & 10 & 10 & 10 & 10 & 10 & 10 \\
\hline \multicolumn{8}{|l|}{ Male } \\
\hline $\begin{array}{l}\text { Necropsy } \\
\text { body wt }\end{array}$ & $324 \pm 6$ & $318 \pm 6$ & $308 \pm 9$ & $293 \pm 5$ & $307 \pm 8$ & $302 \pm 7$ & $306 \pm 7$ \\
\hline \multicolumn{8}{|l|}{ Heart } \\
\hline Absolute & $1.02 \pm 0.02$ & $1.02 \pm 0.02$ & $0.93 \pm 0.01 *$ & $0.94 \pm 0.03$ & $0.99 \pm 0.03$ & $0.98 \pm 0.03$ & $0.98 \pm 0.02$ \\
\hline Relative & $3.16 \pm 0.04$ & $3.22 \pm 0.03$ & $3.04 \pm 0.06$ & $3.21 \pm 0.07$ & $3.23 \pm 0.09$ & $3.26 \pm 0.06$ & $3.19 \pm 0.05$ \\
\hline \multicolumn{8}{|l|}{ R. Kidney } \\
\hline Absolute & $1.19 \pm 0.03$ & $1.20 \pm 0.02$ & $1.14 \pm 0.03$ & $1.11 \pm 0.02$ & $1.14 \pm 0.03$ & $1.18 \pm 0.03$ & $1.24 \pm 0.03$ \\
\hline Relative & $3.66 \pm 0.05$ & $3.77 \pm 0.06$ & $3.71 \pm 0.06$ & $3.80 \pm 0.04$ & $3.71 \pm 0.06$ & $3.92 \pm 0.07$ & $4.04 \pm 0.05^{\dagger \dagger}$ \\
\hline \multicolumn{8}{|l|}{ Liver } \\
\hline Absolute & $13.62 \pm 0.54$ & $13.60 \pm 0.48$ & $12.81 \pm 0.44$ & $12.73 \pm 0.50$ & $13.33 \pm 0.46$ & $14.57 \pm 0.74$ & $15.93 \pm 0.65^{\dagger}$ \\
\hline Relative & $41.95 \pm 1.17$ & $42.77 \pm 1.16$ & $41.62 \pm 0.95$ & $43.55 \pm 1.84$ & $43.48 \pm 1.38$ & $48.04 \pm 1.64 *$ & $52.12 \pm 1.83^{\dagger \dagger}$ \\
\hline \multicolumn{8}{|l|}{ Lung } \\
\hline Absolute & $1.78 \pm 0.11$ & $1.72 \pm 0.07$ & $1.67 \pm 0.10$ & $1.60 \pm 0.05$ & $1.70 \pm 0.08$ & $1.57 \pm 0.05$ & $1.60 \pm 0.05$ \\
\hline Relative & $5.47 \pm 0.27$ & $5.40 \pm 0.19$ & $5.39 \pm 0.21$ & $5.49 \pm 0.22$ & $5.52 \pm 0.19$ & $5.19 \pm 0.11$ & $5.29 \pm 0.16$ \\
\hline \multicolumn{8}{|l|}{ R. Testis } \\
\hline Absolute & $1.543 \pm 0.102$ & $1.453 \pm 0.020$ & $1.427 \pm 0.035$ & $1.409 \pm 0.024$ & $1.478 \pm 0.029$ & $1.452 \pm 0.032$ & $1.467 \pm 0.025$ \\
\hline Relative & $4.762 \pm 0.301$ & $4.580 \pm 0.047$ & $4.645 \pm 0.081$ & $4.816 \pm 0.083$ & $4.824 \pm 0.079$ & $4.831 \pm 0.141$ & $4.806 \pm 0.058$ \\
\hline \multicolumn{8}{|l|}{ Thymus } \\
\hline Absolute & $0.347 \pm 0.056$ & $0.302 \pm 0.033$ & $0.394 \pm 0.075$ & $0.271 \pm 0.015$ & $0.274 \pm 0.015$ & $0.303 \pm 0.026$ & $0.359 \pm 0.074$ \\
\hline Relative & $1.068 \pm 0.172$ & $0.943 \pm 0.094$ & $1.280 \pm 0.248$ & $0.921 \pm 0.044$ & $0.896 \pm 0.052$ & $0.990 \pm 0.065$ & $1.155 \pm 0.224$ \\
\hline \multicolumn{8}{|l|}{ Female } \\
\hline $\begin{array}{l}\text { Necropsy } \\
\text { body wt }\end{array}$ & $184 \pm 4$ & $187 \pm 3$ & $188 \pm 2$ & $184 \pm 4$ & $187 \pm 4$ & $184 \pm 3$ & $180 \pm 3$ \\
\hline \multicolumn{8}{|l|}{ Heart } \\
\hline Absolute & $0.71 \pm 0.03$ & $0.73 \pm 0.01$ & $0.72 \pm 0.01$ & $0.71 \pm 0.02$ & $0.74 \pm 0.02$ & $0.73 \pm 0.01$ & $0.73 \pm 0.02$ \\
\hline Relative & $3.86 \pm 0.12$ & $3.91 \pm 0.04$ & $3.83 \pm 0.05$ & $3.87 \pm 0.09$ & $3.97 \pm 0.11$ & $3.95 \pm 0.08$ & $4.06 \pm 0.07$ \\
\hline \multicolumn{8}{|l|}{ R. Kidney } \\
\hline Absolute & $0.74 \pm 0.02$ & $0.78 \pm 0.02$ & $0.78 \pm 0.02$ & $0.77 \pm 0.02$ & $0.78 \pm 0.02$ & $0.80 \pm 0.01$ & $0.78 \pm 0.02$ \\
\hline Relative & $4.00 \pm 0.06$ & $4.18 \pm 0.08$ & $4.13 \pm 0.07$ & $4.18 \pm 0.07$ & $4.18 \pm 0.09$ & $4.32 \pm 0.03$ & $4.34 \pm 0.07^{\dagger \dagger}$ \\
\hline \multicolumn{8}{|l|}{ Liver } \\
\hline Absolute & $6.50 \pm 0.33$ & $6.99 \pm 0.21$ & $6.89 \pm 0.19$ & $7.09 \pm 0.27$ & $7.51 \pm 0.20$ & $7.78 \pm 0.27 * \mathrm{~b}$ & $8.24 \pm 0.18^{\dagger \dagger}$ \\
\hline Relative & $35.29 \pm 1.42$ & $37.44 \pm 0.67$ & $36.60 \pm 0.92$ & $38.52 \pm 1.40$ & $40.09 \pm 0.65$ & $41.93 \pm 1.35^{* * \mathrm{~b}}$ & $46.29 \pm 1.02^{\dagger \dagger}$ \\
\hline \multicolumn{8}{|l|}{ Lung } \\
\hline Absolute & $1.14 \pm 0.04$ & $1.13 \pm 0.04$ & $1.11 \pm 0.04$ & $1.26 \pm 0.11$ & $1.21 \pm 0.06$ & $1.13 \pm 0.04$ & $1.12 \pm 0.06$ \\
\hline Relative & $6.20 \pm 0.20$ & $6.07 \pm 0.27$ & $5.89 \pm 0.18$ & $6.77 \pm 0.50$ & $6.44 \pm 0.27$ & $6.14 \pm 0.25$ & $6.20 \pm 0.34$ \\
\hline
\end{tabular}


OTNE, NTP TOX 92

\begin{tabular}{cccccccc}
\hline & $\begin{array}{c}\text { Untreated } \\
\text { Control }\end{array}$ & $\begin{array}{c}\text { Vehicle } \\
\text { Control }\end{array}$ & $\mathbf{6 . 2 5 \%}$ & $\mathbf{1 2 . 5 \%}$ & $\mathbf{2 5 \%}$ & $\mathbf{5 0 \%}$ & $\mathbf{1 0 0 \%}$ \\
\hline Thymus & & & & & & & \\
Absolute & $0.292 \pm 0.017$ & $0.252 \pm 0.020$ & $0.249 \pm 0.020$ & $0.252 \pm 0.017$ & $0.252 \pm 0.013$ & $0.265 \pm 0.016$ & $0.255 \pm 0.008$ \\
Relative & $1.598 \pm 0.105$ & $1.343 \pm 0.095$ & $1.320 \pm 0.098$ & $1.361 \pm 0.084$ & $1.347 \pm 0.063$ & $1.442 \pm 0.094$ & $1.421 \pm 0.047$ \\
\hline
\end{tabular}

*Significantly different $(\mathrm{P} \leq 0.05)$ from the vehicle control group by Dunnett's or Williams' test.

$* * \mathrm{P} \leq 0.01$.

$\dagger$ Significantly different $(\mathrm{P} \leq 0.05)$ from the untreated control group by a $t$-test.

$\dagger \dagger \mathrm{P} \leq 0.01$.

${ }^{\mathrm{a} O r g a n}$ weights (absolute weights) and body weights are given in grams; organ-weight-to-body-weight ratios (relative weights) are given as mg organ weight/g body weight (mean \pm standard error). Statistical comparisons between the two control groups are not presented.

$\mathrm{b}_{\mathrm{n}}=9$. 
OTNE, NTP TOX 92

Table C-2. Organ Weights and Organ-Weight-to-Body-Weight Ratios for Mice in the Three-month Dermal Study of OTNE ${ }^{a}$

\begin{tabular}{|c|c|c|c|c|c|c|c|}
\hline & $\begin{array}{c}\text { Untreated } \\
\text { Control }\end{array}$ & $\begin{array}{l}\text { Vehicle } \\
\text { Control }\end{array}$ & $6.25 \%$ & $12.5 \%$ & $25 \%$ & $50 \%$ & $100 \%$ \\
\hline $\mathbf{n}$ & 10 & 10 & 10 & 10 & 10 & 10 & 10 \\
\hline \multicolumn{8}{|l|}{ Male } \\
\hline $\begin{array}{l}\text { Necropsy } \\
\text { body wt }\end{array}$ & $37.7 \pm 1.2$ & $35.0 \pm 0.6$ & $32.2 \pm 0.4 * *$ & $33.7 \pm 1.0$ & $32.0 \pm 0.4^{* *}$ & $32.5 \pm 0.5^{*}$ & $32.2 \pm 0.4^{\dagger \dagger}$ \\
\hline \multicolumn{8}{|l|}{ Heart } \\
\hline Absolute & $0.19 \pm 0.01$ & $0.18 \pm 0.00$ & $0.17 \pm 0.00$ & $0.17 \pm 0.01$ & $0.18 \pm 0.01$ & $0.18 \pm 0.01$ & $0.19 \pm 0.00$ \\
\hline Relative & $5.06 \pm 0.21$ & $4.99 \pm 0.09$ & $5.27 \pm 0.16$ & $5.16 \pm 0.14$ & $5.71 \pm 0.17 *$ & $5.46 \pm 0.24$ & $5.74 \pm 0.10^{\dagger}$ \\
\hline \multicolumn{8}{|l|}{ R. Kidney } \\
\hline Absolute & $0.35 \pm 0.02$ & $0.35 \pm 0.01$ & $0.32 \pm 0.01$ & $0.34 \pm 0.01$ & $0.34 \pm 0.01$ & $0.33 \pm 0.01$ & $0.33 \pm 0.02$ \\
\hline Relative & $9.24 \pm 0.40$ & $10.00 \pm 0.21$ & $9.98 \pm 0.20$ & $10.27 \pm 0.22$ & $10.54 \pm 0.34$ & $10.09 \pm 0.18$ & $10.20 \pm 0.63$ \\
\hline \multicolumn{8}{|l|}{ Liver } \\
\hline Absolute & $1.64 \pm 0.05$ & $1.60 \pm 0.05$ & $1.68 \pm 0.07$ & $1.82 \pm 0.09 *$ & $1.99 \pm 0.09 * *$ & $2.12 \pm 0.03 * *$ & $2.66 \pm 0.07^{\dagger \dagger}$ \\
\hline Relative & $43.79 \pm 1.34$ & $45.72 \pm 1.29$ & $51.98 \pm 1.96^{*}$ & $54.09 \pm 2.20 * *$ & $62.10 \pm 2.99 * *$ & $65.35 \pm 1.52 * *$ & $82.51 \pm 1.92^{\dagger \dagger}$ \\
\hline \multicolumn{8}{|l|}{ Lung } \\
\hline Absolute & $0.29 \pm 0.02$ & $0.30 \pm 0.02$ & $0.29 \pm 0.02$ & $0.31 \pm 0.02$ & $0.27 \pm 0.02$ & $0.26 \pm 0.02$ & $0.27 \pm 0.02$ \\
\hline Relative & $7.69 \pm 0.38$ & $8.49 \pm 0.51$ & $8.98 \pm 0.59$ & $9.34 \pm 0.60$ & $8.45 \pm 0.63$ & $8.12 \pm 0.48$ & $8.44 \pm 0.50$ \\
\hline \multicolumn{8}{|l|}{ R. Testis } \\
\hline Absolute & $0.127 \pm 0.004$ & $0.128 \pm 0.002$ & $0.120 \pm 0.005$ & $0.127 \pm 0.004$ & $0.120 \pm 0.002$ & $0.115 \pm 0.004 *$ & $0.119 \pm 0.004$ \\
\hline Relative & $3.397 \pm 0.131$ & $3.661 \pm 0.086$ & $3.734 \pm 0.156$ & $3.780 \pm 0.103$ & $3.760 \pm 0.072$ & $3.544 \pm 0.078$ & $3.693 \pm 0.121$ \\
\hline \multicolumn{8}{|l|}{ Thymus } \\
\hline Absolute & $0.050 \pm 0.003$ & $0.050 \pm 0.003$ & $0.043 \pm 0.002$ & $0.042 \pm 0.004$ & $0.041 \pm 0.003$ & $0.041 \pm 0.002$ & $0.039 \pm 0.003^{\dagger}$ \\
\hline Relative & $1.338 \pm 0.082$ & $1.424 \pm 0.098$ & $1.346 \pm 0.073$ & $1.233 \pm 0.078$ & $1.268 \pm 0.082$ & $1.273 \pm 0.075$ & $1.202 \pm 0.078$ \\
\hline \multicolumn{8}{|l|}{ Female } \\
\hline $\begin{array}{l}\text { Necropsy } \\
\text { body wt }\end{array}$ & $28.5 \pm 0.7$ & $29.5 \pm 0.7$ & $30.1 \pm 0.7$ & $29.2 \pm 0.6$ & $28.9 \pm 0.3$ & $29.2 \pm 0.4$ & $29.4 \pm 0.3$ \\
\hline \multicolumn{8}{|l|}{ Heart } \\
\hline Absolute & $0.14 \pm 0.00$ & $0.15 \pm 0.01$ & $0.15 \pm 0.00$ & $0.16 \pm 0.01$ & $0.16 \pm 0.00$ & $0.17 \pm 0.00 *$ & $0.16 \pm 0.01^{\dagger \dagger}$ \\
\hline Relative & $4.85 \pm 0.08$ & $5.08 \pm 0.18$ & $5.12 \pm 0.13$ & $5.36 \pm 0.20$ & $5.47 \pm 0.09$ & $5.68 \pm 0.16^{*}$ & $5.55 \pm 0.16^{\dagger \dagger}$ \\
\hline \multicolumn{8}{|l|}{ R. Kidney } \\
\hline Absolute & $0.21 \pm 0.01$ & $0.22 \pm 0.01$ & $0.21 \pm 0.00$ & $0.23 \pm 0.01$ & $0.22 \pm 0.01$ & $0.24 \pm 0.01$ & $0.23 \pm 0.01$ \\
\hline Relative & $7.51 \pm 0.20$ & $7.39 \pm 0.21$ & $7.13 \pm 0.19$ & $8.00 \pm 0.32$ & $7.57 \pm 0.23$ & $8.11 \pm 0.23$ & $7.84 \pm 0.21$ \\
\hline \multicolumn{8}{|l|}{ Liver } \\
\hline Absolute & $1.28 \pm 0.04$ & $1.37 \pm 0.05$ & $1.52 \pm 0.04^{*}$ & $1.65 \pm 0.04 * *$ & $1.69 \pm 0.03^{* *}$ & $2.04 \pm 0.05 * *$ & $2.46 \pm 0.07^{\dagger \dagger}$ \\
\hline Relative & $45.04 \pm 1.03$ & $46.48 \pm 1.46$ & $50.45 \pm 0.76^{*}$ & $56.53 \pm 1.22 * *$ & $58.35 \pm 0.61 * *$ & $69.96 \pm 1.26^{* *}$ & $83.54 \pm 2.31^{\dagger \dagger}$ \\
\hline \multicolumn{8}{|l|}{ Lung } \\
\hline Absolute & $0.30 \pm 0.02$ & $0.29 \pm 0.02$ & $0.26 \pm 0.01$ & $0.32 \pm 0.02$ & $0.27 \pm 0.03$ & $0.26 \pm 0.02$ & $0.24 \pm 0.02$ \\
\hline Relative & $10.41 \pm 0.74$ & $9.86 \pm 0.75$ & $8.71 \pm 0.52$ & $10.91 \pm 0.76$ & $9.44 \pm 0.85$ & $8.91 \pm 0.54$ & $8.22 \pm 0.69^{\dagger}$ \\
\hline
\end{tabular}


OTNE, NTP TOX 92

\begin{tabular}{lccccccc}
\hline & $\begin{array}{c}\text { Untreated } \\
\text { Control }\end{array}$ & $\begin{array}{c}\text { Vehicle } \\
\text { Control }\end{array}$ & $\mathbf{6 . 2 5 \%}$ & $\mathbf{1 2 . 5 \%}$ & $\mathbf{2 5 \%}$ & $\mathbf{5 0 \%}$ & $\mathbf{1 0 0 \%}$ \\
\hline Thymus & & & & & & & \\
Absolute & $0.056 \pm 0.002$ & $0.058 \pm 0.003$ & $0.057 \pm 0.002$ & $0.053 \pm 0.003$ & $0.049 \pm 0.004$ & $0.052 \pm 0.002$ & $0.046 \pm 0.002^{\dagger \dagger}$ \\
Relative & $1.982 \pm 0.056$ & $1.966 \pm 0.102$ & $1.924 \pm 0.095$ & $1.815 \pm 0.075$ & $1.706 \pm 0.137$ & $1.766 \pm 0.078$ & $1.548 \pm 0.090^{\dagger \dagger}$ \\
\hline
\end{tabular}

*Significantly different $(\mathrm{P} \leq 0.05)$ from the vehicle control group by Dunnett's or Williams' test.

$* * \mathrm{P} \leq 0.01$.

${ }^{\dagger}$ Significantly different $(\mathrm{P} \leq 0.05)$ from the untreated control group by a $t$-test.

${ }^{\dagger} \mathrm{P} \leq 0.01$.

${ }^{\mathrm{a}}$ Organ weights (absolute weights) and body weights are given in grams; organ-weight-to-body-weight ratios (relative weights) are given as mg organ weight/g body weight (mean \pm standard error). Statistical comparisons between the two control groups are not presented. 
OTNE, TOX 92

\section{Appendix D. Reproductive Tissue Evaluations and Estrous Cycle Characterization}

\section{Tables}

Table D-1. Summary of Reproductive Tissue Evaluations for Male Rats in the Threemonth Dermal Study of OTNE

Table D-2. Estrous Cycle Characterization for Female Rats in the Three-month Dermal Study of OTNE.................................................................................... D-3

Table D-3. Summary of Reproductive Tissue Evaluations for Male Mice in the Threemonth Dermal Study of OTNE . D-4

Table D-4. Estrous Cycle Characterization for Female Mice in the Three-month Dermal

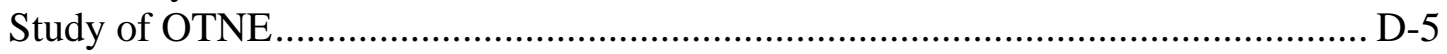


OTNE, TOX 92

Table D-1. Summary of Reproductive Tissue Evaluations for Male Rats in the Three-month Dermal Study of OTNE ${ }^{a}$

\begin{tabular}{|c|c|c|c|c|c|}
\hline & $\begin{array}{l}\text { Untreated } \\
\text { Control }\end{array}$ & Vehicle Control & $25 \%$ & $\mathbf{5 0 \%}$ & $100 \%$ \\
\hline $\mathbf{n}$ & 10 & 10 & 10 & 10 & 10 \\
\hline \multicolumn{6}{|l|}{ Weights (g) } \\
\hline Necropsy body wt & $325 \pm 6$ & $318 \pm 6$ & $307 \pm 8$ & $302 \pm 7$ & $306 \pm 7$ \\
\hline L. Cauda epididymis & $0.1850 \pm 0.0051$ & $0.1884 \pm 0.0066$ & $0.1782 \pm 0.0051$ & $0.1736 \pm 0.0087$ & $0.1809 \pm 0.0072$ \\
\hline L. Epididymis & $0.4790 \pm 0.0190$ & $0.4457 \pm 0.0145$ & $0.4608 \pm 0.0100$ & $0.4580 \pm 0.0202$ & $0.4507 \pm 0.0141$ \\
\hline L. Testis & $1.5291 \pm 0.0222$ & $1.4998 \pm 0.0315$ & $1.5005 \pm 0.0233$ & $1.5015 \pm 0.0340$ & $1.5300 \pm 0.0360$ \\
\hline \multicolumn{6}{|l|}{ Spermatid measurements } \\
\hline $\begin{array}{l}\text { Spermatid heads } \\
\left(10^{6} / \mathrm{g} \text { testis }\right)\end{array}$ & $105.01 \pm 5.31$ & $129.89 \pm 7.50$ & $118.07 \pm 10.87$ & $122.10 \pm 13.34$ & $108.85 \pm 6.97$ \\
\hline $\begin{array}{l}\text { Spermatid heads } \\
\left(10^{6} / \text { testis }\right)\end{array}$ & $160.52 \pm 8.41$ & $194.42 \pm 11.31$ & $177.51 \pm 16.75$ & $182.77 \pm 19.24$ & $167.21 \pm 12.74$ \\
\hline \multicolumn{6}{|c|}{ Epididymal spermatozoal measurements } \\
\hline Sperm motility $(\%)$ & $85.2 \pm 3.4$ & $80.5 \pm 5.8$ & $89.4 \pm 2.1$ & $87.5 \pm 2.4$ & $74.8 \pm 9.0$ \\
\hline $\begin{array}{l}\text { Sperm }\left(10^{6} / g \text { cauda }\right. \\
\text { epididymis })\end{array}$ & $335.6 \pm 14.4$ & $326.8 \pm 45.2$ & $349.5 \pm 20.2$ & $321.7 \pm 36.2$ & $371.3 \pm 30.7$ \\
\hline $\begin{array}{l}\text { Sperm }\left(10^{6} / \text { cauda }\right. \\
\text { epididymis })\end{array}$ & $62.1 \pm 3.4$ & $61.1 \pm 8.3$ & $61.8 \pm 2.9$ & $58.0 \pm 7.0$ & $66.2 \pm 5.1$ \\
\hline
\end{tabular}


OTNE, TOX 92

Table D-2. Estrous Cycle Characterization for Female Rats in the Three-month Dermal Study of OTNE $^{\mathrm{a}}$

\begin{tabular}{|c|c|c|c|c|c|}
\hline & $\begin{array}{l}\text { Untreated } \\
\text { Control }\end{array}$ & $\begin{array}{l}\text { Vehicle } \\
\text { Control }\end{array}$ & $25 \%$ & $50 \%$ & $100 \%$ \\
\hline Number weighed at necropsy & 10 & 10 & 10 & 10 & 10 \\
\hline Necropsy body wt (g) & $184 \pm 4$ & $187 \pm 3$ & $187 \pm 4$ & $184 \pm 3$ & $180 \pm 3$ \\
\hline $\begin{array}{l}\text { Proportion of regular } \\
\text { cycling females }^{\mathrm{b}}\end{array}$ & $10 / 10$ & $9 / 10$ & $10 / 10$ & $10 / 10$ & $10 / 10$ \\
\hline Estrous cycle length (days) & $5.0 \pm 0.1$ & $4.9 \pm 0.2$ & $4.8 \pm 0.1$ & $4.7 \pm 0.2$ & $4.9 \pm 0.1$ \\
\hline \multicolumn{6}{|l|}{ Estrous stages (\% of cycle) } \\
\hline Diestrus & 60.0 & 61.3 & 53.1 & 53.1 & 59.4 \\
\hline Proestrus & 11.9 & 8.8 & 10.6 & 15.0 & 13.8 \\
\hline Estrus & 26.3 & 25.6 & 30.6 & 24.4 & 23.1 \\
\hline Metestrus & 0.0 & 0.0 & 0.0 & 0.0 & 0.0 \\
\hline Uncertain diagnosis & 1.9 & 4.4 & 5.6 & 7.5 & 3.8 \\
\hline \multicolumn{6}{|c|}{$\begin{array}{l}\text { "Necropsy body weights and estrous cycle length data are presented as mean } \pm \text { standard error. Differences between the vehicle } \\
\text { control group and the } 25 \% \text { and } 50 \% \text { groups are not significant by Dunnett's test (body weights) or Dunn's test (estrous cycle } \\
\text { length). Differences between the untreated control group and the } 100 \% \text { group are not significant by a } t \text {-test (body weights) or } \\
\text { Dunn's test (estrous cycle length). By multivariate analysis of variance, dosed females do not differ significantly from the vehicle } \\
\text { control females in the relative length of time spent in the estrous stages. Tests for equality of transition probability matrices } \\
\text { among all groups and between the respective control group and each dosed group indicated treated females did not spend } \\
\text { significantly more time in a given estrous stage than did the respective control group. Statistical comparisons between the two } \\
\text { control groups are not presented. } \\
\text { bumber of females with a regular cycle/number of females cycling. }\end{array}$} \\
\hline
\end{tabular}


OTNE, TOX 92

Table D-3. Summary of Reproductive Tissue Evaluations for Male Mice in the Three-month Dermal Study of OTNE

\begin{tabular}{|c|c|c|c|c|c|}
\hline & $\begin{array}{l}\text { Untreated } \\
\text { Control }\end{array}$ & Vehicle Control & $25 \%$ & $\mathbf{5 0 \%}$ & $100 \%$ \\
\hline $\mathbf{n}$ & 9 & 10 & 7 & 7 & 10 \\
\hline \multicolumn{6}{|l|}{ Weights (g) } \\
\hline Necropsy body wt & $37.8 \pm 1.3$ & $35.0 \pm 0.6$ & $32.2 \pm 0.5 * *$ & $32.9 \pm 0.5^{*}$ & $32.2 \pm 0.4^{\dagger \dagger}$ \\
\hline L. Cauda epididymis & $0.0210 \pm 0.0015$ & $0.0196 \pm 0.0011$ & $0.0218 \pm 0.0017$ & $0.0252 \pm 0.0041$ & $0.0170 \pm 0.0012^{\dagger}$ \\
\hline L. Epididymis & $0.0515 \pm 0.0040$ & $0.0480 \pm 0.0023$ & $0.0615 \pm 0.0068$ & $0.0549 \pm 0.0040$ & $0.0435 \pm 0.0021$ \\
\hline L. Testis & $0.1119 \pm 0.0022$ & $0.1119 \pm 0.0016$ & $0.1114 \pm 0.0041$ & $0.1085 \pm 0.0038$ & $0.1052 \pm 0.0025$ \\
\hline \multicolumn{6}{|l|}{ Spermatid measurements } \\
\hline $\begin{array}{l}\text { Spermatid heads } \\
\left(10^{6} / \mathrm{g} \text { testis }\right)\end{array}$ & $214.10 \pm 17.77$ & $233.47 \pm 16.49$ & $252.91 \pm 18.67$ & $254.21 \pm 16.20$ & $234.12 \pm 21.35$ \\
\hline $\begin{array}{l}\text { Spermatid heads } \\
\left(10^{6} / \text { testis }\right)\end{array}$ & $23.93 \pm 1.97$ & $26.21 \pm 2.10$ & $27.93 \pm 1.79$ & $27.57 \pm 2.00$ & $24.80 \pm 2.40$ \\
\hline \multicolumn{6}{|c|}{ Epididymal spermatozoal measurements } \\
\hline Sperm motility (\%) & $90.8 \pm 2.2$ & $94.7 \pm 0.8$ & $91.0 \pm 3.6$ & $92.4 \pm 1.9$ & $80.6 \pm 7.4$ \\
\hline $\begin{array}{l}\text { Sperm }\left(10^{6} / \mathrm{g} \text { cauda }\right. \\
\text { epididymis })\end{array}$ & $169.9 \pm 21.6$ & $151.1 \pm 11.2$ & $144.3 \pm 8.9$ & $153.9 \pm 29.2$ & $112.2 \pm 22.4$ \\
\hline $\begin{array}{l}\text { Sperm }\left(10^{6} / \text { cauda }\right. \\
\text { epididymis })\end{array}$ & $3.4 \pm 0.3$ & $2.9 \pm 0.2$ & $3.2 \pm 0.4$ & $3.5 \pm 0.7$ & $1.8 \pm 0.3^{\dagger \dagger}$ \\
\hline
\end{tabular}

*Significantly different $(\mathrm{P} \leq 0.05)$ from the vehicle control group by Dunnett's test.

$* * \mathrm{P} \leq 0.01$.

†Significantly different $(\mathrm{P} \leq 0.05)$ from the untreated control group by Wilcoxon’s rank sum test.

${ }^{\dagger}$ Significantly different $(\mathrm{P} \leq 0.01)$ from the untreated control group by a $t$-test (body weights) or Wilcoxon's rank sum test (sperm/cauda epididymis).

${ }^{\text {a}}$ Data are presented as mean \pm standard error. Differences between the vehicle control group and the $25 \%$ and $50 \%$ groups are not significant by Dunnett's test (tissue weights) or Dunn's test (spermatid and epididymal spermatozoal measurements). Differences between the untreated control group and the $100 \%$ group are not significant by a $t$-test (tissue weights) or Wilcoxon's rank sum test (spermatid measurements, sperm motility, and sperm/g cauda epididymis). Statistical comparisons between the two control groups are not presented. 
OTNE, TOX 92

Table D-4. Estrous Cycle Characterization for Female Mice in the Three-month Dermal Study of OTNE $^{\mathrm{a}}$

\begin{tabular}{lccccc}
\hline & $\begin{array}{c}\text { Untreated } \\
\text { Control }\end{array}$ & $\begin{array}{c}\text { Vehicle } \\
\text { Control }\end{array}$ & $\mathbf{2 5 \%}$ & $\mathbf{5 0 \%}$ & $\mathbf{1 0 0 \%}$ \\
\hline Number weighed at necropsy & 10 & 10 & 10 & 10 & 10 \\
$\begin{array}{l}\text { Necropsy body wt (g) } \\
\begin{array}{l}\text { Proportion of regular } \\
\text { cycling females }\end{array}\end{array}$ & $28.5 \pm 0.7$ & $29.5 \pm 0.7$ & $28.9 \pm 0.3$ & $29.2 \pm 0.4$ & $29.4 \pm 0.3$ \\
$\begin{array}{l}\text { Estrous cycle length (days) } \\
\text { Estrous stages (\% of cycle) }\end{array}$ & $9 / 10$ & $10 / 10$ & $10 / 10$ & $10 / 10$ & $9 / 10$ \\
$\quad$ Diestrus & 38.0 & $4.5 \pm 0.2$ & $4.6 \pm 0.2$ & $4.5 \pm 0.2$ & $5.2 \pm 0.3^{\dagger \dagger}$ \\
Proestrus & 0.0 & 38.8 & 31.3 & 33.8 & 37.5 \\
Estrus & 38.1 & 43.1 & 1.3 & 0.6 & 0.0 \\
Metestrus & 15.0 & 11.9 & 10.0 & 6.3 & 53.1 \\
Uncertain diagnosis & 8.1 & 6.3 & 6.3 & 3.1 & 6.9 \\
\hline
\end{tabular}

${ }^{\dagger}$ Significantly different $(\mathrm{P} \leq 0.01)$ from the untreated control group by Dunn's test.

${ }^{a}$ Necropsy body weights and estrous cycle length data are presented as mean \pm standard error. Differences between the vehicle control group and the $25 \%$ and 50\% groups are not significant by Dunnett's test (body weights) or Dunn's test (estrous cycle length). Differences between the untreated control group and the $100 \%$ group are not significant by a $t$-test (body weights). By multivariate analysis of variance, dosed females do not differ significantly from the vehicle control females in the relative length of time spent in the estrous stages. Tests for equality of transition probability matrices among all groups and between the respective control group and each dosed group indicated the probability of extended estrus was significantly higher in the dosed groups than the respective control groups. Statistical comparisons between the two control groups are not presented.

${ }^{b}$ Number of females with a regular cycle/number of females cycling. 
OTNE, TOX 92

\section{Appendix E. Genetic Toxicology}

\section{Tables}

Table E-1. Mutagenicity of OTNE in Salmonella typhimurium

Table E-2. Mutagenicity of OTNE in Bacterial Tester Strains

Table E-3. Frequency of Micronuclei in Peripheral Blood Erythrocytes of Rats Following Dermal Application of OTNE for Three Months ....

Table E-4. Frequency of Micronuclei in Peripheral Blood Erythrocytes of Mice

Following Dermal Application of OTNE for Three Months 
OTNE, TOX 92

Table E-1. Mutagenicity of OTNE in Salmonella typhimurium ${ }^{\text {a }}$

\begin{tabular}{|c|c|c|c|}
\hline Strain & Dose ( $\mu g /$ plate) & Without S9 & With $10 \%$ Rat S9 \\
\hline \multirow[t]{6}{*}{ TA102 } & 0 & $293 \pm 6$ & $396 \pm 27$ \\
\hline & 100 & $349 \pm 11$ & $349 \pm 16$ \\
\hline & 333 & $373 \pm 14$ & $434 \pm 29$ \\
\hline & 1,000 & $382 \pm 18$ & $352 \pm 16$ \\
\hline & 3,333 & $352 \pm 4$ & $322 \pm 13$ \\
\hline & 10,000 & $362 \pm 20^{\mathrm{b}}$ & $320 \pm 9^{b}$ \\
\hline Trial summary & & Negative & Negative \\
\hline Positive control $^{c}$ & & $1,354 \pm 12$ & $1,495 \pm 44$ \\
\hline \multirow[t]{6}{*}{ TA100 } & 0 & $144 \pm 6$ & $152 \pm 12$ \\
\hline & 100 & $122 \pm 6$ & $153 \pm 10$ \\
\hline & 333 & $118 \pm 8$ & $129 \pm 8$ \\
\hline & 1,000 & $125 \pm 8$ & $115 \pm 7$ \\
\hline & 3,333 & $104 \pm 3^{b}$ & $94 \pm 1^{\mathrm{b}}$ \\
\hline & 10,000 & $117 \pm 2^{b}$ & $98 \pm 8^{b}$ \\
\hline Trial summary & & Negative & Negative \\
\hline Positive control & & $448 \pm 9$ & $917 \pm 36$ \\
\hline \multirow[t]{6}{*}{ TA98 } & 0 & $19 \pm 1$ & $29 \pm 0$ \\
\hline & 100 & $21 \pm 1$ & $34 \pm 5$ \\
\hline & 333 & $22 \pm 1$ & $21 \pm 3$ \\
\hline & 1,000 & $23 \pm 2$ & $29 \pm 1$ \\
\hline & 3,333 & $23 \pm 1^{b}$ & $23 \pm 3^{b}$ \\
\hline & 10,000 & $16 \pm 1^{\mathrm{b}}$ & $27 \pm 2^{\mathrm{b}}$ \\
\hline Trial summary & & Negative & Negative \\
\hline Positive control & & $137 \pm 21$ & $441 \pm 197$ \\
\hline
\end{tabular}


OTNE, TOX 92

Table E-2. Mutagenicity of OTNE in Bacterial Tester Strains ${ }^{\text {a }}$

\begin{tabular}{|c|c|c|c|c|c|}
\hline Strain & Dose ( $\mu \mathrm{g} / \mathrm{plate})$ & Without S9 & Without S9 & With $10 \%$ Rat S9 & With $10 \%$ Rat S9 \\
\hline \multicolumn{6}{|l|}{ TA100 } \\
\hline & 0 & $92 \pm 6$ & $90 \pm 1$ & $91 \pm 11$ & $103 \pm 6$ \\
\hline & 100 & $72 \pm 5$ & $50 \pm 1$ & $100 \pm 5$ & $111 \pm 6$ \\
\hline & 350 & $60 \pm 8$ & $54 \pm 3$ & $86 \pm 8$ & $73 \pm 5$ \\
\hline & 1,000 & $68 \pm 1$ & $57 \pm 4$ & $61 \pm 6$ & $51 \pm 6$ \\
\hline & 1,500 & $65 \pm 3$ & $56 \pm 7$ & $38 \pm 8^{b}$ & $52 \pm 4$ \\
\hline & 3,000 & $65 \pm 5$ & $51 \pm 1$ & $45 \pm 2^{\mathrm{b}}$ & $50 \pm 8$ \\
\hline & 6,000 & $58 \pm 3$ & $57 \pm 4$ & $26 \pm 5^{\mathrm{c}}$ & $26 \pm 3^{c}$ \\
\hline Trial summary & & Negative & Negative & Negative & Negative \\
\hline Positive control $^{\mathrm{d}}$ & & $782 \pm 23$ & $793 \pm 23$ & $506 \pm 14$ & $452 \pm 13$ \\
\hline \multicolumn{6}{|l|}{ TA98 } \\
\hline & 0 & $22 \pm 1$ & $16 \pm 1$ & $24 \pm 3$ & $30 \pm 4$ \\
\hline & 100 & $22 \pm 4$ & $15 \pm 2$ & $23 \pm 1$ & $29 \pm 5$ \\
\hline & 350 & $17 \pm 7$ & $20 \pm 1$ & $24 \pm 2$ & $25 \pm 3$ \\
\hline & 1,000 & $13 \pm 3$ & $14 \pm 2$ & $24 \pm 1$ & $25 \pm 2$ \\
\hline & 1,500 & $13 \pm 1$ & $17 \pm 2$ & $23 \pm 2$ & $28 \pm 4$ \\
\hline & 3,000 & $18 \pm 3$ & $23 \pm 2$ & $25 \pm 4$ & $23 \pm 4$ \\
\hline & 6,000 & $17 \pm 3$ & $22 \pm 3$ & $15 \pm 4^{\mathrm{e}}$ & $25 \pm 2^{\mathrm{e}}$ \\
\hline Trial summary & & Negative & Negative & Negative & Negative \\
\hline Positive control & & $528 \pm 30$ & $639 \pm 32$ & $1,395 \pm 26$ & $1,419 \pm 25$ \\
\hline \multicolumn{6}{|c|}{ Escherichia coli WP2 uvrA/pKM101 } \\
\hline & 0 & $155 \pm 5$ & $144 \pm 4$ & $222 \pm 13$ & $197 \pm 9$ \\
\hline & 100 & $148 \pm 4$ & $158 \pm 6$ & $222 \pm 4$ & $241 \pm 1$ \\
\hline & 350 & $171 \pm 5$ & $160 \pm 14$ & $190 \pm 9$ & $206 \pm 12$ \\
\hline & 1,000 & $146 \pm 5$ & $143 \pm 4$ & $170 \pm 11$ & $168 \pm 9$ \\
\hline & 1,500 & $141 \pm 8$ & $151 \pm 2$ & $160 \pm 6$ & $183 \pm 9$ \\
\hline & 3,000 & $142 \pm 11$ & $158 \pm 3$ & $148 \pm 5$ & $159 \pm 10$ \\
\hline & 6,000 & $158 \pm 10$ & $149 \pm 9$ & $146 \pm 13^{\mathrm{e}}$ & $157 \pm 18^{\mathrm{e}}$ \\
\hline Trial summary & & Negative & Negative & Negative & Negative \\
\hline Positive control & & $3,171 \pm 58$ & $3,090 \pm 59$ & $1,598 \pm 60$ & $1,685 \pm 63$ \\
\hline \multicolumn{6}{|c|}{$\begin{array}{l}\text { aStudy was performed at ILS, Inc., using lot RAV0276433. Data are presented as revertants/plate (mean } \pm \text { standard error) from } \\
\text { three plates. } 0 \mu \mathrm{g} / \mathrm{plate} \text { was the solvent control. } \\
\text { bSlight toxicity. } \\
\text { cSlight toxicity and precipitate on plate. } \\
\text { dThe positive controls in the absence of metabolic activation were sodium azide (TA100), 4-nitro-o-phenylenediamine (TA98), } \\
\text { and methyl methanesulfonate (E. coli). The positive control for metabolic activation with all strains was 2-aminoanthracene. } \\
\text { 'Precipitate on plate. }\end{array}$} \\
\hline
\end{tabular}


OTNE, TOX 92

Table E-3. Frequency of Micronuclei in Peripheral Blood Erythrocytes of Rats Following Dermal Application of OTNE for Three Months ${ }^{\mathrm{a}}$

\begin{tabular}{|c|c|c|c|c|c|c|c|c|}
\hline & $\begin{array}{c}\text { Dose } \\
(\%)\end{array}$ & $\begin{array}{l}\text { Number of } \\
\text { Rats with } \\
\text { Erythrocytes } \\
\text { Scored }\end{array}$ & $\begin{array}{l}\text { MicronucleatedP } \\
\text { CEs/1,000 PCEs }^{\mathrm{b}}\end{array}$ & $\begin{array}{c}\mathbf{P} \\
\text { Value }^{\mathrm{c}}\end{array}$ & $\begin{array}{c}\text { Micronucleated } \\
\text { NCEs/1,000 } \\
\text { NCEs }\end{array}$ & $\begin{array}{c}\mathbf{P} \\
\text { Value }^{\mathrm{d}}\end{array}$ & $\operatorname{PCEs}^{\mathrm{b}}(\%)$ & $\begin{array}{c}\mathbf{P} \\
\text { Value }^{\mathrm{d}}\end{array}$ \\
\hline \multicolumn{9}{|l|}{ Male } \\
\hline Vehicle control $^{\mathrm{e}}$ & 0 & 5 & $0.38 \pm 0.06$ & & $0.08 \pm 0.01$ & & $1.20 \pm 0.07$ & \\
\hline \multirow[t]{5}{*}{ OTNE } & 6.25 & 5 & $0.43 \pm 0.08$ & 0.431 & $0.07 \pm 0.01$ & 0.980 & $1.18 \pm 0.03$ & 1.000 \\
\hline & 12.5 & 5 & $0.36 \pm 0.03$ & 0.509 & $0.04 \pm 0.01$ & 0.993 & $1.23 \pm 0.03$ & 1.000 \\
\hline & 25 & 5 & $0.65 \pm 0.07$ & 0.021 & $0.05 \pm 0.00$ & 0.996 & $1.29 \pm 0.07$ & 1.000 \\
\hline & 50 & 5 & $0.50 \pm 0.06$ & 0.022 & $0.05 \pm 0.01$ & 0.997 & $1.00 \pm 0.08$ & 0.022 \\
\hline & & & $\mathrm{P}=0.045^{\mathrm{f}}$ & & $P=0.963^{f}$ & & $\mathrm{P}=0.025^{\mathrm{f}}$ & \\
\hline Untreated control & & 5 & $0.38 \pm 0.04$ & & $0.09 \pm 0.01$ & & $1.12 \pm 0.05$ & \\
\hline OTNE & 100 & 5 & $0.43 \pm 0.09$ & 0.320 & $0.04 \pm 0.01$ & 0.969 & $1.11 \pm 0.07$ & 0.850 \\
\hline Untreated control & & 5 & $0.38 \pm 0.04$ & & $0.09 \pm 0.01$ & & $1.12 \pm 0.05$ & \\
\hline Vehicle control & 0 & 5 & $0.38 \pm 0.06$ & 0.502 & $0.08 \pm 0.01$ & 0.621 & $1.20 \pm 0.07$ & 0.400 \\
\hline \multicolumn{9}{|l|}{ Female } \\
\hline Vehicle control & 0 & 5 & $0.58 \pm 0.15$ & & $0.08 \pm 0.03$ & & $0.79 \pm 0.07$ & \\
\hline \multirow[t]{5}{*}{ OTNE } & 6.25 & 5 & $0.40 \pm 0.06$ & 0.690 & $0.04 \pm 0.01$ & 1.000 & $0.84 \pm 0.12$ & 1.000 \\
\hline & 12.5 & 5 & $0.55 \pm 0.21$ & 0.653 & $0.06 \pm 0.02$ & 1.000 & $1.07 \pm 0.11$ & 0.375 \\
\hline & 25 & 5 & $0.58 \pm 0.06$ & 0.688 & $0.06 \pm 0.01$ & 1.000 & $0.69 \pm 0.04$ & 1.000 \\
\hline & 50 & 5 & $0.52 \pm 0.09$ & 0.707 & $0.03 \pm 0.00$ & 1.000 & $0.70 \pm 0.05$ & 1.000 \\
\hline & & & $P=0.454^{f}$ & & $\mathrm{P}=0.910^{\mathrm{g}}$ & & $\mathrm{P}=0.214^{\mathrm{g}}$ & \\
\hline Untreated control & & 5 & $0.53 \pm 0.07$ & & $0.07 \pm 0.02$ & & $0.96 \pm 0.06$ & \\
\hline OTNE & 100 & 5 & $0.45 \pm 0.05$ & 0.677 & $0.10 \pm 0.02$ & 0.116 & $1.29 \pm 0.34$ & 0.465 \\
\hline Untreated control & & 5 & $0.53 \pm 0.07$ & & $0.07 \pm 0.02$ & & $0.96 \pm 0.06$ & \\
\hline Vehicle control & 0 & 5 & $0.58 \pm 0.15$ & 0.385 & $0.08 \pm 0.03$ & 0.412 & $0.79 \pm 0.07$ & 0.112 \\
\hline $\begin{array}{l}\text { a'Study was perform } \\
\text { PCE = polychromat } \\
{ }^{b} \text { Mean } \pm \text { standard e } \\
{ }^{c} \text { Pairwise comparis } \\
\text { by Williams' test; } 1 \\
\text { values are significa } \\
\text { dPairwise comparis } \\
\text { and 50\% males) or } \\
\text { vehicle control grou } \\
\text { e95\% ethanol. } \\
{ }^{f} \text { Dose-related trend; }\end{array}$ & $\begin{array}{l}\mathrm{d} \text { at ILS } \\
\mathrm{c} \text { erythr } \\
\text { or. } \\
\text { of } 6.2 \\
0 \% \text { (ne } \\
\text { at } \mathrm{P} \leq \\
\text { n with t } \\
\text { unn's t } \\
\text { with t }\end{array}$ & $\begin{array}{l}\text { Inc. The detaile } \\
\text { cyte; NCE }=\text { nol } \\
\%, 12.5 \%, 25 \% \text {, } \\
\text { t) group with the } \\
.05 \text { by Williams } \\
\text { e vehicle contro } \\
\text { st }(6.25 \%, 12.5 \% \\
\text { e untreated contr } \\
\text { nt at } \mathrm{P} \leq 0.025 \mathrm{~b}\end{array}$ & $\begin{array}{l}\text { protocol is presente } \\
\text { mochromatic erythro } \\
\text { and } 50 \% \text { groups with } \\
\text { untreated control gro } \\
\text { test. } \\
\text { group, values are sig } \\
25 \% \text {, and } 50 \% \text { fem } \\
\text { group, values are s } \\
\text { linear regression. }\end{array}$ & $\begin{array}{l}\mathrm{d} \text { by Dert } \\
\text { cyte. } \\
\text { the vehi } \\
\text { up or vel } \\
\text { nificant a } \\
\text { ales); } 100 \\
\text { ignifican }\end{array}$ & $\begin{array}{l}\text { nger et al. }{ }^{54} \text {, MacG } \\
\text { le control group, va } \\
\text { icle control group } \\
P \leq 0.025 \text { by Will } \\
\% \text { (neat) group witl } \\
\text { at } P \leq 0.05 \text { by Will }\end{array}$ & $\begin{array}{l}\text { egor et al. } \\
\text { ues are si } \\
\text { ith the unt } \\
\text { ims' test ( } \\
\text { the untrea } \\
\text { ams' test. }\end{array}$ & $\begin{array}{l}5 \text {, and Witt et } \\
\text { nificant at } \mathrm{P} \\
\text { reated control } \\
.25 \%, 12.5 \% \\
\text { ted control grc }\end{array}$ & $\begin{array}{l}\text { al. } \\
\text { a6. } \\
\text { group, } \\
25 \% \text {, } \\
\text { up or }\end{array}$ \\
\hline
\end{tabular}


OTNE, TOX 92

Table E-4. Frequency of Micronuclei in Peripheral Blood Erythrocytes of Mice Following Dermal Application of OTNE for Three Months ${ }^{\mathrm{a}}$

\begin{tabular}{|c|c|c|c|c|c|c|c|c|}
\hline & $\begin{array}{c}\text { Dose } \\
(\%)\end{array}$ & $\begin{array}{l}\text { Number of } \\
\text { Mice with } \\
\text { Erythrocytes } \\
\text { Scored }\end{array}$ & $\begin{array}{l}\text { Micronucleated } \\
\text { PCEs/1,000 } \\
\text { PCEs }^{\mathbf{b}}\end{array}$ & $\begin{array}{c}\text { P } \\
\text { Value }^{c}\end{array}$ & $\begin{array}{l}\text { Micronucleated } \\
\text { NCEs/1,000 } \\
\text { NCEs }\end{array}$ & $\begin{array}{c}\text { P } \\
\text { Value }^{\mathbf{c}}\end{array}$ & $\operatorname{PCEs}^{\mathrm{b}}(\%)$ & $\begin{array}{c}P \\
\text { Value }^{c}\end{array}$ \\
\hline \multicolumn{9}{|l|}{ Male } \\
\hline Vehicle control $^{\mathrm{d}}$ & 0 & 5 & $2.42 \pm 0.16$ & & $1.47 \pm 0.02$ & & $1.46 \pm 0.08$ & \\
\hline \multirow[t]{5}{*}{ OTNE } & 6.25 & 5 & $2.55 \pm 0.24$ & 0.397 & $1.48 \pm 0.04$ & 0.703 & $1.52 \pm 0.12$ & 0.620 \\
\hline & 12.5 & 5 & $2.78 \pm 0.30$ & 0.471 & $1.43 \pm 0.04$ & 0.787 & $1.58 \pm 0.08$ & 0.651 \\
\hline & 25 & 5 & $2.43 \pm 0.20$ & 0.501 & $1.39 \pm 0.05$ & 0.820 & $1.52 \pm 0.04$ & 0.695 \\
\hline & 50 & 5 & $2.24 \pm 0.14$ & 0.518 & $1.49 \pm 0.02$ & 0.477 & $1.47 \pm 0.05$ & 0.717 \\
\hline & & & $\mathrm{P}=0.865^{\mathrm{e}}$ & & $P=0.442$ & & $\mathrm{P}=0.851$ & \\
\hline Untreated control & & 5 & $2.66 \pm 0.14$ & & $1.45 \pm 0.02$ & & $1.60 \pm 0.06$ & \\
\hline OTNE & 100 & 5 & $2.29 \pm 0.15$ & 0.805 & $1.59 \pm 0.03$ & 0.001 & $2.00 \pm 0.20$ & 0.066 \\
\hline Untreated control & & 5 & $2.66 \pm 0.14$ & & $1.45 \pm 0.02$ & & $1.60 \pm 0.59$ & \\
\hline Vehicle control & 0 & 5 & $2.42 \pm 0.16$ & 0.707 & $1.47 \pm 0.02$ & 0.235 & $1.46 \pm 0.08$ & 0.190 \\
\hline \multicolumn{9}{|l|}{ Female } \\
\hline Vehicle control & 0 & 5 & $2.13 \pm 0.12$ & & $1.01 \pm 0.02$ & & $1.52 \pm 0.12$ & \\
\hline \multirow[t]{5}{*}{ OTNE } & 6.25 & 5 & $1.76 \pm 0.10$ & 0.877 & $1.01 \pm 0.02$ & 0.472 & $1.51 \pm 0.09$ & 1.000 \\
\hline & 12.5 & 5 & $2.15 \pm 0.05$ & 0.887 & $1.07 \pm 0.04$ & 0.064 & $2.06 \pm 0.13$ & 0.053 \\
\hline & 25 & 5 & $1.95 \pm 0.14$ & 0.912 & $1.08 \pm 0.02$ & 0.039 & $1.84 \pm 0.21$ & 0.056 \\
\hline & 50 & 5 & $1.85 \pm 0.12$ & 0.924 & $1.15 \pm 0.01$ & 0.001 & $1.96 \pm 0.14$ & 0.045 \\
\hline & & & $P=0.856$ & & $\mathrm{P}<0.001$ & & $P=0.050$ & \\
\hline Untreated control & & 5 & $1.98 \pm 0.14$ & & $1.03 \pm 0.04$ & & $1.08 \pm 0.15$ & \\
\hline OTNE & 100 & 5 & $2.88 \pm 0.23$ & 0.005 & $1.27 \pm 0.01$ & $<0.001$ & $1.89 \pm 0.25$ & 0.031 \\
\hline Untreated control & & 5 & $1.98 \pm 0.14$ & & $1.03 \pm 0.04$ & & $1.08 \pm 0.15$ & \\
\hline Vehicle control & 0 & 5 & $2.13 \pm 0.12$ & 0.230 & $1.01 \pm 0.02$ & 0.581 & $1.52 \pm 0.12$ & 0.048 \\
\hline \multicolumn{9}{|c|}{$\begin{array}{l}\text { 'Pairwise comparison of } 6.25 \%, 12.5 \%, 25 \% \text {, and } 50 \% \text { groups with the vehicle control group, values are significant at } \mathrm{P} \leq 0.025 \\
\text { by Williams' test; } 100 \% \text { (neat) group with the untreated control group or vehicle control group with the untreated control group, } \\
\text { values are significant at } \mathrm{P} \leq 0.05 \text { by Williams' test. } \\
\text { d95\% ethanol. }\end{array}$} \\
\hline
\end{tabular}


OTNE, TOX 92

\section{Appendix F. Chemical Characterization and Dose Formulation Studies}

\section{Table of Contents}

F.1. Procurement and Characterization

F-2

F.2. Preparation and Analysis of Dose Formulations

\section{Tables}

Table F-1. Preparation and Storage of Dose Formulations in the Three-month Dermal

Studies of OTNE

Table F-2. Results of Analyses of Dose Formulations Administered to Rats and Mice in the Three-month Dermal Studies of OTNE.

\section{Figures}

Figure F-1. Infrared Absorption Spectrum of OTNE

Figure F-2. Proton Nuclear Magnetic Resonance Spectrum of OTNE 
OTNE, TOX 92

\section{F.1. Procurement and Characterization}

\section{F.1.1. OTNE}

OTNE (octahydro-tetramethyl-naphthalenyl-ethanone) was obtained as Iso-E Super ${ }^{\circledR}$ from International Flavors and Fragrances, Inc. (Ringwood, NJ), in one lot (RAV0276433) that was used in the 3-month dermal studies. Identity and purity analyses were conducted by the analytical chemistry laboratory at Research Triangle Institute (Research Triangle Park, NC), and purity analyses were conducted by the study laboratory at BioReliance Corporation (Rockville, MD). Reports on analyses performed in support of the OTNE studies are on file at the National Institute of Environmental Health Sciences.

The test article, a colorless to pale-yellow liquid, was identified as OTNE by the analytical chemistry laboratory using infrared (IR) and proton nuclear magnetic resonance (NMR) spectrometry and gas chromatography (GC) with mass spectrometry (MS) detection. All spectra were consistent with the structure of OTNE isomers. Representative IR and NMR spectra are presented in Figure F-1 and Figure F-2, respectively.

The purity of the test chemical was determined by the analytical chemistry laboratory using GC with flame ionization detection (FID) and GC/MS. The GC systems included a gas chromatagraph (Hewlett-Packard, Palo Alto, CA), an Equity ${ }^{\circledR}-5,30 \mathrm{~m} \times 0.32 \mathrm{~mm}, 0.25 \mu \mathrm{m}$ film (Supelco, Inc., Bellefonte, PA) column, an oven temperature program of $60^{\circ} \mathrm{C}$ for 20 minutes, then $10^{\circ} \mathrm{C} /$ minute to $200^{\circ} \mathrm{C}$, held for 26 minutes, helium carrier gas at a flow rate of 1 or $2 \mathrm{~mL} / \mathrm{minute}$, with flame ionization or mass spectrometry (Agilent Technologies, Santa Clara, CA) detection.

GC/FID analysis indicated four major peaks and nine minor peaks; each of the minor peaks was less than $1 \%$ of the total peak area. GC/MS analysis indicated mass spectra for the major peaks that were very similar, showing the same fragments with slight variations in relative abundance: These were tentatively identified as $\beta$-isomer, $\alpha$-isomer, $\gamma$-isomer, and $1-(1,2,3,4,5,6,7,8$ octahydro-2,3,5,5-tetramethyl-2-naphthalenyl)ethanone based on the spectra and comparison to the literature ${ }^{36}$. The overall purity of lot RAV0276433 was estimated to be greater than $96 \%$ relative to the four OTNE isomers: $\beta$-isomer (56.6\%), $\alpha$-isomer $(18.0 \%), \gamma$-isomer $(17.7 \%)$, and 1-(1,2,3,4,5,6,7,8-octahydro-2,3,5,5-tetramethyl-2-naphthalenyl)ethenone (3.9\%).

To ensure stability, the test chemical was stored in sealed amber glass vials at room temperature under a desiccant. Reanalysis of the test chemical was performed at the end of the study by the study laboratory using GC/FID by a method similar to that described previously; no degradation of the test chemical was detected.

\section{F.1.2. Ethanol}

USP-grade 95\% ethanol was obtained from Pharmco Products, Inc. (Brookfield, CT), in one lot (M0000) that was used as the vehicle in the 3-month dermal studies.

\section{F.2. Preparation and Analysis of Dose Formulations}

Except for the $100 \%$ dose formulations, which were used neat, the dose formulations were prepared by mixing OTNE with $95 \%$ ethanol to give the required concentrations and stirring 
OTNE, TOX 92

with a magnetic stir bar for at least 15 minutes (Table F-1). The dose formulations were stored in a flammable chemical storage cabinet in amber glass bottles sealed with Teflon ${ }^{\circledR}$ silicone septa and an aluminum crimp seal under a nitrogen headspace at room temperature $\left(\sim 25^{\circ} \mathrm{C}\right)$. The dose formulations were prepared three times during the 3-month studies.

Stability studies of $12.5 \%$ in $95 \%$ ethanol formulations made with lot RAV0276433 were performed by the analytical chemistry laboratory using GC/FID by a method similar to that described previously. Stability was confirmed for at least 42 days at ambient temperatures and for at least 3 hours under simulated animal room conditions.

The dose formulations were analyzed three times by the study laboratory using GC/FID by a system similar to that previously described. All 30 of the dose formulations analyzed for rats and mice were within $10 \%$ of the target concentrations (Table F-2). Animal room samples of these dose formulations were also analyzed; 28 of 30 for rats and 26 of 30 for mice were within $10 \%$ of the target concentrations.

Table F-1. Preparation and Storage of Dose Formulations in the Three-month Dermal Studies of OTNE

\section{Three-month Dermal Study}

\section{Preparation}

Except for the $100 \%$ (neat) dose, the dose formulations were prepared by mixing OTNE with $95 \%$ ethanol to give the required concentrations and stirred with a magnetic stir bar for at least 15 minutes. The dose formulations were prepared three times during the 3-month studies.

\section{Chemical Lot Number}

RAV0276433

Maximum Storage Time

42 days

\section{Storage Conditions}

The dose formulations were stored in a flammable storage cabinet in amber glass bottles sealed with Teflon ${ }^{\circledR}$ silicone septa and an aluminum crimp seal under a nitrogen headspace at room temperature $\left(\sim 25^{\circ} \mathrm{C}\right)$.

\section{Study Laboratory}

BioReliance Corporation (Rockville, MD) 
OTNE, TOX 92

Table F-2. Results of Analyses of Dose Formulations Administered to Rats and Mice in the Threemonth Dermal Studies of OTNE

\begin{tabular}{|c|c|c|c|c|}
\hline Date Prepared & Date Analyzed & $\begin{array}{c}\text { Target } \\
\text { Concentration }(\% \mathrm{v} / \mathrm{v})\end{array}$ & $\begin{array}{c}\text { Determined } \\
\text { Concentrationa }(\% \text { v/v })\end{array}$ & $\begin{array}{c}\text { Difference from } \\
\text { Target }(\%)\end{array}$ \\
\hline \multirow[t]{30}{*}{ December 5, 2006} & December 6, 2006 & 6.25 & 6.48 & +4 \\
\hline & & 6.25 & 6.56 & +5 \\
\hline & & 12.5 & 12.2 & -2 \\
\hline & & 12.5 & 12.6 & +1 \\
\hline & & 25 & 25.5 & +2 \\
\hline & & 25 & 24.8 & -1 \\
\hline & & 50 & 48.8 & -2 \\
\hline & & 50 & 52.0 & +4 \\
\hline & & 100 & 102 & +2 \\
\hline & & 100 & 104 & +4 \\
\hline & January $21,2007^{\mathrm{b}}$ & 6.25 & 6.13 & -2 \\
\hline & & 6.25 & 6.27 & 0 \\
\hline & & 12.5 & 12.4 & -1 \\
\hline & & 12.5 & 12.1 & -3 \\
\hline & & 25 & 24.7 & -1 \\
\hline & & 25 & 24.8 & -1 \\
\hline & & 50 & 49.7 & -1 \\
\hline & & 50 & 49.0 & -2 \\
\hline & & 100 & 104 & +4 \\
\hline & & 100 & 102 & +2 \\
\hline & January $29,2007^{c}$ & 6.25 & 8.45 & +35 \\
\hline & & 6.25 & 8.66 & +39 \\
\hline & & 12.5 & 12.7 & +2 \\
\hline & & 12.5 & 12.9 & +3 \\
\hline & & 25 & 27.2 & +9 \\
\hline & & 25 & 27.1 & +8 \\
\hline & & 50 & 57.2 & +14 \\
\hline & & 50 & 54.9 & +10 \\
\hline & & 100 & 99.4 & -1 \\
\hline & & 100 & 98.4 & -2 \\
\hline \multirow[t]{3}{*}{ January 2, 2007} & January 2, 2007 & 6.25 & 6.47 & +4 \\
\hline & & 6.25 & 6.42 & +3 \\
\hline & & 12.5 & 12.4 & -1 \\
\hline
\end{tabular}


OTNE, TOX 92

\begin{tabular}{|c|c|c|c|c|}
\hline Date Prepared & Date Analyzed & $\begin{array}{c}\text { Target } \\
\text { Concentration }(\% \mathrm{v} / \mathrm{v})\end{array}$ & $\begin{array}{c}\text { Determined } \\
\text { Concentrationa }(\% \mathrm{v} / \mathrm{v})\end{array}$ & $\begin{array}{l}\text { Difference from } \\
\text { Target }(\%)\end{array}$ \\
\hline & & 12.5 & 12.4 & -1 \\
\hline & & 25 & 24.8 & -1 \\
\hline & & 25 & 24.7 & -1 \\
\hline & & 50 & 49.0 & -2 \\
\hline & & 50 & 48.8 & -2 \\
\hline & & 100 & 97.1 & -3 \\
\hline & & 100 & 96.9 & -3 \\
\hline & February $15,2007^{\mathrm{b}}$ & 6.25 & 6.80 & +9 \\
\hline & & 6.25 & 6.94 & +11 \\
\hline & & 12.5 & 12.7 & +2 \\
\hline & & 12.5 & 12.9 & +3 \\
\hline & & 25 & 26.7 & +7 \\
\hline & & 25 & 29.0 & +16 \\
\hline & & 50 & 50.5 & +1 \\
\hline & & 50 & 51.8 & +4 \\
\hline & & 100 & 101 & +1 \\
\hline & & 100 & 103 & +3 \\
\hline & February $15,2007^{c}$ & 6.25 & 6.90 & +10 \\
\hline & & 6.25 & 6.90 & +10 \\
\hline & & 12.5 & 13.0 & +4 \\
\hline & & 12.5 & 13.3 & +6 \\
\hline & & 25 & 29.4 & +18 \\
\hline & & 25 & 27.4 & +10 \\
\hline & & 50 & 51.5 & +3 \\
\hline & & 50 & 53.5 & +7 \\
\hline & & 100 & 100 & 0 \\
\hline & & 100 & 101 & +1 \\
\hline \multirow[t]{8}{*}{ February 2, 2007} & February 6, 2007 & 6.25 & 6.33 & +1 \\
\hline & & 6.25 & 6.16 & -1 \\
\hline & & 12.5 & 12.4 & -1 \\
\hline & & 12.5 & 12.5 & 0 \\
\hline & & 25 & 24.9 & 0 \\
\hline & & 25 & 25.0 & 0 \\
\hline & & 50 & 48.9 & -2 \\
\hline & & 50 & 49.9 & 0 \\
\hline
\end{tabular}


OTNE, TOX 92

\begin{tabular}{|c|c|c|c|c|}
\hline Date Prepared & Date Analyzed & $\begin{array}{c}\text { Target } \\
\text { Concentration }(\% \mathrm{v} / \mathrm{v})\end{array}$ & $\begin{array}{c}\text { Determined } \\
\text { Concentrationa }(\% \mathrm{v} / \mathrm{v})\end{array}$ & $\begin{array}{l}\text { Difference from } \\
\text { Target }(\%)\end{array}$ \\
\hline & \multirow{6}{*}{ March $20,2007^{\mathrm{b}}$} & 100 & 100.8 & +1 \\
\hline & & 100 & 101.3 & +1 \\
\hline & & 6.25 & 6.43 & +3 \\
\hline & & 6.25 & 6.61 & +6 \\
\hline & & 12.5 & 12.8 & +2 \\
\hline & & 12.5 & 12.6 & +1 \\
\hline & \multirow{16}{*}{ March 20, 2007c } & 25 & 25.0 & 0 \\
\hline & & 25 & 25.2 & +1 \\
\hline & & 50 & 51.0 & +2 \\
\hline & & 50 & 51.4 & +3 \\
\hline & & 100 & 102 & -2 \\
\hline & & 100 & 99 & -1 \\
\hline & & 6.25 & 6.49 & +4 \\
\hline & & 6.25 & 6.63 & +6 \\
\hline & & 12.5 & 12.9 & +3 \\
\hline & & 12.5 & 12.8 & +2 \\
\hline & & 25 & 25.6 & +2 \\
\hline & & 25 & 25.5 & +2 \\
\hline & & 50 & 52.1 & +4 \\
\hline & & 50 & 51.3 & +3 \\
\hline & & 100 & 100 & 0 \\
\hline & & 100 & 101 & +1 \\
\hline
\end{tabular}

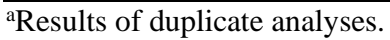

${ }^{\mathrm{b}}$ Animal room samples for rats.

${ }^{\mathrm{c} A n i m a l ~ r o o m ~ s a m p l e s ~ f o r ~ m i c e . ~}$ 
OTNE, TOX 92

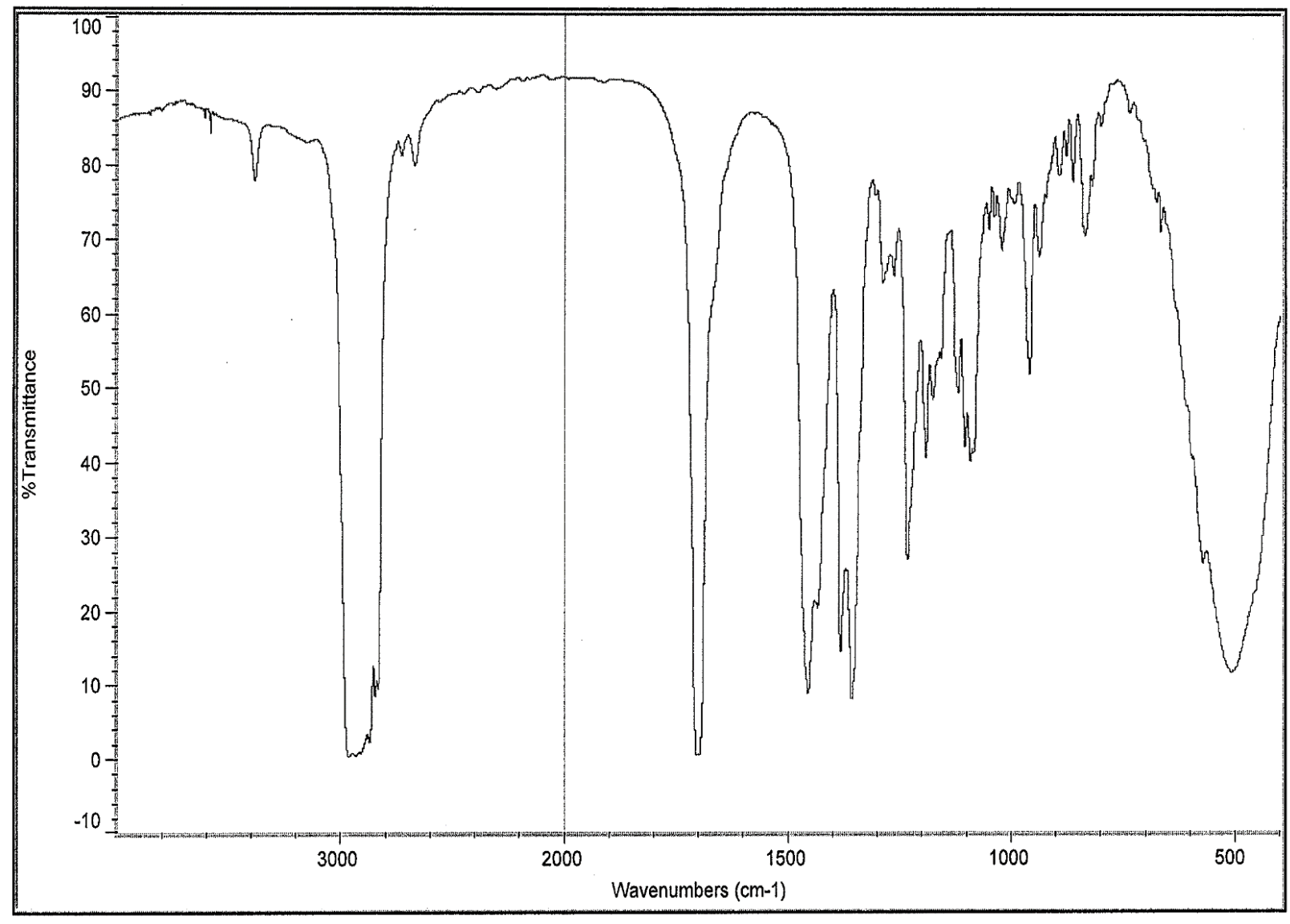

Figure F-1. Infrared Absorption Spectrum of OTNE 
OTNE, TOX 92

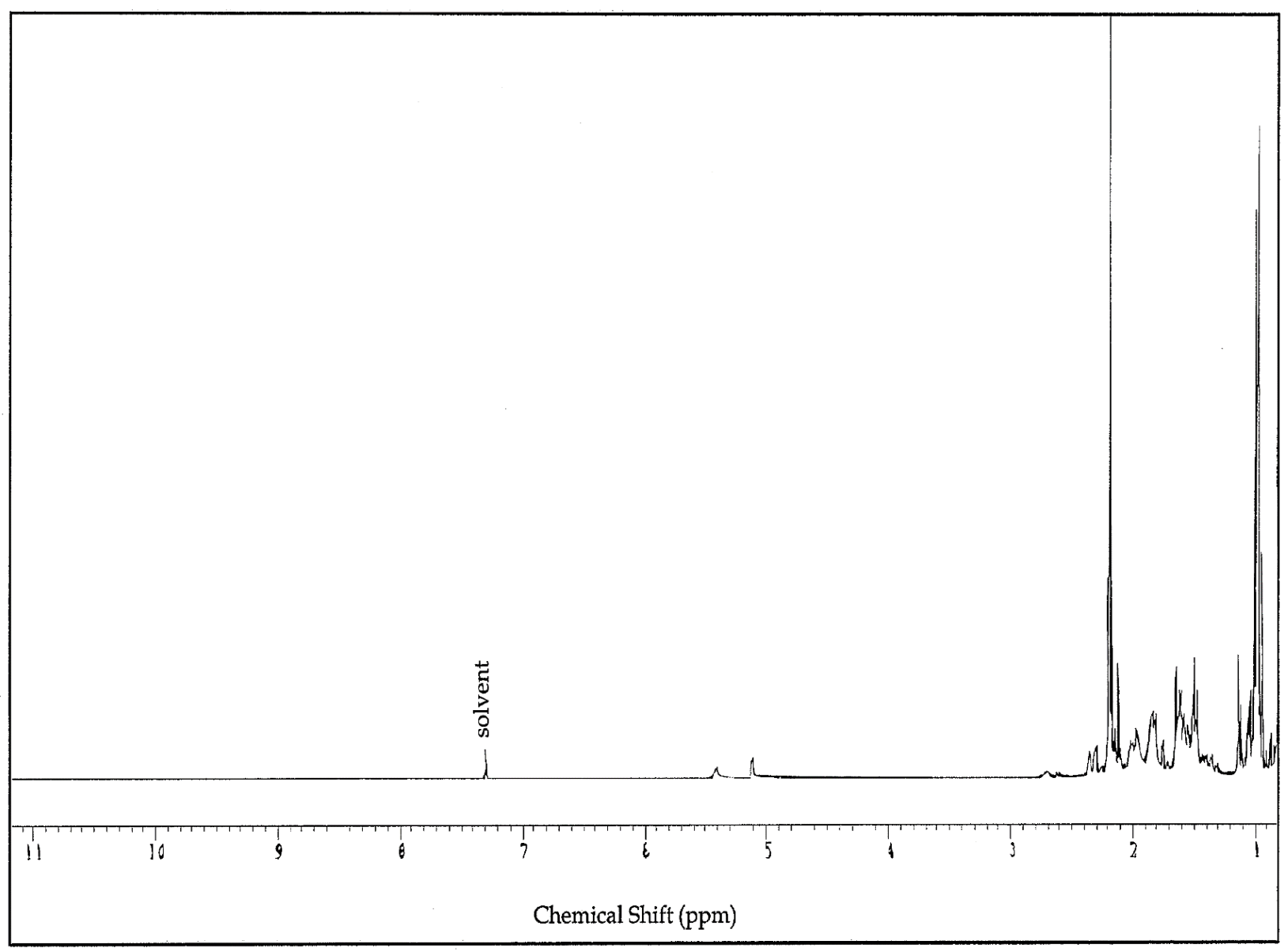

Figure F-2. Proton Nuclear Magnetic Resonance Spectrum of OTNE 
OTNE, TOX 92

\section{Appendix G. Ingredients, Nutrient Composition, and Contaminant Levels in NTP-2000 Rat and Mouse Ration}

\section{Tables}

Table G-1. Ingredients of NTP-2000 Rat and Mouse Ration G-2

Table G-2. Vitamins and Minerals in NTP-2000 Rat and Mouse Ration. G-2

Table G-3. Nutrient Composition of NTP-2000 Rat and Mouse Ration G-4

Table G-4. Contaminant Levels in NTP-2000 Rat and Mouse Ration G-6 
OTNE, TOX 92

Table G-1. Ingredients of NTP-2000 Rat and Mouse Ration

\begin{tabular}{lc}
\hline \multicolumn{1}{c}{ Ingredients } & Percent by Weight \\
\hline Ground hard winter wheat & 22.26 \\
Ground \#2 yellow shelled corn & 22.18 \\
Wheat middlings & 15.0 \\
Oat hulls & 8.5 \\
Alfalfa meal (dehydrated, 17\% protein) & 7.5 \\
Purified cellulose & 5.5 \\
Soybean meal (49\% protein) & 5.0 \\
Fish meal (60\% protein) & 4.0 \\
Corn oil (without preservatives) & 3.0 \\
Soy oil (without preservatives) & 3.0 \\
Dried brewer's yeast & 1.0 \\
Calcium carbonate (USP) & 0.9 \\
Vitamin premix & \\
Mineral premix & \\
Calcium phosphate, dibasic (USP) & 0.5 \\
Sodium chloride & 0.5 \\
Choline chloride (70\% choline) & 0.4 \\
Methionine & 0.3 \\
\hline W & 0.26 \\
\hline
\end{tabular}

${ }^{\text {aWheat middlings as carrier. }}$

${ }^{\mathrm{b}}$ Calcium carbonate as carrier.

Table G-2. Vitamins and Minerals in NTP-2000 Rat and Mouse Ration ${ }^{\mathrm{a}}$

\begin{tabular}{lcl}
\hline & Amount & Source \\
\hline Vitamins & & \\
$\mathrm{A}$ & $4,000 \mathrm{IU}$ & Stabilized vitamin A palmitate or acetate \\
$\mathrm{D}$ & $1,000 \mathrm{IU}$ & D-activated animal sterol \\
$\mathrm{K}$ & $1.0 \mathrm{mg}$ & Menadione sodium bisulfite complex \\
$\alpha$-Tocopheryl acetate & $100 \mathrm{IU}$ & - \\
Niacin & $23 \mathrm{mg}$ & - \\
Folic acid & $1.1 \mathrm{mg}$ & - \\
$d$-Pantothenic acid & $10 \mathrm{mg}$ & $d$-Calcium pantothenate \\
Riboflavin & $3.3 \mathrm{mg}$ & - \\
Thiamine & $4 \mathrm{mg}$ & Thiamine mononitrate \\
B 12 & $52 \mu \mathrm{g}$ & - \\
Pyridoxine & $6.3 \mathrm{mg}$ & Pyridoxine hydrochloride \\
Biotin & $0.2 \mathrm{mg}$ & $d$-Biotin \\
\hline
\end{tabular}


OTNE, TOX 92

\begin{tabular}{lcl}
\hline & Amount & \multicolumn{1}{c}{ Source } \\
\hline Minerals & & \\
Magnesium & $514 \mathrm{mg}$ & Magnesium oxide \\
Iron & $35 \mathrm{mg}$ & Iron sulfate \\
Zinc & $12 \mathrm{mg}$ & Zinc oxide \\
Manganese & $10 \mathrm{mg}$ & Manganese oxide \\
Copper & $2.0 \mathrm{mg}$ & Copper sulfate \\
Iodine & $0.2 \mathrm{mg}$ & Calcium iodate \\
Chromium & $0.2 \mathrm{mg}$ & Chromium acetate \\
\hline
\end{tabular}

${ }^{\mathrm{a} P e r ~ k g}$ of finished product. 
OTNE, TOX 92

Table G-3. Nutrient Composition of NTP-2000 Rat and Mouse Ration

\begin{tabular}{|c|c|c|c|}
\hline Nutrient & $\begin{array}{c}\text { Mean } \pm \text { Standard } \\
\text { Deviation }\end{array}$ & Range & Number of Samples \\
\hline Protein (\% by weight) & $14.6 \pm 0.40$ & $14.2-15.0$ & 3 \\
\hline Crude fat ( $\%$ by weight) & $8.1 \pm 0.29$ & $7.8-8.3$ & 3 \\
\hline Crude fiber ( $\%$ by weight) & $8.8 \pm 0.52$ & $8.5-9.4$ & 3 \\
\hline Ash (\% by weight) & $4.7 \pm 0.23$ & $4.4-4.8$ & 3 \\
\hline \multicolumn{4}{|c|}{ Amino Acids ( $\%$ of total diet) } \\
\hline Arginine & $0.783 \pm 0.070$ & $0.670-0.970$ & 22 \\
\hline Cystine & $0.220 \pm 0.024$ & $0.150-0.250$ & 22 \\
\hline Glycine & $0.701 \pm 0.041$ & $0.620-0.800$ & 22 \\
\hline Histidine & $0.352 \pm 0.077$ & $0.270-0.680$ & 22 \\
\hline Isoleucine & $0.546 \pm 0.044$ & $0.430-0.660$ & 22 \\
\hline Leucine & $1.095 \pm 0.067$ & $0.960-1.240$ & 22 \\
\hline Lysine & $0.711 \pm 0.114$ & $0.310-0.860$ & 22 \\
\hline Methionine & $0.409 \pm 0.046$ & $0.260-0.490$ & 22 \\
\hline Phenylalanine & $0.628 \pm 0.040$ & $0.540-0.720$ & 22 \\
\hline Threonine & $0.505 \pm 0.043$ & $0.430-0.610$ & 22 \\
\hline Tryptophan & $0.150 \pm 0.028$ & $0.110-0.200$ & 22 \\
\hline Tyrosine & $0.401 \pm 0.061$ & $0.280-0.540$ & 22 \\
\hline Valine & $0.665 \pm 0.043$ & $0.550-0.730$ & 22 \\
\hline \multicolumn{4}{|c|}{ Essential Fatty Acids (\% of total diet) } \\
\hline Linoleic & $3.95 \pm 0.259$ & $3.49-4.55$ & 22 \\
\hline Linolenic & $0.30 \pm 0.032$ & $0.21-0.35$ & 22 \\
\hline \multicolumn{4}{|l|}{ Vitamins } \\
\hline Vitamin A (IU/kg) & $3,560 \pm 53.5$ & $2,950-3,950$ & 3 \\
\hline Vitamin D (IU/kg) & $1,000^{\mathrm{a}}$ & - & - \\
\hline$\alpha$-Tocopherol (ppm) & $80.6 \pm 22.03$ & $27.0-124.0$ & 22 \\
\hline Thiamine $(\mathrm{ppm})^{\mathrm{b}}$ & $7.7 \pm 0.89$ & $7.0-8.7$ & 22 \\
\hline Riboflavin (ppm) & $7.6 \pm 2.89$ & $4.20-17.50$ & 22 \\
\hline Niacin (ppm) & $78.9 \pm 9.08$ & $66.4-98.2$ & 22 \\
\hline Pantothenic acid (ppm) & $26.9 \pm 12.63$ & $17.4-81.0$ & 22 \\
\hline Pyridoxine $(\mathrm{ppm})^{\mathrm{b}}$ & $9.54 \pm 1.99$ & $6.44-13.7$ & 22 \\
\hline Folic acid (ppm) & $1.62 \pm 0.48$ & $1.15-3.27$ & 22 \\
\hline Biotin (ppm) & $0.32 \pm 0.10$ & $0.20-0.704$ & 22 \\
\hline Vitamin $B_{12}(p p b)$ & $53.6 \pm 39.6$ & $18.3-174.0$ & 22 \\
\hline Choline (ppm) ${ }^{\mathrm{b}}$ & $2,846 \pm 485$ & $1,820-3,790$ & 22 \\
\hline
\end{tabular}


OTNE, TOX 92

\begin{tabular}{lccc}
\hline \multicolumn{1}{c}{ Nutrient } & $\begin{array}{c}\text { Mean } \pm \text { Standard } \\
\text { Deviation }\end{array}$ & Range & Number of Samples \\
\hline Minerals & $0.888 \pm 0.028)$ & $0.865-0.919$ & 3 \\
Calcium (\%) & $0.532 \pm 0.018)$ & $0.516-0.552$ & 3 \\
Phosphorus (\%) & $0.666 \pm 0.030)$ & $0.626-0.733$ & 22 \\
Potassium (\%) & $0.386 \pm 0.039$ & $0.300-0.474$ & 22 \\
Chloride (\%) & $0.189 \pm 0.016$ & $0.160-0.222$ & 22 \\
Sodium (\%) & $0.216 \pm 0.062$ & $0.185-0.490$ & 22 \\
Magnesium (\%) & $0.170 \pm 0.029$ & $0.116-0.209$ & 22 \\
Sulfur (\%) & $186 \pm 9.2$ & $135-311$ & 22 \\
Iron (ppm) & $51.4 \pm 10.28$ & $21.0-73.1$ & 22 \\
Manganese (ppm) & $53.4 \pm 8.46$ & $43.3-78.5$ & 22 \\
Zinc (ppm) & $7.01 \pm 2.562$ & $3.21-16.3$ & 21 \\
Copper (ppm) & $0.503 \pm 0.206$ & $0.158-0.972$ & 20 \\
Iodine (ppm) & $0.694 \pm 0.276$ & $0.330-1.380$ & \\
Chromium (ppm) & $0.256 \pm 0.164$ & $0.098-0.864$ & \\
Cobalt (ppm) & & & 22 \\
\hline
\end{tabular}

${ }^{\mathrm{a} F r o m ~ f o r m u l a t i o n . ~}$

${ }^{\mathrm{b}}$ As hydrochloride (thiamine and pyridoxine) or chloride (choline). 
OTNE, TOX 92

Table G-4. Contaminant Levels in NTP-2000 Rat and Mouse Ration ${ }^{\text {a }}$

\begin{tabular}{|c|c|c|c|}
\hline & $\underset{\text { Deviation }^{\mathrm{b}}}{\operatorname{Mean} \pm \text { Standard }}$ & Range & Number of Samples \\
\hline \multicolumn{4}{|l|}{ Contaminants } \\
\hline Arsenic (ppm) & $0.31 \pm 0.080$ & $0.24-0.40$ & 3 \\
\hline Cadmium (ppm) & $0.06 \pm 0.001$ & $0.06-0.06$ & 3 \\
\hline Lead (ppm) & $0.11 \pm 0.009$ & $0.10-0.12$ & 3 \\
\hline Mercury (ppm) & $<0.02$ & - & 3 \\
\hline Selenium (ppm) & $0.21 \pm 0.041$ & $0.18-0.26$ & 3 \\
\hline Aflatoxins (ppb) & $<5.00$ & - & 3 \\
\hline Nitrate nitrogen $(\mathrm{ppm})^{\mathrm{c}}$ & $10.4 \pm 0.693$ & $10.0-11.2$ & 3 \\
\hline Nitrite nitrogen $(\mathrm{ppm})^{\mathrm{c}}$ & $<0.61$ & - & 3 \\
\hline BHA $(\mathrm{ppm})^{\mathrm{d}}$ & $<1.0$ & - & 3 \\
\hline BHT $(\mathrm{ppm})^{\mathrm{d}}$ & $<1.0$ & - & 3 \\
\hline Aerobic plate count (CFU/g) & $10 \pm 0.0$ & 10 & 3 \\
\hline Coliform (MPN/g) & $3.0 \pm 0.0$ & 3.0 & 3 \\
\hline Escherichia coli (MPN/g) & $<10$ & - & 3 \\
\hline Salmonella (MPN/g) & Negative & - & 3 \\
\hline Total nitrosamines $(\mathrm{ppb})^{\mathrm{e}}$ & $4.4 \pm 3.33$ & $2.0-8.2$ & 3 \\
\hline$N$-Nitrosodimethylamine $(\mathrm{ppb})^{\mathrm{e}}$ & $1.7 \pm 0.61$ & $1.0-2.1$ & 3 \\
\hline$N$-Nitrosopyrrolidine $(\mathrm{ppb})^{\mathrm{e}}$ & $2.7 \pm 2.94$ & $1.0-6.1$ & 3 \\
\hline \multicolumn{4}{|l|}{ Pesticides (ppm) } \\
\hline$\alpha-\mathrm{BHC}$ & $<0.01$ & - & 3 \\
\hline$\beta-\mathrm{BHC}$ & $<0.02$ & - & 3 \\
\hline$\gamma$-BHC & $<0.01$ & - & 3 \\
\hline$\delta$-BHC & $<0.01$ & - & 3 \\
\hline Heptachlor & $<0.01$ & - & 3 \\
\hline Aldrin & $<0.01$ & - & 3 \\
\hline Heptachlor epoxide & $<0.01$ & - & 3 \\
\hline DDE & $<0.01$ & - & 3 \\
\hline DDD & $<0.01$ & - & 3 \\
\hline DDT & $<0.01$ & - & 3 \\
\hline HCB & $<0.01$ & - & 3 \\
\hline Mirex & $<0.01$ & - & 3 \\
\hline Methoxychlor & $<0.05$ & - & 3 \\
\hline Dieldrin & $<0.01$ & - & 3 \\
\hline Endrin & $<0.01$ & - & 3 \\
\hline
\end{tabular}


OTNE, TOX 92

\begin{tabular}{lccc}
\hline & $\begin{array}{c}\text { Mean } \pm \text { Standard } \\
\text { Deviation }\end{array}$ & Range & Number of Samples \\
\hline Telodrin & $<0.01$ & - & 3 \\
Chlordane & $<0.05$ & - & 3 \\
Toxaphene & $<0.10$ & - & 3 \\
Estimated PCBs & $<0.20$ & - & 3 \\
Ronnel & $<0.01$ & - & 3 \\
Ethion & $<0.02$ & - & 3 \\
Trithion & $<0.05$ & - & 3 \\
Diazinon & $<0.10$ & $-020-0.135$ & 3 \\
Methyl chlorpyrifos & $0.075 \pm 0.058$ & - & 3 \\
Methyl parathion & $<0.02$ & - & 3 \\
Ethyl parathion & $<0.02$ & - & 3 \\
Malathion & $0.095 \pm 0.129$ & - & 3 \\
Endosulfan I & $<0.01$ & $-0.20-0.244$ & 3 \\
Endosulfan II & $<0.01$ & -03 & 3 \\
Endosulfan sulfate & & - & 3 \\
\hline
\end{tabular}

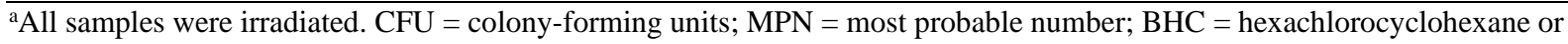
benzene hexachloride.

${ }^{b}$ For values less than the limit of detection, the detection limit is given as the mean.

'Sources of contamination: alfalfa, grains, and fish meal.

${ }^{\mathrm{d} S}$ Sources of contamination: soy oil and fish meal.

${ }^{\mathrm{e}}$ All values were corrected for percent recovery. 
OTNE, TOX 92

\section{Appendix H. Sentinel Animal Program \\ Table of Contents}

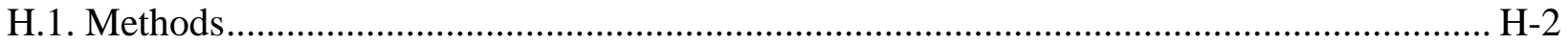

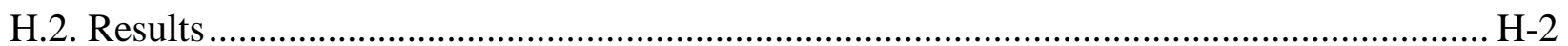

\section{Tables}

Table H-1. Laboratory Methods and Agents Tested for in the Sentinel Animal Program ......... H-2 


\section{H.1. Methods}

Rodents used in the National Toxicology Program are produced in optimally clean facilities to eliminate potential pathogens that may affect study results. The Sentinel Animal Program is part of the periodic monitoring of animal health that occurs during the toxicologic evaluation of test compounds. Under this program, the disease state of the rodents is monitored via sera or feces from extra (sentinel) or dosed animals in the study rooms. The sentinel animals and the study animals are subject to identical environmental conditions. Furthermore, the sentinel animals come from the same production source and weanling groups as the animals used for the studies of test compounds.

In the 3-month studies, blood samples were collected from five male and five female rats and mice at study termination. Blood samples were allowed to clot, and the serum was separated. The serum samples were processed appropriately, sent to BioReliance Corporation (Rockville, MD), and evaluated for the presence of pathogens. The laboratory methods and agents for which testing was performed are tabulated below; the times at which samples were collected during the studies are also listed.

Table H-1. Laboratory Methods and Agents Tested for in the Sentinel Animal Program

\begin{tabular}{ll}
\hline \multicolumn{1}{c}{ Method and Test } & Time of Collection \\
\hline Rats & \\
ELISA & \\
PVM (pneumonia virus of mice) & Study termination \\
RCV/SDA (rat coronavirus/sialodacryoadenitis virus) & Study termination \\
Sendai & Study termination \\
Immunofluorescence Assay & \\
Parvovirus & Study termination \\
\hline Mice & \\
ELISA & \\
Ectromelia virus & Study termination \\
EDIM (epizootic diarrhea of infant mice) & Study termination \\
GDVII (mouse encephalomyelitis virus) & Study termination \\
LCM (lymphocytic choriomeningitis virus) & Study termination \\
MAd-1 (mouse adenoma virus-1) & Study termination \\
MHV (mouse hepatitis virus) & Study termination \\
MMV VP2 (mouse minute virus-viral protein 2) & Study termination \\
MPV VP2 (mouse parvovirus-viral protein 2) & Study termination \\
PVM & Study termination \\
Reovirus & Study termination \\
Sendai & Study termination \\
\hline
\end{tabular}

\section{H.2. Results}

All test results were negative. 


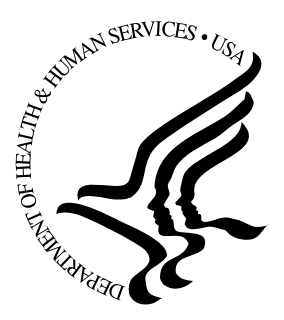

\title{
National Toxicology Program
}

\author{
NTP Central Data Management, MD EC-03
}

National Institute of Environmental Health Sciences

P.O. Box 12233

Research Triangle Park, NC 27709

http://ntp.niehs.nih.gov 